UNIVERSIDADE DE SÃO PAULO

FACULDADE DE EDUCAÇÃO

JULIANA GUERREIRO LICHY CARDOSO

\title{
A Documentação Pedagógica e o Trabalho com Bebês: estudo de caso em uma creche universitária
}





\title{
A documentação pedagógica e o trabalho com bebês: estudo de caso em uma creche universitária
}

\author{
Dissertação apresentada à Faculdade de Educação da \\ Universidade de São Paulo como requisito à obtenção \\ do título de mestre em Educação \\ Linha de pesquisa: Didática, Teoria de Ensino e Práticas \\ Escolares \\ Orientadora: Prof ${ }^{a}$. Dr ${ }^{\mathrm{a}}$. Mônica Appezzato Pinazza
}

\begin{abstract}
VERSÃO CORRIGIDA
A versão original encontra-se disponível na Biblioteca da Unidade e na Biblioteca Digital de Teses e Dissertações da USP
\end{abstract}

São Paulo 
AUTORIZO A REPRODUÇÃO E DIVULGAÇÃO TOTAL OU PARCIAL DESTE TRABALHO, POR QUALQUER MEIO CONVENCIONAL OU ELETRÔNICO, PARA FINS DE ESTUDO E PESQUISA, DESDE QUE CITADA A FONTE.

Catalogação na Publicação

Serviço de Biblioteca e Documentação

Faculdade de Educação da Universidade de São Paulo

371.30 Cardoso, Juliana Guerreiro Lichy

C268d A documentação pedagógica e o trabalho com bebês: estudo de caso em uma creche universitária / Juliana Guerreiro Lichy Cardoso; orientação Mônica Appezzato Pinazza. São Paulo: s.n., 2014.

221 p. ils.; tabs.; anexos; apêndices

Dissertação (Mestrado - Programa de Pós-Graduação em Educação. Área de Concentração: Didática, Teorias de Ensino e Práticas Escolares) - Faculdade de Educação da Universidade de São Paulo.

1. Documentação (Educação; Registro) 2. Prática de ensino 3. Bebês (Educação) 4. Creches I. Pinazza, Mônica Appezzato, orient. 
Nome: CARDOSO, Juliana Guerreiro Lichy

Título: A documentação pedagógica e o trabalho com bebês: estudo de caso em uma creche universitária

Dissertação apresentada à Faculdade de Educação da Universidade de São Paulo como requisito à obtenção do título de mestre em Educação

Aprovado em:

Banca Examinadora

Prof. Dr. Instituição:

Julgamento: Assinatura:

Prof. Dr. Instituição:

Julgamento: Assinatura:

Prof. Dr. Instituição: Assinatura: 

Ao Jorge avô por parte das minhas melhores lembranças da infância. Ao Jorge homem por me ensinar que a sabedoria não está na academia e que a simplicidade é a maior riqueza de um homem. A você meu São Jorge Guerreiro: sempre tão são de si, eternamente Guerreiro. 



\section{AGRADECIMENTOS}

A todos vocês que cruzaram o meu caminho e me ajudaram a constituir-me no que sou, o meu profundo agradecimento:

A Mônica Appezzato Pinazza pelas orientações, pela delicadeza e rigor com que me orientou.

As professoras Maria Clotilde Rossetti-Ferreira e Márcia Gobbi que com suas colocações não tão 'rosas', mas profundamente significativas, contribuíram imensamente para os rumos deste trabalho.

A professora Tizuko Morchida Kishimoto por me iniciar na pesquisa e me abrir caminhos.

Ao Grupo de Pesquisa Contextos Integrados de Educação Infantil pelas oportunidades de aprendizagem em quase dez anos de parceria.

Aos profissionais da creche pesquisada, em especial às três professoras diretamente envolvidas na pesquisa, à coordenadora pedagógica pela receptividade e aos bebês que deram vida ao estudo.

Aos meus pais Rubens e Regina por sempre apostarem em mim e me fazerem acreditar nos sonhos. Em muitos momentos me faltaram palavras para escrever, mas não tanto quanto agora me faltam para expressar a profunda gratidão e orgulho que tenho por tudo que são para mim. Obrigada por mais uma vez serem meu conforto, minha esperança e minha força.

Ao Beto pelo caminho que estamos trilhando juntos e por me fazer sorrir sempre das pequenas coisas da vida. Obrigada pelo amor que me oferece, pelo conforto de seus braços e pelos olhos como me vê.

As minhas irmãs Vanessa e Karol (amadas e amigas) pelo apoio de sempre, pelas conversas e pelas lembranças de tantos momentos juntas. Mesmo longe, o laço que nos une não se rompe jamais.

Aos meus avós pela família que tenho e em especial à minha avó Luzia pela presença em minha vida e por me mostrar tanta força quando as minhas pareciam não mais existir. 
Aos meus sobrinhos amados Isabel, Arthur e Laura por simplesmente existirem e me oferecerem tão de perto momentos únicos de protagonismo infantil. Espero sempre saber escutá-los.

Aos meus familiares que são tantos e imensamente importantes na minha vida. Por fazerem da presença de vocês momentos vitais de respiros e sustentação ao longo do percurso.

As amigas de velhos e novos tempos que acompanham todo meu trajeto: Kátia Nunes, Larissa Neves e Thalyta Petean Selma.

Aos amigos de profissão com quem compartilho alegrias e dilemas do ofício docente desde os tempos de formação: Debora Zemann, Daniela Borracha, Esther Goldeinstein, Luciana Bernardino, Rafael Agena, Flavia Urzua, Melina Tomaz, Mariana Boratino e Ana Carolina Theodoro.

As outras amigas também de profissão, presenças marcantes nas experiências pela educação: Ana Paula Vasco, Cristiane Cardoso, Fernanda Vignola, Ivete Fortunato, Luciana Caserta, Thais Gemignani e Vanessa Almeida.

A Silvia Macul pelos momentos compartilhados, pelos saberes construídos e pelo feliz encontro que tivemos na profissionalidade docente.

A Clélia Cortez, por compartilhar gentilmente toda sua potência e por me ensinar essa generosidade. Obrigada especialmente pela parceria, pelas frutíferas orientações e pela grande diferença que fez em minha trajetória.

A Vania pelas apostas feitas em mim desde muito cedo e pelas portas sempre abertas.

As queridas escolas Criarte e Vera Cruz pelo fértil campo de exercício da profissão ao longo dos anos.

A todas as crianças que cruzaram meu caminho como alunos e fizeram grande parte do que sou como pedagoga.

A Deus e a Nossa Senhora, sobretudo e sempre por me permitirem mais esta realização. 
Minha presença no mundo, com o mundo e com os outros implica o meu conhecimento inteiro de mim mesmo. E quanto melhor me conheça nesta inteireza tanto mais possibilidades terei de, fazendo História, me saber sendo por ela refeito. 



\section{RESUMO}

CARDOSO, Juliana Guerreiro Lichy. A documentação pedagógica e o trabalho com bebês: estudo de caso em uma creche universitária. Mestrado em Educação. São Paulo: Faculdade de Educação da Universidade de São Paulo, 2014.

A relação entre a produção dos registros na educação infantil e o quanto eles se configuram como documentações pedagógicas proporcionando a prática reflexiva e o olhar para os bebês foi o que buscou compreender esta pesquisa. Partindo da concepção de documentação pedagógica defendida pelas pedagogias do norte da Itália e da Associação Criança em Portugal, entende-se que ela é valioso instrumento para professores, crianças e comunidade educativa que, ao partilhar os processos vivenciados do cotidiano das ações pedagógicas, contribui para a postura reflexiva dos professores e a visibilidade das crianças. A investigação de caráter qualitativo configurou-se como um estudo de caso envolvendo três professoras de um agrupamento de berçário de uma creche universitária da cidade de São Paulo. Os dados envolvem essencialmente os registros de caráter pedagógico dessas professoras e o acompanhamento de suas práticas com os bebês. Na busca da compreensão de como os bebês estão evidenciados na prática reflexiva do professor que é instrumentalizada por meio dos registros e da documentação pedagógica buscou-se responder essencialmente a três questões: 1) Como os registros periódicos evidenciam o olhar para os bebês?; 2) Como os registros podem se transformar em documentações pedagógicas com vistas ao planejamento e à avaliação das práticas?; 3) Como as documentações pedagógicas estão a serviço da prática reflexiva do professor? Os dados confirmam uma prática qualificada com bebês, elemento fundamental para que a prática reflexiva aconteça instrumentalizada pelos registros que, por sua vez, se revelam potentes documentações pedagógicas se alcançarem os processos de aprendizagem dos bebês, para além da consecução de produtos estéticos e visuais. A documentação pedagógica pode representar um novo caminho à educação infantil na medida em que possibilita a prática reflexiva do professor e evidencia as crianças no processo educativo, porém os resultados denunciam os escassos espaços e tempos legitimados nas instituições infantis para a reflexão em equipe, além de propor um olhar mais atento à extensa produção de registros, em especial as fotografias, que se constituem arquivos de memória pouco apresentados às crianças e pouco utilizados no âmbito educacional qualitativamente.

Palavras-chave: documentação pedagógica, registro, prática educativa, educação de bebês, creche. 



\begin{abstract}
CARDOSO, Juliana Guerreiro Lichy. The pedagogical documentation and the work with babies: case study in a university childcare center. Master in Education. São Paulo: Faculty of Education of the Universidade de São Paulo, 2014.

The relation between the production of the records in child education and how much they are configured as pedagogical documentation providing the reflexive practice and the look at the babies is what this research intended to understand. From the conception of pedagogical documentation defended by the pedagogies of the North of Italy and the Associação Criança in Portugal, it is understood that it is a valuable tool to teachers, children and the educational community, which, by sharing the everyday processes of pedagogical actions, contributes to the reflexive attitude of teachers and the visibility of the children. The investigation of qualitative type was configured as a case study involving three teachers from a nursery group in a university childcare center at the city of São Paulo. The data involves essentially the records of pedagogical type of these teachers and the monitoring of their practices with the babies. In seeking to understand how the babies are evidenced in the reflexive practice of the teacher that is instrumented through the records and the pedagogical documentation, the intention was to answer three questions essentially: 1) How do the periodic records evince the look at the babies?; 2) How can the records become pedagogical documentation with a view in the planning and evaluation of the practices?; 3) How is the pedagogical documentation at the service of the reflexive practice of the teacher? The data confirm a qualified practice with babies, a fundamental element for the reflexive practice to happen in an exploited way by the registers, which in turn become powerful pedagogical documentation if achieving the learning processes of the babies in addition to the achievement of esthetic and visual products. The pedagogical documentation can represent a new path to the childhood education to the extent that it enables the reflexive practice of the teacher and evidences the children in the educational process, but the results denounce the scarce spaces and legitimized time in the children institutions for the team reflection, besides of proposing a more attentive look to the extensive production of registers, specially photographs, which become memory files that are little presented to the children and little used in the educational field in terms of quality.
\end{abstract}

Key-words: pedagogical documentation, record, educational practice, education of babies, childcare center. 



\section{LISTA DE FIGURAS}

Figura 1 - O processo de documentação pedagógica como ciclo de investigação 61

Figura 2 - Movimentos em espiral entre documentação, interpretação/avaliação, planificação

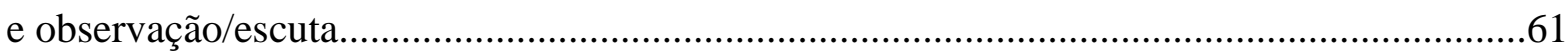

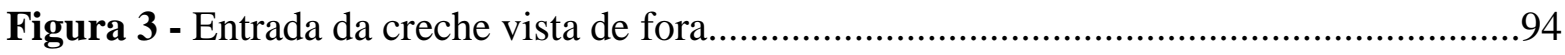

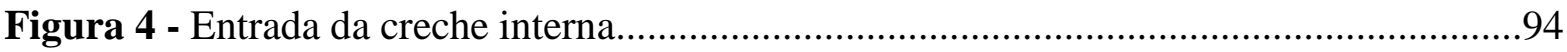

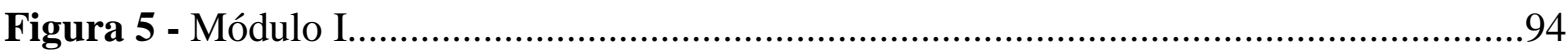

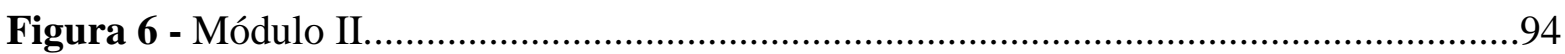

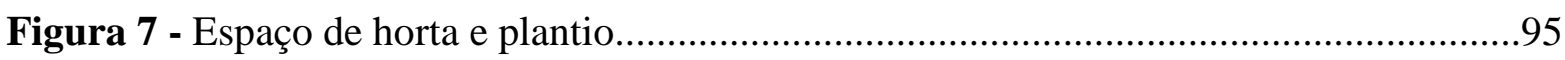

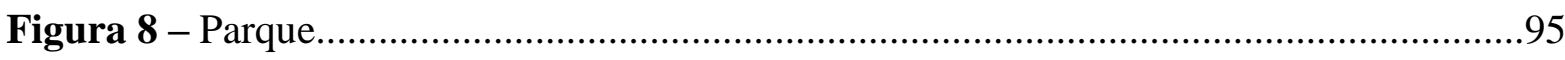

Figura 9 - "Casinha” (sala do berçário)........................................................................115

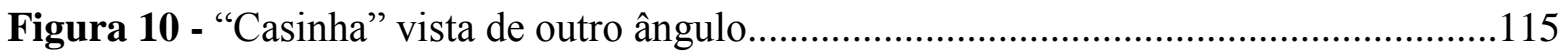

Figura 11 - Área externa saindo da "Casinha" .................................................................115

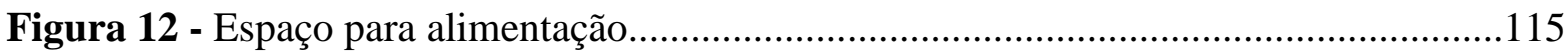

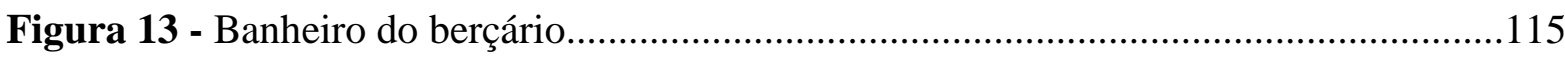

Figura 14 - Painel dos aniversários - Grupo Azul............................................................121

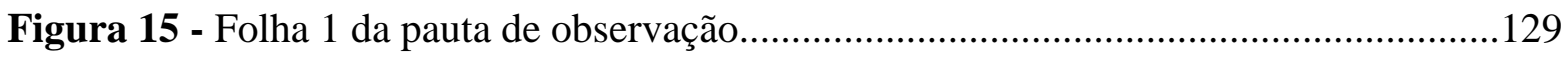

Figura 16 - Folha 2 da pauta de observação...................................................................130

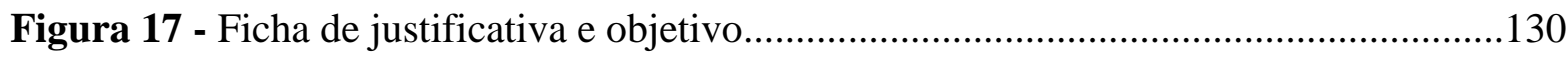

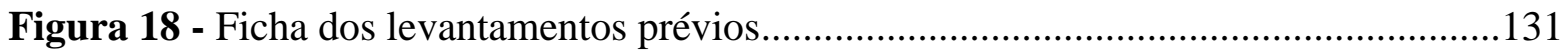

Figura 19 - Ficha da organização inicial do projeto........................................................131 



\section{LISTA DE TABELAS}

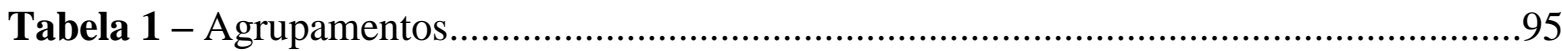

Tabela 2 - Quadro de rotina Módulo I: Grupos Azul, Verde e Amarelo...............................96

Tabela 3 - Síntese das observações realizadas na primeira inserção no campo....................102

Tabela 4 - Síntese das ações durante a inserção no campo (ano de 2012)...........................104

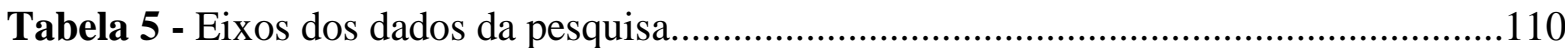





\section{SUMÁRIO}

1. INTRODUÇÃ

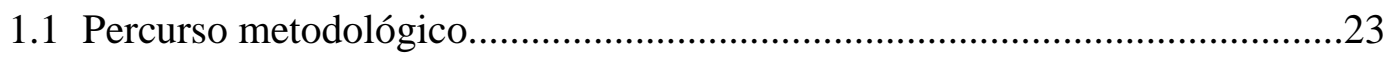

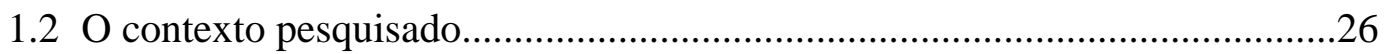

1.2.1 A chegada de Caetano: um convite a entrar na creche........................26

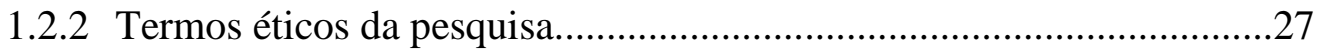

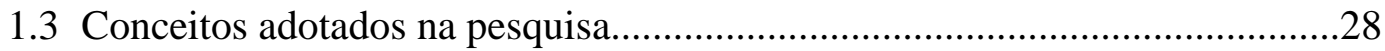

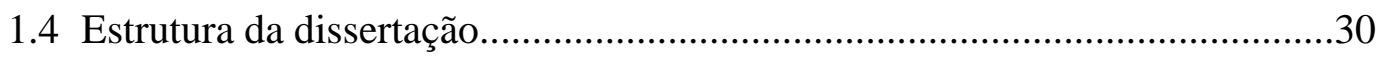

2. SOBRE O TERMO DOCUMENTO: ENTRE MONUMENTO, FONTE DOCUMENTAL E MEMÓRIA.

3. BASES DA DOCUMENTAÇÃO PEDAGÓGICA: A PRÁTICA REFLEXIVA A PARTIR DOS REGISTROS

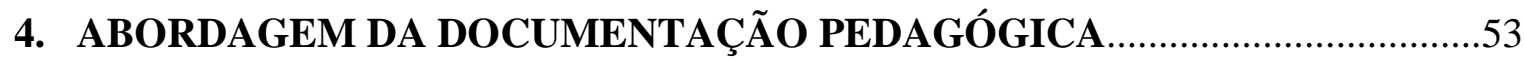

4.1 Documentação pedagógica e pedagogia da escuta.........................................57

4.2 O aspecto comunicativo e os diferentes interlocutores da prática com documentação pedagógica.

4.3 Organizar o presente, projetar o futuro e conservar a memória: sobre os tempos da prática com documentação pedagógica.

4.4 O lugar da documentação pedagógica nas escolas de educação infantil: condições de trabalho e reconhecimento do desenvolvido...........................................68

4.5 Da confecção de produtos à construção de processos...................................69

4.6 Os limites da documentação pedagógica: qualidade x quantidade..................71

4.7 Estética, escrita e imagens na documentação pedagógica.............................72

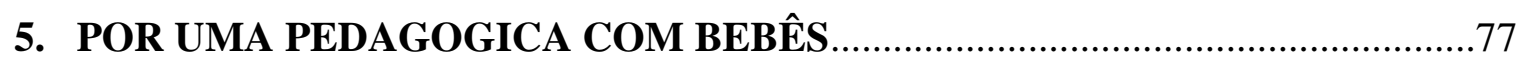

5.1 Os caminhos da educação em creches..........................................................77

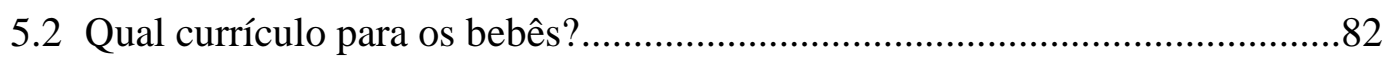

5.3 Profissionalidade docente em creches......................................................87 
5.4 Entre olhares, gestos e silêncios: o que é escutar as crianças bem pequenas

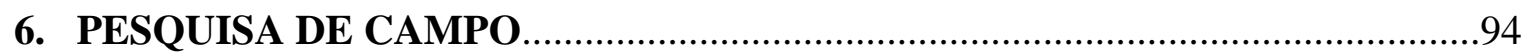

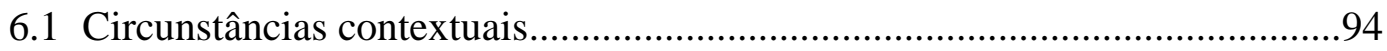

6.2 Sobre as educadoras envolvidas na pesquisa.............................................97

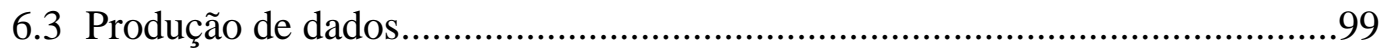

6.3.1 Primeira etapa de inserção no campo................................................101

6.3.2 Segunda etapa de inserção no campo.............................................102

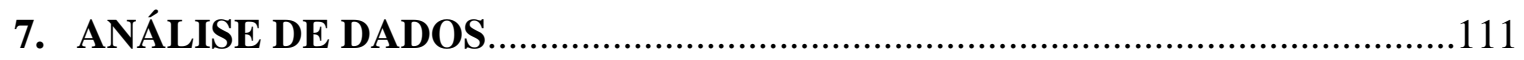

7.1 O olhar para as crianças...........................................................................111

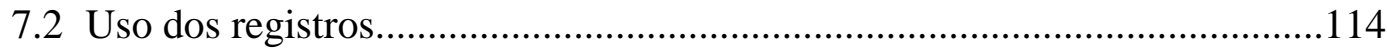

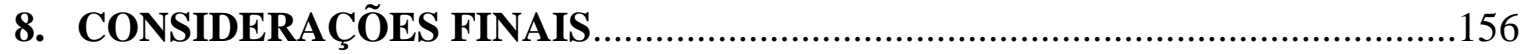

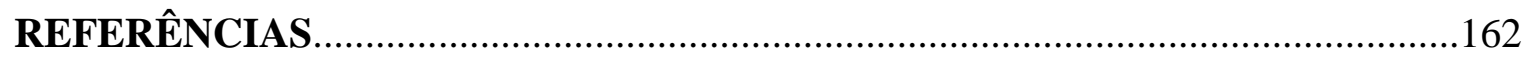

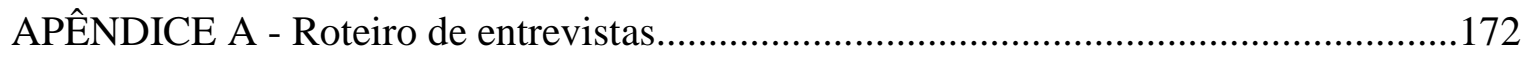

APÊNDICE B - Transcrição das entrevistas com as alterações das educadoras...............173

APÊNDICE C - Transcrição da reunião de orientação do dia 29 de outubro....................186

APÊNDICE D - Modelo de termo de consentimento livre e esclarecido enviado à coordenadora e à diretora da creche.

APÊNDICE E - Modelo de termo de consentimento livre e esclarecido enviado às

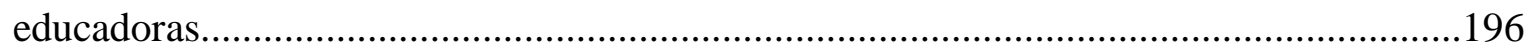

APÊNDICE F - Modelo de autorização de uso de imagem das crianças..........................197

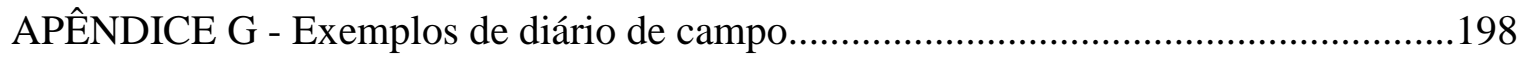

ANEXO A - Exemplo da ficha de planejamento da creche............................................202

ANEXO B - Transcrição dos planejamentos do Grupo Azul do ano de 2012 ..................203

ANEXO C - Transcrição do Projeto "Ritmos Coloridos" - Grupo Azul 2012 .................213 


\section{INTRODUÇÃO}

Uma pesquisa pretende responder algumas perguntas e o ingresso no mestrado marca a retomada de uma busca de sentido e aprofundamento teórico que nasce durante a graduação, a partir do curso de Pedagogia e da participação em pesquisas no grupo Contextos Integrados de Educação Infantil ${ }^{1}$. Essa busca de aprofundamento teórico teve sempre suas bases na educação da infância e concentra sua atenção nos registros elaborados pelos professores ${ }^{2}$ como recurso para sua prática reflexiva no âmbito do trabalho cotidiano com as crianças.

A participação de um seminário sobre a Pedagogia das Relações em parceria com a Faculdade de Psicologia da Università degli studi di Parma e da ParmaInfanzia ${ }^{3}$, no âmbito de uma viagem de estudos promovida pelo grupo de pesquisas Contextos Integrados de Educação Infantil, foi decisiva para que se compreendesse os registros e documentação que as instituições desenvolviam a partir dos percursos com as crianças. Associado ao interesse que a experiência em Parma suscitou, a prática de registros já acompanhava a pesquisadora enquanto professora de educação infantil sempre de crianças bem pequenas, entre zero e três anos. Com o tempo o interesse cresceu a partir da associação entre o exercício da profissão docente e as teorias buscadas sobre registros e documentação, originando a intenção de uma pesquisa em que se pudesse afinar o olhar sobre o tema da documentação pedagógica com bebês. Essa busca pelo sentido dos registros e das produções docentes no cotidiano do trabalho com as crianças gerou a inquietação e a análise de o que de fato esses documentos revelam. O lugar da pesquisadora também como formadora de professores, que aconteceu ao longo do percurso no mestrado, reforçaram ainda mais o interesse pelo tema pesquisado.

A produção de documentos escolares é bastante antiga. Mogarro (2006), ao defendêlos como patrimônio da cultura escolar ressalta o crescente interesse pela preservação da memória das escolas por meio de suas documentações. Apesar de a produção de documentos já vir de longa data, o interesse pelos chamados documentos pedagógicos é recente e como aponta Rinaldi (2012) o conceito de documentação como possibilidade de reflexão do fazer docente ingressa na esfera escolar e atribui um novo sentido a este termo. Barbosa (2012)

\footnotetext{
${ }^{1}$ Grupo de Pesquisa coordenado pelas Prof ${ }^{\mathrm{a}}$. Dra . Mônica Appezzato Pinazza e Prof $^{\mathrm{a}}$. Dr ${ }^{\mathrm{a}}$. Tizuko Morchida Kishimoto na Faculdade de Educação da Universidade de São Paulo.

${ }^{2}$ Neste texto, será empregada a forma masculina "professor" (e seu plural, "professores") com sentido genérico e amplo, englobando todos os profissionais, sem distinção de sexo. $\mathrm{O}$ gênero feminino reserva-se quando as referências disserem respeito às profissionais envolvidas na pesquisa, em sua totalidade, mulheres.

${ }^{3}$ Organização público/privada responsável por um programa para a Infância na cidade de Parma, ocupando-se da promoção e difusão dos trabalhos educativos desenvolvidos mediante a promoção de eventos e programas de estudos.
} 
recorre à expressão documentação pedagógica para definir o novo conceito que o termo documentação ganha no campo educacional, referindo-se às documentações que têm em sua base a prática reflexiva dos professores.

A associação entre a produção de documentos e o fazer do professor, permeado pelo constante (re)pensar de sua atuação com as crianças aparece em pensadores muito importantes no campo da educação como John Dewey e Célestin Freinet, contudo, a expressão documentação pedagógica é recente e vem ganhando força nos últimos anos, especialmente nas escolas de educação infantil.

O interesse pela documentação pedagógica em contexto de creche foi crescente ao longo da trajetória da pesquisadora, resultando neste trabalho intitulado " $A$ documentação pedagógica e o trabalho com bebês: estudo de caso em uma creche universitária”, que buscou compreender a relação entre a produção dos registros escolares e quanto eles se configuravam como documentações pedagógicas que proporcionassem a prática reflexiva e o olhar para os bebês.

O presente trabalho analisou os registros de professoras de educação infantil que atuam junto a um agrupamento de berçário para compreender em que medida essas produções evidenciam a criança pequena e sustentam a ação reflexiva do professor. Ao apostar na potência dos registros como base para o trabalho com a documentação pedagógica, acredita-se que essa prática influi positivamente no planejamento das ações docentes a partir do olhar qualificado aos bebês, o que significa considerá-los integralmente em suas múltiplas linguagens. $\mathrm{O}$ fato dos bebês ainda não falarem convencionalmente desafia os adultos a escutá-los e compreendê-los em suas possibilidades expressivas que envolvem a leitura de gestos, emoções, movimentos, e que só são possíveis quando, nas suas relações com o mundo, estão presentes adultos sensíveis, atentos e disponíveis.

Oliveira-Formosinho (2007), ao recuperar a expressão inglesa "As crianças devem ser vistas, mas não ouvidas" e sua ressonância no campo educacional para a primeira infância enfatiza a necessidade de subversão desse equívoco que recai sobre as crianças e também sobre os pedagogos na medida em que são ignorados os seus saberes da práxis. Em defesa de uma posição contrária à invisibilidade infantil e docente, a autora defende uma Pedagogia da Infância que envolva essencialmente as vozes dos pedagogos, uma vez que:

São vozes antigas que transportam uma sabedoria que precisamos escutar com urgência para desenvolver uma outra pedagogia: uma pedagogia transformativa, que credita a criança com direitos, compreende a sua competência, escuta a sua voz para transformar a ação pedagógica em uma atividade compartilhada (OLIVEIRA-FORMOSINHO, 2007, p. 7). 
Nesse sentido, esta pesquisa teve como perspectiva o campo das práticas escolares com bebês e busca compreender como eles estão evidenciados na ação reflexiva do professor que é instrumentalizada por meio dos registros e da documentação pedagógica. Dessa forma, buscou-se responder a três questões fundamentais: 1) Como os registros periódicos evidenciam o olhar para os bebês?; 2) Como os registros podem se transformar em documentações pedagógicas com vistas ao planejamento e àavaliação das práticas?; 3) Como as documentações pedagógicas estão a serviço da prática reflexiva do professor?

\subsection{Percurso metodológico}

Pesquisa é investigação, um estudo deliberado, uma busca pela compreensão.

STAKE, 2011

A busca pela compreensão de como a documentação pedagógica e os registros efetivam-se como recurso para a ação reflexiva de professores de creche e reconfigura as práticas com os bebês foi o norte dessa investigação. O presente estudo é de natureza qualitativa, ou seja, uma investigação que não se limita a termos de causa e efeito e, segundo Oliveira-Formosinho (2002), caracteriza-se como um conjunto de práticas interpretativas. Segundo Stake (2011), um estudo qualitativo é:

- Interpretativo, porque se fixa nos significados das relações humanas e as descobertas são fruto das interações entre pesquisador e sujeitos envolvidos;

- Experiencial, porque se relaciona diretamente ao campo e está em sintonia com a visão de que a realidade é uma obra humana;

- Situacional, ou seja, refere-se a situações únicas, a contextos determinados;

- Personalístico, porque é empático e trabalha as percepções individuais, busca a singularidade mais que a semelhança.

A pesquisa qualitativa destaca-se pelo esclarecimento das complexas relações entre tudo que existe nos contextos pesquisados (STAKE, 1999), tem como base a subjetividade da análise que valoriza a realidade de cada contexto. Gómez, Flores e Jiménez (1996) acrescentam que o percurso qualitativo se interessa pela compreensão de um cenário social 
concreto e esta pesquisa tem como cenário uma creche universitária da cidade de São Paulo e visa compreender como os registros e a documentação pedagógica proporcionam a prática reflexiva do professor e auxilia como instrumento de visibilidade dos bebês.

Para a realização deste estudo optou-se por uma primeira imersão, nos moldes de uma investigação qualitativa com inspiração etnográfica, no contexto da creche para aproximação da pesquisadora e mapeamento do campo, movimento realizado no ano de 2011.

Após esta primeira vivência no contexto pesquisado, ao longo do ano de 2012 realizou-se uma segunda etapa de imersão na creche que constou da produção de dados de pesquisa propriamente dita e baseou-se na observação participante. A observação participante é marcada pelo envolvimento do pesquisador no contexto pesquisado e pode ser de três tipos (LANKSHEAR; KNOBEL, 2008, p. 192):

- Imersão completa, mas anônima em um grupo social;

- Participação plena e explícita, isto é, os participantes sabem que o pesquisador os está estudando;

- Participação periférica que envolve mistura de participação plena, participação parcial e não-participação, dependendo dos eventos ou das atividades que estão sendo observadas

A pesquisa que ora observou e analisou a prática das educadoras envolvidas, ora participou de intervenções pontuais dessa prática, pode ser enquadrada como uma participação observante periférica na qual a pesquisadora se juntou à atividade como participante, não apenas para se aproximar dos sujeitos envolvidos, mas para tentar aprender algo com a experiência vivida em campo, conforme aponta Stake (2011) sobre essa metodologia de pesquisa.

Ao delimitar as práticas pedagógicas de três educadoras do agrupamento de crianças entre zero e um ano de idade, a pesquisa também se configura como um estudo de caso. Essa abordagem possibilita aprofundamento de uma problemática num contexto de atuação específico e traz reflexões e contribuições para todos envolvidos, pois carrega as vivências dos sujeitos que dela participam, possibilitando troca de saberes e enriquecimento profissional.

$\mathrm{Na}$ direção de compreender fenômenos sociais complexos a questão de pesquisa com estudos de caso centra-se no "como" e "por quê", não exige controle sobre eventos comportamentais e focaliza acontecimentos contemporâneos (YIN, 2005). 
O poder do estudo de caso está na observação direta dos acontecimentos e sua capacidade de lidar com ampla variedade de evidências - documentos, artefatos, entrevistas e observações (YIN, 2005). O estudo de caso é uma investigação empírica que:

- investiga um fenômeno contemporâneo dentro de seu contexto da vida real, especialmente quando

- os limites entre o fenômeno e o contexto não estão claramente definidos.

(YIN, 2005, p. 32)

A investigação de estudo de caso é uma estratégia de pesquisa abrangente, pode ser um estudo de caso único ou de casos múltiplos e é utilizado quando se quer lidar com condições contextuais (YIN, 2005), por isso não se preocupa em propor generalizações. Propõe a reflexão e o foco particularizado, tentando compreender um contexto da vida real que não pode ser generalizado, pois segundo Walsh (2003):

Um contexto é um espaço e um tempo cultural e historicamente situado, um aqui e agora específico. É o elo de união entre as categorias analíticas dos acontecimentos macrossociais e microssociais. O contexto é o mundo apreendido através da interação e o quadro de referência mais imediato para atores mutuamente envolvidos" (p. 25).

No âmbito desta investigação, o caso é definido pelo contexto do agrupamento de crianças entre zero e um ano e a prática das educadoras no que envolve a produção de registros e documentações para sua atuação com os bebês. Para o desenvolvimento da pesquisa, valeu-se da produção de dados entendida como fragmentos e peças de informação encontradas no ambiente que proporcionam a base das evidências a partir das quais são feitas as interpretações (LANKSHEAR; KNOBEL, 2008). Os dados envolvem três naturezas distintas, conforme propõem Lankshear e Knobel (2008): dados verbais, dados observados e dados escritos.

Neste estudo os dados verbais configuram-se como entrevistas semiestruturadas realizadas com as educadoras envolvidas, ou seja, partiram de um roteiro proposto previamente, mas possibilitaram a abertura para comentários não estabelecidos antecipadamente. Os dados observados envolvem as situações do dia-a-dia da creche acompanhadas pela pesquisadora, traduzidos em observações em sala de aula, o processo da exposição de artes e reunião de formação. Por fim, os dados escritos envolvem o conjunto de documentos produzidos pela creche a que a pesquisadora teve acesso.

Os dados passaram pelo processo de triangulação, conforme proposto por Stake (2011), movimento que buscou agrupar os materiais da pesquisa na busca da interpretação dos resultados. 


\subsection{0 contexto pesquisado}

\subsubsection{A chegada de Caetano: um convite a entrar na creche}

Com o propósito de compreender como os registros podem ou não se tornarem documentações pedagógicas e servirem como instrumentos de prática reflexiva e base estruturante para maior visibilidade dos bebês, a pesquisa procurou eleger um contexto de creche em que a documentação pedagógica fosse alvo de tematização por parte da equipe.

No intuito de convidar o leitor a entrar no contexto da pesquisa, apresentaremos a creche a partir dos registros de nota de campo referentes à chegada de uma nova criança, processo acompanhado pela pesquisadora ao longo da imersão de inspiração etnográfica realizada em 2011.

Era início do ano e como toda instituição infantil, a creche passava pelo período de ingresso das crianças, movimento amplamente nomeado como "período de adaptação" nas instituições infantis (inclusive na creche pesquisada), embora se reconheçam os limites de seu uso $^{4}$ :

Era uma sexta-feira, a primeira semana de Caetano na escola. Ele vai à creche apenas no período da tarde. Chega com sua mãe que parece já estar familiarizada com os procedimentos da escola. Ela acomoda a mochila de seu filho e segue com ele para a sala em que se encontra o grupo. As professoras tranquilamente convidam Caetano para as propostas e incentivam sua mãe a lhe fazer companhia. O menino parece bastante interessado e as educadoras intensificam sua relação com ele. Algumas vezes, Caetano procura por sua mãe e prefere ficar perto dela, outras vezes se mostra mais à vontade e arrisca-se a distanciar-se.

Durante as observações é perceptível o profundo respeito das professoras com o tempo do Caetano. Elas respeitam suas escolhas e parecem bem seguras e certas de que com o passar dos dias ele conseguirá ficar bem na creche sem sua mãe. Em nenhum momento elas intervêm de forma impositiva e o deixam à vontade para recorrer à sua mãe sempre que deseja. $\mathrm{Na}$ terceira semana a mãe de Caetano não está na sala e uma das professoras responde que ele já consegue estar sem ela, que às vezes chora na despedida, mas logo se envolve nas brincadeiras e passa a tarde toda muito bem.

Ao acompanhar o processo de adaptação de Caetano era visível a profunda tranquilidade das educadoras, essa atmosfera de dar tempo ao tempo a essa

\footnotetext{
${ }^{4}$ O termo "adaptação" tem sido questionado no campo da educação infantil por restringir o momento tão importante de ingresso da criança à creche como um momento em que a criança se adapta no sentido de se enquadrar às regras e padrões da instituição. Contrariamente a essa visão limitada, propõe-se um processo de inserção gradual que considere os tempos das crianças e seja feito em parceria das famílias. Trabalhos como o de Pantalena (2010) sugerem o termo "inserimento" como mais adequado ao ingresso da criança à creche por compreender o início de uma rede complexa de relações e comunicações que se dará entre adultos e crianças, escola e família com a chegada das crianças à creche. Concebe-se assim uma vivência não apenas pelas crianças, mas também pelas famílias e pela instituição já que todos estão em um processo de estabelecimento de vínculos.
} 
criança pareceu fundamental e vai ao encontro de concepções de boa qualidade de educação infantil que compreendem esse processo como extremamente importante para o respeito à criança e sua família.

$\mathrm{O}$ processo de chegadas das crianças à creche ganha anualmente maior espaço durante a primeira quinzena de junho quando, na semana das reuniões de pais, organiza-se uma exposição de todos os grupos onde se retratam os projetos desenvolvidos para acolher as crianças no momento de chegada. Nessa exposição foi possível novamente perceber o respeito às crianças e suas famílias durante o período de ingresso à creche, também observado quando a coordenadora solicita à pesquisadora que adie sua inserção em campo, visto que o grupo estava em pleno processo de recepção das novas crianças. Com isso, nota-se o respeito às crianças que naquele momento passavam por um processo delicado no qual era necessária forte vinculação com seus educadores e no ambiente educativo. Foi enriquecedor acompanhar o ingresso de Caetano e dessa forma poder compreender como a instituição pensa o processo de entrada das crianças à creche.

Diário de campo 2011

Como Caetano, convidamos o leitor a também se inserir no contexto dessa instituição envolvida na pesquisa que é uma creche universitária da cidade de São Paulo e sua criação é marcada, como a história da instituição infantil no Brasil, por uma forte luta das mulheres, neste caso compostas por funcionárias, alunas e docentes da universidade da qual faz parte. Com a entrada das mulheres no mercado de trabalho, a instituição de educação infantil passa a ser essencial na vida das pessoas e é em 1986 que a creche é construída, tornando-se a segunda creche da universidade. Inicia seu atendimento em uma pequena construção (atualmente chamada de "Casinha") que ainda é conservada e onde são recebidas as crianças do berçário (grupo denominado Grupo Azul).

Com o passar dos anos, a creche ganhou novos espaços e ampliou seu atendimento que atualmente é em torno de 110 crianças. Desde sua criação é mantida integralmente por recursos da universidade, fazendo parte da Assistência Social. Justamente por fazer parte do serviço social, a instituição não é reconhecida como educação, os profissionais são contratados como educadores e não professores, e tais condições acarretam constantes discussões e lutas dos funcionários. Há uma forte defesa da creche e das demais creches dessa universidade em favor de seu reconhecimento educativo e não apenas assistencial.

\subsubsection{Termos éticos da pesquisa}


Na pesquisa qualitativa estão em jogo ações humanas do pesquisador sobre o objeto pesquisado numa constante rede de relações que, como bem colocam Lankshear e Knobel (2008), deve pautar-se na ética da pesquisa a fim de garantir que os interesses e o bem-estar das pessoas não venham a ser prejudicados.

Lankshear e Knobel (2008) discutem ainda a questão da ética em pesquisas qualitativas sob alguns princípios: ter um projeto de pesquisa válido, obter consentimentos dos participantes, evitar a omissão, minimizar a intromissão, garantir a confiabilidade, minimizar o risco de danos, demonstrar respeito, evitar coerção ou manipulação e reciprocidade.

Com o intuito de atender aos critérios éticos esta pesquisa garantiu o anonimato da instituição envolvida bem como o dos profissionais que participaram diretamente do estudo, quais sejam as educadoras, a coordenadora pedagógica e as próprias crianças.

No início da imersão em campo foram apresentados à Comissão de Ética e Pesquisa da Faculdade de Educação da Universidade de São Paulo os termos a serem enviados à creche que devidamente aprovados pela Comissão foram preenchidos e se encontram de posse da pesquisadora. Os termos foram enviados à equipe gestora, às três educadoras do estudo, bem como às famílias dos bebês a fim de autorizarem o uso de imagens. Os modelos dos termos podem ser verificados nos apêndices.

Sobre a ética com relação à realização das entrevistas concedidas pelas educadoras teve-se o cuidado de após terem sido gravadas em áudio, serem transcritas e devolvidas a cada entrevistada para que fosse feita a revisão e posterior alteração no texto final. Nos apêndices constam as transcrições com as alterações solicitadas pelas entrevistadas bem como o roteiro seguido para a realização das entrevistas.

Estabeleceu-se ainda o compromisso de devolutiva da pesquisa à creche participante visando apresentar aos sujeitos envolvidos os dados produzidos ao longo do estudo e analisados pela pesquisadora.

\subsection{Conceitos adotados na pesquisa}

[...] as palavras produzem sentido, criam realidade e, às vezes, funcionam como potentes mecanismos de subjetivação. 
É importante esclarecer os termos utilizados pela pesquisadora e o que deve ser compreendido ao longo do texto sobre registros, documentação e documentação pedagógica.

A produção de registros do cotidiano escolar do educador e o seu uso para a prática reflexiva é tema de diversos trabalhos que analisam as mais diversas produções feitas pelos professores. Marques (2010), em sua tese de doutorado, faz um extenso levantamento de autores que se dedicaram sobre o tema, entre eles, os mais relevantes, estão Zabalza (1994) e Warschauer (1993) que falam dos diários de aula como instrumentos de pesquisa e desenvolvimento profissional; Sá-Chaves (2005) que aponta os trabalhos com portfólios como estratégia de aprofundar o conhecimento da relação ensino-aprendizagem e Madalena Freire (1983; 1996) que defende a prática de registros como recurso de reflexão sobre o trabalho docente.

A perspectiva desta pesquisa concorda com os autores citados, no sentido de compreender os registros como enriquecedores da atuação docente e ferramenta para a prática reflexiva do professor, contudo ao longo deste texto quando for referido o termo registro concebe-se a ideia de todo e qualquer documento produzido pelo professor com vistas a deixar marcas sobre sua atuação e não necessariamente em fazer uso desses recursos para reconstrução de sua prática.

O termo documentação aparece na literatura consultada com sentidos diversos. Helm e Beneke (2005) defendem a documentação como uma coleção de registros dos educadores constituindo-se uma "documentação crua" que só se torna uma verdadeira documentação quando reorganizada e compartilhada com outras pessoas, sejam elas os pais, educadores ou membros da comunidade. Documentação, segundo elas, está intimamente ligada à memória, à comunicação e à planificação do trabalho docente, contudo as autoras esclarecem a diferenciação entre documentação e documentação pedagógica. Esta última é vinculada aos trabalhos desenvolvidos nas escolas de Reggio Emilia e incluiriam uma reunião de documentações que é estudada com o propósito de compreender os processos das experiências das crianças.

Ampliando esse diálogo, Hoyuelos (2006) aborda a concepção de documentação no que tange ao agrupamento de registros, sua posterior análise e interpretação dos dados vinculados à prática reflexiva do professor, e a reconstrução do fazer docente dentro de uma perspectiva de escuta das crianças. Apesar dessa concepção ampliada o autor faz uso apenas do termo documentação. Da mesma forma referem-se com este sentido o termodocumentação os trabalhos de Gandini e Goldhaber (2002), Kinney e Wharton (2009) e 
Rinaldi (2012), Benzoni (2001), Davoli (2011), Malavasi e Zoccatelli (2012), Paige-Smith e Craft (2010), Oliveira-Formosinho (2007). A mesma concepção é defendida por Dahlberg, Moss e Pence (2003), ainda que neste caso os autores recorram ao termo documentação pedagógica.

Para guiar a leitura é importante frisar que a pesquisadora considera, neste estudo, a distinção entre os três termos, ainda que possa haver algumas semelhanças entre eles: sobre o termo registros compreende-se toda e qualquer forma de dado coletado pelos professores ao longo do trabalho cotidiano com as crianças a incluir planejamentos, diários, fotografias, vídeos, desenhos, entre outros. Acerca da palavra documentação compreende-se a organização dos registros com vistas a um produto que comunique, por exemplo, uma exposição que reúna imagens, desenhos, escritas e apresenta um percurso em forma de um produto estético-visual. Por fim, a expressão documentação pedagógica é considerada em uma perspectiva ampliada, que se concretiza a partir do uso dos registros e de documentações com vistas à interpretação dos processos vividos, em que se possa pautar um planejamento flexível e uma pedagogia da escuta.

\subsection{Estrutura da dissertação}

O presente trabalho está organizado em nove capítulos. O primeiro deles, em vias de encerramento, introduz o tema buscando contextualizar a proposta, apresentar o percurso metodológico e o contexto pesquisado.

O segundo capítulo - Sobre o termo documento: entre monumento, fonte documental e memória - discute a origem do termo documento dentro do campo da História no sentido de resgatar o significado que a palavra documentação traz em sua essência para o campo da Educação.

O terceiro capítulo - Bases da documentação pedagógica: a prática reflexiva a partir dos registros - aborda a discussão da prática reflexiva do professor e propõe a construção de uma escola reflexiva, sendo esta uma discussão necessária para o trabalho com documentação pedagógica.

O quarto capítulo - Abordagem da documentação pedagógica - é dedicado à documentação pedagógica e ao sentido deste trabalho, sustentado especialmente pela 
abordagem italiana e pelos trabalhos desenvolvidos na Associação Criança, sob orientação da Prof $^{\mathrm{a}}$. Dr ${ }^{\mathrm{a}}$. Julia Oliveira-Formosinho, em Portugal.

O quinto capítulo - Por uma pedagogia com bebês - faz um resgate histórico das instituições dedicadas à primeira infância no Brasil e, ao discutir questões como a profissionalidade docente de professores de creche e o currículo para crianças bem pequenas, defende uma pedagogia específica para a faixa de zero a três anos.

O sexto capítulo - Pesquisa de campo - apresenta detalhadamente o contexto pesquisado, no caso uma creche universitária da cidade de São Paulo; aponta quem são os sujeitos da pesquisa, ou seja, as três educadoras envolvidas no estudo; e apresenta os dados produzidos.

O sétimo capítulo - Análise de dados - apresenta a análise dos dados produzidos organizados por duas categorias: o olhar para as crianças e o uso dos registros.

Por fim, o oitavo capítulo apresenta as Considerações finais, o qual não pretende ser conclusivo, mas indica contribuições da pesquisa e possibilidades de futuros estudos no campo. 


\section{SOBRE O TERMO DOCUMENTO: ENTRE MONUMENTO, FONTE DOCUMENTAL E MEMÓRIA}

Para uma pesquisa sobre documentação pedagógica pareceu-nos fundamental resgatar o sentido e significado que o termo documentação carrega em si. Ligado intimamente com o campo da História, é lá que vamos buscar a discussão da palavra documento para ampliar o sentido histórico-documental das documentações pedagógicas em contextos educativos para a primeira infância.

Jacques Le Goff (2000), ao refletir sobre a memória coletiva dentro da perspectiva

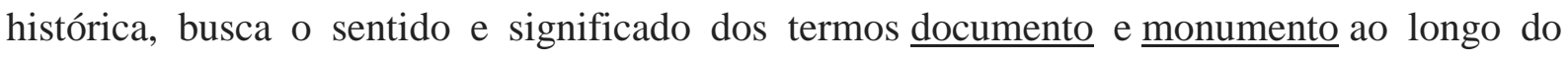
tempo. Ele afirma que a memória coletiva é materializada por meio de duas formas: os documentos e os monumentos, o que os define é o que sobrevive ao tempo, fruto de escolhas feitas pelas forças que operam no desenvolvimento do mundo em determinado período.

A palavra latina monumentum remete à 'memória', 'recordação', 'iluminação', 'instrução'. Monumento é um sinal do passado, mas desde a Antiguidade romana tendeu a definir-se como obra de arquitetura ou escultura de caráter comemorativo (arco do triunfo, coluna, troféu, pórtico) ou monumento funerário destinado a perpetuar a memória ligada à morte. Já o termo documentum, derivado de 'ensinar' evolui para 'prova' e só terá o sentido de testemunho histórico no século XIX, quando se apresenta como prova histórica e se afirma essencialmente como testemunho escrito. A leitura de um documento só tem validade quando feita sem ideias pré-concebidas do historiador, devendo este extrair dos materiais somente aquilo que contém.

A palavra 'documento' triunfa sobre o termo 'monumento' em um processo lento. Seu sentido se mantém, porém seu conteúdo amplia-se de apenas textos escritos para outros recursos que também servem como prova histórica do passado, como o saber das histórias orais (fábulas, mitos, sonhos, fantasias); ilustrações; imagens; e sons, e defende-se o resgate de tudo aquilo que pertence ao homem e foi produzido por ele, depende dele, o exprime, demonstra presença, atividades, gostos e maneiras de ser do homem.

Le Goff (2000) fala de uma revolução documentária quantitativa e qualitativa, explicada pela ampliação do conceito documento que passa a abranger diversas formas de perpetuação da memória atrelada ao interesse pelas memórias coletivas de massas, não mais importa apenas os grandes homens que estiveram no poder, mas todos os homens, inaugurando a documentação de massa que só foi possível com o advento da tecnologia 
representada especialmente pelo computador. Essa revolução documentária promove uma nova unidade de informação. Se antes os fatos conduziam a uma história linear e progressiva, agora os dados são privilegiados e levam a uma história descontínua na medida em que podem ser analisados e organizados de diversas formas.

A perseguição aos falsos documentos comumente produzidos até a Idade Média se intensifica, apesar de ainda prevalecer a crença da neutralidade. É somente no século XX que se passa a defender que a presença ou ausência de um documento depende de causas humanas e nesse sentido diferem documento de monumento, sendo o primeiro considerado apenas uma forma de intercomunicação e o segundo uma forma de edificação (moral e de construção literalmente). Reflexões mais críticas posteriores acreditam que o que transforma documento em monumento é o poder e não a forma materializada em texto escrito, ilustração ou em uma edificação arquitetônica e, ainda que este seja um avanço, não se reconhece o documento como monumento. A ilusão positivista vê os documentos apenas como provas de boa fé (desde que fossem autênticos).

O autor insiste na indissociável relação documento/monumento e esta concepção é independente da revolução documentária. Se antes os documentos serviam para memorizar os monumentos construídos e deixados pelos homens, atualmente os documentos são transformados em monumentos na medida em que se reconhecem nessas marcas históricas frutos de tempos passados onde estão implícitos ou explícitos valores e poderes. Documento é monumento por sua existência derivar de escolhas das sociedades históricas que impõem ao tempo futuro uma imagem de si, por isso não existe a neutralidade nos documentos. Nas palavras de Le Goff (2000, p. 114):

O documento não é inócuo. Antes de tudo, é o resultado de uma montagem, consciente ou inconsciente, da história, da época, da sociedade que o produziu, mas também das épocas sucessivas durante as quais continuou a ser manipulado, também pelo silêncio. O documento é uma coisa que fica, que dura, e o testemunho, o ensinamento (para evocar a etimologia) que traz devem ser em primeiro lugar analisados desmitificando o seu significado aparente. O documento é monumento. É o resultado do esforço realizado pelas sociedades históricas para impor ao futuro - voluntária ou involuntariamente - determinada imagem de si próprias. No limite, não existe um documento-verdade. Todo documento é mentira. Cabe ao historiador não passar por ingênuo. Os medievalistas, que tanto trabalharam para construir uma crítica - sempre útil, de facto - do falso, devem superar esta problemática porque qualquer documento é, ao mesmo tempo, verdadeiro - incluindo, e talvez sobretudo, os falsos - e falso, porque um monumento é em primeiro lugar uma roupagem, uma aparência enganadora, uma montagem. É preciso começar por desmontar, demolir esta montagem, desestruturar esta construção e analisar as condições de produção dos documentos-monumentos. 
Documento deve ser tratado como monumento para garantir a análise de sua amplitude e todas as relações que estabelece. Não apenas o texto escrito, mas outras fontes são consideradas documento/monumento e analisar em profundidade tais fontes requer abordagens múltiplas. Cardoso e Mauad (1997) tratam dessa ampliação da noção de documento que precisa da aproximação da história com novas disciplinas. Os autores, ao tomarem como estudo a fotografia e o cinema, discorrem sobre uma nova perspectiva documental na qual o historiador passe a valer-se de fontes além dos textos escritos, qualquer tipo de marca, tudo o que é produzido pelo homem torna-se documento. Esse novo conceito de documento transforma a ótica tradicional da história:

Não mais uma história do individual, das singularidades de uma época, sintetizada na ideia de uma narrativa dos grandes fatos e dos grandes vultos. O que está em questão, a partir de então, é o desvendamento das especificidades de épocas históricas, compreendidas a partir de seu caráter transindividual (p. 402).

A discussão dos documentos, considerando-os monumentos e consequentemente marcas criadas pelo homem que atravessam a história, traz como base a discussão e o sentido da memória. Le Goff (2000) atribui aos documentos/monumentos oposto de instrumentos, de matérias da memória e da história. Documentos são marcas deixadas carregadas de valores que a humanidade conserva para cultivar a memória, mas o significado desta não foi o mesmo ao longo da história.

No texto intitulado "Memória", novamente Le Goff (2000) faz uma análise da memória como propriedade de conservar certas informações. Concepções mais amplas da memória estruturaram-se ao longo do tempo para além do entendimento apenas técnico de atualização mecânica de vestígios mnemônicos, considerando-a não apenas ordenação, mas também possibilidade de releitura dos aspectos armazenados. A passagem das sociedades orais às sociedades letradas e que usam o recurso da escrita amplia consideravelmente as possibilidade de memória, desembocando na influência tecnológica que reconfigura os sentidos das memórias. Citando Leroi-Gourhan, enumera três tipos de memória: memória específica (para definir a fixação dos comportamentos de espécies animais), memória étnica (que assegura a reprodução dos comportamentos nas sociedades humanas) e memória artificial (eletrônica que assegura sem recurso ao instinto ou à reflexão, a reprodução de atos mecânicos encadeados). Ainda inspirado por este autor, Le Goff (2000) faz um estudo da memória através da história organizado em cinco períodos: 
2. O desenvolvimento da memória da oralidade à escrita, da Antiguidade à Préhistória

3. A memória medieval, entre o equilíbrio oral e escrito

4. Os progressos da memória escrita e figurada, a partir da Renascença

5. Os desenvolvimentos contemporâneos da memória

A memória étnica refere-se às sociedades primitivas e selvagens que têm na figura do idoso o valor de retentor das tradições, valoriza o caráter mítico e a aprendizagem e conservação dos ofícios, no entanto não se trata de uma memória repetitiva, ela abre o campo para possibilidades criativas e tem na vitalidade da memória duas características marcantes: a transmissão de conhecimentos considerados secretos e a possibilidade de uma memória que se conserva, porém é mais criadora que repetitiva.

O nascimento da escrita configura-se não só como um novo saber técnico, mas como uma nova aptidão intelectual. Duas formas principais de memória ligadas à escrita surgem: as comemorações (na figura dos monumentos comemorativos, de ostentação e durabilidade da memória) e os documentos (armazenam informações que comunicam através do tempo ao oferecer ao homem um processo de marcação, memorização e registro. Ao assegurar a passagem da esfera auditiva à visual permite reexaminar, reordenar frases e palavras).

O período medieval é marcado pela Cristianização da memória e das mnemotécnicas, dividindo a memória coletiva em uma memória laica e uma memória litúrgica. Desenvolve-se a memória aos mortos, principalmente dos santos e articula-se o papel da memória no ensino entre o oral e o escrito, aparecendo, enfim, os tratados de memória. O judaico-cristianismo e o monopólio da Igreja reconfiguram a memória como sinônimo de recordação, a veneração aos velhos vê neles homens-memória, o recurso escrito torna-se suporte da memória e nascem os arquivos. Ainda neste período a memória escrita é fortemente vinculada à memória oral, na literatura a influência da memória a tem como elemento constitutivo, bem como a memória escolar é valorizada no âmbito da 'decoreba' na qual o saber de cor era considerado saber.

No período pós-medieval o surgimento da imprensa revoluciona a memória, embora lentamente, e a partir dela o leitor é colocado na presença de uma memória coletiva enorme, torna-se incapaz de fixá-la e ao mesmo tempo tem possibilidades de explorar textos novos. A distinção entre a oralidade e a escrita fica marcante e o movimento de exteriorização da memória individual é progressivo. Entre o fim da Idade Média, o início da imprensa e o começo do século XVIII há um aparente desinteresse para as questões da memória no campo humanista, mas no século XVIII acontece um verdadeiro alargamento da memória coletiva 
ocasionado pelo saber acumulado nos dicionários e enciclopédias. O século XIX não vê mais tanto a memória associada ao saber e sim a coloca na ordem dos sentimentos, do espírito comemorativo e das festas; o Romantismo reencontra a sedução da memória e a ligação entre memória e imaginação, entre memória e poesia. As comemorações apropriam-se de instrumentos de memória como moedas, medalhas, troféus, e o desenvolvimento do turismo impulsiona o comércio dos souvenirs, também suportes de memória. Nesta mesma época a memória coletiva é fortemente impulsionada pelos monumentos de lembranças, surgem os arquivos nacionais, a era dos museus e das bibliotecas.

No final do século XIX e início do século XX, dois fenômenos significam consideravelmente as memórias coletivas: os monumentos aos mortos (resgatados da Idade Média, que desaparecem no Iluminismo e agora voltam a ter valor) e o surgimento da fotografia (tantos os acervos produzidos nos contextos familiares como a larga produção de postais). Contudo, no século XX pós 1950 , a grande revolução da memória se dá no âmbito do surgimento da memória eletrônica, separa-se esta da memória humana e embora se reconheça na memória eletrônica sua grande potência para além da memória humana ela depende sempre da ação do homem, portanto, é apenas um auxiliar de memória.

A memória eletrônica tem marcadamente duas consequências: a revolução documentária na história, uma nova forma de organização de informações, e um efeito metafórico da memória em outros campos. Por exemplo, no campo biológico, quando se criam termos como memória hereditária, memória genética, memória nervosa-cerebral; e no campo social com a literatura, filosofia, ciências sociais e psicologia. Nesse campo social é relevante mencionar as relações da memória com o espírito, o surrealismo que estabelece a relação entre sonho e memória e os estudos de Freud que exploram as memórias consciente e inconsciente. A memória coletiva sofre profundas transformações no campo das ciências sociais:

Pesquisa, salvamento, exaltação da memória coletiva não mais nos acontecimentos mas ao longo do tempo, busca dessa memória menos nos textos do que nas palavras, nas imagens, nos gestos, nos ritos e nas festas; é uma conversão do olhar histórico. Conversão partilhada pelo grande público, obcecado pelo medo de uma perda de memória, de uma amnésia coletiva, que se exprime desajeitadamente na moda retrô, explorada sem vergonha pelos marcadores de memória desde que a memória se tornou um dos objetos da sociedade de consumo que se vende bem (LE GOFF, 2000, p. 466).

Citando Pierre Nora, Le Goff (2000) afirma que os estudos da memória e o campo da história confundem-se até os nossos dias e a história está constantemente sob pressão das 
memórias coletivas. A Nova História esforça-se por criar uma história científica a partir da memória coletiva o que gera uma revolução na memória, que passa a ser compreendida não mais linearmente, mas em torno de eixos fundamentais nos quais o individual se enraíza no social e coletivo. Essa nova história emerge principalmente do estudo dos lugares da memória coletiva (lugares topográficos, lugares monumentais, lugares simbólicos, lugares funcionais), muito embora não se possam esquecer os verdadeiros lugares da memória coletiva: "estados, meios sociais e políticos, comunidades de experiências históricas ou de gerações levadas a constituir os seus arquivos em função dos usos diferentes que fazem da memória" (NORA, 1978, Apud LE GOFF, 2000).

Essa nova memória coletiva constitui-se a partir dos instrumentos tradicionais, mas também se manifesta em novos arquivos, sobretudo os arquivos orais onde se frutificam as 'histórias de vida'. As memórias coletivas fazem parte das grandes questões das sociedades:

Exorbitando a história como ciência e como culto público, ao mesmo tempo a montante, enquanto reservatório (móvel) da história, rico em arquivos e em documentos/monumentos, e aval, eco sonoro (e vivo) do trabalho histórico, a memória coletiva faz parte das grandes questões das sociedades desenvolvidas e das sociedades em vias de desenvolvimento, das classes dominantes e das classes dominadas, lutando, todas, pelo poder ou pela vida, pela sobrevivência e pela promoção (LE GOFF, 2000, p. 469).

Pierre Nora (1993) problematiza o sentido da memória nos nossos tempos das sociedades complexas ao defender que se fala tanto de memória porque ela não existe mais, o que existem são os lugares de memória. Os processos de mundialização, democratização, massificação e midiatização dão fim às sociedades-memória. Com isso a inevitável distância entre memória e história. A primeira, entendida como memória verdadeira intocada das sociedades arcaicas, que guardam, consigo, o segredo e, a segunda, definida como história é o cerne das nossas sociedades contemporâneas porque condenadas ao esquecimento fazem do passado vestígio e trilha. Havendo rastro, distância e mediação, não estamos mais dentro da verdadeira memória, mas dentro da história e por não habitarmos mais as nossas memórias, lhe consagramos lugares. (NORA, 1993, p. 9). A história se ocupa de destruir a memória espontânea e a distância entre memória e história é evidente e descrita pelo autor:

Memória, história: longe de serem sinônimos, tomamos consciência que tudo opõe uma à outra. A memória é a vida, sempre carregada por grupos vivos e, nesse sentido, ela está em permanente evolução, aberta à dialética da lembrança e do esquecimento, inconsciente de suas deformações sucessivas, vulnerável a todos os usos e manipulações, susceptível de longas latências e de repentinas revitalizações. A história é a reconstrução sempre problemática e incompleta do que não existe mais. A memória é um fenômeno sempre atual, um elo vivido no eterno presente; a história, uma representação do passado. Porque é afetiva e mágica, a memória não se acomoda a detalhes 
que a confortam; ela se alimenta de lembranças vagas, telescópicas, globais ou flutuantes, particulares ou simbólicas, sensível a todas as transferências, cenas, censura ou projeções. A história, porque operação intelectual e laicizante, demanda análise e discurso crítico. A memória instala a lembrança no sagrado, a história a liberta, e a torna sempre prosaica. A memória emerge de um grupo que ela une, o que quer dizer, como Halbwachs o fez, que há tantas memórias quantos grupos existem; que ela é, por natureza, múltipla e desacelerada, coletiva, plural e individualizada. A história, ao contrário, pertence a todos e a ninguém, o que lhe dá uma vocação para o universal. A memória se enraíza no concreto, no espaço, no gesto, na imagem, no objeto. A história só se liga às continuidades temporais, às evoluções e às relações das coisas. A memória é um absoluto e a história só conhece o relativo (NORA, 1993, p. 9).

O sinal mais tangível desse arrancar da história da memória é o nascimento da 'história da história' e no centro dessa dissociação estabelece-se o tempo dos lugares. É o fim da intimidade da memória para uma história reconstruída. Os lugares de memória são restos, existem para não esquecermos e daí o seu paradoxo: criados como ilusões da eternidade eles nascem e vivem do sentimento de que não há memória espontânea, são construídos para preservar a memória, mas esta já não existe mais. Precisamos dos lugares de memória porque sem eles já não lembramos mais e o que os constitui são momentos de história arrancados do movimento da história, porém parcialmente devolvidos.

O que chamamos de memória é, na verdade, história, mas é impossível não precisar da palavra memória, o que nos adverte Nora (1993) é que o risco não é usar os dois termos, mas ter a clareza da diferença e distância deles. Três traços são característicos desse processo de transformação da memória em história. O primeiro deles, a memória-arquivo: quanto menos a memória é vivida, mais ela precisa de suportes e o que se inicia com o surgimento da escrita culmina na obsessão pelos arquivos. A sociedade moderna é extremamente produtora de arquivos, que vive sob uma acumulação documentária que se tornam provas, é uma vontade geral pelos registros e produzir arquivos é o imperativo da época.

Essa memória vem do exterior e nós a interiorizamos, não é mais prática social, multiplicam-se as particularidades que reclamam sua própria história. Menos a memória é vivida coletivamente, mais ela necessita de homens particulares que precisam fazer de si homens-memória. Eis o segundo traço, a memória-dever.

Por fim há ainda a memória-distância, uma nova relação com o tempo. Antigamente o passado não era verdadeiramente passado, bastava lembrar-se. Para que haja um sentimento do passado, marca dos lugares de memória, é necessário um espaçamento entre passado e presente, entre um antes e um depois. Na mesma direção, de um presente que prevê um futuro balizado e manipulável, emerge um futuro invisível. O paradoxo da distância reside na 
necessidade que temos de reaproximação, buscamos nos aproximar do passado para nos apropriarmos daquilo que sabemos não mais nos pertencer.

Os lugares de memória possuem em si os três sentidos da palavra lugar: material, simbólico e funcional, os três fatores coexistem, o que muda é a intensidade de cada um deles. O que constitui um lugar de memória é um misto de memória e história, se por um lado há que existir a vontade de memória, por outro, a dinâmica dos lugares e sua capacidade de metamorfose é o que vai continuamente revendo seus significados. É a memória quem dita e a história quem escreve, a memória pendura-se em lugares como a história em acontecimentos. Um lugar de memória (seja o arquivo, museu, biblioteca, dicionário, construção ou mesmo as festas) é um lugar duplo também porque apesar de ser um espaço do excesso, fechado em si mesmo está, simultaneamente, aberto para a extensão de suas significações.

Mas voltando ao termo memória, é claro que ela é elemento essencial da identidade individual ou coletiva e esta última é uma conquista, mas também instrumento e objeto de poder, por isso torna-se fundamental uma democratização da memória. Memória, âmbito no qual cresce a história que por sua vez a alimenta procura salvar o passado, servir ao presente e ao futuro, por isso é preciso que sirva como libertação e não servidão dos homens (LE GOFF, 2000).

Ao percorrermos os campos dos documentos e da memória sustentamos a discussão de como a repercussão desses movimentos da sociedade contemporânea recai sobre o campo educacional. A escola toma para si também a produção de documentos, arquivos e memória. Mogarro (2006) aposta na importância do lugar do arquivo na instituição escolar como construção da memória e identidade educativa, aponta o longo caminho a percorrer para que se intensifiquem as preocupações arquivísticas escolares, fontes valiosas para o estudo da cultura escolar, patrimônio da atualidade. Os documentos de arquivo refletem a vida das instituições que os produziu e são materializados em diversas formas, desde documentos mais burocráticos e organizativos, como aqueles considerados pedagógicos que atestam o fazer dos professores. O conjunto desses documentos são fontes de informações que revelam os poderes implícitos nas suas formas documentais e os processos de escolha e seleção pelos quais sobreviveram ao tempo.

Segundo a autora, ao analisarmos os arquivos de uma instituição são muitas as fontes documentais a serem consideradas e o cruzamento de informações entre elas é fundamental para uma análise em profundidade que deve sempre levar em consideração a arqueologia da escola, dando atenção aos silêncios da história do ensino. No interior de estruturas complexas as pessoas são produtoras de cultura, por isso analisar os documentos da escola é debruçar-se 
sobre uma cultura específica e também desvendar as relações de poder e de comunicação. A cultura escolar não pode apenas ser vista como mero prolongamento das culturas da sociedade. Embora se relacione com elas, deve ter seu lugar próprio. Mogarro aponta o crescente interesse nos últimos anos pelo passado da escola e a busca incessante de documentos escolares, entendendo a cultura escolar como:

Constituída por um conjunto de teorias, saberes, ideias e princípios, normas, regras, rituais, rotinas, hábitos e práticas, a cultura escolar, na sua acepção mais lata, remete-nos também para as formas de fazer e de pensar, para os comportamentos, sedimentados ao longo do tempo e que se apresentam como tradições, regularidades e regras, mais subentendidas que expressas, as quais são partilhadas pelos atores educativos no seio das instituições. Os traços característicos da cultura escolar (continuidade, persistência, institucionalização e relativa autonomia) permitem-lhe gerar produtos que lhe dão a configuração de uma cultura independente. Esta cultura constitui um substrato formado, ao longo do tempo, por camadas mais entrelaçadas que sobrepostas, que importa separar e analisar. O exercício do arquivo tem um espaço importante neste processo historiográfico de investigação sobre a cultura escolar (MOGARRO, 2006, p. 80).

A autora diz, ainda, que a procura social de identidade e de recuperação da memória em torno da escola sustenta-se no crescente interesse pelos documentos escolares produzidos ao longo dos tempos em que a escola teceu sua própria história.

A repercussão desse interesse pelos documentos escolares também refletiu na escola de educação infantil nas quais vêm ganhando cada vez mais espaço os documentos pedagógicos, ligados intimamente ao fazer docente com as crianças. No cerne desse interesse destaca-se atualmente a prática da documentação pedagógica que tem suas bases nos conceitos de profissional reflexivo e na produção de registros escolares, eixos de nossa discussão no item que se segue. 


\section{BASES DA DOCUMENTAÇÃO PEDAgógiCA: A PRÁticA REFLEXIVA A PARTIR DOS REGISTROS}

O conceito de profissional reflexivo não é recente, tem sido defendido por muitos autores e é tema de muito debate. A prática pedagógica reflexiva defende uma postura do professor que reconhece o saber da experiência aliado ao conhecimento teórico. Dewey foi um dos precursores a respeito do assunto, diferenciando o ato reflexivo do ato rotineiro. $\mathrm{O}$ ato rotineiro é guiado pelo impulso, tradição e autoridade. Já a ação reflexiva implica uma consideração ativa, persistente e cuidadosa. $\mathrm{O}$ ato reflexivo supõe planejamento que converte uma ação puramente repetitiva, cega e impulsiva, em ação inteligente (DEWEY, 1959, p. 26).

Pinazza (2007), amparada na perspectiva deweyana, ressalta o caráter investigativo da prática reflexiva quando o pensamento reflexivo se afasta de atos rotineiros e impulsivos. O processo de investigação existe quando se faz a formulação de uma indagação ou se reconhece um problema, ou seja, ocorre em situações de dúvidas nas quais o ato de pensar revela-se um meio de investigação. O contexto de uma investigação é sempre um todo mais amplo e não fatos isolados. Envolve o ato de pensar a partir da consciência de um problema, da previsão conjectural na tentativa de interpretar os elementos dados, o exame cuidadoso de todas as considerações possíveis, a elaboração de uma hipótese e por fim o traçado de plano de ação (PINAZZA, 2007).

Dewey (Apud ZEICHNER, 1993; PINAZZA, 2007) define três atitudes necessárias para a ação reflexiva: espírito aberto, interesse absorvido e responsabilidade. O espírito aberto refere-se à disposição de ouvir outras opiniões, atender alternativas. O interesse absorvido é o alto grau de envolvimento. A responsabilidade está em assumir e examinar as consequências de determinada ação. Pinazza (2007), a partir dos trabalhos de Dewey, sustenta que "no curso da atividade reflexiva, interpõem-se obrigatoriamente o interesse e o esforço pessoais. Compreendidos como complementares, ambos garantem a consecução de um processo de pensamento e ação" (p. 78).

Zeichner (1993) diz que os professores devem ser participantes ativos na formulação dos propósitos de seu trabalho e a prática reflexiva é o meio para isso. O professor como prático reflexivo reconhece a riqueza da experiência que reside na sua prática, não é consumidor das investigações feitas por aqueles que estão fora do contexto prático educativo.

Perrenoud (2002) defende a ideia de profissionalização do professor que não se limita ao domínio do saberes e valoriza a ampla autonomia dos profissionais, formando 
pessoas competentes que sabem o que devem fazer sem se restringirem a modelos, diretrizes ou normas padronizadas. Para o autor, um profissional integral deve exercer autonomia e responsabilidade pessoal e coletiva. Esse dois aspectos dependem de uma grande capacidade de refletir em e sobre a ação.

O mesmo autor atenta para o fato de não confundirmos a postura reflexiva do profissional com a reflexão episódica. Schön (1992) enriquece o diálogo ao considerar a complexidade e a reflexão constantes do professor relacionadas à sua prática e distingue dois processos: reflexão na ação e reflexão sobre a ação. A prática reflexiva da reflexão na ação é a reflexão realizada durante a ação. É o pensar, analisar, tomar atitudes no momento da ação. Refletir sobre a ação é diferente, é tomar nossa ação como objeto de reflexão. Perrenoud (2002) complementa as proposições de Schön, dizendo que pode haver na reflexão na ação uma reflexão sobre a ação, ou seja, durante a reflexão na ação o profissional reserva questões que não podem ser tratadas naquele momento, mas que serão retomadas na reflexão sobre a ação oportunamente. A reflexão sobre a ação prepara e antecipa o profissional para a reflexão na ação. Assim, tanto reflexão na ação e reflexão sobre a ação são processos complementares que estão no cerne da concepção do profissional reflexivo.

O professor reflexivo enquanto investigador de sua própria prática é defendido por Stenhouse (1998), e Perrenoud (2002) diz que este não para de repensar sua atuação docente fazendo da reflexão uma forma de identidade e de satisfação profissional. Na medida em que revivemos nossas práticas através da reflexão nos constituímos professores pesquisadores.

Schön (1992) aponta que a prática reflexiva deve integrar o contexto institucional e, assim como Dewey, estabelece uma relação da prática reflexiva com a observação e a documentação. A reflexão inclui observação e sugestão. A observação torna-se dados e as sugestões, ideias. Observação e sugestão são fatores correlativos e indispensáveis à reflexão. O pensamento reflexivo nos emancipa da ação impulsiva e rotineira, faz-nos capazes de dirigir nossas atividades com previsão e planejamento (DEWEY, 1959). Schön (1992) associa à prática reflexiva a documentação como forma de registrar e estabelecer a conexão entre passado e futuro.

É imprescindível pontuar que a defesa da prática reflexiva não diz respeito somente aos professores como sujeitos reflexivos, mas compreende a escola como locus integrado de reflexão partilhada. Freitas (2009), ao defender a "escola reflexiva" questiona a expressão "professores reflexivos" por entender que muitas das reformas nos planos formativos ou mesmo as políticas públicas focam suas intervenções na centralidade do professor sem considerar em quais condições de trabalho e de desenvolvimento profissional tais propostas 
estão sendo inseridas. O autor enfatiza que há um superdimensionamento do papel do professor como se só dependesse dele a sua prática reflexiva localizada no âmbito de seu fazer pedagógico para garantia de mudanças qualitativas na educação. O que não é considerado nesse princípio são os outros fatores que influem na qualidade da escola. Primeiramente é fundamental pensar sobre o lugar da escola e os diferentes profissionais que também a habitam, não sendo o professor o único ator, ou seja, o movimento de uma escola reflexiva envolve múltiplos atores sociais. Em segundo lugar é preciso problematizar em quais condições os professores são exigidos para a prática reflexiva, pois em geral as reformas educativas não garantem tempos e espaço para a reflexão. Também as propostas políticas não têm garantido tais condições, inclusive salariais, à equipe escolar com vistas a desenvolver um trabalho efetivamente reflexivo.

Fullan e Hargreaves (2001) também problematizam a prática reflexiva, apontando que desenvolvimentos reflexivos profundos são processos mais complexos e mais difíceis de serem alcançados. Envolve novos entendimentos e aperfeiçoamento das práticas, ou seja, o pensamento em si não se constitui novidade no campo educacional, mas como fazer dele um processo investigativo e que de fato sustente a reflexão potente é o ponto primordial e de mais raro alcance. Ao problematizarem a questão da reflexão na, pela e sobre a ação a partir do conceito de "prático reflexivo" de Schön, apontam alguns perigos que surgem dessa expressão que muitas vezes torna-se apenas um slogan e veste com uma nova linguagem aquilo que já fazemos ao invés de inspirar a fazer algo diferente. Isso se deve a três principais fatores: o primeiro, refere-se ao fato de os professores refletirem com poucos dados, sustentados apenas pelas impressões pessoais (que de fato são importantes, mas não bastam) e sem a participação dos alunos. A limitação da experiência pessoal na sala de aula, apontada como o segundo fator, é restritiva já que a reflexão profunda requer outros olhares e outras perspectivas. Isso significa o estabelecimento de uma rede comunicativa da equipe escolar que reflete em parceria. $\mathrm{O}$ terceiro aspecto evidencia a necessidade de refletirmos criticamente também sobre nossos propósitos e o contexto de ensino, analisando assim amplamente os aspectos que afetam direta ou indiretamente a sala de aula.

Certos da necessidade de constituição de um trabalho em equipe, Fullan e Hargreaves (2001) dialogam no sentido de uma escola que precisa valorizar as interações entre os professores:

... envolver os professores nas suas escolas, apoiar e valorizar aquilo que fazem e ajudá-los a trabalhar mais próximos uns dos outros, enquanto colegas, não são apenas gestos humanitários (que valem por si próprios), são 
questões que têm impacto sobre a qualidade do ensino e da aprendizagem nas nossas salas de aula (FULLAN; HARGREAVES, 2001, p. 17).

Gandini e Goldhaber (2002), inspiradas pelas ideias de Bruner ${ }^{5}$, também apontam que a prática reflexiva sustenta-se no intercâmbio de ideias entre os grupos de pares de professores. Uma vez que os pontos de vista são diferentes, pois não nos dissociamos enquanto educadores daquilo que somos enquanto pessoas, sujeitos históricos situados em um tempo e espaço específico e marcados por histórias de vida distintas, o diálogo com o outro é imprescindível e cria verdadeiras comunidades de aprendizes (GANDINI e GOLDHABER, 2002). As trocas de saberes entre professores e compartilhar teorias tornam possível transformar o mundo e é uma resposta às incertezas do trabalho docente (RINALDI, 2012).

Contudo, exercitar-se em um contexto reflexivo exige o enfrentamento de muitas realidades docentes com as quais os professores precisam lidar. Fullan e Hargreaves (2001) enumeram seis problemas a serem enfrentados para a concretização da mudança educativa: sobrecarga, isolamento, pensamento de grupo, competência não aproveitada, limitação do papel do professor e o problema da liderança, e soluções pobres e reformas falhadas.

As mudanças históricas que sofreu o trabalho do professor culminam com o acúmulo de função para além do ensino que envolve maior responsabilidade no nível da assistência social, tornando-se as escolas microcosmos de problemas sociais. Isso acarreta uma sobrecarga de trabalho piorada pela imposição de inovações saturadas que pouco incentivam o trabalho colaborativo. Compactuam para enfatizar o isolamento do trabalho docente enraizado na cultura docente e muitas vezes reforçado pela arquitetura, pelos horários escolares, mantido pela sobrecarga de trabalho e legitimado pela história (FULLAN; HARGREAVES, 2001, p. 23).

No intuito de resolver o problema do isolamento, nos anos 1990 a estratégia do aprofundamento da colegialidade foi foco de investimentos e ainda que se reconheça nela força poderosa de mudança, tal movimento a favor dela resultou em aspectos negativos. Não existe nada de automaticamente bom na colegialidade, ou seja, o pensamento de grupo pode ser apenas uma "colegialidade superficial" podendo representar mais restrição do que oportunidade de mudança.

${ }^{5}$ BRUNER, J. The culture of education. Cambridge, MA: Harvard University Press, 1986. 
A prática recorrente culmina também no não aproveitamento das competências dos professores e ainda na negligência da incompetência. O resultado do isolamento resulta nessas duas situações: qualquer coisa maravilhosa que o professor fizer ninguém dará por elas e qualquer que seja má também ninguém corrigirá. Nesse movimento é importante lutar para o trabalho em parceria para que os professores tenham acesso às ideias uns dos outros e por outro lado não tolerem os poucos que não correspondem.

As limitações do papel do professor e o problema da liderança é o quinto aspecto enfatizado por Fullan e Hargreaves (2001) que precisa ser ultrapassado rumo à perspectiva interativa escolar que supere os hiatos entre líderes e liderados, todos ocupando o lugar da responsabilidade pela educação. Por fim, as soluções pobres e reformas falhadas são resultantes de propostas que pesam nos professores por não considerarem sua contribuição como recurso válido.

Os autores, ao apontar esses problemas, defendem um plano formativo feito com os professores e não apenas para eles. Para isso é preciso resgatar quatro aspectos importantes que foram esquecidos: o propósito dos professores, a consideração do professor enquanto pessoa, o contexto do ensino real em que os professores trabalham e a cultura do ensino, ou seja, as relações de trabalho que são estabelecidas e constituem escolas integrais que atuam em parceria. Segundo Fullan e Hargreaves (2001, p. 71):

\footnotetext{
Ninguém é uma ilha. Não nos desenvolvemos isoladamente, mas sim através das nossas relações, especialmente as que mantemos com aqueles que são significativos para nós. Estes outros significativos funcionam como uma espécie de espelho do nosso desenvolvimento pessoal. Se os nossos locais de trabalho incluírem pessoas que são importantes para nós e que fazem parte dos nossos "outros significativos", eles terão uma forte capacidade - positiva ou negativa - para afetar o tipo de pessoa que somos e, portanto, o tipo de professor em que nos tornamos.
}

Dessa forma, o que é defendido são as culturas colaborativas onde todos os professores são líderes, no âmbito de uma escola que atua em parceria com seus diversos atores e acredita no poder da colaboração. Essa perspectiva também é defendida por Pinazza (2013) que, em pesquisa realizada, defende a perspectiva ecológica de desenvolvimento em contexto como base da formação continuada de uma equipe educativa de um Centro de Educação Infantil. A autora acredita em uma formação centrada na escola, que se valha das teorias vigentes, mas que também se aproprie do saber da prática dos educadores e do envolvimento da equipe como um todo que, ao refletir em parceria, promova a mudança qualitativa na escola. 
Resulta disso, a concepção de uma formação que compreende o desenvolvimento profissional em uma perspectiva de mudança, mas da mudança de cultura das práticas institucionais; uma formação que esteja comprometida diretamente com a identificação e o esforço de transformação dos padrões de trabalho que regem as ações no interior das instituições e para além delas e, por conseguinte, definem os processos individuais e coletivos (PINAZZA, 2013, p. 59).

No âmbito da escola reflexiva, a postura reflexiva exige um planejamento flexível e Dewey (1959), ao contrapor a educação tradicional da educação progressista, já falava da flexibilidade do planejamento. Em razão de a educação tradicional pressupor planos fechados com conteúdos e ações pré-definidas e enrijecidas poderia haver uma falsa impressão de que a ausência de planejamentos fosse postura ideal, contudo o autor defende não a extinção dos planos de trabalho, mas a planificação flexível que garanta a abertura para a experiência sem perder a solidez necessária para desenvolver a capacidade dos alunos. Corroborando o autor, Gandini e Goldhaber (2002) falam que um planejamento flexível deve respeitar as ideias das crianças sem, contudo, segui-las cegamente. Devemos:

... estudá-las a fim de determinar a quais delas podemos dar seguimento, e como elas poderiam ser encorajadas, em um contexto de planejamento flexível e de um currículo flexível (...). O currículo é visto como decorrente das observações dos professores sobre as ideias e os interesses das crianças, mas também é elaborado conforme o que os professores pensam que poderá contribuir para o crescimento delas (p. 154).

O professor deve ser um pesquisador de sua própria trajetória e das trajetórias das crianças, capaz de refletir continuamente e significar as experiências compartilhadas. Isso depende também de um contexto reflexivo que envolva a escola toda. Uma escola reflexiva sustenta o profissional docente e a produção de registros no âmbito pedagógico é defendida por muitos autores como instrumentos que balizam a postura reflexiva.

Freinet $(1998,2001)$ certamente foi um dos precursores dessa postura, pois refletia sobre o que fazia e dessa forma criou práticas inovadoras para a época, que utilizavam registros pedagógicos na atuação com as crianças de sua escola. Comprometido com uma escola para o povo, no caso a classe proletária, buscou atribuir maior sentido às experiências das crianças que fossem condizentes com suas realidades vivenciais. Para isso fez uso de novas práticas, entre elas algumas se destacam pela sua relação com registros escolares como a Imprensa escolar, o Jornal-mural, a Correspondência interescolar, o Livro da vida, o Texto livre, os Fichários.

Marques (2010), em seu estudo sobre a prática de registros e documentações em escolas de educação infantil, faz um levantamento sobre os trabalhos das últimas décadas que 
trazem a discussão sobre os registros e suas possibilidades de mudança de paradigma em relação à compreensão da prática pedagógica, à formação de professores e à profissionalidade docente. Enumera os conceitos de professor reflexivo, professor pesquisador, professor intelectual crítico-reflexivo, ressaltando aspectos da profissionalização da prática docente ao se basear em autores internacionais e nacionais como Schön, Nóvoa, Zabalza e Pimenta. A autora cita ainda o crescente interesse de estudos sobre a organização da escola e a formação contínua de professores nos quais aparecem os registros de práticas que:

... podem ser caracterizados como materiais autobiográficos, contextualizado em um cenário de valorização da experiência como espaço de produção de saberes e de formação contínua, de reposicionamentos da dimensão pessoal na profissionalidade do educador, e de percepção da complexidade da prática pedagógica e da reflexão como componente fundamental do trabalho docente (MARQUES, 2010, p. 98).

Corroborando a ideia expressa na frase transcrita, autores de diferentes países são chamados ao diálogo no que tange à valorização dos registros de professores e a suas possibilidades de práticas reflexivas do fazer pedagógico.

Zabalza $(1994,2004)$ sustenta sua discussão a partir dos registros de professores na modalidade de diários. Segundo o autor, os diários são as narrativas dos professores, não precisam ser contidos necessariamente de registros de atividades diárias, mas devem ter continuidade que permite ao professor "revisar elementos de seu mundo pessoal que frequentemente permanecem ocultos à sua própria percepção enquanto está envolvido nas ações cotidianas de trabalho" (ZABALZA, 2004, p. 17). O aspecto contínuo dos registros no formato de diários que evidencia o pensamento do professor, definido por caráter histórico e longitudinal, é uma das quatro potencialidades expressivas que os diários possibilitam, além da implicação na escrita, implicação com a reflexão (diálogo do professor consigo mesmo) e a integração das vertentes expressivas (reflexão sobre si próprio) e referenciais (elaboração dos planejamentos de aula).

Para além das potencialidades expressivas, o autor enumera o impacto formativo dos diários que possibilita o acesso ao mundo pessoal do professor, explicita dilemas em relação à atuação profissional, proporciona a avaliação do processo e o desenvolvimento profissional permanente. Sobre este último, enfatiza que a simples prática não melhora substancialmente a qualidade do exercício profissional, por isso a necessidade de aliar teoria à prática e buscar instrumentos de coleta e análise de informações referentes às práticas, permitindo revisitá-las e reajustá-las. Aponta não apenas os diários, mas também outras formas de documentações como recursos valiosos para a prática reflexiva e melhoria da atividade dos professores. 
Zabalza (1994) diz ainda que o professor constantemente expõe, explica e interpreta na medida em que reconstrói a experiência a partir dos diários de aula, contudo, também reconhece o esforço necessário para produzir os registros, que demandam muita dedicação. Schenkel (2005), ao falar dos registros nos moldes de portfólios, também enfatiza a necessidade de condições de trabalho para que o professor exerça a postura reflexiva por meio das relações entre pensar e agir, entre a teoria e a prática. Para isso destaca uma escola reflexiva que exige profissionais inquietos, em constante formação, capazes de trazer questionamentos para criarem e recriarem suas ações.

Na mesma direção posiciona-se Warschauer (1993, 2001) com relação às condições de espaço e tempo necessárias para o exercício da prática reflexiva. A autora concorda com os autores já citados na defesa da produção de registros das práticas pedagógicas como recursos para o ato de refletir, planejar e avaliar o percurso. Ressalta especialmente os registros escritos como oportunidades formativas, fruto do trabalho coletivo na medida em que podem envolver todo o contexto escolar na reflexão sobre as práticas. Evidencia ainda a potencialidade de os registros dos professores irem contra a memória oficial, ou seja, se constituírem no campo de uma contra-memória, já que não fazem parte das documentações oficiais, porém colaboram significativamente para a construção da história das instituições. Para a elaboração dos registros, sua análise e reflexão a autora aponta a necessidade de distanciamento necessário para o ato reflexivo que só é possível quando há garantidas condições de trabalho para este exercício.

O trabalho organizado por Paige-Smith e Craft (2010) a respeito da prática reflexiva na educação infantil amplia a discussão a respeito das garantias necessárias para o exercício da prática reflexiva para outros desafios, além das condições de trabalho, especialmente na forma de tempo e espaço, indiscutivelmente necessários. Uma vez que se reflete é preciso ampliar os interlocutores e pensar como e com quem as experiências das crianças são compartilhadas, ou seja, pensar sobre o aspecto comunicativo que a prática reflexiva pode oferecer. Há que se reconhecer que desenvolver a prática reflexiva não é fácil nem é algo direto, por isso é preciso que se encontre um equilíbrio entre as expectativas de aprendizagem por meio da reflexão, o tempo e a experiência envolvidos, ou seja, é preciso ser realista sobre quanto a reflexão pode influenciar nossa prática, por isso o desafio constante é manter-se aberto e criar condições de debates para construir junto com o outro novas compreensões e ideias.

Sobre essa abertura ao diálogo, essa rede comunicativa, a obra dessas autoras traz uma perspectiva bastante relevante no que tange aos níveis de interação e envolvimento com 
o outro, pois embora a prática reflexiva ofereça um feedback voltado à melhoria da prática é importante que a reflexão seja compartilhada, vista pelo olhar dos outros (PAIGE-SMITH; CRAFT, 2010, p. 37). Segundo as autoras é preciso criar uma ampla rede de diálogo que envolva os professores, demais profissionais das escolas, os pais, as famílias e a comunidade como um todo.

Moss (2010) nomeia essa proposta das autoras como a criação de uma "comunidade de prática" que necessariamente se constitui em um processo dialógico, muitas vezes consigo mesmo, mas também com os outros. Ao citar Rinaldi (2005), lembra que o ambiente do diálogo deve ser mais que apenas trocas de pontos de vista na medida em que tem a capacidade para a transformação e neste sentido está em jogo a valorização da incerteza. Incerteza aqui não entendida como fraqueza e sim como o reconhecimento de um estado permanente de mudança que encontra sua identidade no diálogo.

Paige-Smith e Craft (2010), ao se dedicarem a pensar sobre a prática reflexiva na educação infantil, enumeram, citando Pollard (2002), sete características necessárias para a prática reflexiva na educação: 1- enfoque ativo nas metas, como são abordadas e nas consequências desse processo; 2- compromisso com ciclo contínuo de monitoramento da prática, avaliando-a e revisando-a; 3- enfoque nas opiniões fundamentadas sobre a prática; 4atitude aberta, responsável e inclusiva; 5- capacidade de remoldar a prática a partir da reflexão própria e também baseada em outras pesquisas; 6- diálogo com os outros colegas; 7capacidade de mediar e a adaptar modelos desenvolvidos fora da escola para a prática, fazendo julgamentos reflexivos sobre quando inovar ou defender as práticas existentes.

A partir dessas características e sustentadas nos escritos de diferentes autores, PaigeSmith e Craft (2010) conceituam o processo da prática reflexiva ao dizerem que vai do literal e imediato para o abstrato/conceitual e teórico.

Transitar do imediato ao abstrato e teórico requer, na visão das autoras, recursos sustentados pela documentação. As documentações instrumentalizam a prática reflexiva na medida em que a partir delas é possível fazer previsões, planejar o trabalho, observar com maior atenção as situações vividas com as crianças tornando visíveis os processos de aprendizagem e, sobretudo, por meio da documentação a participação é encorajada no sentido de um apoio holístico da aprendizagem que envolve os profissionais da educação, as crianças, as famílias e a comunidade. Assim a documentação não é apenas um meio de relatar as experiências, mas ela possibilita o diálogo e a interação de diferentes esferas envolvidas na vida das crianças. Em outras palavras, ela é a fonte de evidências para o exercício da prática reflexiva e democrática. 
Moss (2010) também defende a prática reflexiva amplamente na direção da criação de uma comunidade democrática. Para isso é preciso pensar nas condições que sustentam a prática reflexiva, que vão desde aquelas pragmáticas como o tempo e o espaço, mas também uma força de trabalho qualificada. A qualidade dos professores está ligada à sua capacidade de sentir-se confortável com o diálogo e a subjetividade, valorizar as incertezas e a postura curiosa, e disposta a romper com abordagens passivas. É preciso que seja um pesquisador de sua própria prática e apresentar o pensamento crítico tendo a documentação pedagógica como ferramenta para isso.

Ao tentar responder a que propósito pode servir a prática reflexiva, Moss (2010) defende que é ela que possibilita a compreensão mais profunda da aprendizagem e aproxima a teoria, a prática e a pesquisa. Em sua abordagem mais fundamental, a prática reflexiva contribui significativamente para:

Tornar as instituições de educação infantil lugares de prática política democrática e ética, mais do que de prática técnica (Dahlberg e Moss, 2005), oferecendo oportunidades para discutir "tudo com todos" (p. 17).

Especialmente sobre esse "todos", refere-se também à possibilidade de nele serem incluídos os administradores e elaboradores das políticas que poderiam participar da reflexão sobre a prática, revertendo a separação que há entre quem está com as crianças cotidianamente e quem exerce o poder político. Por isso, igualmente importante é o cuidado de não tornar a prática reflexiva apenas mais uma tecnologia na vida dos educadores quando estes são considerados meros técnicos:

A prática reflexiva pressupõe determinadas compreensões, qualidade e valores. Requer certas condições materiais, no que toca à formação dos profissionais assim como à garantia de que haja tempo para a prática reflexiva na vida cotidiana. Requer uma certa ética ao relacionar-se consigo mesmo e com os outros: uma ética dialógica e democrática, cuidadosa e respeitosa, que ouça e esteja aberta ao outro, ao múltiplo. É uma jornada longa e difícil, sem fim óbvio em vista, mas na qual vale a pena embarcar (p. $18)$.

A obra de Madalena Freire (1983) destaca-se ao publicar registros de sua prática como professora e defender uma pedagogia que considere as crianças como autoras de seus processos de aprendizagem, sendo o professor um organizador de sentido que observa, colhe os dados e trabalha em cima deles em uma postura de total respeito ao educando. É preciso um professor reflexivo com autonomia para criar e recriar o seu fazer pedagógico que tem como estrutura os registros que produz com as crianças ou individualmente. 
A autora fala especialmente dos registros escritos (M. FREIRE, 1996), enfatiza o esforço necessário e a persistência para tornar o ato de escrever uma libertação, já que instrumentaliza o pensar. Compreender a potência da escrita reflexiva do professor como recurso de conhecer a si mesmo, o outro e o mundo não é fácil porque requer um redimensionamento da linguagem oral com a escrita que nos foi privado, segundo a trajetória que abrange grande parte dos professores de alfabetização e inserção na cultura letrada que não os convida à leitura de mundo e despreza a escrita como um potente instrumento para isso, restringindo-a ao ensinamento de códigos.

Esse resgate do professor como sujeito escritor tem como base a postura reflexiva. Considera os registros por ele produzidos, a relação entre teoria e prática, a produção de marcas e a relação espaço-temporal que volta ao passado enquanto se constrói o presente. No cerne dessa postura reflexiva, o professor não busca somente respostas, mas principalmente identifica perguntas de seu processo com as crianças que vai se transformando no decorrer de suas reflexões e reconfigura suas ações continuamente.

A defesa da estreita relação entre a prática reflexiva e a produção e análise de registros aparece explicitada nos documentos legais. O Referencial Curricular Nacional para a Educação Infantil - RCNEI de 1998 (documento não normativo, mas que obedece às exigências legais impostas pela LDBEN no. 9394/96), elaborado pelo MEC para orientar a elaboração dos currículos das instituições de educação infantil, aponta a prática reflexiva ao dizer do caráter polivalente do professor de educação infantil que:

... demanda, por sua vez, uma formação bastante ampla do profissional que deve tornar-se, ele também, um aprendiz, refletindo constantemente sobre sua prática, debatendo com seus pares, dialogando com as famílias e a comunidade e buscando informações necessárias para o trabalho que desenvolve. São instrumentos essenciais para a reflexão sobre a prática direta com as crianças a observação, o registro, o planejamento e a avaliação (RCNEI, v.1, p. 41).

No mesmo documento, indicam-se a observação e o registro como estratégias para a avaliação formativa no qual é ressaltada a importância do registro para apoio da prática que pode se concretizar principalmente por meio da escrita, mas também por gravações em áudio ou vídeo, fotografias e produções das crianças:

A observação e o registro se constituem nos principais instrumentos de que o professor dispõe para apoiar sua prática. Por meio deles o professor pode registrar, contextualmente, os processos de aprendizagem das crianças; a qualidade das interações estabelecidas com outras crianças, funcionários e com o professor e acompanhar os processos de desenvolvimento obtendo informações sobre as experiências das crianças na instituição. Esta 
observação e seu registro fornecem aos professores uma visão integral das crianças ao mesmo tempo que revelam suas particularidades. São várias as maneiras pelas quais a observação pode ser registrada pelos professores. A escrita é, sem dúvida, a mais comum e acessível. O registro diário de suas observações, impressões, ideias, etc. pode compor um rico material de reflexão e ajuda para o planejamento educativo. Outras formas de registro também podem ser consideradas, como a gravação em áudio e vídeo; produções das crianças ao longo do tempo; fotografias, etc (RCNEI, v. 1, p. 58).

As Diretrizes Curriculares Nacionais para a Educação Infantil (que tem sua primeira versão em 1999, é revista em 2009 e publicada em 2010), documento normativo dessa modalidade de ensino no Brasil, prevê no que se refere à avaliação a utilização de registros dos adultos e das crianças como recursos avaliativos (p. 29, grifo nosso):

As instituições de Educação Infantil devem criar procedimentos para acompanhamento do trabalho pedagógico e para avaliação do desenvolvimento das crianças, sem objetivo de seleção, promoção ou classificação, garantindo:

- A observação crítica e criativa das atividades, das brincadeiras e interações das crianças no cotidiano;

- Utilização de múltiplos registros realizados por adultos e crianças (relatórios, fotografias, desenhos, álbuns etc.);

- A continuidade dos processos de aprendizagens por meio da criação de estratégias adequadas aos diferentes momentos de transição vividos pela criança (transição casa/instituição de Educação Infantil, transições no interior da instituição, transição creche/pré-escola e transição préescola/Ensino Fundamental);

- Documentação específica que permita às famílias conhecer o trabalho da instituição junto às crianças e os processos de desenvolvimento e aprendizagem da criança na Educação Infantil;

- A não retenção das crianças na Educação Infantil (BRASIL, 2010).

Conforme o exposto, os registros são instrumentos para a prática reflexiva, postura fundamental na prática docente. $\mathrm{O}$ uso que se pode fazer deles num constante exercício de rever a atuação com as crianças, compreender os percursos trilhados a partir do olhar atento, interpretação e reflexão do contexto, estrutura a discussão sobre documentação pedagógica que será abordada a seguir. 


\title{
4. ABORDAGEM DA DOCUMENTAÇÃO PEDAGÓGICA
}

\author{
De fato, aquilo que documentamos é um senso da busca que crianças \\ e adultos fazem juntos pelo significado e pela vida.
}

Rinaldi, 2012

O tema da documentação pedagógica vem ganhando espaço cada vez maior, especialmente através dos trabalhos divulgados das escolas infantis do norte da Itália. Reggio Emilia é certamente a mais conhecida entre os brasileiros por sua concepção de educação infantil que envolve a documentação pedagógica como um de seus pilares, mas é importante dizer que quando se faz referência à abordagem italiana para a educação infantil outras cidades também se destacam, entre elas: Parma, Firenze, Bolonha e San Miniato.

O aporte teórico utilizado nesta pesquisa sobre documentação pedagógica utiliza a perspectiva da abordagem italiana (que envolve o conjunto de práticas características do norte do país, não se restringindo apenas à cidade de Reggio Emilia) e a perspectiva da Associação Criança, liderada pela professora Júlia Oliveira-Formosinho em Portugal, que também evidencia a inspiração no trabalho com Documentação nas ideias de Loris Malaguzzi ${ }^{6}$.

Dahlberg, Moss e Pence (2003) ressaltam que apesar da prática documentativa estar ganhando maior espaço, atualmente ela não é tão recente e cita Elsa Köhler e John Dewey como precursores da postura reflexiva que problematiza a prática pedagógica tendo como cerne a comunicação, a interação e a observação - eixos da documentação pedagógica. Barbosa (2012) defende a expressão 'documentação pedagógica' como potente para produzir outros sentidos e Kohan (Apud BARBOSA, 2012, p. 1) fala de um novo início para a educação:

A educação é um desses lugares onde parece que já não há nada mais a dizer, onde se disse (quase) tudo e onde, de tanto dizer o mesmo, as palavras parecem cansadas, quase vazias, sem nada dentro. (...) No entanto, com toda essa dificuldade para falar com sentido - que é também uma dificuldade para pensar e trabalhar - , há educadores que ainda apostam na infância, na revolução, na criação. Educadores que criam, revolucionam e se alçam a um

\footnotetext{
${ }^{6}$ Loris Malaguzzi foi o idealizador das escolas infantis em Reggio Emilia, que valorizava a produção dos registros dos professores e a partir da prática reflexiva em parceria. Ele inicia o trabalho com documentação pedagógica aspecto relevante ainda hoje nas escolas de Reggio.
} 
devir infantil nos contextos mais adversos, inócuos, vazios. E inclusive falam quando parece que não há nada mais a dizer. E não deixam de inventar palavras ou reinventam as que já existem, para dizê-las de outra maneira, para sacudi-las de sua modorra.

A prática da documentação pedagógica pode assim sacudir as palavras que já existem e (re)significar práticas educativas já cansadas no meio educativo.

Discutimos no item anterior a postura reflexiva do professor e o uso de registros que o instrumentaliza nesta prática. Essas duas vertentes estão diretamente relacionadas à concepção do trabalho com documentação pedagógica, pois esta não pode ser feita sem um professor que esteja em constante diálogo consigo mesmo e com os outros dentro de um processo contínuo reflexivo que utiliza como base seus registros das práticas com as crianças. Como já apontado neste trabalho, a preocupação ao longo da história com a coleta, análise e cultivo de documentos reflete-se nas ações da instituição escolar que passa a se preocupar com os materiais que produz e reconhece neles fontes importantes para compreensão da cultura da escola. Os documentos produzidos pelos professores ganham maior relevância, especialmente a partir do conceito do profissional reflexivo que utiliza seus registros para repensar a sua prática pedagógica.

Rinaldi (2012), ao defender a documentação pedagógica como ferramenta que possibilita a reflexão, discute brevemente o conceito no campo pedagógico e a ampliação do seu sentido:

O conceito de documentação como uma coleção de documentos utilizados para demonstrar a verdade de um fato ou confirmar uma tese é historicamente correlato ao nascimento e à evolução do pensamento científico, e a uma conceituação do conhecimento como entidade objetiva e passível de demonstração. Portanto, ele é vinculado a um determinado período histórico e as profundas razões de natureza cultural, social e política, que não examinarei aqui. Em vez disso considero interessante ressaltar como o conceito de documentação, que só recentemente ingressou no ambiente acadêmico, mais especificamente na esfera didático-pedagógica, sofreu modificações substanciais que, em parte, alteram sua definição. Nesse contexto, a documentação é interpretada e utilizada por seu valor como ferramenta para recordar; isto é, como possibilidade de reflexão (p. 120).

Essa indissociável relação entre a prática da documentação pedagógica e a postura reflexiva é o ponto fundamental de nossa discussão, sustentada por diversos autores que têm se dedicado ao assunto. No entanto, antes de nos aprofundarmos sobre o tema é importante fazer uma breve diferenciação dos termos Documentação e Documentação Pedagógica entendidos nesta pesquisa. É comum os dois termos se confundirem e 
restringirem a compreensão de apenas coleções de documentos produzidos nos contextos escolares.

Helm e Beneke (2005) claramente diferenciam esses dois termos. Elas defendem a documentação como uma coleção de registros dos educadores que os ajudam a conduzir os trabalhos com as crianças e podem se materializar de diversas formas: fotografias, anotações, exposições, registros em áudio, desenhos das crianças, entre outros. A coleta desses dados constitui-se na visão das autoras uma "documentação crua" que só se torna uma verdadeira documentação quando reorganizada e compartilhada com outras pessoas, sejam elas os pais, educadores ou membros da comunidade. Documentação, segundo elas, está intimamente ligada à memória, à comunicação e à planificação do trabalho docente, contudo, esclarecem a diferenciação entre documentação e documentação pedagógica. Esta última é vinculada aos trabalhos desenvolvidos nas escolas de Reggio Emilia e incluiriam uma reunião de documentações que é estudada com o propósito de compreender os processos de aprendizagem das crianças.

Ainda que o conceito de documentação pedagógica tenha sua raiz na coleta de registros e sua análise, ele pressupõe um processo reflexivo de seleção, organização e interpretação. Não deve ser entendida como um evento esporádico e isolado, um registro final ou uma coleção de documentos, porque vista desse modo está ligada a uma concepção de conhecimento mensurável e capaz de ser demonstrado. Contrariamente a essa concepção, entende-se a documentação pedagógica como a essência da reflexão, um processo de construção de significado (AZEVEDO, 2009; DAHLBERG; MOSS; PENCE, 2003). A documentação pedagógica não busca uma verdade objetiva que pode ser registrada fielmente, ela é uma representação, uma interpretação de sentido das experiências das crianças que pode ser constantemente reinterpretada, por isso não há apenas uma história verdadeira (HOYUELOS, 2006), uma vez que é sempre seletiva, parcial e contextual (DAHLBERG; MOSS; PENCE, 2003).

A ação reflexiva que a documentação pedagógica proporciona auxilia a compreender os processos que os educadores vivenciam com as crianças e também são instrumentos para 'auto-reflexividade' do professor, já que no processo reflexivo ele percebe suas concepções e interpreta suas subjetividades. Monti (2001) destaca o aspecto metacognitivo da documentação como um modo de o educador entrar em seu próprio mundo para examiná-lo reconstruindo o seu saber e fazendo-se compreender a partir da experiência. 
Davoli (2011) define a documentação como argumentação, narração e explicação de processos, situações e experiências que implicam interpretação. Interpretar significa colocar todos os dados coletados em relação entre as esferas da teoria e da prática para a construção de novos conhecimentos. Este aspecto formativo da construção de um novo saber também é apontado por Barbosa (2012) quando fala dos diálogos em que os educadores são colocados a fazer, devendo estar abertos à mudança e à articulação dos diferentes pontos de vista:

A documentação pedagógica pode constituir-se em uma poderosa e produtiva ferramenta de formação (no sentido que Foucault dá aos instrumentos que ajudam a pensar), tendo em vista que ela nos convida a pensar de outro modo sobre o que sabemos e o que fazemos em nosso cotidiano na escola infantil. A adoção de uma prática de documentação como uma perspectiva pedagógica não tradicional requer necessariamente uma abertura para a mudança e a inclusão de diferentes pontos de vista. Nesse sentido, podemos falar na dimensão formativa da documentação pedagógica: a documentação pode ser uma ferramenta potente porque ela não apenas estabelece uma nova relação entre os educadores e as crianças, mas também oportuniza outra maneira de trabalhar entre os adultos. Ela se constitui como uma produção pedagógica e como importante instrumento de trabalho. Documentar pode ser ainda um importante momento de crescimento profissional, de qualificação do serviço e da construção de condições de trabalho adequadas (BARBOSA, 2012, p. 3).

Reiterando a fala da autora, o que podemos dizer sobre a documentação pedagógica é que ela oferece uma prática reflexiva em parceria de todos os envolvidos na educação das crianças, o que Mignola (2001) chamará de ocupar-se ao invés de preocupar-se. Na escola tradicional o trabalho concentra-se nas programações reduzidas aos meros trabalhos burocráticos nos quais os educadores estão sempre "pré-ocupados" em documentar métodos, esquecendo-se dos processos e das incertezas dos percursos. Quando estamos "pré-ocupados" com qualquer coisa não estamos de fato envolvidos e ocupados dela, ou seja, não estamos dedicados o suficiente e entregues ao processo. Para que nos ocupemos de algo é preciso estar em relação com o outro, ocupando-se dele e reconhecendo-o, mas também ocupando-se de si mesmo para se colocar em relação ao outro. As documentações pedagógicas servem para reconstruir percursos, reelaborar hipóteses e teorias, reencontrar-se com as próprias emoções (MIGNOLA, 2001, p. 25) e no exercício desse compartilhar os processos em um intercâmbio ativo de parceria constituem-se as comunidades de aprendizes (GANDINI ; GOLDHABER, 2002).

As experiências com documentação pedagógica no âmbito da Pedagogia-emParticipação ampliam o sentido das comunidades de aprendizes para além da metaaprendizagem das crianças e dos educadores, sendo um processo central para os formadores 
desses profissionais (formadores em contexto, supervisores, diretores, coordenadores pedagógicos). Oliveira-Formosinho (2011) fala de uma:

[...] triangulação interativa entre intenções, ações e realizações que sustentam a práxis e promovem o movimento triangular de (re)criação da pedagogia como ação fecundada na teoria e sustentada num sistema de crenças (p. 117).

Documentar para se colocar em relação oferece oportunidades de formação e autoformação ao traduzir as ações em pensamento, o pensamento em forma visível, interpretativa e comunicativa (MALAVASI; ZOCCATELLI, 2012).

Hoyuelos (2006) fala da possibilidade de refletir em parceria que a documentação pedagógica oferece aos educadores, ao lutar contra a possibilidade consciente ou inconsciente de fazerem interpretações automáticas, e cita Bruner, que propõe três antídotos contra essa inconsistência narrativa: o contraste, a confrontação e a metacognição. Ao se escutar duas explicações contrárias de um mesmo acontecimento a confrontação leva à metacognição, processo em que o objeto do pensamento é o próprio pensamento. Contraste e confrontação despertam a consciência sobre a relatividade do conhecimento e assim o objetivo da metacognição é criar formas alternativas de criação da realidade. Em outras palavras, a prática reflexiva em parceria que a documentação pedagógica pode proporcionar não traz verdades absolutas e sim parcialidades igualmente legítimas que integram o conjunto de educadores reflexivos em um planejamento flexível.

\subsection{Documentação pedagógica e pedagogia da escuta}

Progettazione é o termo utilizado pela abordagem italiana para descrever este currículo flexível que prevê um constante (re)pensar sobre os planejamentos com as crianças, que é viabilizado por meio da documentação pedagógica. Segundo Malavasi e Zoccatelli (2012) progettare significa utilizar as documentações pedagógicas como automonitoramento que acompanha e orienta o fazer educativo em um processo de realização, verificação, avaliação e autoavaliação para replanejar. Essa reflexão em processo e contínua está sustentada em um planejamento flexível que o é porque está em constante diálogo com o outro. Esta relação dialética é a base da Pedagogia da Escuta. 
Na experiência italiana para educação da infância a escuta não é simplesmente uma técnica e sim uma forma de interação com o outro garantindo a visibilidade de quem escuta e de quem é escutado. Kinney e Wharton (2009) ressaltam o entendimento profundo de escuta como cultura e abordagem para a vida que revê as relações de poder entre adultos e crianças. Azevedo (2009), citando Rinaldi (2005), ressalta essa ideia cultural da escuta que também é simultaneamente política e ética. É preciso olhar com olhos de quem escuta entendendo o escutar como verbo ativo que interpreta e dá sentido às mensagens dos outros (AZEVEDO, 2009; AZEVEDO e SOUZA, 2010).

Essas definições coadunam ao que Dahlberg, Moss e Pence (2003) chamam da ética de um encontro. Azevedo e Souza (2010, Apud Oliveira-Formosinho e Azevedo, 2010), ao falarem sobre a Pedagogia-em-Participação salientam que a documentação requer que o adulto suspenda seus saberes para escutar os sinais das crianças, "suspender o fazer, o imparável activismo a que as situações nos obrigam se não decidirmos controlá-las; suspender o fazer para ver, escrever e fotografar como forma de perceber a criança; registar o que vê num formato disponível com a técnica acessível” (p. 9).

Ao falarmos da escuta das crianças, nos referimos à escuta de todas as linguagens que elas são capazes de expressar, registrando-as e as tornando visíveis. Nas palavras de Rinaldi (2012):

Escuta, portanto, como metáfora para a abertura e a sensibilidade de ouvir e ser ouvido - ouvir não somente com as orelhas, mas com todos os nossos sentidos (visão, tato, olfato, paladar, audição e também direção). Escuta das cem, das mil linguagens, símbolos e códigos que usamos para nos expressar e nos comunicar, e com os quais a vida expressa a si mesma e se comunica com aqueles que sabem ouvir (p. 124).

A escuta, contudo, não é fácil, exige a suspensão de nossas ideias e pré-conceitos, só se efetiva quando deixamos de lado nossos julgamentos e nos colocamos abertos à mudança (RINALDI, 2012; AZEVEDO e SOUSA, 2010). Exige, portanto, um contexto de escuta, uma sensibilidade que precisa de tempo. A escuta legitima e dá visibilidade, porém requer tempo, tempo este defendido por Hoyuelos (2006) para ser investido com muita qualidade traduzindo-se em paciência e disponibilidade para que o adulto seja capaz de compreender o tempo da criança e escutá-la. Trata-se de um tempo não cronológico, “... um tempo cheio de silêncios, de longas pausas, um tempo interior (RINALDI, 2012, p. 124)”. Esse tempo é possuído pelas crianças, o tempo rarefeito, curioso, suspenso e generoso (RINALDI, 2012). 
Escuta envolve ainda emoção e interpretação. Azevedo (2009) defende uma Pedagogia da Escuta que envolva uma prática educativa que ouça mais as crianças ao invés de falar e diz que:

A documentação, mais do que respostas ao mundo educativo, propõe cem perguntas, cem interrogações, cem hipóteses e cem teses para os cem direitos da infância. Cem formas de sair de uma imagem pobre e simplificada da infância para através de projetos concretos se converterem numa declaração testemunhal de um fim ético - os direitos das crianças (p. 39).

Na perspectiva da Pedagogia-em-Participação, a documentação pedagógica é um mediador das múltiplas escutas, não é possível documentar sem escutar e observar, contudo a observação deve ser entendida como diversas possibilidades em ação. Para observar é preciso ter a mente aberta aos caminhos possíveis (AZEVEDO, 2009). No mesmo sentido Dahlberg, Moss e Pence (2003) são enfáticos quando afirmam que documentação pedagógica não é observação da criança no entendimento da observação como avaliação do desenvolvimento psicológico, é um processo de visibilidade da criança que desafia os educadores à objetividade com que a observação muitas vezes é praticada. Observar na perspectiva documentativa envolve a compreensão de múltiplos significados presentes nas relações do educador com as crianças em processos subjetivos, visto que estão em constante condição de serem (re)interpretados.

Malavasi e Zoccatelli (2012) apontam a íntima relação entre interpretação, subjetividade e intersubjetividade. Na prática da documentação pedagógica partimos sempre de nossa subjetividade, nossa parcialidade para a reconstrução dos significados. As subjetividades se alimentam nas relações e na intersubjetividades. Como colocam as autoras, o prefixo latino "inter" exprime reciprocidade, comunhão, união, posição intermediada entre dois objetos. A escola infantil é por excelência um lugar de relação e troca de saberes, dimensão constante de subjetividades e intersubjetividades que são possíveis por meio da escuta interpretativa, porém nunca definitiva, das crianças pelos educadores.

Essa perspectiva que reúne documentação pedagógica e escuta assenta-se na concepção de uma prática educativa que está em constante movimento de relações intersubjetivas alimentadas pelos contextos interpretativos. Esse processo envolve um percurso não definido previamente, desloca a relação pedagógica transmissiva para a de construção de significados que tem no educador um construtor de experiências, sustentado pela sua competência de se fazer perguntas e elaborar hipóteses interpretativas (MALAVASI; ZOCCATELLI, 2012). 
Sobre o contexto das perguntas na relação pedagógica, Malavasi e Zoccatelli (2012) ressaltam a importância das boas perguntas que segundo elas podem ser definidas pela sua capacidade de abertura para o aprofundamento e são definidas a partir de três pontos de vista:

1. Como uma atitude do adulto que não objetiva respostas imediatas, mas abre novos horizontes para os percursos de aprendizagens das crianças;

2. Como uma atitude reflexiva do educador se rever e construir novos níveis de compreensão de um percurso vivido;

3. Como estratégia de pesquisa que se contrapõe à ideia de ensino linear e sequencial, ou seja, perguntas que guiam o processo de aprendizagem.

Aprender a se fazer perguntas é um processo difícil e complexo pela nossa tendência a simplificar as situações ao invés de problematizá-las, exige um grupo que atue em parceria e um tempo previsto à reflexão para que seja possível sair das perguntas retóricas e seguir o contexto de perguntas abertas e potentes. É preciso uma atitude que saia da postura ansiosa em dar respostas conclusivas e para isso é essencial dar-se tempo para a elaboração, reelaboração das perguntas que não têm respostas definitivas, são sempre parciais, contextuais e fruto das interpretações dos envolvidos no processo de aprendizagem.

Gandini e Goldhaber (2002), Malavasi e Zoccatelli (2012) e Azevedo (2009) (citando Oliveira-Formosinho, 2008) adotam o contexto das perguntas em ciclos de investigação dento do processo da documentação pedagógica. Gandini e Goldhaber (2002) traduzem no esquema a seguir (imagem 1) o processo de documentação pedagógica que se inicia com uma ou mais perguntas, a partir das observações, registro e coleta de instrumentos (que devem levar em consideração o contexto e o cenário real) parte-se para organização desses dados para posterior análise e interpretação que reformula as perguntas iniciais e projeta as próximas ações dentro um planejamento flexível. 


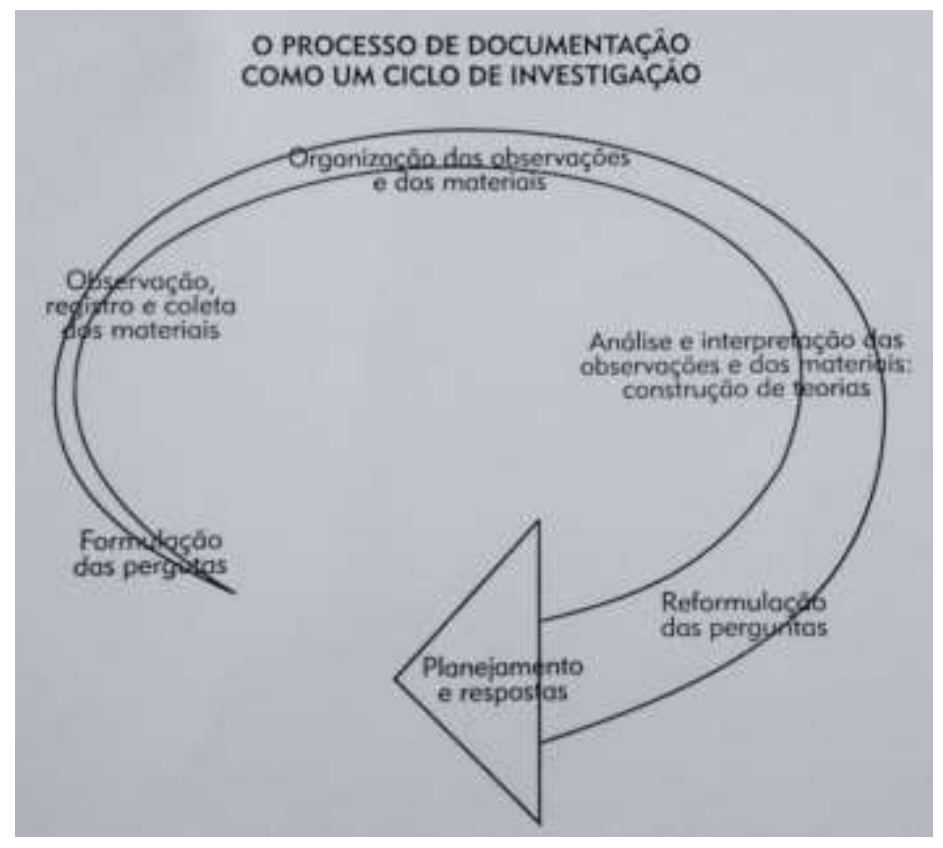

Figura 1- O processo de documentação pedagógica como ciclo de investigação (Fonte:

GANDINI e GOLDHABER, 2002, p. 162).

Malavasi e Zoccatelli (2012) também sugerem um ciclo do processo documentativo que envolve intenções, formulação de perguntas, projeção. Já Azevedo (2009) incorpora as perguntas dentro do esquema proposto pela Pedagogia-em-Participação:

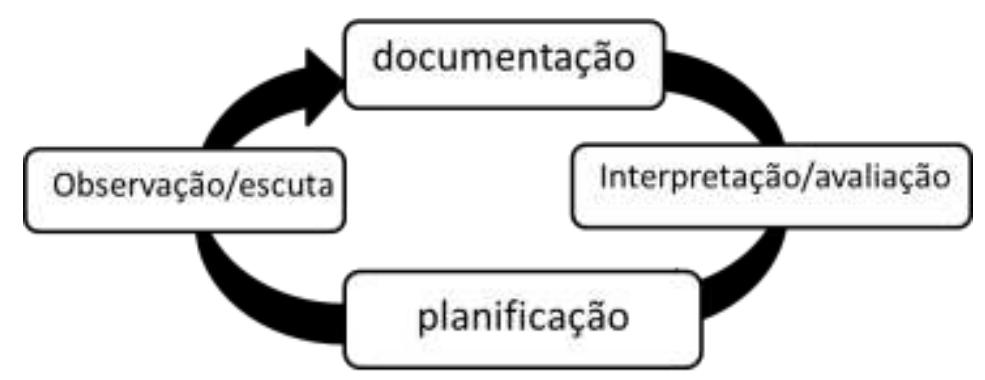

Figura 2 - Movimentos em espiral entre documentação, interpretação/avaliação, planificação e observação/escuta (Fonte: AZEVEDO, 2009, p. 9).

Sob outra perspectiva, as perguntas também podem auxiliar na organização de um projeto de documentação pedagógica. Benzoni (2001) e Malavasi e Zoccatelli (2012), inspirados pela cultura jornalística anglo-saxônica sugerem perguntas-chave para o percurso documentativo (who, what, when, where, why) e acrescentam mais um (with). 
Inspirados nessas palavras-chave, os autores sistematizam seis pontos fundamentais dentro de um projeto documentativo:

1. O quê? - documentar significa antes de tudo escolher porque não se pode observar tudo ao mesmo tempo e aquilo que não escolhemos também é uma escolha. A documentação não é uma descrição objetiva da realidade e sim resultado de escolhas que fazemos, por isso envolve escolha, seleção, assumir conscientemente um ponto de vista e transformá-lo em elemento narrativo.

2. Para quem? - a documentação é sobretudo um material público e pode destinar-se às próprias crianças, aos pais e familiares, ao grupo de trabalho, colegas e à comunidade escolar.

3. Com o quê? - os instrumentos para as documentações podem ser variados em forma e conteúdo, existe uma pluralidade de opções que deve responder às intenções de cada projeto documentativo. Há ainda a possibilidade de se exercitar na construção de um instrumento próprio para as documentações de acordo com o contexto educativo.

4. Como?-assumir uma forma documental está intimamente ligado ao que queremos comunicar, por isso refletir sobre a melhor forma de fazê-lo é fundamental. Para além da escrita, está bastante incorporada nas escolas infantis a representação iconográfica, contudo é relevante a discussão do espaço que as imagens tomam no fazer cotidiano, pois muitas vezes é ignorada sua potencialidade comunicativa tornando-se apenas ilustrações dos textos escritos. As imagens, gráficos e principalmente as fotografias constituem um grupo bastante rico a ser expressado e (re)conceitualizado no âmbito da educação.

5. Quando?- quando documentar e quanto tempo dedicar às documentações são perguntas que não possuem respostas definitivas e não pode ser mensurável, pois é muito relativo a cada contexto educativo e a cada projeto documentativo específico. Contudo é fundamental que a prática da documentação pedagógica não seja marginalizada nas escolas, há que se garantir tempo de trabalho para sua realização, tempo este praticado tanto 
individualmente por cada educador como também coletivamente entre a equipe educativa.

6. Onde? - os espaços destinados às documentações produzidas devem abranger dentro das possibilidades de cada contexto um espaço para a produção, espaço para mostrar o que se produziu e um espaço para arquivar e conservar a memória dos materiais.

Malavasi e Zoccatelli (2012) salientam, ainda, seis pontos de atenção em que o processo documentativo se organiza:

I - Observação - 1: projetar a observação / 2: observar / 3: recolher o material bruto

II - Análise e Seleção do Material Observado - 4: seleção do material compartilhando, o que se quer documentar e por quê.

III - Reelaboração, Tradução, Interpretação, Avaliação - 5: reelaboração, interpretação e aquisição de significados, tradução segundo o destinatário / 6: análise do projeto documentativo, avaliação e autoavaliação.

Nota-se que, nesse processo, a documentação pedagógica vai além da coleta de dados, apesar de depender deles e abrange uma série de possibilidades entre imagens, fotografias, escritas, reflexões do professor, desenhos, vídeos entre outros. A documentação pedagógica requer essencialmente a escuta das crianças e as ferramentas que utilizamos para ouvi-las são as mais variadas. Gandini e Goldhaber (2002) evidenciam que quanto mais recursos utilizamos, mais rica será nossa compreensão, contudo, cada ferramenta utilizada tem seus limites e potências, são de alguma forma tendenciosas, por isso combinar formas de coleta de dados, assim como confrontá-los com nossos parceiros ou mesmo com as crianças, pode ampliar a visão do processo.

Confrontar especialmente as documentações pedagógicas com as próprias crianças é uma dinâmica defendida por vários autores (AZEVEDO, 2009; AZEVEDO; SOUZA, 2010; GANDINI; GOLDHABER, 2002; HELM; BENEKE, 2005) como fundamental para criar o diálogo entre as culturas do adulto e da criança, atitude ética que considera a potência das crianças. Ao participarem adultos e crianças de um mesmo processo cria-se o diálogo entre a cultura da criança e a cultura do adulto. A cultura infantil ganha visibilidade e aumenta-se a 
capacidade de compreensão de suas culturas de pares. Sobre a visibilidade das crianças Rinaldi (2012) aponta que:

A documentação, portanto, é vista como a escuta visível, como a construção de traços (por meio de notas, slides, vídeos e assim por diante) que além de testemunhar os processos e trajetórias de aprendizado das crianças, também os tornam possíveis por serem visíveis. Para nós, isso significa tornar visíveis e, assim, possível as relações que são a base do conhecimento (p. 129).

Dahlberg, Moss e Pence (2003) concebem ainda a documentação pedagógica como um meio para a desconstrução de discursos dominantes. Na medida em que a documentação não é neutra e comunica (criança, pais, professores, equipe escolar e comunidade) ela é capaz de "transgredir o projeto grandioso da modernidade e sua determinação de mapear toda a vida humana na busca da Verdade, da Beleza e da Bondade" (p. 200).

A documentação pedagógica como possibilidade de ouvir as crianças, de renunciar o professor como mestre da verdade e da justiça está relacionada à dimensão ética, denominada por Dahlberg, Moss e Pence (2003) como a ética de um encontro. O papel da documentação pedagógica é uma proposta de transformação e nas palavras desses autores ela oferece:

[...] um ponto de partida importante para o diálogo, mas também para criar confiança e legitimidade em relação à comunidade mais ampla, abrindo e tornando visível o trabalho dessas instituições. Graças à documentação, cada criança, cada pedagogo e cada instituição podem conseguir uma voz pública e uma identidade visível. Isso que é documentado pode ser visto como uma narrativa das vidas das crianças, dos pedagogos e dos pais na instituição dedicada à primeira infância, uma narrativa que pode mostrar as contribuições das instituições para a nossa sociedade e para o desenvolvimento da nossa democracia. "A documentação pode oferecer às crianças e aos adultos momentos reais de democracia que teve sua origem no reconhecimento e na visualização da diferença provocada pelo diálogo. Esta é uma questão de valores e de ética" (RINALDI, 1994, p. 206).

Essa característica ética da documentação pedagógica também é abordada por Hoyuelos (2006), visto que pressupõe uma postura responsiva perante os outros que estão envolvidos. Especificamente sobre as crianças bem pequenas de creche há que ter especial cuidado para interlocução da cultura do adulto e da criança pelo fato de sua comunicação com o mundo não ser prioritariamente verbal, nesse sentido as documentações pedagógicas surgem como ponto de encontro entre as culturas e elemento estruturante:

A documentação em creche tem uma importância vital na criação do diálogo entre duas culturas - a cultura da criança e a cultura do adulto - e requer uma atitude ética e responsiva porque as crianças desta faixa etária não verbalizam, através da linguagem convencional (a fala), os seus pensamentos, percepções, gostos, sentimentos, preferências, tal como não verbalizam os sentidos e significados que atribuem às experiências. 
Precisam, portanto, de um adulto que as escute, que seja capaz de "ler" os seus sinais, de compreender as outras linguagens que a criança usa para participar, comunicar e narrar. Este é um esforço complexo porque sabemos que a formação das educadoras não as preparou para fazer esta escuta dos sinais das crianças. A documentação pedagógica é um instrumento estruturante e estruturador da prática porque permite estabelecer pontos de contacto entre estas culturas, analisar e reflectir, em companhia, os processos e as realizações das crianças e dos adultos, arquitectar experiências contínuas e interactivas (Dewey, 1971); (AZEVEDO; SOUZA, 2010, p. 3).

Dahlberg, Moss e Pence (2003) concebem a documentação pedagógica como um exercício da autonomia do professor e acreditam que é uma contribuição para o projeto democrático da instituição infantil na medida em que torna visível o trabalho pedagógico. Em instâncias maiores a documentação pedagógica tem papel fundamental na construção de significado sobre a infância e sobre nós mesmos já que “... nós co-construímos e coproduzimos a documentação como sujeitos participantes ativos" (p. 193).

\subsection{O aspecto comunicativo e os diferentes interlocutores da prática da documentação pedagógica}

A documentação pedagógica para além de um recurso à visibilidade, à reflexão e à projeção do trabalho com as crianças é também um veículo comunicativo. As documentações podem abrir as portas das instituições e estabelecer o diálogo entre aqueles que dela participam e aqueles que a visualizam. Malavasi e Zoccatelli (2012) aprofundam a questão do aspecto comunicativo das documentações ao dizerem que toda documentação é absolutamente pública e que tão importante quanto aquilo que ela comunica é também a relação que ela estabelece com o interlocutor que a recebe. Esta relação estabelecida pode ser uma nova interpretação e um novo olhar para enxergar o percurso exposto, o que Benzoni (2001) considera de uma postura diferenciada frente ao destinatário das documentações, tornando-se eles interlocutores ativos com potência dialógica.

As documentações podem assumir diversos formatos (cadernos, panfletos, painéis, livros, multimidiáticos), fazer uso de tantos recursos (escritos, imagéticos, áudios e vídeos) e a escolha para estes formatos depende dos objetivos dos educadores em relação aos interlocutores. Tomaselli e Zocchi (2009) e Malavasi e Zoccatelli (2012) enumeram os diversos interlocutores: 
1. Documentar para e com o grupo de trabalho, ou seja, colocar as documentações a serviço da prática reflexiva em parceria dos educadores, comunicando-lhes o percurso vivido e estabelecendo uma efetiva circulação das experiências com as crianças. Nesse caso não se entende os colegas de trabalho e a equipe educativa como receptores das informações apresentadas, mas como potentes figuras de estabelecimento de diálogo para que se possa reconceitualizar a prática.

2. Documentar para as crianças as ajudam a recordar as experiências e reviver as emoções fazendo com que o processo vivido torne-se mais significativo e consciente. É importante também oferecer as documentações às crianças para que elas possam ressignificar e interpretar à sua maneira o percurso apresentado, movimento importante para sua identidade em construção. Ao reviver suas pesquisas por meio das documentações as crianças podem se sentir partes um todo maior no qual são consideradas as subjetividades de cada um na construção do coletivo.

3. Documentar para as famílias a fim de que se integrem ao processo educacional de seus filhos e tornem-se também participantes das experiências.

4. Documentar para a comunidade significa favorecer a construção de uma imagem de infância potente, valorizar a cultura da infância, torná-la visível socialmente ao estabelecer o diálogo com todos aqueles que também se relacionam com ela, sejam psicólogos, médicos, cidadão, outros educadores, administradores públicos que cuidam da educação.

Malavasi e Zoccatelli (2012) salientam ainda três eixos comunicativos das documentações: I - declarar, informar, acolher; II - restituir, recontar, compartilhar; III interrogar-se, projetar, obter caminhos do processo. Rinaldi (2001, Apud Paige-Smith e Craft, 2010) ressalta o aspecto comunicativo e a relação dialógica:

Estou convencida [...] de que o efeito da documentação (documentos, notas, slides, gravações) não se limita a tornar visível o que é, mas que, ao contrário, por tornar uma experiência visível, a documentação permite que a experiência exista e assim a faça passível de compartilhamento e abertura aos "possíveis" (interpretações possíveis e diálogos múltiplos entre crianças e adultos)... (p. 40). 


\title{
4.3 Organizar o presente, projetar o futuro e conservar a memória: sobre os tempos da prática com documentação pedagógica
}

Hoyuelos (2006), ao citar Sergio Spaggiari, diz que é mais fácil um caracol deixar marcas de seu próprio caminho do que uma escola ou um professor deixar marcas escritas de seu trabalho. A prática da documentação pedagógica pode ser uma alternativa para esta realidade, contudo é importante ressaltar que a falta de tradição documental escolar resulta em um campo relativamente novo para a educação, com fundamentos ainda reduzidos (BASSOTTO, 2011). Por outro lado, o pouco tempo com que a expressão documentação pedagógica circula no campo educacional pode ser uma vantagem, como diz Barbosa (2012, p.1):

\begin{abstract}
A expressão documentação pedagógica parece ter potência para produzir outros sentidos. Embora ela já circule há algum tempo nos discursos pedagógicos, não ocupou, ao menos até a última década do século $\mathrm{XX}$, um lugar de destaque na literatura educacional do país. Talvez exatamente aí esteja sua potência. A prática da documentação pedagógica, ao tentar produzir outros sentidos, sacode as já cansadas e saturadas palavras da didática, como planejamento, currículo e avaliação, bem como sua estruturação linear: primeiro se definem objetivos, depois conteúdos, depois estratégias... Como se, ao escrever um plano, as definições posteriores não redefinissem as iniciais.
\end{abstract}

Por meio da documentação se constitui a história de uma instituição, é oferecida a identidade que faz referência a todos os envolvidos no processo (GANDINI e GOLDHABER, 2002). Ao criar memórias, a documentação oferece a oportunidade de ser novamente interpretada e refletida (DAHLBERG, MOSS e PENCE, 2003), ou seja, torna-se memória viva das instituições, que garante a presença das crianças mesmo quando não estão presentes (AZEVEDO, 2009). A memória não evoca somente o passado, mas estabelece uma relação entre a história vivida e as projeções futuras (MALAVASI; ZOCCATELLI, 2012), revela o processo de formação da identidade individual e do grupo com a qual é possível sustentar os passos futuros.

A identidade docente também é conservada como constantemente construída. Ao poder revisitar suas práticas os educadores refletem sobre sua profissionalidade e, nas palavras de Dolci (2011), se não narramos nossas histórias e não deixamos marcas não nos damos conta do que fazemos. 
O que foi colocado compreende a prática documentativa como recurso à memória no sentido da conservação da cultura da escola, mas igualmente uma memória dinâmica que instrumentaliza o pensar reflexivo do presente organizando o trabalho em andamento com vistas às novas perguntas que projetam o percurso futuro. Assim podemos dizer que as documentações oferecem suporte para os três tempos no sentido de organizar o presente, projetar o futuro e conservar a memória.

\subsection{O lugar da documentação pedagógica nas escolas de educação infantil: condições de trabalho e reconhecimento do desenvolvido}

Um aspecto importante e que merece destaque dentro da perspectiva documentativa refere-se às condições em que elas são possíveis de serem realizadas, condições essas que envolvem, sobretudo, o reconhecimento de sua importância para o trabalho educativo. Como bem colocam Dahlberg, Moss e Pence (2003), criar tempo para os processos reflexivos individualmente como em equipe não é prioritariamente uma questão de recursos, mas sim uma questão de priorizar espaços para a documentação pedagógica. Visualizar a prática requer um processo documentativo que esteja integrado ao trabalho cotidiano e que tenha sentido para os educadores. Não se trata de ser mais uma exigência institucional a ser seguida, é um trabalho de envolvimento de todo o contexto que não pode estar à margem do processo, representa o coração pulsante no interior das instituições (MALAVASI; ZOCCATELLI, 2012), é um trabalho regular e sistemático (BERGONZINI, 1998) que transita da autorreflexão para o diálogo entre pares e só é possível quando se garante tempo e espaço de trabalho.

Garantir tempo significa reconhecer a documentação pedagógica como prática de estudo e de aprofundamento que precisa de um tempo quantificado, legitimado e não clandestino. Um tempo, dessa forma, quantitativo organizado dentro de uma periodicidade, mas que também deve conter seu aspecto qualitativo (MALAVASI; ZOCCATELLI, 2012), ou seja, atribuir tempo para a realização das documentações não significa somente dispor horas de trabalho além daquelas em que os educadores estão diretamente com as crianças, mas também fazer escolhas conscientes de quais momentos esse tempos são qualitativamente mais produtivos. As documentações pedagógicas precisam de um tempo protagonista entre as 
atividades pedagógicas, praticar a documentação pedagógica significa incorporá-la ao cotidiano, atribuindo-lhe sua importância. Mensurar o tempo quantitativo é, contudo, um aspecto muito subjetivo que depende principalmente dos contextos particulares e das condições possíveis, mas na medida em que se legitima o trabalho com a documentação pedagógica é certo que o tempo destinado a ela será constantemente repensado.

Sobre o espaço, Bergonzini (1998) acredita que são precisos lugares especificamente destinados à documentação para que se possa refletir, acessar arquivos, dialogar em parceria. Ela fala do valor dos Centros de Documentação (espaços existentes na Itália próprios para arquivo, consulta e produção de documentações), mas em proporções menores é importante que se garanta o espaço de uma sala nas escolas onde todo o processo com documentação possa ser realizado. Malavasi e Zoccatelli (2012) ressaltam que a garantia do espaço não é apenas um lugar físico que acomode as documentações, mas também um ambiente mental capaz de colocar as ideias em reflexão e proporcionar inspirações para o pensamento. As autoras advertem ainda que a impossibilidade de documentar revela-se menos como falta de técnica do que falta de reconhecimento da importância documentativa. É claro que no exercício de documentar é preciso espaço, tempo, recursos, materiais, mas de nada eles adiantarão se a consciência formativa não estiver no centro das ações dos educadores.

Nas escolas infantis criar espaços e tempos para a prática documentativa ainda é um desafio, é certo que, especialmente na realidade brasileira, equacionar essas questões práticas não é fácil, porém, ao se criar uma cultura documentativa e reconhecer nela a potência para o desenvolvimento do trabalho com as crianças, dá-se o primeiro passo para isso.

\subsection{Da confecção de produtos à construção de processos}

Oliveira-Formosinho (2007), ao apresentar dois modos de fazer pedagogia, nos ajuda a compreender o papel das documentações pedagógicas. De um lado temos uma pedagogia transmissiva, na qual os professores diagnosticam, prescrevem tarefas e objetivos com vistas a avaliar os resultados. Do outro lado temos a pedagogia-em-participação que ao contrário da primeira não foca nos resultados, mas nos processos das crianças e se utiliza da documentação pedagógica para a atribuição de significado que está em constante reconstrução da experiência. 
O que a documentação pedagógica oferece é a interpretação dos processos ao invés da análise de resultados, contudo também é importante diferenciar quando os registros tornam-se documentações. Os registros realizados ao longo do processo podem vir a serem documentações pedagógicas, mas não se configuram como tal se lidos e interpretados somente no final das experiências (RINALDI, 2012). Este pequeno detalhe faz toda a diferença, não basta o prefixo "re" - releitura, revisitação, reconstrução da experiência, reinterpretação - para a prática com a documentação pedagógica se todas as ações não estabelecerem um diálogo ao longo do processo das experiências com as crianças. Se todos os registros não intervierem durante a trajetória de aprendizagem, dando sentido e direção ao processo, eles serão apenas documentos situados dentro de um campo espaço-temporal que garante a permanência de uma memória coletiva, mas que não foi em busca do processo de construção da aprendizagem das crianças. Davoli (2011) reafirma isso ao dizer que as documentações não são apenas memórias de algo construído, mas instrumentos que ajudam a entender como está sendo feito o que se faz.

A produção de materiais no âmbito escolar pode muitas vezes estar fixada à ideia de exposição, mostra, museu e não é questionável a qualidade com que esses materiais podem ser visualmente apresentados, mas o risco que se corre é desses produtos serem apenas fragmentos informativos que desconsideram os processos com as crianças e o contexto das experiências. É muito simples expor um produto como resultado de um percurso, por isso o salto de qualidade do produto ao processo envolve aumento da complexidade do trabalho docente adentrando a esfera subjetiva e interpretando continuamente os significados (COVRI, 2001).

Hoyuelos (2006) discute a questão dos produtos, mas sem esquecer o processo ao dizer que a documentação pedagógica contém um conteúdo e uma forma documental que permitem a reflexão rigorosa. Com isso ressalta que apesar de todos os pressupostos processuais, reflexivos e interpretativos que a documentação pedagógica exige ela é materializada em uma forma documental que, contudo, não pode ser reduzida a produto. Uma exposição, por exemplo, pode configurar-se como uma documentação da instituição se elaborada ao final das experiências a partir dos registros colhidos, mas também pode ser fruto de um intenso trabalho em documentação pedagógica que envolveu o planejamento flexível ao longo do processo e é estruturado em uma forma documental, no caso, uma exposição.

Ao falarmos de processo, dizemos do movimento constante da interpretação dos fatos e inevitavelmente das escolhas. Escolhas entre muitas outras que poderíamos fazer. Dahlberg, Moss e Pence (2003) referem-se à documentação pedagógica a partir de dois temas 
fundamentais: conteúdo e processo. O conteúdo é o material que registra as ações das crianças e pode ser feito de muitas formas: vídeos, áudio, fotografias, observações, trabalhos das crianças, entre outros. O conteúdo é o que torna visível o trabalho pedagógico. O processo envolve o uso desses materiais como instrumentos de reflexão do trabalho pedagógico e aqui cabe tudo que já foi discutido anteriormente sobre a prática reflexiva.

Toda documentação pedagógica não deixa de ser de alguma forma um registro, uma marca, uma memória, contudo, os registros não são documentações pedagógicas, requerem um debruçar-se sobre, uma reflexão para se constituírem como tal. Este aspecto peculiar é que a torna um processo de constante coconstrução, pois envolve os adultoseducadores, mas essencialmente as crianças e sua ação potente que as tornam coconstrutoras de suas próprias histórias e ressignificam a infância a partir de uma visão mais ampliada. Proporcionar às crianças as documentações pedagógicas que produzimos sobre elas e em parceria delas é crucial dentro do processo dessa prática pedagógica. As crianças podem e devem participar, interpretando a partir de seus pontos de vista e essa participação é diferente conforme a faixa etária.

\subsection{Os limites da documentação pedagógica: qualidade $x$ quantidade}

É sempre fundamental que o educador tenha consciência das escolhas que faz nos processos de documentações pedagógicas, pois os pedagogos tendo nas mãos as possibilidades de escolha correm o risco de transformar a prática da documentação pedagógica em controle de poder. Dahlberg, Moss e Pence (2003) ressaltam a importância da equipe de educadores se questionar sobre os caminhos que estão seguindo e se perguntarem constantemente sobre o direito que têm de interpretar os feitos das crianças dentro de uma postura ética.

No exercício da documentação pedagógica, o educador se confronta, a todo o momento, com escolhas que, ao serem feitas, descartam outras possibilidades igualmente legítimas e este panorama faz com que tenham que lidar com os limites que os atravessam em sua prática. As limitações também são encontradas quando se escolhe narrar processos individuais ou coletivos do grupo de crianças. 
Lidar com essas escolhas e limites requer esclarecer um grande equívoco no campo educacional que nem sempre é consciente e manifestado: não se documenta para mostrar que se trabalha muito, mesmo porque trabalhar muito não significa trabalhar bem e documentar não significa recontar em grandes quantidades, mas recontar de forma qualitativa (MALAVASI; ZOCCATELLI, 2012).

\subsection{Estética, escrita e imagens na documentação pedagógica}

Para Hoyuelos (2006) a documentação é entendida como uma narrativa de sedução estética, segundo a proposta de Loris Malaguzzi. Nesse sentido, estética trata-se da própria atuação prática da vida, das decisões da experiência, onde coexiste uma tensão vital que faz com que a experiência seja autêntica, comunicativa, crítica e transcendente. A estética é entendida como uma forma de vida a partir de uma vivência harmoniosa:

[...] a pedagogia de Loris é estética por sua capacidade de revelação, de desocultar o essencial com novas relações entre acontecimentos que parecem distantes, por sua tensão capaz de transgredir a si mesmo sem nunca trair-se, e também por sua aptidão de comunicação hieroglífica, metafórica e simbólica que multiplicam nossa imagem do mundo e da infância. Para Malaguzzi formamos parte de um mundo em que as distâncias estão se encurtando. Isto provoca que possamos ser habitantes de muitos mundos, com grande inter-relação entre as culturas, o que significa que nunca estamos sós. Nossas ideias e concepções nos acompanham sempre e contaminam nossas teorias, esperanças, palavras, pensamentos e emoções. Interagem conosco e ocasionam interdependências que nos levam a construirmos e reconstruirmos - como em um caleidoscópio constantemente em um mundo, ao mesmo tempo que esse mundo vem reelaborado por nosso próprio atuar nele. A concepção de Malaguzzi, neste sentido, é uma concepção de harmonia ecológica com o ambiente e com o cosmos (HOYUELOS, 2006, p. 239).

A documentação revela a experiência e a experiência é estética. Ao definir a estética no pensamento de Malaguzzi, Hoyuelos organiza a experiência estética em três princípios: 1) a escola como âmbito estético habitável; 2) construir pedagogia é sonhar a beleza do insólito; 3) educar supõe as capacidades narrativas de sedução estética. A documentação aparece como uma das estratégias do terceiro princípio.

Para além da ideia estética da documentação, que oferece uma imagem adequada e relacional da infância, a documentação é também ética na medida em que considera a 
educação e a escola transparentes, e é ainda política quando torna público o fazer escolar. O autor enfatiza que a documentação é o elo perdido entre teoria e prática e serve como um argumento para pensar melhor e pensar diversamente sobre a atuação educativa.

A dimensão estética deve ser entendida como essa capacidade relacional que coloca as subjetividades em interação proporcionadas pela documentação, esta segunda pele que revela a vida escolar (HOYUELOS, 2006). Estética não pode ser compreendida somente como o belo e ordenado, mas também como riqueza e complexidade da experiência. A documentação, dentro da perspectiva estética, proporciona cultivar nas crianças a sensibilidade de se encontrarem, pesquisarem e construírem tantas ideias de beleza (MALAVASI; ZOCCATELLI, 2012).

Em termos mais práticos, a documentação atravessada por este conceito de estética, proporciona a relação entre todos aqueles que dela fazem parte e constrói uma imagem de infância essencialmente a partir de narrativas de duas modalidades: a escrita e as imagens que assumem significados, força, funcionalidades individualmente e também juntas quando associadas oportunamente. A coerência entre palavras e imagens deve ser harmônica, fluida, complementar e essa coerência não é fácil de ser definida, depende da sensibilidade de cada um (MALAVASI; ZOCCATELLI, 2012).

Sobre a escrita, Malavasi e Zoccatelli (2012) falam do esforço necessário dos professores para se exercitarem na construção de textos, o que muitas vezes não é fácil, requer um tempo de silêncio e de pensamento. Não há regras específicas para se escrever. Nas documentações os textos se colocam até de certa forma poéticos, podem contar com falas das crianças e devem se tornar o que as autoras (citando Rinaldi, p. 56) denominam de escrita tridimensional, ou seja, aquela que não transmite simplesmente uma mensagem objetiva, mas a mensagem que se esforça em transmitir significados.

No que se refere às imagens, nos remetemos aos desenhos das crianças, gráficos e especialmente às fotografias que têm ganhado espaço cada vez maior na área educacional e alguns autores discorrem sobre o tema.

Hoyuelos (2006) comenta da obsessão de Malaguzzi pelos registros docentes que ganham maior possibilidade visual com o recurso da máquina fotográfica, que o fascina e passa a ocupar um papel importante dentro da pedagogia reggiana. A fotografia oferece uma nova competência aos educadores e Azevedo (2009) complementa dizendo que o segredo de como documentar para Malaguzzi reside na sensibilidade necessária que considera o valor da experiência, do atuar, do pensar, da investigação e do aprender das crianças. A documentação fotográfica pode desvelar através das caras, dos olhos, da boca, dos gestos, das posturas, os 
pequenos sinais que revelam as tensões, os esforços, o prazer, o desejo, os sentimentos e as expectativas das crianças (HOYUELOS, 2006).

Contudo, a fotografia é sempre subjetiva e manipulável, uma imagem do real que depende daquele que a produz. A fotografia não mostra a realidade, mas a ideia que se faz dela. Fotografar é um modo particular de comunicar, mas somente o uso consciente e pensado faz da máquina fotográfica um instrumento de cultura e Malavasi e Zoccatelli (2012) indicam o cuidado com o uso indiscriminado e exagerado das imagens no contexto da educação infantil.

Sobre a grande quantidade de imagens tiradas sem necessariamente se avaliar a qualidade com que são feitas recai o caráter imediatista que acentua a grande força das imagens, mas igualmente o seu grande perigo (FREUND, 2006). A potência de uma fotografia, devido seu amplo alcance e a facilidade de produzi-la, gera um ritmo desenfreado e pouco refletido sobre o universo imagético em que estamos inseridos. O excesso de imagens impede o olhar, a rapidez com que concebemos o modo de viver e a facilidade da produção de imagens nos instiga constantemente à produção excessiva sem qualquer controle. Sontag (2006) aponta que a vida contemporânea está organizada por meio de imagens que são indispensáveis para a saúde da economia, a estabilidade política e busca da felicidade privada, porém defende que a grande quantidade de imagens faz perder a realidade e aniquila a experiência. Segundo ela, é claro que a exposição imagética revela uma realidade, mas quando exposta excessivamente causa exatamente o efeito contrário, perdendo o realismo.

A proposta de Malaguzzi (HOYUELOS, 2006) é exatamente contrária a esta, ele entendia as imagens como um recurso a mais para ler e interpretar as crianças considerando suas potências, propunha a fotografia como outra linguagem de escuta e desconsiderar a fotografia como linguagem é ignorar os processos pelos quais ela foi concebida a partir do olhar daquele que fotografa, que elege valores éticos e estéticos que dependerá de um ethos, que Bourdieu (2004) defende como a classe social. O autor diz que existe um olhar que é de classe social que influenciará a produção e a interpretação das imagens. Tais comportamentos se organizam sistematicamente a partir de regras implícitas e explícitas características dos contextos vivenciais do fotógrafo ou do espectador, por isso é preciso compreender o contexto daquele que fotografa e daquele que aprecia a fotografia.

Na mesma linha, Kossoy (2002) defende diferentes leituras a partir de um repertório cultural particular e Freund (2006) enfatiza que a objetividade das imagens é mera ilusão visto que podem ser manipuladas de acordo com interesses distintos associadas às legendas, ou organizadas em conjuntos específicos para determinado fim, por exemplo. Ou seja, os autores 
concordam com a não neutralidade de quem produz a imagem e de quem a recebe e a interpreta. Essa riqueza de sentidos e significações compõe o campo repleto de ambiguidades do campo imagético, ressaltado por Kossoy (apud SILVA, 2008):

Isto é próprio da natureza da fotografia: ela nos mostra alguma coisa, porém seu significado a ultrapassa. Existe um conhecimento implícito nas fontes não verbais como a fotografia; descobrir os enigmas que guardam em seu silêncio é desvendar fatos que lhe são inerentes e que não se mostram, fatos de um passado desaparecido, nebuloso que tentamos imaginar, recriar, a partir de nossas imagens mentais [...]. Toda fotografia é o frontispício de um livro sem páginas, um elo que nos anuncia algo e que, ao mesmo tempo, nos despista. Resta-nos mergulharmos nesses fragmentos deslizantes de ambiguidades e evidência, para tentarmos desvendar os mistérios que se escondem sob olhares interessantes e paisagens perdidas (p. 26).

Produzir uma imagem envolve um campo de escolhas e nas escolhas lidamos diretamente com o poder, assim, as realidades podem ser condicionadas e o diálogo se faz imprescindível no sentido de problematizá-la. Utilizadas nas documentações pedagógicas, as imagens também refletem o campo de poder em que só a interpretação em parceria pode garantir a ética na interpretação e olhares distintos de uma mesma cena. Por isso devemos aprender a nos comunicar com as imagens:

... dialogarmos com elas, decifrarmos seus códigos e resgatarmos suas realidades interiores, seus silêncios, isto é, seus significados, o sentido da vida e das ideias escondido sob a aparência de suas realidades exteriores, iconográficas, a realidade das aparências, aquela que encantou a Narciso (KOSSOY, 2005, p. 6).

Sontag (2006) tem postura mais radical e questiona a insistência pela interpretação. Ao interpretarmos, estamos dominados a uma experiência restrita, contudo é impossível pensarmos os seres humanos como seres não carregados de interpretação, o que sugere que o problema não é a interpretação, mas o olhar único de interpretar que prevalece, domina e restringe. Há que se estabelecer diálogos interpretativos e ir além.

Kossoy fala da fotografia como materialização documental e da relação produto e processo na concepção e produção de uma imagem fotográfica. Da mesma forma as documentações pedagógicas revelam esta relação entre produto e processo.

Entre palavras e imagens e tantos outros recursos que as documentações podem ser apresentadas, o primordial é que se revelem os processos das crianças ao estabelecer o diálogo entre as linguagens expressivas: que seja narrativa, mas também poética, como coloca Rinaldi (2001, apud PAIGE-SMITH; CRAFT, 2010, p. 40): 
Portanto, acredito que narrar o processo de aprendizagem requer o uso de linguagens verbais e visuais, não apenas de uma maneira narrativa analítica, mas também poética, metafórica, musical, física e dramática.

Em outras palavras, a fim de tornar uma experiência de aprendizagem possível - e, portanto, torná-la uma forma consciente de aprendizagem que pode também ser narrada -, os processos e a linguagem devem estar intimamente entrelaçados, de maneira a sustentarem-se reciprocamente e a sustentarem a própria qualidade da experiência de aprendizagem. O que nós de fato temos de documentar (e, portanto, trazer à existência) é o sentido "emocionalmente comovente" da busca pelos significados da vida que as crianças e os adultos levam em conjunto - um senso poético que as linguagens metafórica, analógica e poética podem produzir e assim expressar em sua completude holística.

Uma documentação pedagógica é fruto de observações dos professores apoiadas em registros coletados que podem ter as mais variadas formas: escritas, falas, desenhos, produções infantis e principalmente fotografias. Estas últimas são mais utilizadas pelo seu apelo imagético, por sua fácil coleta e por abranger todas as faixas etárias. Na prática com bebês é quase que exclusivo o uso das fotografias pelo fato de as crianças nessa fase ainda não produzirem desenhos, grafias e também por não falarem convencionalmente. Assim, é imprescindível discutirmos o uso das fotografias nas documentações pedagógicas com bebês, pensando em problematizar como as imagens são compreendidas e apropriadas pelos educadores da infância. 


\title{
5. POR UMA PEDAgOGIA PARA OS BEBÊS
}

\begin{abstract}
Deleuze se perguntava insistentemente, com Spinoza, o que pode um corpo (...) talvez nunca possamos sabê-lo, e a pretensão de antecipá-lo contribua, infelizmente, para obstruir parte dessa potência. Algo dessa ordem podemos também perguntar a respeito da infância e sua educação: "o que pode uma criança?". Não o sabemos. Quem sabe a pergunta não seja tão diferente da que interroga o que pode um corpo. Não estamos certos. Mas nesse espaço que a insistência da pergunta abre - e que nenhuma resposta consegue fechar - talvez encontremos força para desdobrar potências impensadas na infância. E um novo início para a educação.
\end{abstract}

Kohan, 2007

Apesar dos esforços para o reconhecimento da potência infantil muito ainda há que se percorrer, especialmente quando se refere à primeiríssima infância, entre zero e três anos. Pensar em um novo início para a educação, como propõe Kohan (2007), convida o campo a considerar também com maior atenção as potencialidades dos bebês.

Abordar o tema da educação de crianças entre zero e três anos implica atentar à trajetória histórica do atendimento dessa faixa etária ao longo dos tempos, trazendo ao foco questões concernentes ao pensar e fazer pedagógico no trabalho com bebês e crianças muito pequenas, tendo em conta uma compreensão desses sujeitos sócio-históricos ativos e competentes, e à formação de profissionais desse campo, considerando-os coconstrutores de suas identidades docentes.

\subsection{Os caminhos da educação em creches}

O reconhecimento da infância e de suas especificidades constituiu-se nas sociedades modernas a partir do que Ariès (2006) chamou de sentimento de infância. Separar as crianças da vida dos adultos, agrupá-las em espaços específicos e compreendê-las de forma distinta foram ações construídas e modificadas ao longo dos tempos. O sentimento de infância acompanha o movimento do sentimento de família, pois as famílias passam a ser organizadas em torno da criança, alterando a configuração das redes amplas de sociabilidade que envolvia 
outras relações para além dos pais com os quais as crianças estabeleciam trocas afetivas e aprendizagens (ARIÈS, 2006). Velhos, vizinhos, amigos, amas, criados, mulheres e homens diluíam a importância da família e do mundo privado e a partir do século XVIII a organização da família em torno da criança substitui a antiga sociabilidade mais ampla.

No contexto brasileiro, diante da responsabilidade das famílias pelas crianças e a nova configuração econômica que coloca cada vez mais pessoas no mercado de trabalho, a história das instituições dedicadas à infância acompanha essa nova configuração social no sentido de ampliar a rede de cuidados das crianças para além das famílias. As instituições que surgem para dar conta desse compromisso se sustentam no atendimento da mesma faixa etária em que a família ocupa lugar privilegiado, o que traz questões de compreensão de papéis no que tange ao cuidado e à educação dos pequenos (HADDAD, 1991, 2005).

As crianças que não encontravam o zelo fundamental no interior de suas famílias poderiam ser compensadas nas instituições que se destinavam a elas, nas quais a ideia era de proteção e assistência às vítimas da orfandade, do abandono e dos maus tratos; filhos da escravidão, de uniões ilegítimas e de lares desajustados (PINAZZA, 1997).

Fruto de uma sociedade que passa a se organizar em classes sociais, as instituições surgem para suprir a carência das crianças menos favorecidas. Os mais antigos lugares de amparo à criança pequena são os orfanatos datados da época da colonização. Na primeira metade do século XIX, criam-se as rodas de expostos junto às Santas Casas de Misericórdia que recolhiam bebês recém-nascidos e com o passar do tempo surgem os asilos infantis identificados por três tipos: asilos para órfãos, asilos para crianças expostas e asilos para crianças abandonadas ou delinquentes. Além dos asilos coexistem as creches e as escolas maternais e todas as instituições dedicadas à primeira infância revelam dois traços comuns: o caráter essencialmente assistencialista e a presença marcante de iniciativas privadas, tendo o poder público tímidos investimentos (KISHIMOTO, 1986; PINAZZA, 1997).

As creches surgem no início do século XX no Brasil e até este período não se distinguiam do atendimento em asilos e internatos priorizando o caráter assistencialista (KISHIMOTO, 1986). A creche visava suprir as carências da família, especialmente as mais pobres que contavam com as instituições para deixar seus filhos pequenos. Por serem destinadas às famílias carentes, visto que famílias ricas contavam com outras naturezas de cuidados no âmbito da vida privada, as creches firmaram-se pelo estigma de assistencialista e pela baixa qualidade dos serviços, tinham um caráter emergencial, de um mal necessário ao capitalismo que se apoiava na ideia de falta de cuidado da família e aos modelos de maternidade propostos pelas diferentes áreas (medicina, serviço social e psicologia) que 
prescreviam as ações a serem realizadas (PINAZZA, 1997; HADDAD, 1991; OLIVEIRA, ET AL., 2011; ORTIZ; CARVALHO, 2012).

Na década de 1920, com a estruturação do capitalismo e a crescente urbanização, a defesa por creches nas classes operárias amplia-se, fruto da luta das mulheres por instituições dedicadas ao atendimento de seus filhos na medida em que ingressavam no mercado de trabalho. De outro lado, a nova configuração das famílias, agora nucleares e com pouco acesso aos familiares como tios e avós que ajudavam no cuidados dos filhos também contribui para a defesa das creches (CARVALHO; PEDROSA; ROSSETI-FERREIRA, 2012).

Entre as décadas de 1930, 1940 e 1950 poucas creches encontravam-se fora das indústrias e as que existiam pertenciam às entidades filantrópicas, que contavam com donativos das famílias mais abastadas, recebiam ajuda governamental e eram defendidas por médicos e sanitaristas por meio do discurso assistencial-custodial, visando a alimentação, a higiene e a integridade física dos mais pobres (OLIVEIRA et al., 2011).

$\mathrm{Na}$ segunda metade do século XX observa-se um novo aumento das mulheres no mercado de trabalho. A partir de 1950 as mulheres da classe média passam também a ocupar um espaço no capitalismo e a redução dos espaços de brincar das crianças, fruto da urbanização acelerada, culmina no aumento da demanda pelo serviço de creches.

Na década de 1960, a visão meramente higienista é superada e a creche ganha a dimensão de acelerar o desenvolvimento infantil e compensar a privação cultural que as crianças pobres sofriam. Ao buscar na pedagogia novas referências, por não haver um campo específico voltado à primeira infância, as creches importam a ideia de preparação para a alfabetização, que culmina com as atividades pedagógicas e de coordenação motora. $\mathrm{Na}$ década de 1970 o discurso da creche como educação compensatória se fortalece, porém é importante pontuar que as pré-escolas particulares tornam-se cada vez mais numerosas, justificando seu trabalho no âmbito da criatividade, sociabilidade e desenvolvimento. Enquanto crianças pobres eram atendidas nas creches com propostas que partiam de uma ideia de carência, as crianças mais ricas eram colocadas nas pré-escolas vistas como ambientes estimuladores (OLIVEIRA, et al., 2011).

Ainda na década de 1970, o período de maior abertura política pressiona o poder público em busca de mais creches, associado aos movimentos feministas da época. A pressão pelas creches como um direito do trabalhador pressiona o Poder Público que incentiva outras iniciativas de atendimento às crianças como os lares vicinais ou creches domiciliares.

Como resultado das negociações trabalhistas, na década de 1980, aumenta o número de creches mantidas por empresas industriais, comerciais e por órgãos públicos. As creches 
lideradas pelo Poder Público sofrem considerável expansão, subordinadas às Secretarias do Bem-Estar Social. Algumas empresas concedem verbas para seus funcionários pagarem creches particulares aumentando o número de berçários e creches mantidos pela esfera particular para as crianças de classe média, chamadas por outro nome: escolinha. O atendimento nas chamadas "escolinhas" propunha o desenvolvimento cognitivo, emocional e social dentro de uma perspectiva da educação formal (OLIVEIRA et al., 2011).

A grande conquista das crianças pequenas e de suas famílias passa a ser assegurada no texto da Constituição Federal de 1988, que reconhece as funções sociais da creche como instituição educativa, direito de toda criança e dever do Estado. Esse documento inclui as creches ao lado da pré-escola e introduz uma importante mudança, visto que, em suas origens, constituíram-se em perspectivas distintas, como instituições diferentes (KISHIMOTO, 1986; PINAZZA, 1997). Kishimoto (1986) mostra que os primeiros jardins de infância eram voltados às famílias mais abastadas, já as iniciativas dirigidas às crianças das classes trabalhadoras possuíam cunho assistencialista.

Mais adiante, na década de 1990, com a consolidação da educação infantil como primeira etapa da Educação Básica garantida na Lei de Diretrizes e Bases da Educação Nacional No. 9394/96, as creches deslocam-se das áreas de assistência e de bem-estar social para a área da educação, passagem que vem acontecendo por caminhos tortuosos e de modo variado nos diferentes municípios e regiões brasileiros, o que requer um olhar atento daqueles que pensam e delineiam políticas públicas destinadas à educação infantil no território nacional.

O principal aspecto a ser problematizado refere-se à função social da creche, a qual não se tem clareza. Haddad (2005) chama a atenção de que o ganho legal da inserção da creche na esfera educacional não pode significar a renúncia dos contextos de cuidado que a criança pequena necessita, o que historicamente aconteceu. $\mathrm{O}$ contexto macrossocial do qual as crianças fazem parte envolve a intersecção entre a esfera privada da família e os assuntos de ordem pública, estes devendo compartilhar o cuidado e a socialização das crianças:

[...] romper polaridades tradicionalmente marcadas pela alternância entre o cuidado custodial e o enfoque escolarizante, pela ênfase ora dos direitos da família, ora dos direitos da criança e que acabam provocando cisões entre cuidar e educar, corpo e mente, família e instituição, acentuando a separação entre o ambiente educacional e a vida fora (HADDAD, 2002, p. 94).

O processo histórico brasileiro revela a evidente necessidade de creches e, atualmente, os espaços dedicados às crianças pequenas compartilham com as famílias o acolhimento dos novos integrantes da sociedade (BARBOSA, 2010). Ao deixar de identificar- 
se pelo cunho exclusivamente assistencialista, passando a ser pensada no âmbito da educação, a creche sofre ganhos consideráveis e a construção de outro olhar para a infância vem sendo construído historicamente no enfrentamento de posturas fragmentares entre o cuidar e o educar. Um dos ganhos mais relevantes sobre o contexto da educação das crianças pequenas refere-se à conquista das crianças como sujeitos de sua própria história, (re)criadora da trajetória cultural e não somente um indivíduo em desenvolvimento para tornar-se um indivíduo no futuro (PINAZZA, 2004).

No que tange aos discursos pedagógicos que enfatizam essa visão de criança, destacam-se: "Critérios para um Atendimento em Creche que Respeite os Direitos Fundamentais das Crianças" (CAMPOS; ROSEMBERG, 2009) originalmente publicado em 1995; as Diretrizes Curriculares Nacionais para a Educação Infantil (2009), originalmente publicada em 1998 e o Referencial Curricular Nacional para a Educação Infantil, também de 1998.

Atualmente, a creche passa a ser encarada como lugar de interação, aprendizagem e desenvolvimento tão bons quanto a família, embora se diferencie dela (CARVALHO; PEDROSA; ROSSETI-FERREIRA, 2012). No Brasil, se as vagas na creche antes atendiam um direito das mães, o discurso pelos direitos ampliou-se desembocando na discussão do acesso à creche como direito da criança. Sobre a condição dos direitos das crianças, Barbosa e Richter (2011) dizem:

Há, portanto, uma história dos direitos das crianças, que é fruto de uma conjunção de sentimentos e ideias que emergem de distintos campos da prática social e dos conhecimentos científicos. Direitos que são sempre decorrentes de disputas e negociações entre diferentes discursos. A constituição de olhares específicos sobre a infância, suas necessidades de proteção, igualdade, liberdade e participação são narrativas do reconhecimento de que as crianças, desde bem pequenas, exigem respeito e que são seres humanos também com direitos como os adultos (p. 7).

Ainda que o discurso dos direitos das crianças e das famílias sustente a efetivação das creches, a falta de vagas ainda é um desafio a ser vencido já que dados de 2011 apontam que apenas $18 \%$ das crianças brasileiras frequentam a creche (ORTIZ; CARVALHO, 2012).

Para além da falta de vagas que ainda é uma realidade, a oferta tem aumentado ainda que timidamente e Barbosa (2010) ressalta a distância existente entre a oferta de vagas, o discurso e a efetivação de uma pedagogia específica para as crianças pequenas, em especial, para os bebês:

Se nos últimos anos as vagas foram quantitativamente ampliadas, ainda não é possível afirmar que uma pedagogia específica para as crianças tenha sido efetivada. Em grande parte das instituições, as singularidades das crianças de 
0 a 3 anos, especialmente os bebês, ficaram subsumidas às compreensões sobre o desenvolvimento e a educação das crianças mais velhas. Afinal, até hoje as legislações, os documentos, as propostas pedagógicas e a bibliografia educacional privilegiaram a educação das crianças maiores. Assim, ainda que os bebês e as crianças bem pequenas estejam presentes na educação infantil, as propostas político-pedagógicas ainda mantêm invisíveis as suas particularidades e não têm dado atenção às especificidades da ação pedagógica para essa faixa etária (p. 1).

Equacionar a relação entre a oferta de vagas como direito das crianças e das famílias e a qualidade do atendimento em creches é urgente. A questão da qualidade esbarra nas práticas desenvolvidas, por isso é preciso discussão em torno do currículo para as crianças bem pequenas.

\subsection{Qual currículo para os bebês?}

É fundamental que se pense quem são os bebês (quais suas especificidades, suas formas de se relacionar com o mundo, necessidades e direitos) para que seja possível explicitar uma pedagogia compatível que assegure boa qualidade de experiências às crianças muito pequenas.

No que tange aos elementos norteadores de uma proposta educativa para bebês e crianças pequenas, as Diretrizes Curriculares Nacionais para a Educação Infantil (BRASIL, 2010), apontam um caminho para o currículo da educação infantil centrado nos eixos das interações e da brincadeira e considera que:

A proposta pedagógica das instituições de Educação Infantil deve ter como objetivo garantir à criança acesso a processos de apropriação, renovação e articulação de conhecimentos e aprendizagens de diferentes linguagens, assim como o direito à proteção, à saúde, à liberdade, à confiança, ao respeito, à dignidade, à brincadeira, à convivência e à interação com outras crianças (p.18).

Apesar dessa abordagem ampla que envolve toda a faixa entre zero e seis anos, o próprio documento reconhece a necessidade de uma orientação mais específica para os bebês e prevê a construção de um documento para a ação pedagógica com bebês, em fase de elaboração.

Ao se falar de um currículo para as crianças de 0 a 3 anos não se pode dissociar o cuidar do educar, segundo Kuhlmann (apud GUIMARÃES, 2011) na medida em que as creches buscam sua legitimidade no campo educacional cria-se uma falsa oposição entre ser 
educativa e ser assistencial. Os cuidados, muitas vezes, são vistos como algo negativo, em parte devido ao fato de as creches estarem vinculadas, historicamente, ao atendimento de crianças oriundas de classes menos favorecidas e sustentadas em discursos higienistas de médicos.

O Referencial Curricular Nacional para a Educação Infantil (BRASIL, 1998) também aponta o cuidar como eixo do currículo para as crianças pequenas que compõe o item Educar deste documento ao lado do brincar e da aprendizagem em situações orientadas.

A necessidade de cuidados especiais aos bebês é um fato indiscutível. Ignorar essa condição é desconsiderar uma de suas especificidades que, além da atenção e do acolhimento que garantam o seu bem estar, inclui a compreensão de suas capacidades e formas de se relacionar com o mundo:

A tarefa dessa pedagogia da pequeníssima infância é articular dois campos teóricos: o do cuidado e o da educação, assegurando que cada ato pedagógico, cada palavra proferida tenha significado, tanto no contexto do cuidado - como ato de atenção àquilo que temos de humano e singular como de educação, processo de inserção dos seres humanos, de forma crítica, no mundo já existente (BARBOSA, 2010, p. 6).

Pensar em um currículo para os bebês significa abarcar essas duas frentes e é evidente que tentar adequar atividades pensadas para crianças mais velhas aos bebês está em desacordo, além de ser desrespeitoso. Ainda que possam coexistir diferentes modelos de creches, mais ou menos compatíveis com as concepções dos usuários não se pode dizer que qualquer modelo de creche é satisfatório ou conveniente, pois a creche deve ser (ainda que existam maneiras diferentes de ser) um:

[...] ambiente seguro, com espaços estruturados de forma a propiciar a interação de crianças e a brincadeira, com equipamentos e materiais que enriqueçam essas experiências de interação, e principalmente com reconhecimento e respeito pelas competências e motivações e necessidades características de cada fase (além, é claro, de atender adequadamente à necessidades de alimentação, higiene, ritmos de atividade e repouso da criança) (CARVALHO; PEDROSA; ROSSETI-FERREIRA, 2012, p. 243).

Barbosa (2010), ao defender um currículo específico para os bebês, ressalta o ambiente da creche como locus de ampliação das relações dos bebês com o mundo, o que significa desenvolver um trabalho não apenas com atividades dirigidas, mas que garanta, sobretudo, a imersão em experiências significativas. Isso se faz com a criação de uma vida cotidiana a partir de práticas sociais que possibilitem alargar horizontes para que os bebês experienciem os seus saberes a partir das brincadeiras e da relação com o outro e com os objetos. 
Essa perspectiva de atuação com os bebês prevê um amplo rol de experiências nas mais diversificadas linguagens que se estabelecem em contextos de relações que, muitas vezes, são sutis, indiretas e discretas, mas nem por isso, frágeis ou impotentes. O ambiente é um dos campos de atuação com os bebês que tem essa intervenção silenciosa, mas que influi significativamente ao abarcar questões de espaço, relações e tempo.

Um espaço adequado, limpo, organizado, que garanta a segurança e também uma vasta possibilidade de experiências deve ser almejado, bem como devem ser proporcionadas relações significativas entre as crianças e os objetos oferecidos, oportunizando as relações entre elas, mediadas pelas suas relações com os adultos.

$\mathrm{Na}$ relação diária com os bebês, o educador precisa constantemente perceber a potência de suas ações na construção dos vínculos e no estabelecimento das relações ao dar colo e mamadeira, cuidar da higiene, oferecer objetos para sugar, chupar ou morder, auxiliar a viver em grupo, conversar, valorizar a construção da autonomia, valorizar os elementos de inserção cultural e também valorizar a família como ela é, considerando-a parceira na educação da criança (ORTIZ; CARVALHO, 2012).

Além do espaço e das relações, o tempo é também um aspecto de muita relevância quando se pensa o currículo para os bebês. Uma discussão mais ampla em torno da instituição escolar em geral, e não apenas da educação infantil, pode enriquecer o tema sobre o tempo.

Tiramonti (2005) fala da crise da escola e de uma nova equação entre espaço e tempo escolares. O processo de globalização rompe uma ordem estabelecida até então, o estado perde centralidade e tem-se um novo tipo de organização societária. Assim como a sociedade industrial cria um sistema de referências desconsiderando os contextos locais e buscando uma universalização, a sociedade pós-industrial provoca essa perda de referências. Segundo a autora, alguns estudiosos defendem que, nessa nova época, as instituições perdem a capacidade de marcar as subjetividades, caracterizando-se um período de desinstitucionalização.

A lógica escolar é colocada em xeque. A visão de uma instituição pensada na intersecção do passado, presente e futuro, ou seja, o passado configurado e transmitido pela instituição para construir uma representação compreensível de presente justificando a pretensão do futuro não se adequa mais. O que não está mais de acordo é a perspectiva do presente ser valorizado pela sua capacidade de transmitir uma versão do passado socialmente aceita e conter uma promessa de futuro a ser alcançada. Essa lógica também é questionada pelo fato de não ser mais somente através da escola o acesso à informação. A midiatização proporciona às pessoas o contato com esse acervo informativo e cultural de outras maneiras 
(através da televisão ou internet, por exemplo) e essas novas fontes de acesso nem sempre correspondem à sequência lógica temporal que a escola tinha como ideia entre passado, presente e futuro (TIRAMONTI, 2005). É questionada a condição de transmissão da escola e isso recoloca o professor não mais como um transmissor de conhecimento e sim como um facilitador ou guia de aprendizagem.

Bruner (1997) traz uma interessante contribuição dessa mesma ordem ao compreender a escola não como lugar de transmissão de conhecimento, mas como foro de cultura. A cultura, por sua vez, não está no lugar de ser transmitida e recebida segundo as relações dos professores (aqueles que sabem mais) para os alunos (aqueles que sabem menos), mas ocupa um lugar na escola de ser reconstruída e interpretada. A educação é lugar de cultura, mas uma cultura constantemente refletida em parceria e que tem suas bases na linguagem, pois esta não apenas transmite, mas cria ou constitui conhecimento ou realidade.

Esta nova perspectiva da escola como lugar de cultura que tem no professor um mediador da aprendizagem é constantemente afetada pela nova percepção de tempo que vivemos atualmente. A pressa e o imediatismo são tão fortes, bem como a calma e a espera são interpretadas como perda de tempo, que seria inocência achar que essa visão não afeta a escola infantil.

Ao falar especificamente dos tempos da infância, Hoyuelos (2008b) questiona os tempos escolares e a falta de tempo para as crianças. Ao recorrer ao pensamento grego fala das três definições sobre tempo: Aion (que é o sempre, a duração sem limites), Chronos (o tempo mensurável, objetivo, fragmentado e manipulável) e Kairos (tempo de alma, da experiência interior, subjetivo). Kairos é, sobretudo, a forma individual de cada um viver um tempo aparentemente igual, mas a obsessão pela medição do tempo nos cerca, nos invade e influencia decisivamente nossas vidas. Curiosamente, diz o autor, essa obsessão por controlar o tempo é um invento moderno, assim como a infância, e a escola se organiza de tal modo que mensura suas ações e se organiza para sempre alcançar objetivos.

Nesse movimento, todos devem ser iguais ao mesmo tempo e Hoyuelos (2008b) sugere a necessidade de quebrar essa relação, especialmente com os bebês:

As criaturas - sobretudo os bebês - não se movem pela medida do relógio. Seu tempo é o da ocasião, o da oportunidade dos instantes que o próprio crescimento proporciona em seu fluir, fluxo e trajetos vitais (p. 9, tradução nossa).

Assim, convida-nos a viver o tempo da infância e deixar-nos surpreender pelos feitos das crianças e interpretá-los como forma de compreendermos melhor a nós mesmos na 
medida em que recordamos as emoções aparentemente esquecidas de quando nós éramos crianças.

As crianças têm direito ao seu tempo e exigem de nós esse direito de serem esperados, coloca os educadores em um novo lugar de aguardar sem antecipações desnecessárias entendendo o sentido de aguardar como a espera com esperança (HOYUELOS, 2008b). Para o autor é preciso que a escola infantil encontre uma congruência entre os tempos individuais e os tempos sociais, o que é sempre um desafio devido à realidade atual que vivemos sob a cultura da pressa e do imediatismo.

Os movimentos que se destacam pela qualidade em instituições infantis também questionam entre outros aspectos a relação que nós adultos apresentamos às crianças com o tempo. Experiências de boa qualidade questionam essa relação e reorganizam suas atuações visando um tempo qualitativo, menos quantitativo e que, acima de tudo, pense na vivência dos tempos da criança.

Quando essas crianças são muito pequenas, há uma especificidade ainda maior na medida em que eles precisam de tempo para brincar, para se envolver em experiências significativas. Barbosa (2010) ressalta que é comum a difusão da ideia de que os bebês não se concentram por um longo período, contudo, o que falta é o olhar qualitativo para a relação deles com o meio e entre eles na direção de compreender os seus tempos e a potência que eles abrangem. Saber interpretar os tempos dos bebês é importante enquanto especificidade da faixa etária, mas igualmente importante é saber reconhecer o tempo particular de cada bebê em cada contexto específico de creche:

Um dos objetivos centrais da temporalização da vida das crianças está relacionado à estruturação do tempo coletivo, mas deve-se fazer isso sem deixar de respeitar os tempos pessoais (BARBOSA, 2006, p. 151).

A equação entre tempo e espaço é definida pelas rotinas na educação infantil, e para a faixa de zero a três anos as atividades de cuidado são compostas com momentos de jogos e brincadeiras. É primordial constituir essas rotinas dentro de estruturas mais flexíveis que saiam do tempo da ordem, da organização estática e burocrática para um planejamento móvel do tempo (BARBOSA, 2006).

É necessária ainda muita reflexão sobre o currículo e como encaminhar em termos mais práticos o trabalho do dia-a-dia. Barbosa (2006) elenca algumas ações primordiais que envolvem um percurso baseado na observação, planejamento, ações e experiências, acompanhamento e avaliação. Ressaltam-se ao longo desse caminho dois eixos principais que 
permeiam a atuação docente: a escuta qualificada e o acompanhamento processual, que serão abordados ao longo deste capítulo.

\subsection{Profissionalidade docente em creches}

Garantir um ambiente (tempos, espaço e relações) adequado aos bebês só é possível quando a equipe educativa está ciente da qualidade necessária para essa faixa etária, o que pode ser um grande problema dada a formação ser ainda um aspecto sensível em nosso país.

Pinazza (2004) enfatiza que o momento histórico atual passa pela determinação das especificidades da educação infantil, sendo a formação de seus profissionais uma das questões centrais do campo reflexivo dessa etapa da educação. A autora afirma que são inegáveis os avanços conseguidos pela infância e pela educação infantil deste o final da década de 1980 no âmbito institucional, porém são inúmeros os desafios que se impõem para que as conquistas legais ultrapassem os limites do papel e tornem-se realidades.

Pinazza e Neira (2012), ao falarem da questão da qualidade na educação infantil, reportam-se a documentos como os "Parâmetros nacionais de Qualidade para a Educação Infantil" (BRASIL, 2006), que consagra as teses de especialistas do campo e os "Critérios de Atendimento em creches que respeitem os direitos fundamentais das crianças", que anuncia questões relativas à qualidade. Os autores evidenciam o consenso em esfera nacional e internacional sobre a relação estreita entre a qualidade da educação infantil e a formação específica dos profissionais que atuam na área; e evocam os Indicadores da Qualidade para a Educação Infantil para sublinhar que:

Um dos fatores que mais influem na qualidade da educação é a qualificação dos profissionais que trabalham com as crianças. Professoras bem formadas, com salários dignos, que contam com o apoio da direção, da coordenação pedagógica e dos demais profissionais - trabalhando em equipe, refletindo e procurando aprimorar constantemente suas práticas - são fundamentais na construção de instituições de educação infantil de qualidade (BRASIL, 2009, p. 54).

Contudo não tem sido fácil dar conta da formação desses profissionais, seja inicial ou continuada e, conforme mostram as pesquisas recentes, a cisão entre os mundos da formação e do trabalho representa um grande problema na docência para a educação infantil (PINAZZA; NEIRA, 2012). 
A disposição da LDBEN nº 9394/96 que exige o curso superior para profissionais de educação infantil é uma grande conquista que beneficia as crianças, os educadores e o País, que aumenta seu nível cultural e social (ORTIZ; CARVALHO, 2012), mas há que se problematizar a qualidade dos cursos que os profissionais estão cursando.

O primeiro aspecto refere-se ao acesso aos cursos de formação inicial. Na esfera pública a falta de vagas nas universidades é uma realidade no Brasil, bem como o acesso a universidades particulares se restringe às possibilidades financeiras dos profissionais da educação, em geral baixa.

Outro agravante é que nos cursos de formação inicial para o exercício na educação da infância há uma pálida relação entre teoria e prática (PINAZZA; NEIRA, 2012), além de que, em sua maioria, não atenderem as especificidades da faixa entre zero e três anos, conforme apontam Pinazza (2004), Ortiz e Carvalho (2012), Pinazza e Neira (2012).

Por sua vez, a formação continuada historicamente é marcada pela ocorrência episódica que pretende oferecer trabalhos prescritos e práticas reprodutivas, além de enfatizarem a distância entre teorias abordadas e práticas vivenciadas (PINAZZA, 2004; PINAZZA; NEIRA, 2012). Segundo Pinazza e Neira (2012), a formação continuada:

Não pode se restringir às competências técnicas, porque devem operar em duas importantes dimensões que se encontram no âmbito da prática profissional traduzidas em culturas docentes: as particularidades de cada pessoa que exerce a profissão e as referências de práticas instituídas que compartilham com seus pares nas situações de trabalho (p. 15).

Os autores apontam ainda que há uma estreita relação entre formação, trabalho e identidade profissional e a interposição entre elas acontece por meio da prática reflexiva. A postura contra o primado da teoria e da técnica que está longe das práticas pauta-se no exercício crítico-reflexivo que conduz à autonomia e à auto-formação participada dos profissionais de educação (PINAZZA, 2004).

Carvalho, Pedrosa e Rosseti-Ferreira (2012) consideram relevante a formação continuada também dentro das próprias instituições para que se construa no coletivo uma concepção de educação que valorize as crianças e os bebês verdadeiramente. Ortiz e Carvalho (2012) citam que apesar da LDB também garantir formação em serviço oferecida pelas próprias Secretarias Municipais de Educação, estas padecem do mesmo problema da formação inicial de professores: falta de qualificação e aporte substancial para reflexão sobre as práticas.

Pinazza (2004) diz que, ao tratarmos da docência do profissional da educação infantil e dos programas de formação destinados a eles, há que se considerarem duas perspectivas de 
análise: as questões relativas a um contexto mais amplo da prática docente em geral e outra que considere as especificidades do trabalho com crianças entre zero e seis anos, o que dá sentido a um conceito particular de profissionalidade de professores de educação infantil, definida por Oliveira-Formosinho (2002) como:

[... ] ação profissional integrada que a pessoa da educadora desenvolve junto às crianças e famílias com base nos seus conhecimentos, competências e sentimentos, assumindo a dimensão moral da profissão (p. 43).

A mesma autora aponta que as especificidades da profissionalidade docente dos educadores de infância derivam:

1. Das características da criança pequena: a globalidade da educação da criança pequena e sua vulnerabilidade;

2. Das características das tarefas no sentido abrangente do papel de educador da infância:

3. Da infância baseada em uma rede de interações alargadas

No que concerne às especificidades do fazer docente da educação infantil e em particular, com as crianças entre zero e três anos, Ortiz e Carvalho (2012) consideram fundamental no exercício da formação contínua dos professores que eles desenvolvam a capacidade de observação e de reflexão sobre a prática sob cinco aspectos fundamentais:

1. Desenvolvimento da compreensão dos bebês pelos adultos em uma relação recíproca de comunicação na qual o educador capta o que eles sentem e dá sentido à comunicação;

2. Construção de vínculos para que os bebês sintam-se seguros e pertencidos a um contexto particular com pessoas que lhe garantam segurança;

3. Aprender a interagir com os bebês reconhecendo sua capacidade de perceber as diferenças entre as pessoas e relacionarem-se com elas de forma diferente;

4. Aprender a se comunicar e valorizar as formas de contato comunicativo que os bebês estabelecem por meio das emoções, movimentos corporais e mais tarde por meio das palavras; 
5. Reconhecer a imitação como instrumento imprescindível e potente para a construção e diferenciação eu/outro.

Decorrente do que foi abordado até aqui é fundamental que a formação dos professores da educação infantil nas modalidades de formação inicial e continuada mantenha o diálogo entre a teoria e a prática, pautado pelos percursos pessoais dos profissionais e pelas especificidades da profissionalidade de professores dessa faixa etária. Pinazza (2004) sugere uma nova concepção de formação a partir da prática em contexto, inspiradas na visão ecológica de desenvolvimento proposto por Bronfenbrenner. A autora diz que:

\footnotetext{
Adotar uma perspectiva ecológica, de contextos integrados, implica admitir o surgimento de outras lógicas regentes do trabalho docente e dos cursos de formação: a lógica da uniformização cede lugar à lógica da diversidade de práticas; a lógica da soberania dos centros formadores sobre os saberes cede espaço à lógica da parceria entre os centros formadores e o sistema de serviços (unidade institucional e outras instâncias do sistema), e a lógica dos programas de pesquisa e intervenção em grande extensão abre espaço para uma outra lógica: do estudo e da intervenção em profundidade (PINAZZA, 2004, p. 383).
}

Nessa proposta da formação em contexto é imprescindível que as formações valorizem as experiências dos diferentes ciclos de vida relacionadas aos contextos que se inserem, aliando formação-investigação-ação (PINAZZA, 2004). Valorizar as experiências é também entendido segundo a proposta de LARROSA (2004), que define a experiência como aquilo que nos acontece e o modo como lhe atribuímos sentido. Segundo o autor, a experiência não se repete, tem sempre uma dimensão da incerteza e não se pode antecipar o resultado, dessa forma não é uma meta que se conhece, mas uma abertura ao desconhecido. Uma mesma experiência é sempre diferentemente vivida por pessoas distintas, o que atribui ainda mais sentido em pensar a formação de professores segundo as identidades dos profissionais que nelas atuam, reconhecendo seu saber e fazendo do par teoria/prática um espaço de reflexão sobre a prática.

\subsection{Entre olhares, gestos e silêncios: o que é escutar as crianças bem pequenas}

Ao pensarmos no bebê há que se ter clara a dimensão de que existe sempre um outro junto com ele em vários processos que se articulam para sua existência. Tais processos 
envolvem aspectos de condições ambientais (ambiente físico, material, temporal e relacional), condições orgânicas (constituição e funcionamento físico e fisiológico do bebê) e condições simbólicas que o determinam (lugar que ocupa na família, mitos familiares, ações realizadas em função do bebê, o que se fala dele, os sujeitos desses discursos). Como dizem Ortiz e Carvalho (2012),

Não podemos nos limitar a dizer que basta cuidar e responder as necessidades físicas de um recém-nascido para que ele cresça saudável, pois não basta um corpo saudável, biologicamente organizado e programado para funcionar; é preciso ocupar-se dele, atribuir significados, responder às suas primeiras demandas, ter expectativas sobre suas ações e reações, e situá-los na cultura por meio do desejo daqueles que cuidam dele (p. 32).

Considerar este campo relacional do bebê com o outro, significa reconhecer o valor das interações como aspecto fundamental do desenvolvimento humano. Não se pode falar em desenvolvimento individual e linear nem tampouco desconsiderar o contexto relacional do bebê que o faz existir ao construir sua identidade e subjetividade. O desenvolvimento é um processo contínuo de estruturações, desequilíbrios e reestruturações, em busca da própria identidade que se dá em contextos sócio-históricos particulares, em redes de relações e no jogo das interações (CARVALHO; PEDROSA; ROSSETI-FERREIRA, 2012).

O discurso sobre os bebês geralmente se remete ao desenvolvimento como aquisição de habilidade, porém Ortiz e Carvalho (2012) e Carvalho, Pedrosa e Rosseti-Ferreira (2012) destacam a necessidade de ir além, concebendo o desenvolvimento como processo e não apenas produto. No âmbito do desenvolvimento existe sempre uma flexibilidade que é modulada pelo ambiente. Para além de se perguntar "o quê" ou "quando", é preciso questionar-se sobre o "como" para dessa forma ampliar o sentido do desenvolvimento para os processos que têm em seu centro as redes de interações dos bebês com o meio e com os outros.

As mesmas autoras enfatizam que para compreender esses processos é fundamental que sejam aguçados a escuta e o olhar para as crianças, localizando o educador como uma das faces do outro primordial. Qual é a qualidade de nossa observação? O que de fato vemos e ouvimos?

É importante refletirmos criticamente sobre o ato de ver como ação mecânica do exercício do sentido da visão. Cardoso (1988) discute a relação entre ver e olhar quando considera que:

Ela, a simples visão, supõe e expõe um campo de significações, ele, o olhar - necessitado, inquieto e inquiridor - as deseja e procura, seguindo a trilha do sentido. O olhar pensa; é a visão feita interrogação (p. 349). 
É a esse olhar pensante e questionador que se refere a observação e a escuta das crianças, um olhar que reflete e compreende os processos do bebê quando reconhece nele um ser ativo que por meio de suas linguagens interage com o mundo. Aqui, deve-se entender linguagem para além do falar convencionalmente e sim como um sistema de comunicação que se manifesta com ou sem palavras. O corpo, os gestos, o olhar, o choro, as vocalizações, o silêncio instrumentalizam a comunicação do bebê que é interpretada pelo adulto que age em função do sentido que dá a ela. É sobre isso que nos referimos quando falamos da escuta das crianças.

A pedagogia da escuta (HOYUELOS, 2004) coaduna-se com a posição defendida sobre o olhar qualificado para os bebês. Hoyuelos (2004), ao definir a escuta como uma das estratégias do princípio ético de Loris Malaguzzi, atenta para o fato de que falamos muito sobre as crianças, mas falamos pouco com elas e muito menos as escutamos. Escuta entendida em seu aspecto estético e relacional, dar ouvidos a todos os sentidos e escutar as relações das crianças com o mundo. Ao escutar evitamos generalizações, damos identidade, reconhecemos que cada um é único e tiramos as crianças das condições desenvolvimentistas que visam resultados e não os processos (CARVALHO; PEDROSA; ROSSETI-FERREIRA, 2012).

Escutar os bebês é ainda mais desafiante porque requer que agucemos todos os nossos sentidos e suspendamos nossas ideias pré-estabelecidas a respeito de sujeitos que ainda não verbalizam convencionalmente. É preciso que nos permitamos o assombro, a maravilha, a reflexão e a alegria, premissas para a observação adequada, a interpretação e a metacognição (HOYUELOS, 2004).

Quanto mais se valorizar o bebê, suas especificidades e se construir uma pedagogia específica para essa faixa etária, melhores serão os atendimentos para zero a três anos. Compreendê-los por meio da escuta e da observação qualificada é marca fundamental nesse processo, que pode ter como sua aliada a prática da documentação pedagógica.

Azevedo e Sousa (2010) colocam a documentação pedagógica como um dos três pilares que sustentam a pedagogia em creche associada à qualidade e à diversidade. As autoras assumem a imprescindível necessidade de leitura das múltiplas linguagens traduzindo a pedagogia em creche como uma:

[...] pedagogia de suspensão que obriga o educador a suspender-se para escutar os sinais da(s) criança(s) e nessa escuta dar a vez aos seus sentires e saberes (Oliveira-Formosinho, 2010). A documentação em creche implica a leitura de outras linguagens, que não a convencional, para visibilizar os processos de aprendizagem da criança pequena. Esta é uma opção 
claramente assumida na Pedagogia-em-Participação (AZEVEDO; SOUSA, 2010, p. 14).

O poder comunicacional da documentação, que promove o diálogo, constrói comunidades de aprendizes, cria laços, partilha experiências e significados, se constitui, essencialmente, a partir da escuta e, no caso de seu uso nas creches, ela pode significar um valoroso recurso para ampliação da leitura dos olhares, gestos, silêncios e tantas outras formas de se comunicar que os bebês exercitam dia a dia. 


\section{PESQUISA DE CAMPO}

\subsection{Circunstâncias contextuais}

A instituição pesquisada, localizada na cidade de São Paulo, é uma creche universitária, com uma edificação composta por três pavimentos. O primeiro compreende as áreas administrativas como recepção, secretaria, salas de coordenação e orientação, enfermaria, além da cozinha, lactário, sala dos funcionários e banheiros para adultos. $\mathrm{O}$ segundo e terceiro pavimentos são ocupados por ambientes destinados às práticas com as crianças. Reunindo esses dois pavimentos, tem-se um grande pátio coberto: de um lado temos o Módulo I (atendimento de crianças entre 0 e 3 anos) e, do outro lado, o Módulo II (atendimentos de crianças entre 4 a 6 anos). As áreas externas são amplas e compostas por um grande parque com areia e brinquedos diversos; um espaço de horta e plantio; outro pátio com areia e uma casinha, além de pequenas varandas anexas a cada sala de atividades.

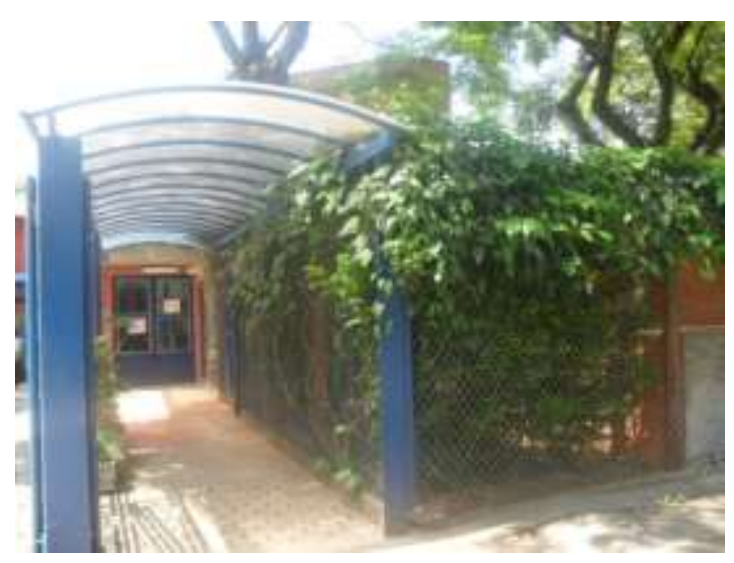

Figura 3 - Entrada da creche vista de fora

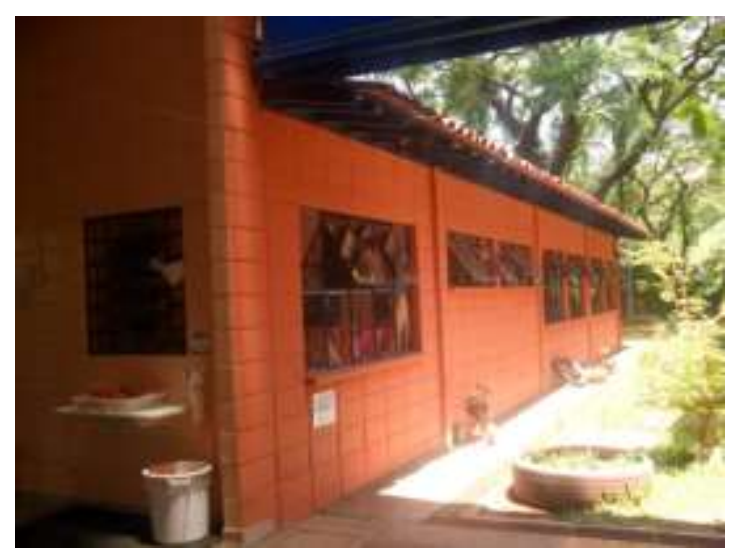

Figura 5 - Módulo I

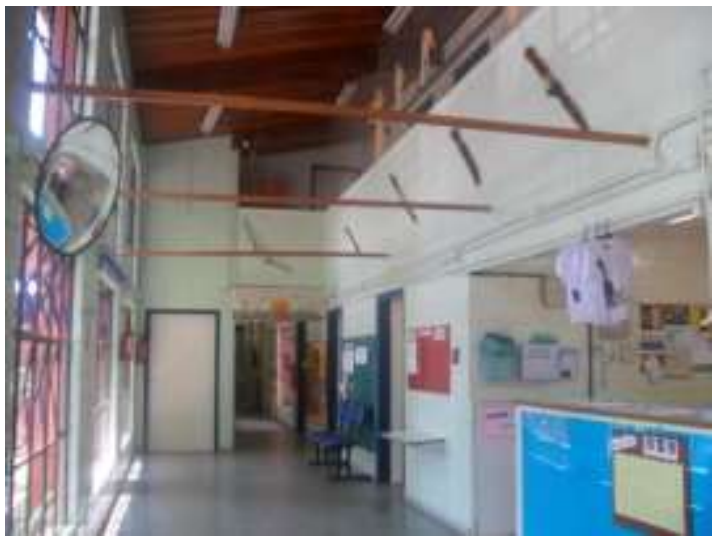

Figura 4 - Entrada da creche interna

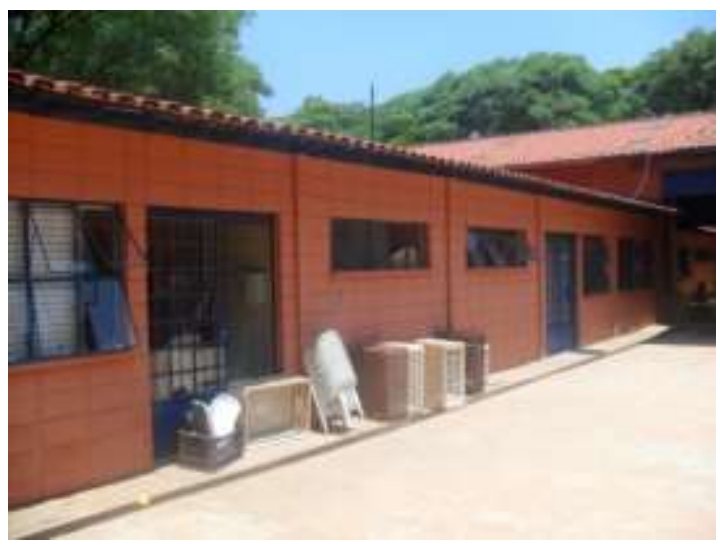

Figura 6 - Módulo II 


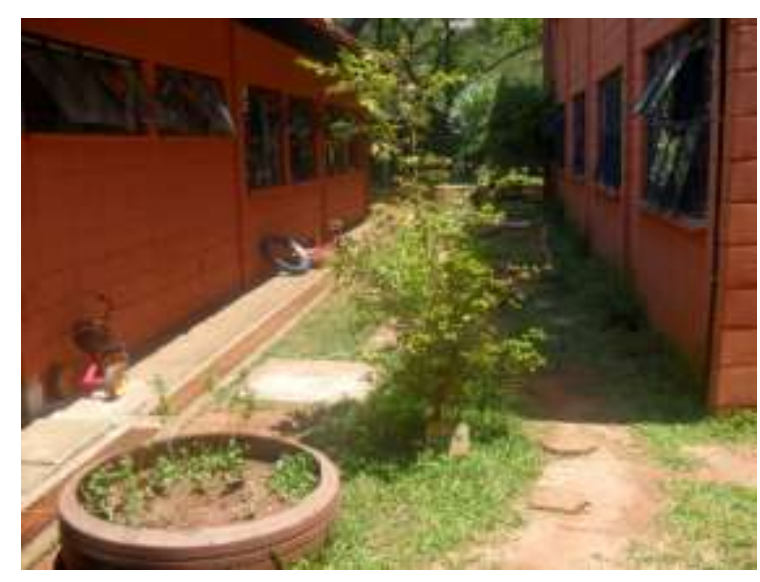

Figura 7 - Espaço de horta e plantio

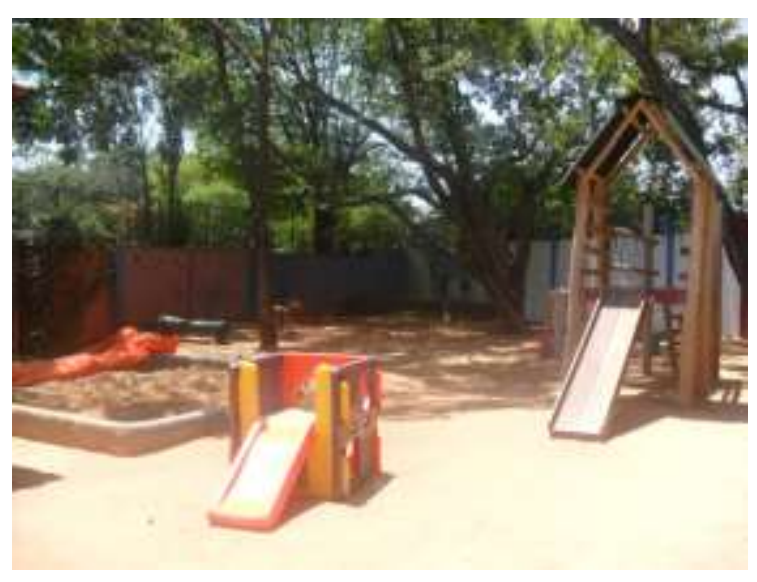

Figura 8 - Parque

Ao longo de 20 anos, os grupos foram identificados por: berçário, Grupo 2, Grupo 3, Grupo 4, Grupo 5 e Grupo 6. A nomenclatura dos grupos correspondia à faixa etária que atendia as crianças, porém, a partir de 2011, os nomes foram reformulados de acordo com as cores primárias e secundárias pelo fato de a nomenclatura anterior não incluir o berçário da mesma maneira, além das mudanças na legislação sobre a entrada das crianças no ensino fundamental, o que descaracterizava a nomenclatura dos agrupamentos e sua correspondência à faixa etária que atendia. Atualmente os grupos são organizados da seguinte forma:

Tabela 1 - Agrupamentos

\begin{tabular}{ccc}
\hline \multicolumn{3}{c}{ Agrupamentos da creche } \\
\hline & Módulo I (4 meses a 3 anos) \\
\hline Grupo Azul & $\mathbf{N}^{\mathbf{0}}$ de crianças & Faixa etária \\
\hline Grupo Verde & 14 & 4 meses a 1 ano \\
Grupo Amarelo & 15 & 1 ano a 2 anos \\
& 15 & 2 a 3 anos \\
\hline Grupo Vermelho & Módulo II (3 a 6 anos) & \\
Grupo Laranja & $N^{\circ}$ de crianças & Faixa etária \\
Grupo Roxo & 20 & 3 a 4 anos \\
\hline
\end{tabular}


A pesquisa focalizou o Módulo I, especialmente os grupos Azul e Verde. Contudo, os dados produzidos em 2012 e que serão analisados neste estudo referem-se ao, então, agrupamento Azul.

$\mathrm{O}$ atendimento na creche se faz em período integral ou em meio período, ficando a critério das famílias definirem o tempo de permanência de seus filhos na creche que funciona das $7 \mathrm{~h} 00$ às $18 \mathrm{~h} 30$. A unidade mantém uma rotina planejada e bem estruturada que combina tempos de propostas educativas (como o trabalho com projetos, as brincadeiras) e momentos de cuidado e assistência (como as refeições, sono e higiene). A rotina é descrita pela tabela abaixo, fornecida pela própria instituição:

Tabela 2 - Quadro de rotina Módulo I: Grupos Azul, Verde e Amarelo

\begin{tabular}{|c|c|}
\hline Horário & Atividade \\
\hline & Azul: Proposta na casinha \\
\hline $7 \mathrm{~h} 00$ & Verde e Amarelo: ateliês \\
\hline $8 \mathrm{~h} 30$ & Verde e Amarelo: Roda na sala \\
\hline $8 h 45$ & Lanche \\
\hline 9h00 & Pátio \\
\hline 10h00 & Momento de grupo \\
\hline $10 h 45$ & Azul: Almoço, escovação e descanso \\
\hline $11 \mathrm{~h} 15$ & $\begin{array}{l}\text { Verde e Amarelo: Almoço, escovação e } \\
\text { descanso }\end{array}$ \\
\hline $13 h 15$ & Ateliês \\
\hline $13 h 45$ & Azul: lanche \\
\hline $14 h 15$ & Verde e Amarelo: lanche e escovação \\
\hline $14 h 30$ & Pátio \\
\hline $15 h 30$ & Momento de grupo \\
\hline $16 \mathrm{~h} 00$ & $\begin{array}{l}\text { Verde e Amarelo: propostas na sala e arrumação } \\
\qquad \text { das mochilas }\end{array}$ \\
\hline $16 h 45$ & Jantar \\
\hline
\end{tabular}




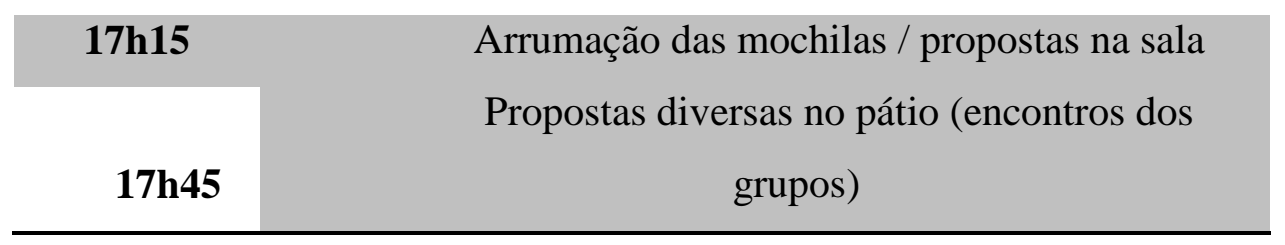

O Grupo Azul, no qual a pesquisa se concentrou, era composto por 14 crianças que completaram um ano durante o ano letivo de 2012, sob a responsabilidade de seis educadoras, que dividiam a docência em dois períodos de seis horas, cada um com três educadoras; e uma estagiária que permanecia no grupo no período das $10 \mathrm{~h} 00$ às $16 \mathrm{~h} 00$. O estudo focalizou o período da tarde, envolvendo, portanto, o acompanhamento da prática de três das seis educadoras do agrupamento.

\subsection{Sobre as educadoras envolvidas na pesquisa}

Esta pesquisa acompanhou o trabalho de três educadoras que têm seus percursos na carreira docente distintos, o que contribui para uma parceria interessante. Elas vivem tempos diferentes na carreira de professor e a título de garantir a privacidade, as educadoras serão citadas pelas suas iniciais.

O trio de educadoras atuantes no período da tarde, no grupo Azul, é marcado por algumas diferenças de trajetória de formação e de profissão que puderam ser apreendidas nas entrevistas realizadas. A educadora "L" tem uma grande experiência da prática, a educadora "M", apesar do pouco tempo de atuação com bebês, tem um percurso formativo acadêmico constantemente permeado por novos cursos e a educadora "S", além de novata na creche, ainda tem uma trajetória recente na carreira docente, mas nem por isso de menor qualidade.

O que é fortemente notado nas três educadoras, a partir do acompanhamento de suas práticas e das entrevistas realizadas, é a identificação pessoal com o trabalho com bebês, o que determinou a escolha que fizeram em trabalhar com essa faixa etária. Esse é um fato relevante, posto que, por vezes, nas instituições de educação infantil as crianças menores são vistas como menos potentes e tendem a compor os grupos menos desejados de atuação dos educadores. Nos relatos ${ }^{7}$ das três educadoras envolvidas nesta pesquisa, elas falam do gosto pelo trabalho com bebês e de sua opção pela faixa etária.

\footnotetext{
${ }^{7}$ Nas transcrições das falas foi preservada a linguagem coloquial.
} 
Educadora "L": tem 52 anos, está na creche há 20 anos e construiu praticamente toda sua carreira nesta instituição, tendo trabalhado somente um ano em outra instituição. Dos 21 anos de carreira trabalhou somente 5 anos com crianças maiores, tendo 16 anos de atuação em berçário. Cursou o magistério e há dois anos concluiu a graduação em Pedagogia. É uma das educadoras mais antigas da creche e orgulha-se de ter acompanhando todo o processo da instituição ao longo do tempo.

Algumas vezes eu optei por continuar no berçário, aqui na creche somos consultadas sobre qual grupo queremos ficar. (...) Escolho os bebês porque me identifico bastante, eu tenho um olhar assim... bem mais cuidadoso, eu coloco uma lupa no dia-a-dia mesmo, do cuidar e educar que estão bem juntos. Ao mesmo tempo em que você tem um trabalho, um projeto, você também tem o outro olhar em situações de brincadeiras, nos tipos de materiais que você está utilizando. Tem que ter um certo cuidado de saber como você vai oferecer este material, em que espaço, como organizar o chão, a mesa ou o gramado.

Entrevista educadora "L"

Educadora "M": tem 47 anos, está na creche há 12 anos, mas atua com educação infantil há 23 anos. É graduada em pedagogia e tem duas especializações em artes e psicopedagogia. Já atuou com diversas faixas etárias, mas a maior parte do tempo com crianças pequenas até três anos. Está no berçário há dois anos.

É uma faixa que me fascina bastante, eu gosto muito. Acho que essa primeira faixa de zero a três é super parecida, os bebês tem uma delicadeza maior, mas eles são todos delicados até o amarelinho ${ }^{8}$. Eu gosto de todos e mesmo dos maiores. (...) É que os bebês têm uma delicadeza porque estão chegando, se adaptando, mas depois que se adaptam... você já percebeu como eles vão ficando super sossegados... Aqui na creche as escolhas dos grupos vão um pouco pela experiência dos educadores. Os bebês são uma faixa que você tem que ter gosto para atender e uma certa técnica aprimorada porque se é uma pessoa inexperiente ela pena um pouco, então a composição é um pouco desse jeito: tem que ser pessoas que já tenham alguma bagagem.

Entrevista educadora "M"

Educadora "S": tem 31 anos, é formada em pedagogia e escolhe esta carreira durante sua graduação em Letras quando, ao trabalhar com crianças em projetos de ludo

\footnotetext{
${ }^{8}$ Ao dizer "Amarelinho", refere-se ao Grupo Amarelo, último agrupamento do Módulo I, que atende as crianças entre 2 e 3 anos.
} 
educação, interessa-se pela área da educação. É a educadora mais recente na creche com menos de um ano na instituição. Além dos trabalhos realizados com crianças maiores em instituições não escolares ela atua há três anos na educação infantil em turmas de berçário.

Quando cheguei aqui na creche já era novembro então a creche estava resolvida, já estavam finalizando os trabalhos e o espaço que precisava de mais apoio era o Grupo Azul (...). Fiquei por um mês e meio no Grupo Azul e estava bem feliz lá. Para este ano não pedi nenhum grupo porque aqui na escola tem esse movimento de pedir a alocação. Às vezes você consegue, às vezes não, mas eu não cheguei a pedir, me colocaram e eu fiquei satisfeita.

Entrevista educadora "S"

\subsection{Produção de dados}

A atuação na creche enquanto pesquisadora deu-se em dois momentos: primeiramente, uma entrada de inspiração etnográfica para aproximação e conhecimento do contexto da instituição no ano de 2011. Durante dois meses foram feitas visitas sistemáticas em um agrupamento do Módulo I, o Grupo Verde, que na ocasião era composto por 15 crianças que completaram 2 anos durante o ano letivo de 2011 e quatro educadoras que se dividiam em duas duplas por dois períodos de seis horas. O período acompanhado foi sempre o vespertino, que contava ainda com a presença de uma estagiária volante no Módulo I que ficava parte da tarde acompanhando o Grupo Verde. Durante este período a estratégia de coleta de dados concentrou-se em observações da rotina do grupo sistematizadas em um diário de campo.

Ao longo dos dois meses de imersão em campo, ainda que se reconheça o pouco tempo e a insuficiência de dados para considerar uma análise etnográfica, a inspiração dessa metodologia de pesquisa para a primeira aproximação com a instituição mostrou-se eficaz para compreender o seu contexto e a potência de desenvolvimento de uma pesquisa mais ampla no ano subsequente. Ao longo das observações realizadas em 2011 foi possível perceber a concepção do trabalho com as crianças a que a creche se propõe.

A entrada em campo pouco interferiu na rotina das crianças que já estavam bem familiarizadas com o ambiente escolar e acostumadas com a presença de pesquisadores, visto 
que não foi percebido nenhum estranhamento inicial das crianças com a presença da pesquisadora nos espaços. Não que a pesquisadora não fosse notada pelas crianças, mas essa presença era muito natural para elas. As crianças transitavam pelos espaços, faziam suas escolhas, as educadoras interagiam com elas, atendiam as que precisavam de ajuda e, vez ou outra, conversavam com a pesquisadora para explicar algo específico que acontecia. Outras vezes a própria pesquisadora perguntava e elas, sempre muito atenciosas, respondiam todas as dúvidas, desde que não prejudicasse sua atenção para com as crianças. A naturalidade com a presença de uma pessoa estranha permeou todas as demais visitas à creche e essa tranquilidade das crianças com a pesquisadora pode ser explicada por conta das frequentes visitas que a instituição recebe periodicamente. Por ser uma creche universitária e desenvolver um trabalho de qualidade, conforme a coordenadora conta, é comum receber visitas de grupos de estudantes de pedagogia, pesquisadores dessa e de outras universidades, além de representantes de outras instituições dedicadas à primeira infância que buscam no trabalho dessa creche inspiração para seus projetos educativos.

Durante as observações pôde-se conceber a rotina das crianças mais ampla do que seus grupos etários, ou seja, apesar de as crianças estarem divididas por faixa etária, em diversas situações havia momentos de integração entre os outros grupos. Cada grupo não se restringia à sua sala e às suas professoras (o que infelizmente é bastante comum em instituições de educação infantil), mas estavam a todo tempo se relacionando com crianças de outros grupos, outros educadores, bem como demais funcionários da creche.

A concepção do trabalho educativo da creche é evidenciada em todas as ações com as crianças e durante a imersão de inspiração etnográfica foi possível compreendê-lo. Após esse primeiro período na creche, ao final do ano de 2011, foi estabelecido com a equipe gestora um plano de trabalho para 2012, que em comum acordo previa uma intenção de pesquisa-ação na qual a pesquisadora analisaria as práticas de registro e participaria das formações das educadoras com vista a contribuir qualitativamente para a produção desses registros, sustentando a prática da documentação pedagógica com bebês. Alguns impedimentos por parte de questões internas e de organização da creche impossibilitaram a execução do cronograma de atuação da pesquisadora, que previa sua entrada em campo a partir de janeiro de 2012. O início da pesquisa efetivou-se com algumas reuniões com a equipe gestora nos meses de março e abril, mas só ganhou realmente força a partir de maio. Com isso, houve algumas perdas que se não tivessem acontecido seria de grande valia para as análises da pesquisa como, por exemplo, o acompanhamento do "período de adaptação" e a construção dos primeiros registros das educadoras. $\mathrm{O}$ acompanhamento realizou-se no 
restante do ano, mas a intervenção da pesquisadora ficou limitada, restringindo-se a entradas pontuais que não se configuraram como uma pesquisa-ação e sim como uma pesquisa de observação participante.

Durante as inserções em campo no ano letivo de 2012, o trabalho investigativo consistiu nas seguintes ações:

1. Análise de materiais produzidos pela creche em diferentes anos para compreender o que produziam de registros e/ou documentação (fotografias, vídeos, pastas-memória, relatórios de grupo, planejamentos);

2. Entrevistas com as educadoras;

3. Observações do dia-a-dia da prática com as crianças, sistematizadas em um diário de campo;

4. Relatos das famílias escritos durante o "período de adaptação" produzido pela creche e enviado às famílias;

5. Acompanhamento de uma reunião de formação com a coordenadora pedagógica;

6. Acompanhamento da Reunião de pais de final de ano;

7. Acompanhamento do processo de organização da exposição de final de ano.

\subsubsection{Primeira etapa de inserção no campo}

Com o intuito de compreender o contexto da creche a partir da apropriação da rotina, foram realizadas visitas sistemáticas durante dois meses. Cada visita durava cerca de duas horas e acontecia em horários diversos, na tentativa de acompanhar momentos diferentes da rotina. Com o tempo os momentos da rotina observados repetiam-se, o que contribuiu pra a compreensão da pesquisadora do contexto da creche. 
Tabela 3 - síntese das observações realizadas na primeira inserção no campo

\begin{tabular}{|c|c|c|c|}
\hline $\begin{array}{c}\text { Número } \\
\text { da } \\
\text { observação }\end{array}$ & Data & $\begin{array}{c}\text { Duração } \\
\text { da } \\
\text { observação }\end{array}$ & Descrição \\
\hline 1 & $06 / 05 / 2011$ & $2 \mathrm{~h} 30$ & Ateliês, lanche, escovação e parque \\
\hline 2 & $13 / 05 / 2011$ & $2 \mathrm{~h} 00$ & $\begin{array}{l}\text { Ateliê, lanche, sala faz de conta, proposta de } \\
\text { cantos na sala ambiente }\end{array}$ \\
\hline 3 & $20 / 05 / 2011$ & $1 \mathrm{~h} 45$ & Lanche, pátio, proposta na sala faz de conta \\
\hline 4 & $27 / 05 / 2011$ & $1 \mathrm{~h} 30$ & Ateliê, lanche, escovação, pátio \\
\hline 5 & 02/06/2011 & $1 \mathrm{~h} 50$ & Lanche, pátio, proposta no solário \\
\hline 6 & 09/06/2011 & $2 \mathrm{~h} 45$ & $\begin{array}{c}\text { Exposição adaptação, lanche, proposta no pátio } \\
\text { coberto, roda, atividade do projeto na sala } \\
\text { ambiente }\end{array}$ \\
\hline 7 & $22 / 06 / 2011$ & $2 \mathrm{~h} 00$ & $\begin{array}{c}\text { Ateliê, lanche, pátio, atividades da festa junina, } \\
\text { brincadeiras na sala ambiente }\end{array}$ \\
\hline 8 & $29 / 06 / 2011$ & $2 \mathrm{~h} 10$ & $\begin{array}{l}\text { Lanche, pátio, teatro, roda de história, ensaio } \\
\text { para festa junina, descanso, jantar }\end{array}$ \\
\hline
\end{tabular}

\subsubsection{Segunda etapa de inserção no campo}

Após a primeira etapa de aproximação da unidade, em 2011, ficou combinada a continuação da pesquisa para o ano de 2012, ressaltando o interesse da pesquisadora pela temática da documentação pedagógica. A equipe gestora manifestou, desde o primeiro momento, grande motivação pelo estudo desse tema, posto que a creche já vinha se dedicando ao assunto há cerca de três anos. Com isso, apostavam em uma parceria da pesquisadora na prática formativa das educadoras. Contudo, essa perspectiva de atuação, com intervenção no contexto pesquisado, não se efetivou na prática por questões de organização da creche, em especial a falta de tempo dentro do período de trabalho das educadoras para que fossem realizadas discussões e formações. A intenção inicial de desenvolver uma pesquisa-ação não se concretizou e o trabalho investigativo constou, essencialmente, de um acompanhamento do 
trabalho das educadoras para compreender as concepções de registros e documentações que produziam, nos moldes de uma observação participante.

A escolha feita pela pesquisadora em desenvolver o estudo em um agrupamento de bebês foi prontamente acolhida pela instituição e, assim, a pesquisa realizou-se no Grupo Azul, formado por crianças de idades entre 4 meses e 1 ano.

As vivências na creche possibilitaram algumas percepções sobre o trabalho com relação ao tema dos registros e da documentação. Ficou evidente a prática das educadoras com registros sistemáticos de suas ações com as crianças e estes abrangem:

- registros que envolvem informações mais objetivas das crianças e são realizados diariamente como, por exemplo, uma tabela afixada na porta da sala que contém informações sobre alimentação, cuidados e higiene que as famílias podem consultar diariamente ao final do período;

- caderno de anotações em que as educadoras fazem breves anotações das crianças relacionadas ao seu desenvolvimento na creche, progressos, crescimento. É utilizado especialmente para registrar aspectos das crianças durante o período de adaptação e tais registros são resgatados ao final do ano letivo para a elaboração do relatório individual da criança que é entregue às famílias;

- registros reflexivos (como o relatório de grupo, as pastas-memória, os planejamentos);

- registros de natureza audiovisual e imagética (como os vídeos, as fotografias e a exposição).

No intuito de analisar a relação entre os registros produzidos, a possível prática da documentação pedagógica e a concepção de infância, que estaria subjacente, as perguntas iniciais do processo buscavam compreender: Como os registros periódicos evidenciam o olhar para os bebês? Como os registros podem se transformar em documentações pedagógicas com vistas ao planejamento e à avaliação das práticas? Como as documentações pedagógicas estão a serviço da prática reflexiva do professor?

Para a busca de possíveis respostas a essas questões foi realizada uma imersão em campo ao longo do ano letivo de 2012, que envolveu visitas sistemáticas à creche, conversas com a coordenadora pedagógica, acompanhamento de algumas atividades do Grupo Azul, leitura e análise dos registros produzidos pelas educadoras, acompanhamento dos 
planejamentos, acompanhamento da montagem da exposição, participação em uma reunião de pais e em uma reunião de formação com as educadoras. Tais ações estão sistematizadas resumidamente no quadro abaixo:

Tabela 4 - síntese das ações durante a inserção no campo (ano de 2012)

\begin{tabular}{|c|c|c|}
\hline $\begin{array}{l}\text { Número } \\
\text { da ação } \\
\text { em campo }\end{array}$ & Data & Descrição das atividades desenvolvidas \\
\hline 1 & $05 / 12 / 2011$ & $\begin{array}{l}\text { Conversa com a coordenadora e definição do início da pesquisa } \\
\text { para o ano seguinte }\end{array}$ \\
\hline 2 & 08/03/2012 & $\begin{array}{c}\text { Conversa com a coordenadora e organização das ações para o } \\
\text { semestre }\end{array}$ \\
\hline 3 & $15 / 03 / 2012$ & Análise dos registros do Grupo Azul de anos anteriores \\
\hline 4 & $22 / 03 / 2012$ & Análise dos registros do Grupo Azul de anos anteriores \\
\hline 5 & $07 / 05 / 2012$ & $\begin{array}{l}\text { Encontro com a coordenadora, nova organização para entrada } \\
\qquad \text { em campo }\end{array}$ \\
\hline 6 & $06 / 06 / 2012$ & Acompanhamento da rotina do Grupo Azul \\
\hline 7 & $13 / 06 / 2012$ & Acompanhamento da rotina do Grupo Azul \\
\hline 8 & 26/06/2012 & $\begin{array}{c}\text { Acompanhamento da rotina do Grupo Azul / leitura dos } \\
\text { planejamentos iniciais }\end{array}$ \\
\hline 9 & $15 / 08 / 2012$ & $\begin{array}{l}\text { Encontro com a coordenadora para nova organização da entrada } \\
\qquad \text { em campo }\end{array}$ \\
\hline 10 & $19 / 09 / 2012$ & Leitura dos planejamentos seguintes \\
\hline 11 & 20/09/2012 & Realização das entrevistas com as educadoras \\
\hline 12 & 26/09/2012 & $\begin{array}{l}\text { Acompanhamento do planejamento das educadoras e término } \\
\qquad \text { das entrevistas }\end{array}$ \\
\hline 13 & $03 / 10 / 2012$ & Acompanhamento de atividade do projeto \\
\hline 14 & $17 / 10 / 2012$ & Acompanhamento de atividade do projeto \\
\hline 15 & $24 / 10 / 2012$ & Acompanhamento de atividade do projeto \\
\hline 16 & 29/10/2012 & Acompanhamento de encontro de formação das educadoras \\
\hline 17 & $31 / 10 / 2012$ & Leitura dos registros das famílias \\
\hline 18 & $07 / 11 / 2012$ & Acompanhamento de atividade do projeto \\
\hline 19 & $22 / 11 / 2012$ & Acompanhamento da montagem da exposição de artes \\
\hline
\end{tabular}


23/11/2012 Acompanhamento da montagem da exposição de artes / reunião de pais

\section{26/11/2012 Acompanhamento da montagem da exposição de artes}

$22 \quad 27 / 11 / 2012$

Abertura da exposição de artes

23 Dez/2012 a

Análise da pasta memória do grupo Azul

$\mathrm{Jan} / \mathrm{Fev} / 2013$

É importante pontuar que, como última ação da pesquisa, previa-se entre o final do ano letivo de 2012 e início do ano subsequente o acompanhamento da produção da pastamemória do grupo, conforme está apontado na tabela acima. Contudo, esse material não foi produzido. O que se pode analisar com relação às pastas-memória da creche está vinculado a materiais desse gênero produzidos em outros anos.

Para melhor entendimento, optou-se por apresentar os dados segundo três eixos de referência, a saber.

A. Dados documentais: constituídos por todos os documentos produzidos pela creche a que a pesquisadora teve acesso.

B. Dados de observação: referem-se aos dados acompanhados especialmente pelas observações da pesquisadora, que foram registrados no diário de campo.

C. Dados das entrevistas: constituídos essencialmente pelos dados colhidos por meio de entrevistas realizadas com as três educadoras, gravados e transcritos.

A seguir, são descritos os dados relativos a cada um dos três eixos.

\section{A. Dados documentais:}

\section{Fotografias e vídeos}

Há uma grande produção imagética armazenada no computador da creche e organizada por agrupamento. Muitas fotografias fazem parte desse acervo e são, por vezes, organizadas por temas como, por exemplo: "Brincando com areia", "Fazendo painel", “Intervenção no acrílico", "Explorando as texturas”. Há também pequenos extratos de vídeos 
de situações diversas também organizadas por título que sugerem as cenas, igualmente como é feito com as fotografias.

\section{Pastas-memória}

As pastas-memória são, em geral, encadernações em formato A3 que compilam o trabalho de cada grupo da creche durante o ano letivo. Costumam contemplar um dos projetos trabalhados e é constituído por imagens, fotografias, pequenos textos explicativos, poéticos ou citações de autores que referenciem o trabalho realizado. São elaborados ao término do ano letivo e muitas vezes por falta de tempo hábil são finalizados no mês de janeiro do ano subsequente.

\section{- Relatório de Grupo}

Texto composto pelas educadoras de cada agrupamento dos dois períodos, que procura retratar o desenvolvimento do trabalho durante o ano. É elaborado sempre ao final do segundo semestre e, em geral, as educadoras dividem as partes para cada uma desenvolver um dos itens que o compõem, pois é um material bastante extenso, com cerca de trinta páginas. Esse relatório traz algumas imagens que ilustram o texto e é enviado às famílias ao final do ano. A primeira página contém informações gerais da instituição, nome do agrupamento, ano letivo e imagens das crianças. A segunda página traz os nomes das crianças, das educadoras e da equipe técnica. As páginas seguintes compõem o texto em si e, especificamente, o relatório do Grupo Azul do ano de 2012 está organizado nos seguintes itens: introdução, período de adaptação, rotina, apresentação do projeto desenvolvido pelas educadoras do período da manhã e projeto desenvolvido pelas educadoras do período da tarde.

\section{- Planejamentos}

Os planejamentos na creche têm um formato bem específico e são organizados de forma que os educadores possam criar e recriar as propostas com as crianças dos projetos desenvolvidos. Consistem em uma folha impressa frente e verso que as educadoras preenchem a mão. Na frente há quatro colunas denominadas: etapa, planejamento inicial, execução e planejamento recriado. No verso há mais três colunas: etapa, registros e avaliação e dicas para recriar o planejamento. O manuseio dessa ficha de planejamento também prevê um movimento dentro de uma perspectiva flexível. Inicialmente é descrito um planejamento inicial proposto pelas educadoras. Durante a execução ou logo após a atividade 
as educadoras preenchem no verso da folha os registros da atividade, avaliam o desenvolvimento de seu planejamento inicial e apontam indícios para as próximas etapas. Nessa etapa elas voltam para frente da folha e preenchem a última lacuna "planejamento recriado", ou seja, a partir da escuta das crianças elas elaboram a próxima ação com o grupo. Este movimento de escuta é chamado por todos os educadores da creche de "dicas", ou seja, ao interpretarem as ações das crianças nas propostas inicialmente planejadas, as educadoras indicam caminhos possíveis para as próximas etapas. Durante o ano de 2012 os planejamentos acompanhados referem-se ao projeto "Ritmos coloridos" (vide anexo).

\section{Projeto Político Pedagógico}

O Projeto Político Pedagógico da creche é um documento constituído por 43 páginas que compila os princípios da creche. Inicia-se com um breve histórico da criação das creches universitárias e especialmente desta creche. A seguir discorre sobre os dispositivos legais que garante a creche como direito das crianças seguido de demais itens composto por: fins e objetivos do Projeto Político Pedagógico; concepção de criança, de desenvolvimento infantil e aprendizagem; características da população a ser atendida e da comunidade na qual se insere; regime de funcionamento; espaço físico, instalações e agrupamento; relações de recursos humanos; plano de capacitação permanente dos funcionários; parâmetros de organização de grupo e relação professor/criança; organização do cotidiano de trabalho junto às crianças; atuações das áreas de Nutrição e Saúde no trabalho da creche; proposta de articulação da instituição com a família e com a comunidade; processo de acompanhamento do desenvolvimento integral da criança; planejamento geral e avaliação institucional; e articulação da educação infantil e ensino fundamental.

No ano de 2012 estava acontecendo uma discussão acerca do Projeto Politico Pedagógico que envolvia toda a comunidade: professores, gestores, funcionários, famílias. Havia disposta uma tabela na entrada da creche na qual as pessoas se inscreviam para participar dos fóruns de discussão do currículo.

\section{Relatos das famílias}

Escritos durante o "período de adaptação". A creche costuma realizar uma pequena exposição em meados de maio sobre o período inicial das crianças em seus novos grupos. $\mathrm{O}$ Grupo Azul participa dessa exposição convidando as famílias a escreverem suas impressões sobre o período de adaptação, o início da relação com a creche e a formação do Grupo. O 
diálogo com as famílias não era o cerne da pesquisa, mas pelo fato de a instituição considerar esses relatos como formas de registros da creche eles também foram colhidos para análise da pesquisadora.

\section{B. Dados de observação}

\section{Diário de campo da pesquisadora}

Todas as visitas à creche foram descritas e sistematizadas em um diário de campo. $\mathrm{O}$ diário é composto pelas observações realizadas ao longo das duas imersões em campo entre 2011 e 2012. Sobre os dados colhidos especificamente em 2012, as observações concentraram-se no acompanhamento das atividades realizadas a partir do Projeto "Ritmos Coloridos", desenvolvido pelas educadoras como trabalho central com o Grupo Azul (vide apêndices) ${ }^{9}$.

\section{Reunião de pais}

Ao final do ano as famílias são convidadas para uma reunião onde são apresentadas as atividades desenvolvidas ao longo do semestre. É um espaço também aberto para o diálogo e apresentação das novidades do ano seguinte quando as crianças sairão do Grupo Azul e irão para o Grupo Verde. A participação da pesquisadora nessa reunião pretendeu conferir como os registros das educadoras são apresentados às famílias e na ocasião presenciou-se a apresentação de dois vídeos partilhados com os pais. Um deles, ilustrativo, era uma espécie de retrospectiva, apresentava imagens das crianças desde o início do ano, intitulado "Melhores Momentos 2012". O segundo vídeo trazia uma cena vivida durante uma das etapas do projeto no intuito de apresentar às famílias como as atividades são desenvolvidas com bebês. Esse vídeo mostra a mesma situação acompanhada pela pesquisadora no dia 7 de novembro.

\section{Processo da exposição de artes}

Ao longo do segundo semestre todos os agrupamentos expõem no saguão de entrada da creche e em uma sala multiuso uma extensa organização de imagens e objetos relativos aos projetos desenvolvidos no ano. A exposição do Grupo Azul foi realizada ao final do mês de novembro e a montagem foi acompanhada pela pesquisadora. É um momento bastante

\footnotetext{
${ }^{9}$ Devido à extensão do material colhido optou-se por trazer nos apêndices apenas um exemplar de notas do diário de campo. Todo o material encontra-se em posse da pesquisadora.
} 
relevante na creche e caracterizado pela instituição como um dos "momentos de culminância", ou seja, são produtos que encerram as ações das educadoras, mas que representam todo o processo vivido. A exposição é extremamente valorizada na creche e considerada também outra forma de registro do trabalho e diálogo com aqueles que a visitam. É a partir da exposição que as educadoras organizam posteriormente os materiais para as pastas-memória.

\section{Reunião de formação}

A creche tenta realizar sistematicamente reuniões quinzenais entre a coordenadora pedagógica e as educadoras de cada grupo, contudo, devido às questões de organização da creche que não tem esse horário de formação garantido fora do horário de atendimento às crianças, as reuniões não acontecem com a frequência desejada. Quando acontece é em geral uma breve reunião de no máximo quarenta minutos. Ao longo da pesquisa em campo foi possível somente a presença da pesquisadora em uma dessas reuniões e na ocasião as educadoras discutiram sobre a elaboração do relatório e a montagem da exposição. Houve ainda uma breve discussão sobre documentação pedagógica com bebês a partir de um texto e uma formação proposta pela pesquisadora (vide apêndices).

\section{Dados das entrevistas}

Foram realizadas entrevistas individuais semiestruturadas com as três educadoras do Grupo Azul do período da tarde para abordar temas sobre a concepção de seu trabalho e o trabalho com os registros que produziam, conforme roteiro previamente elaborado (vide apêndices). 
Tabela 5 - Eixos dos dados da pesquisa

Natureza dos dados

Tipos de Dados

\begin{tabular}{ll}
\hline & Fotos \\
Dados documentais & Vídeos \\
& Relatório de grupo \\
& Pasta-memória \\
& Planejamentos \\
& PPP \\
& Relatos famílias \\
& \\
& Observação da rotina da creche \\
& Acompanhamento do projeto \\
Dados de observação & Acompanhamento de uma reunião de pais \\
(Diário de campo) & Reunião de formação \\
& \\
& Entrevista professora $M$ \\
Dados das entrevistas & Entrevista professora $S$ \\
& Entrevista professora $L$ \\
\hline
\end{tabular}




\section{ANÁLISE DE DADOS}

O trabalho com Documentação Pedagógica pressupõe uma concepção de infância, criança e educação infantil específica, está sustentado essencialmente pelo uso dos registros e a prática reflexiva, dado que para responder às perguntas da pesquisa (Como os registros periódicos evidenciam o olhar para os bebês? Como os registros podem se transformar em documentações pedagógicas com vistas ao planejamento e à avaliação das práticas? Como as documentações pedagógicas estão a serviço da prática reflexiva do professor?) foram estabelecidas dois eixos que pretendem analisar o uso dos registros sob o viés do olhar qualificado para as crianças, como recurso para o planejamento e avaliação, e como instrumento da prática reflexiva:
a) O olhar para as crianças
b) Uso dos registros

\subsection{O olhar para as crianças}

Durante as imersões em campo os dados revelaram o trabalho cuidadoso que a creche mantém para os bebês. É possível dizer que a atuação com os bebês é de qualidade e visto que o termo 'qualidade' é polissêmico, Bondioli (2004) ressalta alguns aspectos da qualidade em contextos de educação infantil. Segundo ela, qualidade não é um valor absoluto, não é adequação a normas estabelecidas, é debate para a definição de valores, objetivos, ideias. Tem, neste sentido, natureza negociável e persegui-la implica a constante negociação entre os atores sociais que participam, por isso não há qualidade sem participação e participação implica refletir constantemente sobre o que se faz. Qualidade não é um ter de ser, é antes de tudo reflexão sobre a prática. É ainda contextual, conforme as realidades de cada instituição, e a contextualização amplia e enriquece o significado em um processo constante de (re)construção, portanto não é um produto a ser alcançado e sim coconstrução de 
significado que produz culturas específicas através das trocas, caracterizando-se como um processo formativo.

$\mathrm{Na}$ creche pesquisada a negociação sobre a prática com as crianças é discutida amplamente, dado observado através das discussões promovidas sobre o Projeto Político Pedagógico que envolvia a equipe gestora, professores, funcionários e as famílias em encontros periódicos. Durante o ano de 2012 a creche passava por uma revisão do Projeto Político Pedagógico, na entrada da instituição havia uma tabela com eixos do Projeto divididos nos quais as pessoas se inscreviam para participar do debate e refletir sobre os aspectos ali apontados. A constante reflexão sobre o que se oferece às crianças também está prevista no Projeto Político Pedagógico sob as modalidades de: jornadas de formação continuada no início de cada semestre; reuniões de grupo semanais; reuniões de módulo; reuniões das equipes de nutrição, limpeza, saúde e zeladoria; reuniões inter-equipes; reuniões extraordinárias; reuniões de supervisão; trocas informais.

Como se vê, o contexto previsto de discussão e reflexão em parceria faz parte da instituição ainda que na prática, conforme o que pode ser observado nas imersões em campo, nem sempre aconteçam com a periodicidade prevista.

Refletir sobre a qualidade na educação infantil significa se debruçar sobre a concepção que se tem de criança e nesse ponto o Projeto Político Pedagógico aponta a concepção da creche sobre as crianças consideradas potentes e protagonistas do contexto educativo que constroem seu saber nas interações com o outro, construindo uma cultura da infância:

Partimos da concepção de que a criança é um ser curioso, pensante, que produz conhecimento e cultura. À medida que pode participar de muitas brincadeiras, recriá-las, reelaborá-las e ressignificálas, apropria-se dos espaços da Creche, dos objetivos e dos brinquedos de variadas formas. Sendo assim, através da mediação do outro que ensina, aprende e faz junto, a criança constrói seu mundo de cultura, um sistema de comunicação e uma rede de significados e, portanto, expressões culturais específicas.

Projeto Político Pedagógico da Creche, p. 9

Barbosa e Ritcher (2011) enfatizam a condição de direitos das crianças e necessidade de olhares específicos para a infância, especialmente crianças bem pequenas. Especificamente sobre os bebês, o Relatório de Grupo Azul aponta que no processo de construção de conhecimento do mundo dos bebês é importante que o trabalho seja construído quotidianamente a partir da leitura das expressões das crianças: 
Entendemos que o trabalho pedagógico com crianças tão pequenas se constrói no dia-a-dia, no olhar, em torno de um gesto de afeto, nos sorrisos, nas brincadeiras e choros.

Relatório de Grupo Azul - 2012

O olhar atento e cuidadoso para com as crianças também é percebido e apontado pelas famílias como um grande ponto positivo da instituição:

Desde o primeiro dia tive certeza que a creche é o melhor lugar para deixar a minha filha. Adorei ver como todas as educadoras cuidam com todo o carinho e dedicação de todos os bebês. Mesmo no ambiente coletivo, elas conseguem perceber a individualidade de cada criança.

Relato das famílias - maio de 2012

Uma pedagogia para a pequena infância, em especial bebês, deve prever a relação entre cuidar e educar. Como aponta Kuhlmann (Apud GUIMARÃES, 2011), os cuidados muitas vezes são vistos como algo negativo devido ao histórico de vinculação das creches às concepções assistencialistas. Barbosa (2010) também defende a articulação entre cuidar e educar, entendendo:

[...] contexto do cuidado - como ato de atenção àquilo que temos de humano e singular - como de educação, processo de inserção dos seres humanos, de forma crítica, no mundo já existente (BARBOSA, 2010, p. 6).

Carvalho, Pedrosa e Rosseti-Ferreira (2012) preveem uma pedagogia para os bebês que promova as brincadeiras e interações, além das necessidades de cuidados que envolvam alimentação, higiene, rimos de atividade e repouso das crianças.

No âmbito da relação entre cuidar e educar a creche atua nas duas direções, conforme preveem o Projeto Político Pedagógico e o Relatório de Grupo:

[...] a Creche cumpre duas funções indispensáveis e indissociáveis: educar e cuidar

O conceito de educação é ampliado em nossa perspectiva, procuramos integrar o cuidado e a educação da criança. $\mathrm{O}$ cuidado não fica restrito às necessidades biológicas, mas estende-se também aos aspectos afetivos.

Projeto Político Pedagógico da Creche, p. 11 
A rotina organiza o tempo e o espaço do trabalho educativo desenvolvido com as crianças. Ela envolve os cuidados, as brincadeiras e as situações de aprendizagem orientadas.

Relatório de Grupo Azul - 2012

Barbosa (2010) aponta como componentes específicos do currículo para os bebês o ambiente como locus de ampliação das relações com o mundo a partir da imersão em experiências significativas. Três pontos fundamentais estão em jogo quando pensamos o ambiente para os bebês: o espaço, as relações e o tempo.

O espaço limpo, organizado, seguro e que garante experiências diversas foi observado na creche. A "Casinha", como é chamada a sala do Grupo Azul, é revestida por placas emborrachas que tornam o chão mais aquecido e confortável. Há também cantos aconchegantes montados com colchonetes, almofadas e na parede escaninhos que guardavam livros e fotos das famílias das crianças do grupo. No outro extremo da sala há uma estante com diversas divisões onde estão dispostos alguns brinquedos que as educadoras costumam trocar com frequência. Essa estante possibilita ainda que as crianças atravessem seus espaços a partir de suas pesquisas corporais. Alguns móbiles estão dispostos no teto e outros objetos interativos feitos de sucata ficam presos próximo às paredes das janelas. O espaço para os bebês contam ainda com uma grande área externa, banheiro, sala do sono e sala para as refeições. Durante as visitas da pesquisadora tudo esteve sempre muito limpo, ventilado e organizado de forma a manter um ambiente adequado aos bebês.

A preocupação com o espaço e os elementos que o compõem na creche está presente no Projeto Político Pedagógico, não são encarados como elementos passivos ou fixos e sim como "poderosos promotores de desenvolvimentos das crianças" (Projeto Político Pedagógico, p. 17). O mesmo documento enfatiza a qualidade dos espaços como fruto das ações intencionais dos professores e prevê a presença de espelhos, materiais e brinquedos, mobiliário adequado, além da personalização de cada sala construída conjuntamente com as crianças no início de cada ano. 


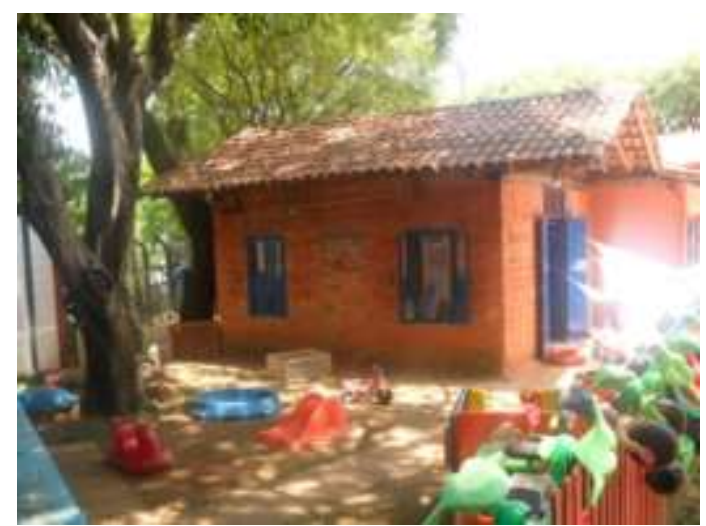

Figura 9 - "Casinha" (sala do berçário)

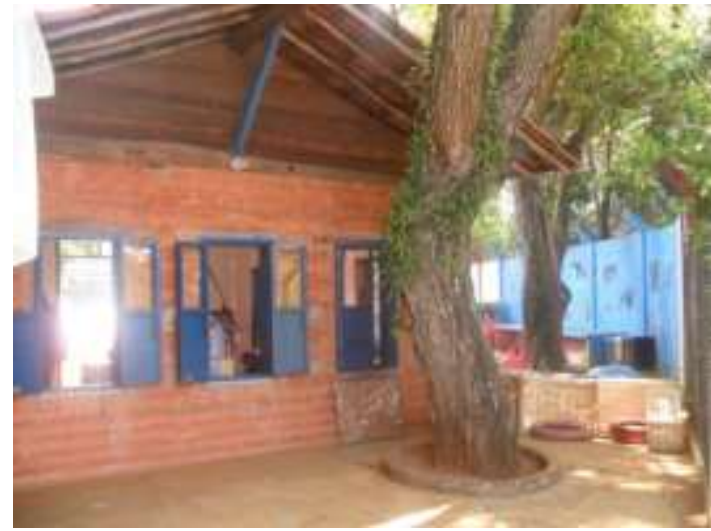

Figura 10 - "Casinha" vista de outro ângulo

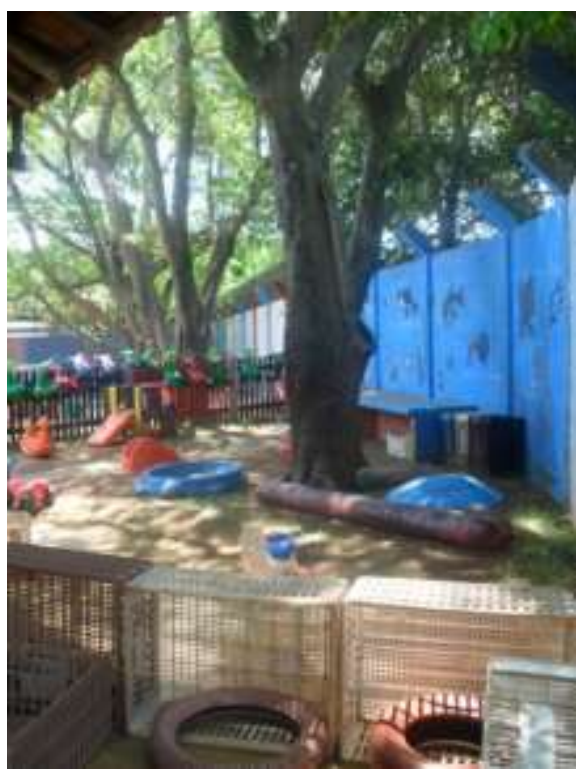

Figura 11 - Área externa saindo da "Casinha"

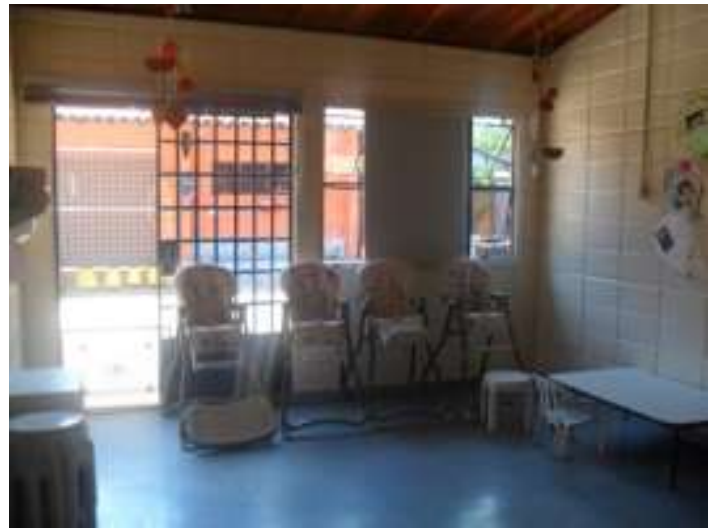

Figura 12 - Espaço para alimentação

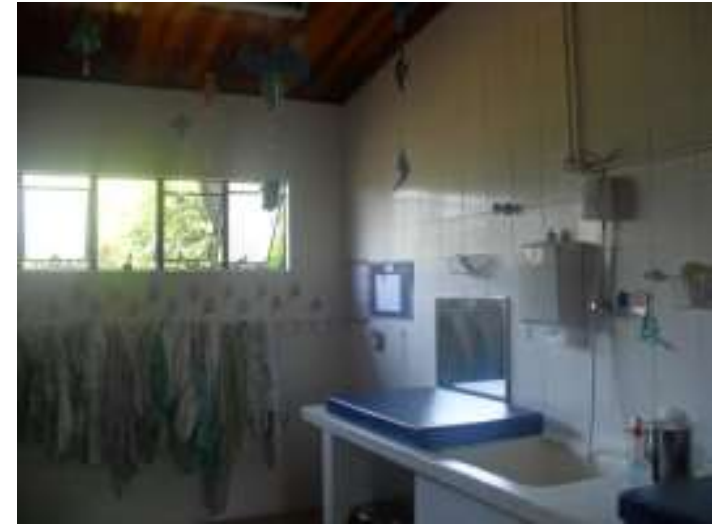

Figura 13 - Banheiro do berçário 
No que diz respeito às relações, Ortiz e Carvalho (2012) mostram a importância de os educadores perceberem a potência de suas ações na construção dos vínculos, e as relações das educadoras com os bebês da creche pesquisada evidenciaram um profundo respeito e cuidado construído desde os primeiros dias dos bebês à creche. O Relatório de Grupo enfatiza a importância dada à construção dos vínculos com os bebês por meio das brincadeiras:

É interessante ressaltar acerca da importância da construção desses vínculos que essa palavra deriva, do latim uinculum, mesma palavra que originou "brinco", de onde veio a palavra "brincar". Construção de vínculo e brincadeira têm uma relação estreita e feliz. Por isso, as brincadeiras aparecem nesse processo como elemento essencial para a recepção das crianças. Por meio das brincadeiras, os educadores começam a ouvir, sentir e compreender as expressões dos pequenos, buscando perceber de forma sensível as nuances nos brilhos de cada olhar das crianças.

Relatório de Grupo Azul 2012

Com relação ao tempo foi possível identificar a sua relação no contexto da creche em diferentes dimensões. $\mathrm{Na}$ entrevista da educadora "L" fica evidente o respeito ao tempo dos bebês para conseguir enxergar suas potências e valorizá-los em suas singularidades. Ela considera a importância de se compreender os tempos dos bebês que não são iguais aos tempos dos adultos:

Quando trabalhamos com os bebês nada acontece rápido, aos poucos você vai tendo o retorno e respeitar a criança dentro do coletivo, saber qual seu tempo de aprendizagem, saber e entender que você será seu referencial no tempo que estiver com ela na creche.

Nessa faixa etária tem uma diferença, não é uma cobrança que você tem com a criança porque eles não mostram tudo que você está oferecendo. O retorno não é imediato, tem uma particularidade de como eles irão demonstrar ao longo do ano inteiro ou de um mês ou de um semestre. Quando você propõe algo para eles no dia-a-dia a reposta não é imediata, você vai vendo ao longo do tempo. Você tem três, quatro ou cinco bebês de seis meses, cada um vai demonstrar de um jeito.

Entrevista educadora "L"

A questão do tempo, percebida fortemente na coleta de dados evidencia alguns eixos de análise sobre a relação do tempo com a educação infantil. A organização temporal que a creche estabelece no atendimento às crianças é evidente tanto nas conversas com a coordenadora quanto a partir da leitura do Projeto Pedagógico. O termo rotina é designado na 
educação infantil para a organização do tempo. Permite aos adultos e às crianças localizaremse no tempo e no espaço, é o alicerce para construção dos vínculos e para a segurança da criança em um ambiente que não é o contexto familiar. O Referencial Curricular Nacional para a Educação Infantil (BRASIL, 1998) prevê o planejamento de rotinas bem estruturadas e a concebe como um instrumento de dinamismo e aprendizagem, facilitador das percepções infantis sobre o tempo e o espaço.

Alguns aspectos observados na creche pesquisada chamam a atenção com relação à rotina que desenvolvem. Primeiramente, o Projeto Político Pedagógico está em sintonia com a prática da instituição, ou seja, a tabela que consta neste documento (apresentada anteriormente neste trabalho) corresponde ao dia-a-dia das crianças e apesar de parecer óbvio, não é na medida em que temos comumente, pelas escolas de nosso país, Projetos Político Pedagógicos que não condizem com a realidade ou que simplesmente inexistem nas instituições infantis.

O tema sobre rotinas nas instituições de primeira infância é muito recorrente. Em geral, as escolas mantêm algum tipo de organização temporal para o atendimento, porém o desafio atual é como desenvolver as rotinas planejadas sem cair na armadilha da sociedade moderna, escrava do tempo e entendendo-o apenas cronologicamente. Tiramonti (2005), ao discorrer sobre a nova equação entre tempo e espaço escolares, fala de uma lógica temporal que não mais corresponde à realidade atual da escola. Uma escola antes transmissiva, que estabelecia a relação entre passado, presente e futuro de forma linear e tinha na figura do professor o transmissor da cultura, é colocada em xeque. O acesso à informação das sociedades contemporâneas promove uma nova relação das pessoas com o conhecimento devendo a escola se organizar não como um locus de transmissão, mas como foro de cultura (BRUNER, 1997).

Repensar os tempos para a primeira infância, em especial os bebês, é fundamental no sentido de contribuir para construção do currículo específico para essa faixa etária. Hoyuelos (2008b) questiona a falta de tempo para as crianças e ressalta a especificidade dos bebês:

As criaturas - sobretudo os bebês - não se movem pela medida do relógio. Seu tempo é o da ocasião, o da oportunidade dos instantes que o próprio crescimento proporciona em seu fluir, fluxo e trajetos vitais (p. 9, tradução nossa).

Quando se fala das rotinas na educação infantil, pensa-se essencialmente no tempo quantitativo, mas é imprescindível pensar que ao longo das mais diversas ações do cotidiano escolar o tempo subjetivo se faz presente. O mundo atual sugere a perda desse tempo interior, a pressa esfacela o tempo da experiência e a particularidade de cada um. Pensar em qualidade 
na educação da infância é pensar fundamentalmente como propiciamos aos pequenos essa relação com o tempo quantificado e como eles são respeitados dentro de seus tempos individuais.

O acompanhamento da rotina na creche pesquisada evidenciou um profundo respeito ao tempo dos bebês. A rotina garante pouco tempo de espera das crianças nas transições de atividade e, apesar de bem organizada, não é estanque. Em diversas situações as professoras mostram-se flexíveis em readequar suas intenções por fatores diversos. Além disso, apesar de haver uma rotina para o grupo, dentro de todas as ações o tempo de cada criança é respeitado.

Em cada visita à instituição a pesquisadora presenciou cenas que mostravam claramente quanto as crianças eram respeitadas em seus tempos. Um bom exemplo é o início da rotina do período da tarde. Entre $13 \mathrm{~h} 15$ e $15 \mathrm{~h} 30$ as crianças vivenciam sequencialmente os ateliês, o lanche, a escovação e o pátio. Os ateliês são momentos em que os grupos do Módulo I convivem em dois espaços interligados onde são propostas diferentes brincadeiras, além de atividades de artes plásticas. Os bebês do Grupo Azul não participam desse momento no início do ano por serem ainda muito pequenos. É um período estratégico, pois recebe as crianças que frequentam a creche somente no período da tarde e integra também aqueles que já despertaram do sono. É importante dizer que no período de descanso as crianças são acomodadas em colchões onde podem ou não dormir. Os que não desejam mais descansar seguem para os ateliês e os demais podem dormir até o horário desejado.

A rotina, apesar de bem estruturada não obriga todas as crianças a fazerem tudo ao mesmo tempo. Grande parte delas acordava entre $13 \mathrm{~h} 15$ e 14h15, mas as observações de campo mostraram muitas vezes crianças acordando durante o horário de lanche (14h15) ou mesmo no horário do pátio $(14 \mathrm{~h} 30$ - 15h30). Para que todas elas pudessem ser cuidadas com atenção as educadoras se dividiam nas tarefas: uma acompanhava o descanso e duas ficavam nos ateliês. No momento do lanche uma permanecia no ateliê guardando os materiais e organizando as mesas enquanto a outra ia com as crianças para que lavassemas mãos. $\mathrm{O}$ mesmo ocorre ao final do lanche, enquanto uma educadora permanece, a outra faz a escovação e segue para o pátio. Em geral, a estagiária que acompanha o grupo fica na sala de descanso até que todos acordem e providencia o lanche para eles posteriormente.

Em uma das visitas um acontecimento foi marcante. Era aniversário de uma das crianças do grupo e, como de costume, no lanche, há bolo e todos cantam 'Parabéns'. Nesse dia o aniversariante dormia além do tempo estabelecido para o lanche e as professoras anunciam ao grupo que iriam esperar um pouco mais para que o aniversariante viesse para sua comemoração. Nenhuma atitude precipitada de acordar a criança foi tomada, como também 
não foram desconsideradas as demais crianças do grupo. Então, uma das educadoras combinou com o grupo que naquele momento iriam tomar o leite e comer os biscoitos, para que mais tarde, quando o aniversariante acordasse, todos pudessem cantar 'Parabéns a você' e festejar.

Nos lanches, como em todos os outros momentos, as educadoras mostravam-se sempre tranquilas e carinhosas. Deixavam que cada um se alimentasse à sua maneira e respeitavam esse tempo particular. No grupo havia crianças em diferentes fases do desenvolvimento: uns já se alimentavam sozinhos e tomavam o leite na caneca; outros precisavam de ajuda para comer e tomavam o leite na mamadeira. Havia ainda aqueles que estavam no processo de transição entre a mamadeira e a caneca. Estes oscilavamm entre um e outro, mas eram convidados continuamente pelas educadoras a experimentar o uso da caneca com o auxílio do canudo. As professoras diziam que ao seu tempo todos passariam a tomar leite na caneca, mas era preciso respeitar cada um e que pouco a pouco eles descobririam e aprenderiam a utilizá-la.

Outras situações de respeito à individualidade também são frequentes, como nas atividades propostas que são sempre pensadas para o grupo todo, mas nem todos se envolvem da mesma forma ou no mesmo instante. As professoras mostravam-se muito tranquilas com relação a isso, costumavam convidar aqueles que estavam mais afastados, mas acima de tudo os respeitavam em suas escolhas, como revela o exemplo entre a educadora e Pedro:

Uma das educadoras propôs que as crianças sentassem em roda para que pudesse oferecer água e anunciar a próxima atividade do grupo. Aos poucos, todos se aproximaram dela e foram se acomodando em uma roda, exceto um menino, o Pedro. A professora o chama, ele olha, mas não vai até o grupo, então ela gentilmente diz: "Tudo bem Pedro, você não quer vir... você está ouvindo daí?". Pedro continua olhando atentamente para ela, parece realmente estar prestando atenção. Passam-se alguns minutos e a professora parece estar muito tranquila, continua auxiliando as crianças que estão ao seu redor, de vez em quando olha para Pedro, mas o deixa onde está. Mais tarde ele se aproxima e a professora comenta: "Que bom que você veio, quer água?".

Nota do diário de campo

Essa relação entre os tempos coletivos do grupo e os tempos individuais notada na creche está de acordo com que prevê Barbosa (2006):

Um dos objetivos centrais da temporalização da vida das crianças está relacionado à estruturação do tempo coletivo, mas deve-se fazer isso sem deixar de respeitar os tempos pessoais (BARBOSA, 2006, p. 151). 
A mesma autora enfatiza ainda a necessidade de estruturas flexíveis na educação infantil e a pesquisa revelou que apesar de as crianças serem muito respeitadas em seus tempos, a proposta da instituição em nenhum momento pode ser interpretada como uma concepção de liberdade extrema, sem limites. Muito pelo contrário, os limites eram bastante claros e todos eram respeitados em suas singularidades desde que não afetassem outro colega ou o grupo em geral. As professoras exerciam suas posturas enquanto adultos mediadores de processos de aprendizagem. O poder exercido por elas pode ser compreendido como desvelo - apontado por Noblit (1995). Esse desvelo garante a autonomia, o bem-estar de todos, as aprendizagens significativas e principalmente estabelece uma rede de relações éticas.

Conceber um planejamento flexível é respeitar os tempos das crianças e Dewey (1959) já falava dessa flexibilidade que garante a abertura para a experiência sem perder a solidez necessária. Gandini e Goldhaber (2002) falam que um planejamento flexível deve respeitar as ideias das crianças sem, contudo, segui-las cegamente. Devemos:

... estudá-las a fim de determinar a quais delas podemos dar seguimento, e como elas poderiam ser encorajadas, em um contexto de planejamento flexível e de um currículo flexível (...). O currículo é visto como decorrente das observações dos professores sobre as ideias e os interesses das crianças, mas também é elaborado conforme o que os professores pensam que poderá contribuir para o crescimento delas (p. 154).

A relação com o tempo na instituição pode ser apontada em mais dois aspectos observados. O primeiro deles refere-se ao trabalho com projetos. $\mathrm{Na}$ creche, todos os grupos desenvolvem projetos que são atividades pensadas dentro de um tema e visa aprendizagens específicas das crianças. Ao conversar com os educadores entende-se que cada projeto tem um tempo muito particular para acontecer. Ao contrário de conteúdos pré-programados com prazos a serem cumpridos, os projetos da creche surgem a partir de temas de interesse das crianças - no caso, por se tratar de crianças muito pequenas, os temas surgem a partir das observações atentas das educadoras sobre seu grupo. Além disso, os projetos não têm período estipulado e podem durar dias, meses ou até mesmo todo o ano letivo.

O segundo aspecto a ser mencionado relaciona-se à história de vida. Nessa relação do tempo sócio-histórico se faz a conexão entre o tempo passado e presente. As histórias de cada criança estão presentes na escola a partir do olhar atento e individual que as educadoras mantinham com esses pequenos. Além disso, os aniversários eram extremamente valorizados e o que são os aniversários senão a celebração do tempo? Todos os grupos tinham em suas salas um grande espaço dedicado aos aniversários. Em geral, eram grandes painéis montados pelos educadores, mas com contribuições das crianças que continham uma foto da criança e 
seu nome. Todos os dias, as crianças aniversariantes da escola poderiam solicitar junto às cozinheiras um cardápio especial com algum alimento que apreciassem de acordo com as regras nutricionais da instituição. Além disso, a equipe da cozinha preparava um pequeno bolo para cada criança cantar os parabéns com seu grupo. Havia ainda, na entrada da creche, um painel coletivo onde eram afixadas as fotos de todos os aniversariantes do mês. Durante aquele mês as fotos ficavam ali para que todos da creche, incluindo os visitantes, pudessem acompanhar o aniversário de cada um.

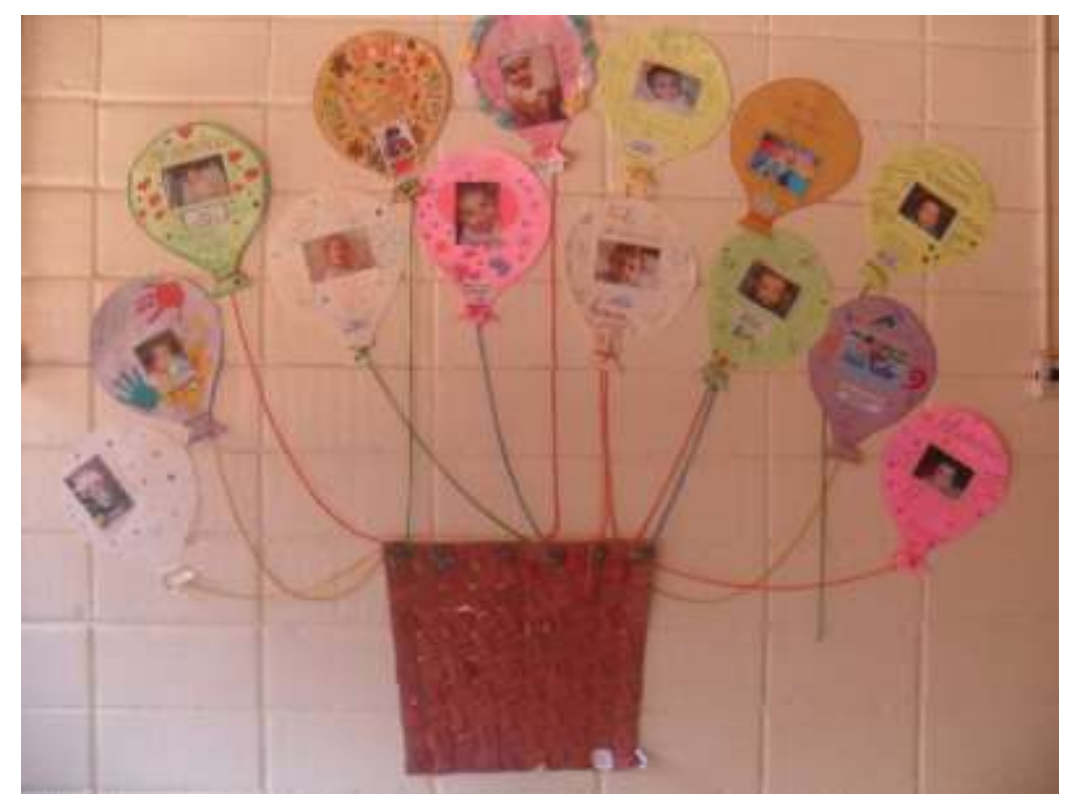

Figura 14 - Painel dos aniversários - Grupo Azul

Esse tempo histórico também é particularmente valorizado através da importância que a instituição e todos aqueles que dela fazem parte atribuem à história da creche. Por diversas vezes a pesquisadora ouviu os educadores falarem da conquista dessa creche, do trabalho de qualidade que conseguem realizar e da luta que travam em favor de maior reconhecimento profissional. É com muito carinho e orgulho que todos falam sobre a 'Casinha', espaço atualmente utilizado como sala ambiente dos bebês de 4 meses a 1 ano, mas que foi em outros tempos a única construção da creche e onde ela nasceu. Muito apropriados dessa história que pertence a todos, os educadores falam ainda do receio existente com relação ao futuro das creches universitárias. Por não terem obrigatoriedade legal em existir, eles temem seu desaparecimento.

A questão do tempo também é fundamental para a escuta das crianças, viver o tempo da infância, deixar-nos surpreender pelos feitos das crianças e interpretá-los é uma forma de compreendermos melhor a nós mesmos (HOYUELOS, 2008b). Pensar nos bebês é pensar que 
existe sempre outro em relação constante com ele e é preciso ocupar-se deles e atribuir significados a eles (ORTIZ e CARVALHO, 2012). Este contexto relacional é de fundamental importância, pois:

Na relação com o outro, a busca da própria identidade envolve um processo dialético de fusão e diferenciação: a cada momento, o indivíduo enfrenta o conflito entre a busca do familiar, que lhe dá segurança, com o qual se identifica, mas que às vezes o oprime, e a atração do desconhecido, o que pode provocar medo, mas abre novos caminhos. Nesse enfrentamento se dá o processo de individuação, a constituição do individuo como uma pessoa, a partir do ser humano genérico que foi gerado no momento da concepção (CARAVALHO; PEDROSA; ROSSETI-FERREIRA, 2012, p. 31).

A educadora "S" dá importância à relação interativa entre bebês e professores, pontua a sensibilidade necessária para o movimento de escuta e valoriza a interpretação das expressões:

Para se trabalhar com os bebês é preciso uma sensibilidade diferente com relação à escuta. Vivemos numa sociedade muito pautada no discurso e na linguagem oralizada, de palavras. O peso dessas palavras os bebês irão aprender comigo, mas por enquanto é outro tipo de escuta: você ouve um choro, um olhar, um sorriso. Isso é encantador para mim, saber que essa relação humana pode existir ainda porque as crianças um pouquinho maiores já estão muito pautadas nessa coisa de linguagem e discurso por palavras. Com bebês é outro tipo de relação, outro tipo de conversa porque a gente conversa de um jeito diferente. É uma conversa mais sincera porque o discurso vai se transformando: pensamos uma coisa, dizemos outra e fazemos outra ainda. Lá no Azul não é tanto assim porque tem essa conversa diferente, o olhar não consegue mentir. É importante ser sensível para esta conversa que é diferente, passamos a falar de forma diferente e também ser ouvida de uma maneira diferente. De fato, eles não entendem tudo que estamos dizendo, mas há outras coisas envolvidas nessa conversa que é diferente.

Entrevista educadora "S"

Compreender os bebês é pensar além do "o quê" ou "quando", mas pautar-se no "como" para compreendermos seus processos e suas potências (CARAVALHO; PEDROSA; ROSSETI-FERREIRA, 2012). A educadora "L" diz sobre a potência dos bebês e as diversas possibilidades de encontro e diálogo com essa faixa etária a partir das suas linguagens expressivas:

As crianças bem pequenas têm muito a nos ensinar. Você pode conversar com ela não só com palavras, mas com gestos, carinhos, na música, nas brincadeiras... você tem que estar feliz, inteira, aliás para tudo na vida! 
Entrevista educadora "L"

Escutar e interpretar as ações dos bebês depende também de um saber da prática do que é ser professora de bebês, ou seja, a apropriação do ofício da docência com crianças tão pequenas garante a qualidade no trabalho na medida em que os educadores fazem escolhas adequadas para a faixa etária. Defende-se que um trabalho qualitativo com bebês só pode ser assertivo quando estão envolvidos profissionais que conhecem aquela faixa etária e gostam de atuar com ela. Sobre este aspecto é interessante acompanhar o que as educadoras falam da atuação com bebês. Ressaltam o entendimento da prática e o gosto pela faixa etária:

Para se trabalhar com os bebês é preciso um entendimento dessa faixa etária e a possibilidade de desenvolvimento de um trabalho porque se a pessoa chega achando que não vai acontecer nada, que é só um trabalho mecânico porque são muito pequenos será um trabalho inútil. Você tem que gostar e isso faz diferença. Tem gente que diz que é só ter a técnica, mas eu acho que não. Tem que gostar da faixa etária porque tem essa coisa do afeto. É diferente de outra fase da vida como na universidade, por exemplo, que a pessoa consegue mesmo não tendo um grande afeto. Com bebês tem que ter afeto, senão não dá. Você tem que acreditar no trabalho e que é importante.

Entrevista educadora "M"

A formação específica para professores que atuam com bebês ainda é um desafio em nosso país e Pinazza (2004) ressalta que esse é um dos aspectos centrais para se pensar a qualidade da educação infantil, como também apontam os Indicadores da Qualidade para a Educação Infantil:

Um dos fatores que mais influem na qualidade da educação é a qualificação dos profissionais que trabalham com as crianças. Professoras bem formadas, com salários dignos, que contam com o apoio da direção, da coordenação pedagógica e dos demais profissionais - trabalhando em equipe, refletindo e procurando aprimorar constantemente suas práticas - são fundamentais na construção de instituições de educação infantil de qualidade (BRASIL, 2009, p. 54).

Os ganhos conquistados no âmbito legal ainda não ultrapassaram os limites do papel e a qualidade dos cursos de formação é questionável (ORTIZ; CARVALHO, 2012, PINAZZA; NEIRA, 2012). A distância entre teoria e prática apontada pelos autores consultados neste trabalho (PINAZZA, 2004, ORTIZ e CARVALHO, 2012, PINAZZA e NEIRA, 2012) também é percebida pelas educadoras, conforme ressalta a educadora "S". Ela 
aponta a desvalorização do trabalho com bebês e o acesso restrito a estudos sobre a faixa etária, ressaltando o quanto os saberes estão ainda muito pautados na prática, devido à carência de materiais produzidos que enriqueçam as discussões:

Gosto muito de trabalhar com os pequenos porque é um desafio mesmo dentro da pedagogia. Quando se fala de 0 a 3 , não se pensa no zero, fala-se dos quase 3 sempre, mesmo na Faculdade com os textos que são lidos, os relatos de experiência ou os livros, é sempre muito difícil ter pesquisas com os bem pequenos mesmo. Quando se fala do 0 a 3 pegam essa faixa toda, mas sempre se referem aos quase 3, aos 2 anos e meio, mas nunca do zero. Então por isso é bem desafiador porque você não tem onde buscar e na creche é interessante porque as fontes são as experiências das pessoas que estão aqui há mais tempo e que já passaram por este grupo mais de uma vez, ou seja, tem essa coisa empírica. A faixa etária dos bebês é o primeiro passo tão importante. Eu já consegui enxergar tantas coisas que mostramos para eles que é um pouco do que eles vão carregar, por isso traz responsabilidades e por isso temos que mostrar outros caminhos, mas ainda é um campo a ser explorado, não tem muita gente que pensa sobre isso.

Entrevista educadora "S"

$\mathrm{O}$ que os dados evidenciaram dizem respeito à postura qualitativa da prática da creche em relação aos bebês. Visto que uma prática de qualidade é a base para o trabalho com documentação pedagógica, mostraremos no próximo item como os registros e documentações evidenciam o olhar para os bebês e como se constituem elementos promotores da prática reflexiva e do planejamento da ação pedagógica.

\subsection{Uso dos registros}

A associação entre registros produzidos no âmbito da escola e sua função de constante reflexão sobre a prática foi discutida no campo teórico deste trabalho. Paige-Smith e Craft (2010), ao dizerem que a prática reflexiva vai do literal e imediato ao abstrato/conceitual e teórico, sustentam essa afirmação a partir da produção de documentações, não sendo elas apenas relatos de experiência, mas diálogo, interação e reflexão. Tanto as Diretrizes Curriculares Nacionais para a Educação Infantil como os Referenciais Curriculares Nacionais 
para a Educação Infantil também apontam os registros como instrumentos da prática, qualificando o olhar do professor e possibilitando a constante reflexão.

$\mathrm{Na}$ creche o espaço dos registros é bastante valorizado, associado à possibilidade de reflexão da prática e enfatizado no Projeto Político Pedagógico como um dos objetivos da creche:

Elaborar registros que deem visibilidade e oportunidade de reflexão sobre todos os âmbitos do trabalho desenvolvido.

Projeto Político Pedagógico da Creche, p. 8

É também apontado no mesmo documento como um dos planos da formação continuada:

Elaborar instrumentos para registros e planejar e registrar o trabalho pedagógico.

Projeto Político Pedagógico da Creche, p. 21

Sendo os registros uma preocupação central do Projeto Político Pedagógico da creche é importante pontuar o que a instituição entende por registros. No documento citado isso não é mencionado, porém, quando questionadas sobre as modalidades de registro que produzem, as educadoras elencam as ações que sistematizam o trabalho dia-a-dia, que compreende diversos documentos produzidos. Nas entrevistas elas explicitam em mais detalhes esses registros:

Temos o registro do planejamento com as atividades que a gente planeja, como foi, o que não deu para fazer, o que a gente tem que refazer. Às vezes é um pouco caótico este planejamento, vamos escrevendo, puxando flechas, então precisamos de um tempo para sentar e organizar a ação. Temos os registros das reuniões que a gente tem quinzenalmente com a coordenadora pedagógica e com a psicóloga. Temos um caderno de registro para isso. Temos também um caderno de registro, cada criança tem algumas páginas onde a gente vai registrando, os dois períodos têm acesso a esse caderno e assim conseguimos visualizar um pouco o que eles fazem de manhã, que é diferente da tarde e também podemos visitar o que fizemos à tarde.

$(\ldots)$

Outro registro que temos é o da rotina que fica lá onde tem informações sobre a alimentação do bebê, horário de sono... também são registros, servem mais para as famílias, mas servem para pautar a nossa organização de trabalho lá. 
Entrevista educadora "S"

No dia-a-dia temos tabelas que registramos o horário que a criança dormiu, acordou, como foi a alimentação (se comeu bem, se comeu pouco), os banhos e trocas. Esses registros das tabelas são trocados semanalmente e os pais têm acesso. Temos outro tipo de registro de cada criança de como ficou nos primeiros dias, como foi a adaptação. Qualquer educador pode pegar este caderno e anotar aquilo que acha interessante ao longo do semestre da criança. Eles nos ajudam na escrita do relatório individual e no plantão quando atendemos os pais... Temos também os registros do planejamento.

Entrevista educadora "L"

Temos um combinado de registrar uma vez por semana. Para este desenvolvimento individual temos um caderno com os nomes das crianças e um tempo para fazer isso. A gente sobe e cada uma vai colocando como a criança está se desenvolvendo, do que está gostando e isso vira um relatório individual depois que vai para os pais. A gente também aproveita esse caderno para os atendimentos individuais que são feitos duas vezes por semestre. A gente também faz o planejamento que é nosso das atividades, é mais pra gente mesmo. Vamos jogando tudo ali porque quanto mais elementos tivermos será melhor depois para o trabalho em si e para desenvolver o relatório de grupo. Tem também registros do grupo mesmo como a tabela de controle de alimentação e cuidados porque para esta faixa é importante.

Entrevista educadora "M"

Percebe-se que as educadoras associam a palavra registro às ações cotidianas que estruturam o trabalho e o planejamento, contudo, no decorrer de suas falas também se referem aos relatórios como registros:

Na reunião com os pais do final de ano entregamos para os pais um registro do ano todo que é o relatório de grupo. Contamos desde a primeira situação a partir dos registros, vamos contando tudo que aconteceu e compomos com esses registros para fazer este relatório final. Esses registros ajudam para o relatório e também para fazer a exposição porque é como uma linha do tempo...

Entrevista educadora "M"

Nota-se que são denominados registros todos os tipos de documentos que as professoras produzem no entendimento de documentos a partir da visão de Cardoso e Mauad 
(1997) como qualquer tipo de marca produzida pelo homem. Marcas materializadas por meio dos documentos que conforme a ampliação do termo constitui-se também monumento na direção de compreender a amplitude das relações que se pode estabelecer no contexto em que se encontra. A partir das percepções das educadoras temos elencados os seguintes tipos de registros/documentos:

- Planejamentos

- Registros de reuniões em equipe

- Caderno de registro das crianças individualmente, que tem grande foco no período de adaptação

- Tabela semanal de cuidados

- Relatório individual

- Relatório de grupo

Os registros/documentos produzidos pelas educadoras confundem-se entre aqueles de cunho organizacional e aqueles com potência reflexiva. Marques (2010), ao estudar os diferentes tipos de registros produzidos por professores de educação infantil, considera como registros escolares todos os documentos produzidos pela escola, o que constitui na visão de Mogarro (2006) o arquivo escolar como construção de memória coletiva e identidade educativa. No conjunto dos registros escolares são considerados tanto aqueles mais burocráticos e organizativos como os pedagógicos. Tendo em vista que este trabalho tem como interesse a análise dos documentos escolares como instrumentos de prática reflexiva, a pesquisa centrou-se na análise dos registros que possuem potência para a reflexão, pautandose exclusivamente nos planejamentos, no relatório de grupo e nas pastas-memória.

Antes de passarmos à analise desses documentos é importante mencionar que as educadoras concebem a prática de registrar como importantes para o trabalho cotidiano, as observações em campo também apontaram que a prática de produção de registros estava apropriada pela equipe da creche, que via sentido no ato de documentar e não o fazem apenas como o cumprimento de uma tarefa da creche instituída pela gestão.

Acredito que fazer registros é importante porque a gente se olha. A creche tem um percurso e cada educador tem seu percurso individual (...) Antes de eu entrar aqui eu fazia registros, mas não dessa forma (...) Todas as educadoras à sua maneira fazem esse planejamento recriado: umas fazem digital, outras no caderno, mas todas têm esse percurso que é de observar, anotar e poder rever a prática. 
Depois que você vê pronto é que compreende o percurso.

Entrevista educadora "M"

Ao falar da importância dos registros, a educadora M menciona o percurso de planejamento intitulado pela instituição de "planejamento recriado". Este planejamento é sustentado em pautas de observação a que nos dedicaremos mais adiante, pois a princípio é preciso descrever como o trabalho da creche está organizado.

Todos os agrupamentos, incluindo o berçário, desenvolvem Projetos de Trabalho e a partir deles estão presentes os registros pedagógicos que nos interessam especificamente nesta pesquisa (planejamentos, relatórios de grupo e pasta-memória). Em conversa com a coordenadora pedagógica ela explicita que os projetos são sempre organizados segundo os eixos de trabalho previstos do Referencial Curricular Nacional para a Educação Infantil.

A creche entende por trabalho com projetos:

... um dos principais veículos didáticos, uma iniciativa que reúne e articula diferentes ações, envolvendo pais, professores, funcionários e comunidade do entorno. Sua duração varia em consonância com a faixa etária, o interesse e o contexto no qual as crianças estão inseridas, possibilitando a resolução de problemas envolvendo ocorrências dentro e fora da sala de atividades ou da escola. O desenvolvimento dos projetos acontece em forma de espiral, em um ritmo orgânico, de acordo com o interesse, a curiosidade e o envolvimento das crianças. (...) cada grupo decide com os professores os assuntos a serem pesquisados no projeto de trabalho.

Projeto Político Pedagógico da Creche, p. 29

E especificamente sobre os projetos com os bebês:

Os Projetos de Trabalho que acontecem duas vezes na semana são propostas planejadas semanalmente com a finalidade de possibilitar que as crianças desfrutem de atividades pensadas a partir das observações realizadas durante a trama da rotina sobre algumas temáticas que mais lhes chamaram a atenção. O projeto de trabalho com crianças bem pequenas, especificamente com bebês, é construído dia-a-dia a partir das relações e interações que as crianças estabelecem entre si, com as educadoras, com os espaços (pátio, sala de sono, banheiro, refeitório, solário), com brinquedos e com outros adultos que circulam nos espaços da casinha, durante a rotina diária da Creche.

Relatório de Grupo Azul - 2012 
Para o início de um Projeto de Trabalho, as educadoras dedicam-se aos registros de observações do grupo sustentadas em pautas de observação. A primeira delas é de observação inicial dos interesses das crianças que servirão de base para o desenvolvimento do trabalho, descrita no Projeto Político Pedagógico:

Há uma pauta de observação na qual os professores registram os diversos interesses das crianças e a partir dessas dicas, os projetos são criados. (...) No percurso do projeto, as crianças têm a possibilidade de expressar seus conhecimentos, buscas, hipóteses, descobertas, vivências, emoções e sentimentos, utilizando várias linguagens...

Projeto Político Pedagógico da Creche, p. 29

Essa pauta inicial de observação é organizada em um documento composto por duas folhas nas quais estão explicitados eixos de observação dos educadores sobre as crianças em momentos específicos da rotina: roda de conversa, roda de história, brincadeiras no pátio, momentos informais, oficina de informação, ateliês, momentos das refeições, outros. As figuras 15 e 16 referem-se a essa pauta de observação:

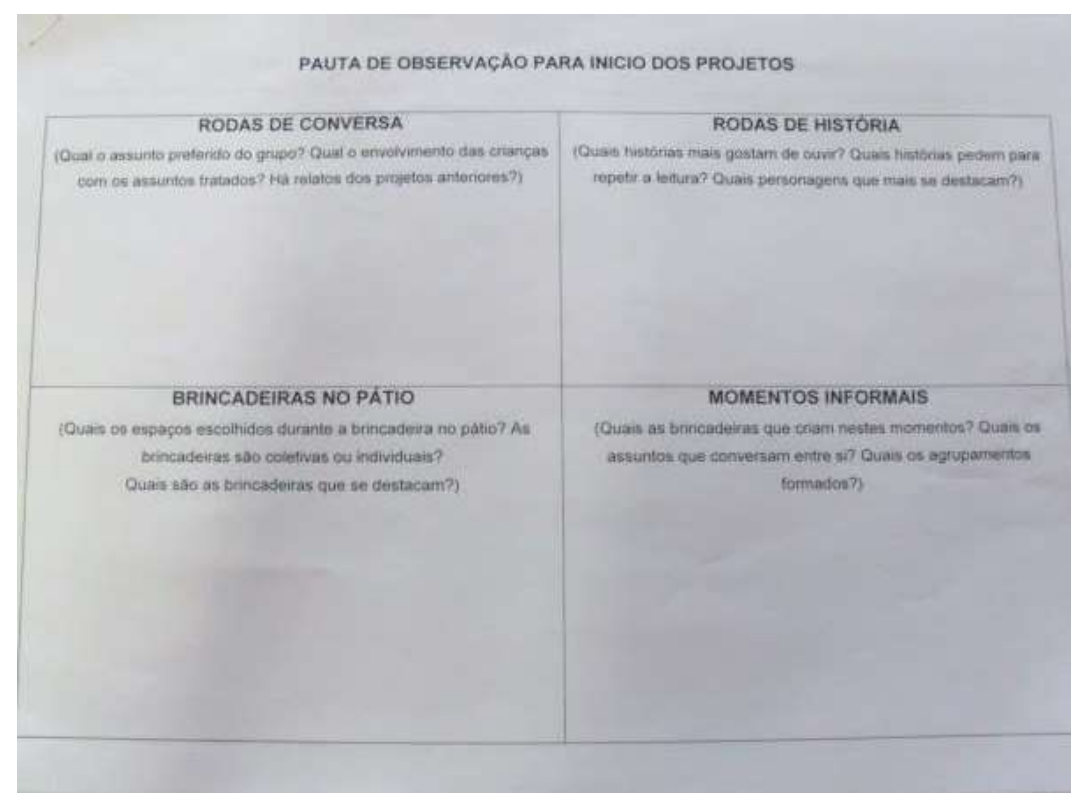

Figura 15 - Folha 1 da pauta de observação 


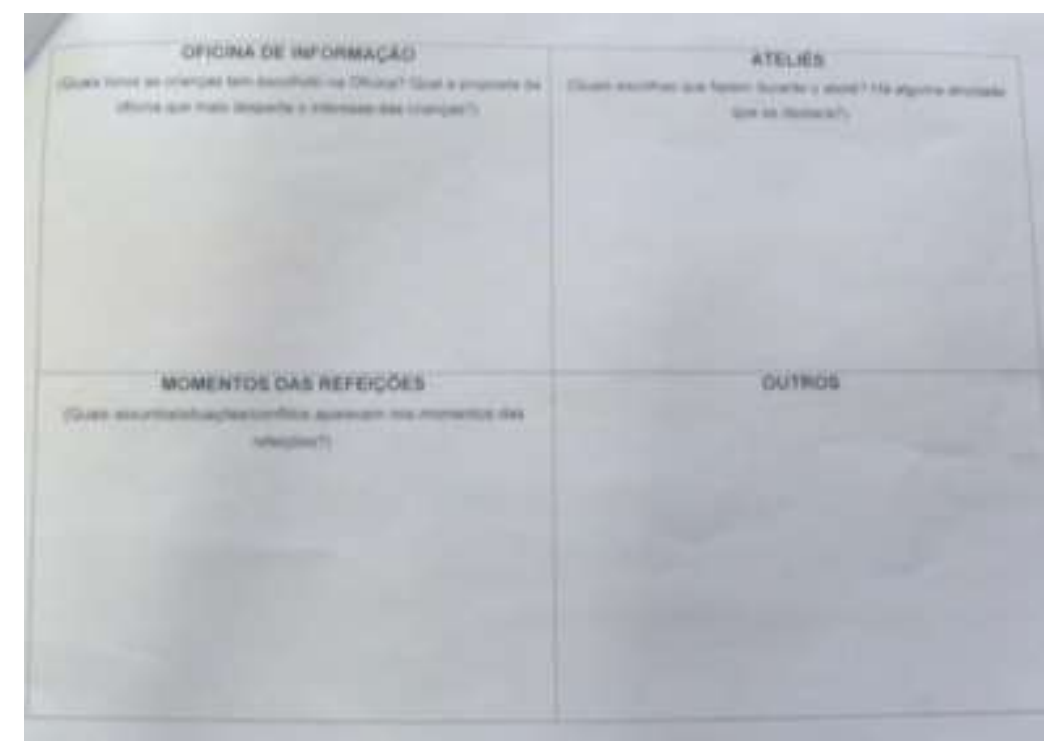

Figura 16 - Folha 2 da pauta de observação

A partir dessa pauta começam a se organizar os planejamentos dos projetos, compostos inicialmente por outras fichas que instrumentalizam a organização do trabalho:

- ficha com justificativas e objetivos do trabalho

- ficha com levantamentos prévios das crianças

- ficha de organização inicial do projeto (uma espécie de mapa feito pelas educadoras)

Sobre a produção desses registros iniciais do projeto do Grupo Azul de 2012, as pautas iniciais (figuras 15 e 16) não foram preenchidas bem como a ficha de justificativa e objetivos do trabalho (figura 17). O que se tem documentado são os levantamentos prévios (figura 18) e a organização inicial do projeto (figura 19).

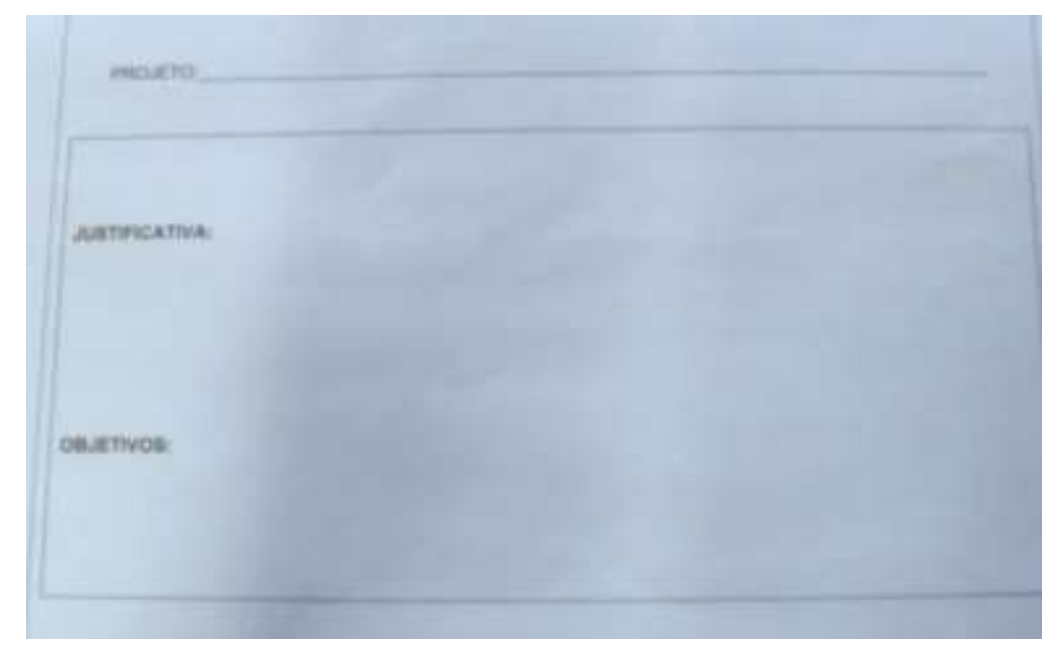

Figura 17 - Ficha de justificativa e objetivo 


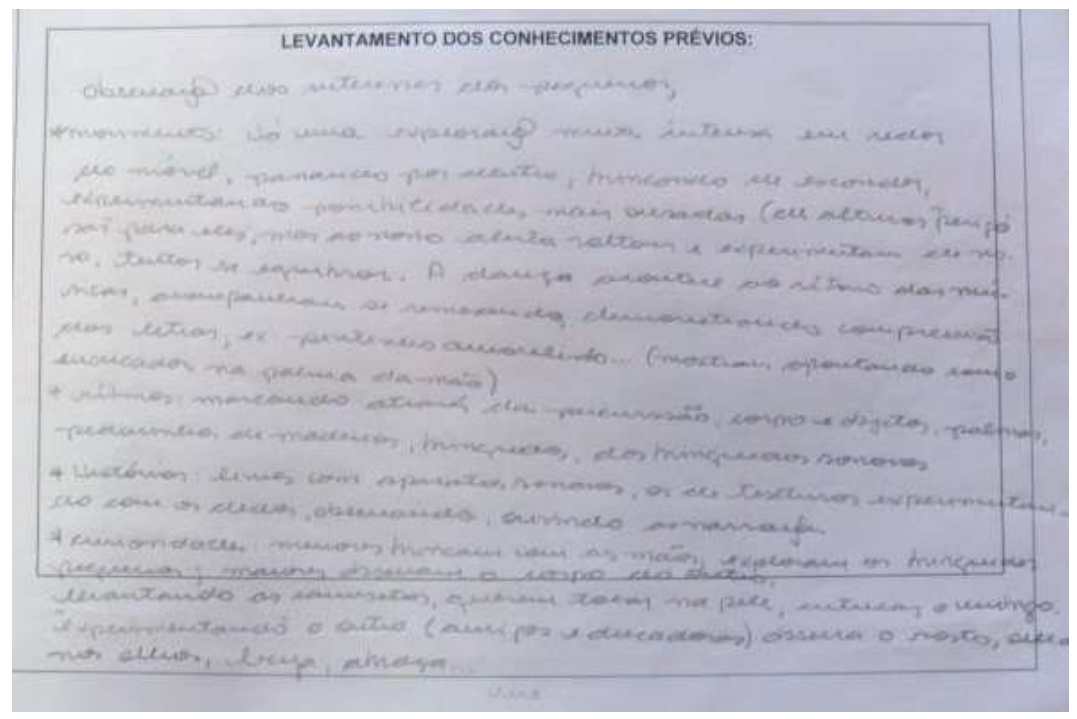

Figura 18 - Ficha dos levantamentos prévios

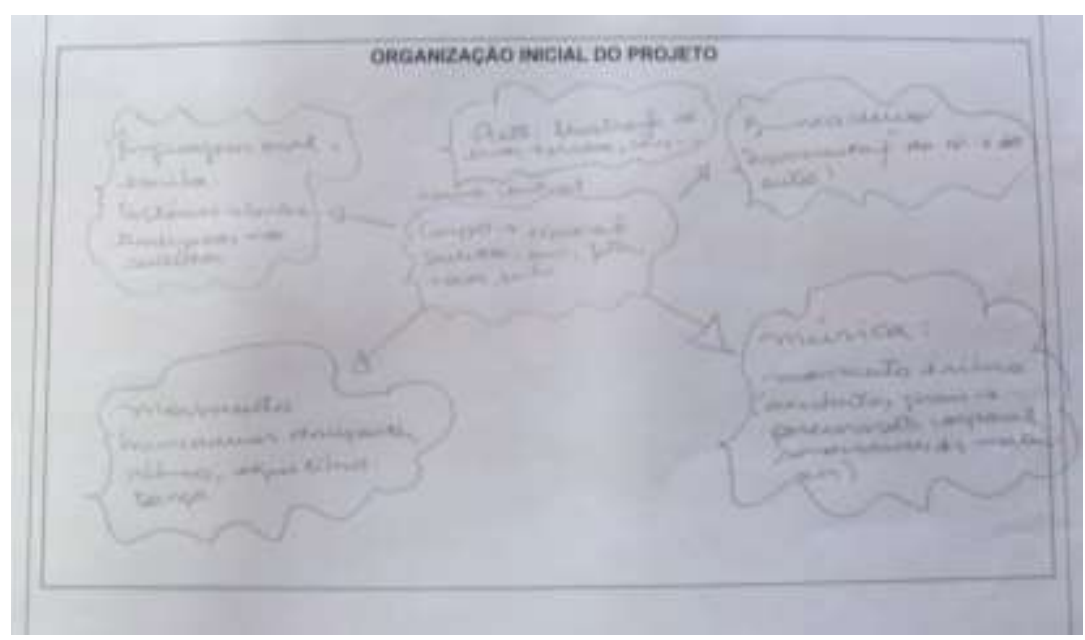

Figura 19 - Ficha da organização inicial do projeto

$\mathrm{Na}$ organização inicial e nos conhecimentos prévios do Grupo Azul de 2012 evidencia-se o interesse pelos ritmos, pelas histórias e as pesquisas de movimentos corporais, o que leva à seguinte organização do projeto:

Organização do Projeto

CORPO: exploração dos sentidos: ouvir, falar, tocar, sentir

ARTES: ilustração de livros, tecidos, cores

LINGUAGEM ORAL E ESCRITA: histórias contextualizadas nos sentidos MOVIMENTO: brincadeiras dançantes, ritmo, equilíbrio, dança

MÚSICA: movimento e ritmo (descobertas gerais e percussão corporal, sonoridade com diferentes materiais) 
BRINCADEIRAS: experimentação de si e do outro

Mapa da Organização do Projeto - Transcrição do Planejamento, folha 4

Além desses registros iniciais o percurso do trabalho é pautado pelas fichas de planejamento já descritas no item anterior deste trabalho. O Grupo Azul acompanhado ao longo de 2012 desenvolveu o projeto "Ritmos Coloridos"10, que parte do interesse do grupo pelas canções cantadas pelas educadoras ainda no período de adaptação. Uma dessas músicas especificamente trata de uma chuva de flores e estabelece relação com uma história em que a personagem do livro também é tomada por uma chuva de flores. Essa história passa a ser contada pelas educadoras no grupo diversas vezes e as ilustrações que trazem o contexto africano chamam a atenção do grupo. A história sempre contada pelas educadoras e intermediada pela canção da chuva de flores vai ao encontro das observações iniciais das crianças do interesse pelos movimentos e ritmos, além do encantamento do colorido das imagens. O foco do trabalho, conforme apontado no relatório de grupo, passa a ser os ritmos, os sons e as cores. Assim, as educadoras centram o trabalho em trazer músicas relacionadas aos interesses das crianças, apresentação e ampliação de instrumentos musicais e objetos sonoros, além da exploração das cores.

Como já incorporado no trabalho da creche, os planejamentos recriados buscam oferecer às professoras um instrumento para planejar as atividades do projeto a partir da flexibilidade nas ações previstas que são constantemente avaliadas para a elaboração da próxima proposta. Durante esta avaliação o termo dica é recorrente na fala das educadoras, incorporado na instituição e se refere à leitura das ações das crianças nas situações previamente pensadas pelos adultos e oferecidas ao grupo.

Depois de cada atividade que propomos registramos os movimentos e dicas das crianças. Essas dicas nos auxiliam a planejar outras atividades.

Entrevista educadora "L"

\footnotetext{
${ }^{10}$ Vide anexos sobre o projeto "Ritmos Coloridos".
} 
Ao longo do projeto desenvolvido no Grupo Azul os planejamentos foram compostos por doze fichas sequencialmente numeradas que apresentam o percurso do trabalho. Durante o projeto "Ritmos Coloridos" algumas situações apontam este olhar para as ações das crianças e o planejamento das educadoras segundo essas observações. O que nos interessou como foco de pesquisa foi investigar em quais medidas os registros com potência reflexiva de fato instrumentalizavam a prática das educadoras, ou seja, qual uso se fazia dos planejamentos, do relatório de grupo e da pasta-memória para a reflexão das educadoras no desenvolvimento das práticas com as crianças.

A análise do relatório de grupo aponta seis intervenções das educadoras a partir da observação das ações das crianças para o planejamento das propostas do projeto:

1. O interesse das crianças pelas fotos das famílias expostas na sala levam as educadoras a embalar o movimento das crianças no manuseio das fotos a partir de uma canção e relacionar uma das imagens do livro trabalhado no projeto da personagem no colo de sua mãe com as imagens das famílias das crianças:

Começamos a observar, então, o aumento do interesse das crianças pelas fotos do quadro das famílias. Uma exploração que era aparentemente indefinida passa a ser direcionada para encontrar a imagem da própria família e o reconhecimento dos pais. Algumas crianças, que começavam a se arriscar na produção de suas primeiras palavras, apontavam a "mamã", o "papá"... Será que teríamos uma música que pudesse nos embalar nesse momento de saudade?

\section{S.J}

Tô nos braços de mamãe

Pra ela me acarinhar

Apareça valentão

Para me tirar de lá

- Nos braços dela eu vou morar

\section{S.J}

Partindo de uma imagem do livro "Obax", em que a personagem abraça sua mãe, apresentamos essa música para as crianças. De início, algumas crianças choraram ao ouvi-la, porque pareciam ainda não lidar muito bem com a despedida da família e a palavra "mamãe" ainda despertava um sentimento de saudade quando pronunciada. Mas logo a música passou a representar um conforto, virou uma brincadeira que envolveu instrumentos e passos de dança. A saudade ficou colorida e mais bonita. 
2. O movimento de jogar areia sobre as placas coloridas de $\mathrm{EVA}^{11}$ para depois espalhar a areia e descobrir as cores presentes embaixo dela leva as educadoras a compor outros espaços no chão com papéis coloridos cobertos de areia para as crianças descobrirem as cores:

A atividade que propusemos em seguida, na verdade,
refletia uma brincadeira que as próprias crianças criaram e que
consistia em carregar a areia de várias formas (com as mãos, em
baldes, em pequenas panelas de brinquedo, em potes variados) e
espalhar em outro lugar.
Certa vez, espalharam a areia sobre uma placa de EVA
colorida e descobrir a cor por baixo da areia foi encantador para as
crianças. Assim, organizamos a atividade colocando papéis coloridos
no chão e cobrindo-os de areia para que as crianças pudessem descobrir
cores variadas e explorar ainda mais a areia. Para esse desenho corporal
sobre a areia as crianças usaram as mãos e os pés, gerando pegadas,
testaram as possibilidades de desenhar com alguns brinquedos e
recolheram gravetos do próprio espaço que funcionaram quase como lápis! E o Grupo Azul foi
ficando cada vez mais colorido...
a

3. O crescente interesse das crianças pelos instrumentos musicais e o fato da história contada ao grupo desde o início do projeto ser ambientada na África faz com que as educadoras tragam instrumentos musicais africanos para apresentar às crianças:

\begin{abstract}
musicais que fomos construindo para e com elas ao longo do ano inspirou-nos a apresentar aos pequenos um novo instrumento: a kalimba. Trata-se de outro instrumento africano (assim como o djembe), que dialoga, portanto, com a paisagem africana da história da "Obax" e com as estampas trazidas para a ambientação do espaço durante nossas atividades.
\end{abstract}

Relatório de Grupo Azul 2012

\footnotetext{
${ }^{11}$ Placas emborrachadas presentes no espaço do berçário para deixar o espaço mais adequado e acolhedor às crianças pequenas.
} 
4. O entendimento das professoras do interesse pelos coloridos das imagens pelas crianças e o interesse pelos instrumentos musicais faz com que as educadoras apresentem ao grupo imagens de artistas que trazem nas composições de suas obras os instrumentos africanos apresentados às crianças;

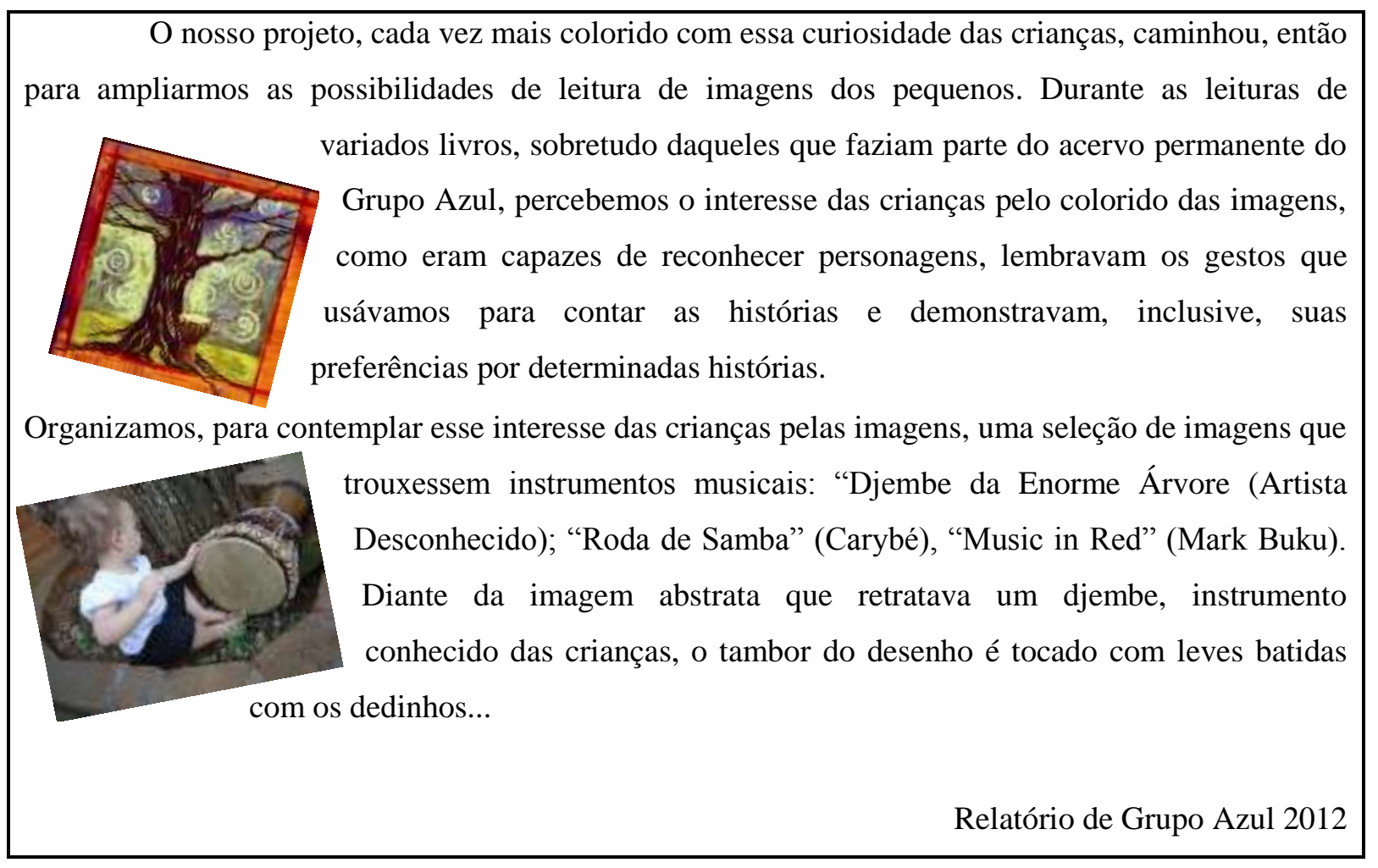

5. O interesse dos bebês em colocar na cabeça os tecidos utilizados para ambientar as propostas das atividades leva as educadoras à confecção de chapéus feitos com tecidos costurados em algumas estruturas de arame que ao serem torcidos criam formas variadas e possibilitam a experimentação das crianças em suas cabeças:

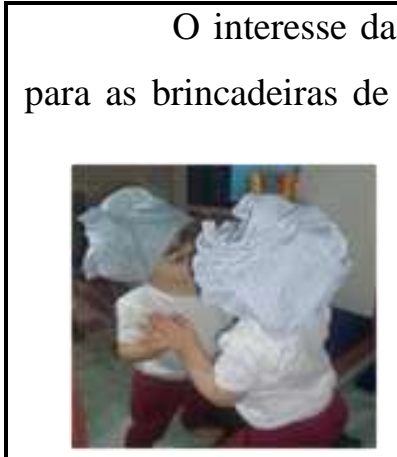

oferecidos, usavam os panos como enfeites na cabeça. O crescente interesse por colocar tecidos na cabeça, por chapéus e pelos próprios cabelos levaram-nos a trazer chapéus de cores e modelos variados. A resposta das crianças foi tão positiva que os chapéus integraram as atividades de várias tardes no Grupo Azul...

Relatório de Grupo Azul - 2012 
6. A interpretação das professoras do interesse das crianças pelo canto dos pássaros como outra situação que desperta a curiosidade pelos sons introduz no grupo uma canção e ações diárias de alimentação dos pássaros juntamente com as crianças:

As crianças sinalizaram também para a presença dos pássaros. Ouvimos juntos, ao longo do ano, o canto de vários pássaros, mais frequentemente, o canto dos sabiás. E para acompanhar o canto dos pássaros tínhamos também uma música:

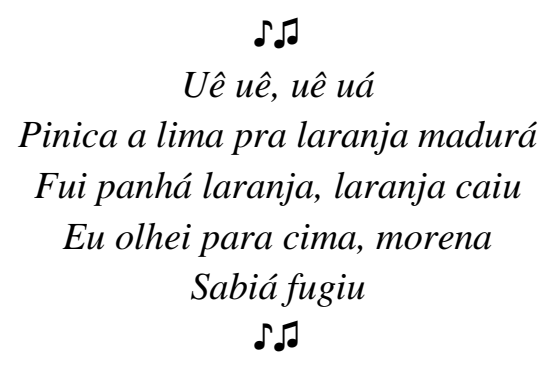

Uê uêe, uê uá

Pinica a lima pra laranja madurá

Fui panhá laranja, laranja caiu

Eu olhei para cima, morena

Sabiá fugiu

S.J

Em geral, quando os pássaros começavam a cantar, as crianças apontavam para o ouvido. O gesto parecia querer dizer: "prestem atenção, o pássaro está cantando". Porém muitos começaram a falar ao longo do segundo semestre e juntaram ao gesto de apontar o ouvido, a palavra "escuta" ou "piu piu" (referindose ao pássaro). As crianças gostavam muito de ouvir os pássaros e para garantir suas visitas, uma das atividades permanentes do Grupo Azul foi a alimentação dos pássaros, feita junto com as crianças sempre que possível.

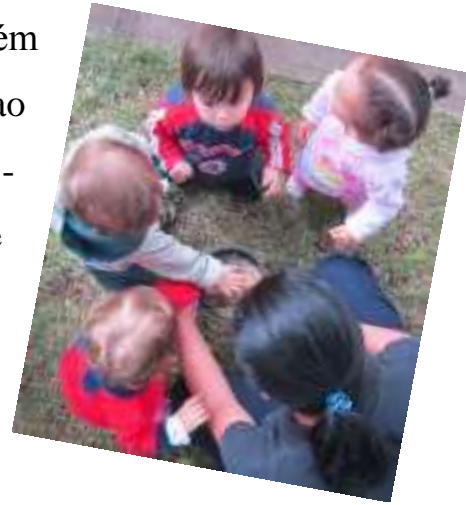

Relatório de Grupo Azul - 2012

As seis situações descritas acima que constam no relatório de grupo evidenciam a organização das propostas para as crianças segundo o observado. Na análise das fichas de planejamento as cinco primeiras situações aparecem ao longo dos registros, porém a última situação não consta nos registros de planejamento.

Situação 1:

Dica para recriar o planejamento: Família (apego)

Planejamento 2 
Situações 2 e 3:

Planejamento inicial: reapresentar os elementos da atividade anterior. Ênfase nas músicas "Battú" e "Guantanamera"; aproximações entre África e América - musicalidades.

Atividade com areia - desenho corporal na areia, montagem do espaço junto com as crianças.

Roda de histórias + instrumentos musicais (Novo instrumento: Kalimba)

Planejamento 6

Situação 4:

Dicas para recriar o planejamento: apresentar fichas com obras de artistas que apresentam pessoas e instrumentos, famílias e atrás das imagens, as músicas do interesse deles digitadas.

Obras: "Tocador de pífaro" de Édouard Manet e "Mãe camponesa" de David Alfaro Siqueiros.

Planejamento 3

Situação 5:

Dicas para recriar o planejamento: crianças se interessaram pelos tecidos amarrando-os na cabeça - ideia de oferecer chapéus no estilo de turcos ou turbantes.

Planejamento 9

O que se observa também nas fichas de planejamento é um movimento não linear das situações vividas como são apresentadas no relatório de grupo, ou seja, há certa desarticulação entre o processo vivenciado e descrito no planejamento com sua escrita formal nos moldes do relatório de grupo. Ao longo das doze fichas de planejamentos nem todas estão completas em todos os itens previstos: planejamento inicial, execução, registros, avaliação, dicas para recriar o planejamento, planejamento recriado. O que pode ser observado, inclusive, é a mistura na descrição desses itens, ou seja, não necessariamente onde está escrito planejamento recriado as professoras de fato evidenciam um novo planejamento, por vezes é apenas uma avaliação da situação vivida com as crianças. Esses dados nos levam à consideração de que ainda que os planejamentos estejam incorporados na prática das educadoras não necessariamente são utilizados como previstos. Além disso, os planejamentos evidenciam movimentos coletivos e não busca a análise processual individualmente das 
crianças. Esse fator é identificado pela creche como um ideal a ser alcançado, mas ainda muito difícil de ser conquistado na prática:

CP: No nosso caso, documentamos mais o coletivo, ainda não conseguimos documentar as crianças especificamente por conta da nossa realidade, nosso número de crianças. Alguns casos conseguimos, mas nem sempre, vocês mesmas já colocaram de como facilita quando tem alguém que ajuda a tirar as fotos

EM: De fato, este afastamento, este adulto que sai da cena para fotografar faz toda a diferença. Porque esse adulto interage pouco com as crianças e o adulto que está com as crianças tem que estar inteiro. Agora, esse formato individual do texto é bem bacana, mas essa professora ${ }^{12}$ deve trabalhar com grupinhos bem pequenos. Você consegue notar cada um dentro do coletivo, mesmo que não façamos dessa forma a gente sabe o percurso de cada um. Já falamos várias vezes sobre essa questão de individualizar, mas pra gente, pra nossa realidade é mais complicado ${ }^{13}$.

Reunião de Formação - 29 de outubro de 2012

Sobre o relatório de grupo é importante pontuar que se trata de um documento enviado às famílias ao final do ano e elaborado nos meses finais do ano letivo, ou seja, sua produção pretende compilar as experiências vividas ao longo dos planejamentos do projeto, porém não é feito processualmente. Esse fator ganha espaço nas reflexões da equipe do Grupo Azul quando durante a reunião de formação presenciada pela pesquisadora inicia-se uma discussão sobre a possibilidade de partes desse relatório serem compartilhadas com as famílias antes do final do ano.

$\mathrm{CP}:($...) aliás tem até uma coisa que fiquei pensando quando li o relatório de vocês: tem muita coisa que a gente escreve que eu não sei se temos que escrever no final do ano, se não teríamos que escrever no início do ano. Fiquei pensando, acho que a documentação permite isso, o olhar depois... eu já li muitos relatórios, mas pela primeira vez fui lendo este ano e pensando se não enviamos isso para os pais antes. Por mais que a gente diga na reunião de pais, no relatório vocês dizem tão claramente como se organizam os momentos, então pensei se não poderíamos elaborar um material

${ }^{12}$ Em sua fala a educadora refere-se à professora do texto trabalhado na reunião de formação

${ }^{13}$ Nos diálogos transcritos da reunião de formação acompanhada pela pesquisadora, são utilizadas as seguintes abreviações:

$\mathrm{CP}$ refere-se à coordenadora pedagógica

EM refere-se à educadora " $\mathrm{M}$ " envolvida na pesquisa

EL refere-se à educadora "L" também envolvida na pesquisa

EA refere-se à educadora "A", profissional não diretamente envolvida na pesquisa que atua com o mesmo agrupamento no período da manhã. 
que a gente pudesse entregar aos pais quando as crianças entram no berçário, no dia da reunião do berçário.

EA: É porque todo ano acaba escrevendo as mesmas coisas, não as mesmas coisas, mas coisas referentes aos mesmos assuntos e depois fica tão longe.

CP: É isso, fica tão longe, peguei o trecho de adaptação, fui lendo, fui lendo, e agora? Porque isso já é verbo do passado, já passou, eles já viveram... acho que é um texto que a gente vem pensando, vamos elaborando juntos, mas podemos entregar no início e no fim, já que temos só um relatório de grupo anual, poderíamos entregar as experiências com os projetos, assim como é com os outros grupos. Os outros grupos não têm esse detalhamento todo que a gente tem no Azul, eles contam uma introdução do movimento geral do grupo e depois vêm os projetos e outras experiências fora deles. Acho que poderíamos pensar nisso. Tem muito material bacana, coisas que vocês escrevem e escrevem com propriedade que se enviado no início do ano já dê conta.

EL: Se isso for no começo do ano irá fazer os pais entenderem a importância da adaptação que não precisa ser a longo, longo prazo.

EM: (...) Imagina um pai que vem completamente leigo, ele não sabe muito o que vai encontrar ali, por isso que eu comentei uma vez a surpresa de uma mãe quando ela veio e participou do momento de grupo. Ela ficou encantada. Ela não conseguia compreender o quanto o bebê pequeno é capaz, então eu acho que é melhor porque assim eles podem compreender como será o movimento do ano.

EL: É eu acho que no começo eles podem ler e ir acompanhando o que está acontecendo na prática.

CP: Vocês dizem tudo isso na reunião de pais, a estrutura da reunião de pais é toda essa, mas ao receberem um material concreto assim como recebem no final do ano, muito do que está ali eles poderiam acompanhar. Vocês falam da adaptação, falam do objeto de apego na reunião, mas lá é muita informação para um dia só. Acho que valeria a pena a gente pensar em um material, poderíamos pensar em uma diagramação que não fosse muito pesada, que fosse mais informativa, que pudesse vir com algumas fotos... eu fiquei pensando nisso. Aí no final do ano a gente conta as trajetórias dos projetos, as narrativas das crianças. Deixamos os pais a espera dessa experiência do que as crianças fizeram.

Reunião de Formação - 29 de outubro de 2012

Discorremos até aqui sobre os planejamentos e os relatórios de grupo, contudo há ainda outro registro produzido pela creche que nos interessa analisar do ponto de vista do foco dessa pesquisa, que busca investigar a relação entre prática reflexiva de professoras de creche a partir dos registros produzidos sobre o cotidiano das turmas de berçário.

Como já está evidente, o grande eixo de desenvolvimento do trabalho com as crianças na creche pesquisada baseia-se no trabalho com projetos. Os planejamentos das 
professoras centram-se no desenrolar de atividades dentro do tema do projeto, o relatório de grupo evidencia em grande parte o projeto do agrupamento e outro registro da instituição também tem como foco o projeto. Trata-se da pasta-memória. O movimento da creche revela a importância atribuída à confecção dela como sendo o mais importante registro de caráter documental da instituição. A produção dessa pasta está apropriada pelos educadores e é ação consolidada na creche, executada por todos os grupos e definida no Projeto Político Pedagógico:

Ao terminar um determinado projeto, alguns momentos são registrados em uma pasta-memória ou em um portfólio, contendo fotos, legendas, autores e coautores e ilustrações das crianças. Assim, além das lembranças, a creche tem registros concretos que, devidamente integrados à Oficina de Informação ${ }^{14}$ de que trataremos a seguir, compõem a documentação pedagógica e servem de leitura a todos e referência especialmente às professoras de outros grupos. A divulgação e o registro do trabalho possibilitam às crianças e à comunidade interna e externa evocarem os momentos significativos vividos. Desta forma, a identidade do grupo vai se constituindo, uma vez que todos se veem nesse processo dinâmico que integra a escrita e outras formas de comunicação à vida e aos objetivos dos grupos envolvidos nos trabalhos.

Projeto Político Pedagógico da Creche, p. 30

Ainda que incorporada ao trabalho da creche, a pasta-memória gera algumas discussões como o espaço para armazenamento, conforme aponta a educadora "M":

(...) essa é uma coisa que a gente ainda está no processo. Temos várias (pastas-memória) prontas, algumas para acabar, mas também para guardar todas não tem tanto espaço e essa é uma discussão na creche. Tem gente que não acha tão bacana.

Entrevista educadora "M"

A educadora "S" também fala da necessidade de organização do acervo produzido e reconhece na pasta-memória um importante registro da creche:

\footnotetext{
${ }^{14}$ Segundo o Projeto Político Pedagógico da creche a biblioteca nomeada "Oficina de Informação" tem como objetivo promover o acesso e apropriação da cultura pelas crianças, pais e professores/funcionários, bem como o desenvolvimento de competências necessárias a esse processo. Compreende um acervo de livros, vídeos, enciclopédias, revistas, livros técnicos, CDs, computadores, jogos em CD-ROM, além de documentos produzidos pelas crianças e adultos da creche (fotos, pastas-memória, livros etc.). Semanalmente os grupos, com exceção do Grupo Azul, dirigem-se a este espaço para consultas e empréstimos de materiais.
} 
Ainda não passei por este momento na creche, mas sei que existe o registro dos projetos. Cada grupo monta depois o que chamamos de 'pasta-memória' que é o registro do projeto desenvolvido naquele grupo, daquele ano. Estamos tentando organizar o acervo gigante que a creche já tem... eu não vivi esse processo de fazer e montar a pasta, saber como a gente organiza esses registros, mas com certeza é um tipo de documentação valiosa porque registra a passagem de cada criança em cada agrupamento desde a entrada dela na creche até a saída.

Entrevista educadora "S"

Além do problema de armazenamento das pastas-memória, a sua elaboração também é discutível. Costuma ser o último documento produzido pela creche ao final do ano letivo, buscando deixar registradas as etapas vivenciadas ao longo do percurso de um projeto, contudo o que a pesquisa em campo revelou e mesmo as conversas informais com as educadoras apontaram, é que nem sempre essas pastas são produzidas ao final do ano letivo. Muitas delas são deixadas para os primeiros meses do ano seguinte e no caso específico do grupo Azul de 2012 a mesma não foi elaborada, o que nos permite pensar qual o sentido dessa pasta.

Essa pasta como o nome evidencia busca guardar a memória da instituição e pode ser considerada conforme a proposta de Nora (1993): lugares de memória. No contexto do qual não há mais memória espontânea lhe consagramos lugares para que não sejam esquecidas. A pasta-memória seria, segundo as proposições desse autor, memória-arquivo, memória-dever e memória-distância, ou seja, fragmentos de memória compilados em um suporte para que o trabalho não seja esquecido.

Pensar na confecção das pastas-memória processualmente ao longo do ano letivo poderia ser uma alternativa para que a elaboração não ficasse para o ano seguinte, para que os registros ali contidos fossem construídos durante as vivências com o grupo e principalmente para que as crianças pudessem compartilhar esse processo e tivessem acesso a este material ao longo de sua produção, o que não acontece a partir do que foi observado durante a pesquisa de campo. Contudo a elaboração processual da pasta-memória recai sobre outra discussão que são as condições de tempo e espaço garantidas para sua elaboração.

A creche carece de tempo de formação e organização dos registros, ou seja, tempo garantido em serviço sem o atendimento às crianças. As seis horas diárias que as educadoras permanecem na creche preveem o atendimento às crianças, contudo a equipe gestora conseguiu organizar alguns horários formativos que são: 
- Reunião de Grupo: semanal das $12 \mathrm{~h} 15$ às $13 \mathrm{~h}$ - com as seis educadoras, em geral, uma semana com a coordenadora pedagógica e na outra semana com a psicóloga, na qual se discutem encaminhamentos para os planejamentos, organização dos espaços e agrupamentos, relatórios de grupo, reunião de pais, relações entre as crianças, entre crianças e professores e entre crianças e famílias, além de abordar aspectos mais particulares de cada criança.

- Reunião de módulo: 12 h30 às 13 h15 - não há uma frequência prevista, mas integra todos os educadores de cada módulo organizados por período (manhã e tarde) e é organizada no formato de grupo de estudo de textos relativos às demandas dos educadores. É comum haver uma documentação da reunião feita pelos educadores e arquivada em uma pasta.

- Momento de planejamento: semanal com 1h15 - destinado à reorganização dos planejamentos a partir da leitura das 'dicas' das crianças.

- Momento de registro: semanal com duração de trinta minutos - momento destinado ao registro de cada criança, organizado em um "caderno de registro".

Além das quatro situações descritas acima acontece ainda uma reunião de formação mensal e formações no início de cada semestre com cerca de 3 a 5 dias. Esses outros dois formatos preveem desde o início de cada ano letivo o não atendimento às crianças.

Apesar de os agrupamentos terem esses horários formativos, na prática eles nem sempre se concretizam e o que influi nessa dinâmica são, em geral, questões de organização da creche, pois considerando que eles acontecem durante o horário de atendimento às crianças, a creche conta com funcionários volantes, estagiários e o deslocamento de educadores de outros grupos para cobrirem os agrupamentos que cumprirão seus horários formativos. E ainda que se cumpram rigorosamente os horários previstos, estes ainda são escassos devido à demanda necessária. Um horário de trinta minutos (que muitas vezes na prática concretiza-se em 20 ou 15 minutos), por exemplo, para o momento de registro, não é suficiente, muitas vezes as educadoras fazem esses registros em outros períodos fora de seus horários de trabalho na creche ou o fazem na medida em que conseguem:

\footnotetext{
Nós temos seis horas de trabalho na creche, mas seis horas com as crianças. (...) Temos uma hora por semana (de planejamento), mas é pouco, então por conta disso a gente divide as crianças. Tem um número de horas que vale a produção do relatório... Outro registro que temos é o da rotina que fica lá onde tem informações sobre a alimentação do bebê, horário de sono... também são registros, servem
} 
mais para as famílias, mas servem para pautar a nossa organização de trabalho lá. Para este registro temos um horário para fazer que é mais complicado de cumprirmos, seriam quinze minutos por semana com dois educadores. É um horário que a gente tem um pouco mais de dificuldade, mas às vezes estamos lá, cuidando da sala do sono e aproveitamos para fazer o registro. Eu acho que a gente escreveria bem mais se isso estivesse mais dentro da rotina, esse registro é um pouco mais complicado, mas utilizamos para fazer o relatório individual.

Entrevista educadora "S"

A falta de condições estruturais para o desenvolvimento do trabalho é ponto de debate. Freitas (2009) afirma que não há como exigir uma escola reflexiva sem que haja reformas que garantam tempos e espaços de reflexão, ou seja, não está somente nas mãos do professor promover um trabalho qualitativo e reflexivo, há que se ter estrutura de trabalho para isso. Schenkel (2005), Warschauer (1993; 2001) e Paige-Smith (2010) também corroboram a mesma postura na defesa de condições para um trabalho reflexivo do educador e a contribuição desses autores nos leva à análise de que o trabalho da creche em grande medida não está legitimado por essas condições.

A análise de três registros fundamentais da creche (planejamentos, relatório de grupo e pasta-memória) nos levou também à discussão da potencialidade desses documentos enquanto documentações pedagógicas. Os dados revelam a familiaridade e apropriação de registros como instrumentos que estruturam o trabalho e tem por objetivo a constante reflexão da atuação com as crianças. No intuito de investigar em que medida esses registros potencializam uma possível prática de documentação pedagógica buscou-se analisar a compreensão da instituição e das educadoras sobre o tema.

No Projeto da creche o termo documentação pedagógica aparece no sentido de documento, dentro de uma perspectiva memorial, histórica e de visibilidade do trabalho a partir da elaboração das pastas-memória. Pode-se dizer da confusão entre os termos registro e documentação pedagógica, visto que no Projeto Político Pedagógico lhes são atribuídos o mesmo sentido:

Ao terminar um determinado projeto, alguns momentos são registrados em uma pasta-memória ou em um portfólio, contendo fotos, legendas, autores e coautores e ilustrações das crianças. Assim, além das lembranças, a creche tem registros concretos que, devidamente integrados à Oficina de Informação de que trataremos a seguir, compõem a documentação pedagógica e servem de leitura a 
todos e referência especialmente às professoras de outros grupos.

Projeto Político Pedagógico da Creche, p. 30, grifo nosso

Na reunião de formação acompanhada pela pesquisadora a coordenadora pedagógica utiliza o termo documentação ao se referir aos registros das educadoras, não fica clara a distinção entre registros/documentação e documentação pedagógica:

... pensamos se vocês tem alguma sequência de imagens que irão trazer ou que vocês tem e não irão trazer para a exposição, mas irá para o relatório... uma sequência em que vocês conseguiram acompanhar o passo a passo de uma criança ou de um pequenos grupo de criança, uma experiência que vocês tenham documentado e que isso valeu para vocês escreverem o relatório, tem alguma sequência marcante desse ano, do projeto que está de alguma forma registrada? Via foto ou via registro do planejamento, vocês conseguem lembrar-se do processo de vocês?

Fala da coordenadora pedagógica na Reunião de Formação - 29 de outubro de 2012, grifo nosso

Nas entrevistas com as educadoras o uso do termo registro como sinônimo de documentação pedagógica também aparece e pode ser justificado pelo recente trabalho da creche com relação à temática que ainda está sendo apropriada pela equipe:

Ainda não passei por este momento na creche, mas sei que existe o registro dos projetos. Cada grupo monta depois o que chamamos de 'pasta memória' que é o registro do projeto desenvolvido naquele grupo, daquele ano. Estamos tentando organizar o acervo gigante que a creche já tem... eu não vivi esse processo de fazer e montar a pasta, saber como a gente organiza esses registros, mas com certeza é um tipo de documentação valiosa porque registra a passagem de cada criança em cada agrupamento desde a entrada dela na creche até a saída. Eu acho que isso é documentação. Agora, essa coisa do que documentar e como documentar eu não sei teoricamente, conheci um pouco nas disciplinas da faculdade, mas aqui na creche, neste um ano que estou não tivemos nenhuma formação sobre isso, mas lembro que no começo do ano, durante a formação, foi um palestrante falar justamente disso, da importância desse registro. Acho que só pelo fato de já produzirmos as pastas memória já vamos ao encontro do reconhecimento da importância dessa documentação.

Entrevista educadora "S"

Acho que documentação pedagógica é tudo o que a gente faz, são os documentos que temos do planejamento, as pastas-memória, as reuniões pedagógicas que temos com a coordenadora 
pedagógica ou com a psicóloga a cada quinze dias. Temos um caderno de registro para escrevermos o memorial que nos comunicamos com as meninas da manhã, além da conversa ou algo que acontece no período, as formações continuadas também são registradas, as pastas-memória que contam um pouco dos grupos de crianças, além dos relatórios de grupo e individual. Acho que tudo passa a ser um documento e as fotos que já falam por si.

Entrevista educadora "L"

Temos falado sobre documentação pedagógica. Não é um tema super desenvolvido, mas já temos falado sobre ele nos últimos dois anos. A coordenadora e a diretora vêm com essa ideia e a gente vai entendendo o quão importante é para a instituição porque vai dando vida às coisas e é importante para quem chega depois para entender o processo. O que você registra você sabe que aconteceu, então sabemos que é importante, mas também sabemos que existem outras formas de fazer e a gente tem que ampliar. Acho que quanto mais formos deixando essas marcas será interessante para a valorização dessa faixa etária, para ela aparecer mais, para o entendimento das pessoas que não conseguem saber o que é o trabalho com criança tão pequena.

Entrevista educadora "M"

A coordenadora pedagógica também aponta este campo desconhecido da documentação pedagógica que a creche vai construindo a partir de sua prática:

Sobre documentação temos pouquíssimos materiais de zero a três, pouquíssimos mesmo na literatura, seja no Brasil ou fora. Então, vamos tentando construir a partir do que a gente faz (...). Ao mesmo tempo em que tem pouco material tem muita gente querendo ouvir sobre, querendo entender como a gente faz no dia a dia.

Fala da coordenadora pedagógica na Reunião de Formação - 29 de outubro de 2012

Fica bastante claro que a creche entende os registros como documentação, que por sua vez também é sinônimo de documentação pedagógica. Os usos dos termos em si não configuram qualquer problema, mas a concepção da documentação pedagógica conforme defendida no campo teórico deste trabalho poderia contribuir para uma significação dos usos dos registros na creche.

O primeiro aspecto a ser ressaltado refere-se à relação entre a confecção de produtos e construção de processos. Dos três instrumentos de registro com potência reflexiva analisados (planejamentos, relatório de grupo e pasta-memória) dois deles estão a serviço de 
se constituírem produtos finais de um percurso. Tanto os relatórios de grupo quanto a confecção da pasta-memória são elaborados ao final do ano e não são utilizados como recursos de reflexão durante o processo. Especialmente a pasta-memória é elaborada sempre após a exposição de final de ano e é importante contextualizar do que se trata essa exposição.

Cada agrupamento em datas específicas organiza na entrada da creche e em uma das salas próxima à entrada elementos dos projetos vivenciados. Esses elementos são objetos, imagens, brinquedos, painéis que transformam o ambiente. Para essa exposição muitos dos registros e fotografias ali expostas são aproveitados para a confecção da pasta. O processo de sistematização das ações ao final do ano que envolve o relatório de grupo, a exposição, a pasta-memória e as reuniões de pais é chamado pela coordenadora pedagógica de "Atividades de culminância" ou "Momentos de culminância", ou seja, ações que encerram as atividades vividas e originam um produto que revela o percurso percorrido. Em conversas realizadas com a coordenadora pedagógica (não registradas em áudio) e na reunião de formação do dia 29 de outubro é recorrente em sua fala referir-se aos "Momentos de culminância":

Culmina tudo, né: o relatório, todo o processo que vocês viveram, a exposição que é a síntese de tudo que vocês viveram mais a reunião de pais, então você terão três momentos, podemos dizer três atividades de culminância dentro do Grupo Azul. São três momentos que envolvem uma documentação, envolve os registros que vocês fizeram sejam eles do dia-a-dia, do planejamento, mais do grupo ou mais individual, mas entramos em um ponto importante que é a documentação.

Fala da coordenadora pedagógica na Reunião de Formação - 29 de outubro de 2012

A creche atribui especial relevância aos momentos de culminância porque é a partir deles que as educadoras debruçarão seu olhar sobre o processo vivido com as crianças e reconhecem na sistematização do trabalho desses momentos de culminância o grande trabalho documentativo da instituição. Vale pensar na relação entre os momentos de culminância e a reflexão sobre a ação (SCHÖN, 2000) das educadoras, ou seja, quanto esses momentos organizados para a reunião de pais, elaboração do relatório, exposição e confecção da pastamemória conduzem o grupo docente a retomar as situações vividas e a refletir em parceria.

O que pode ser notado, contudo, não é uma reflexão sobre a ação no sentido de um processo investigativo (FULLAN e HARGREAVES, 2001) e sim uma sistematização do que foi feito, ou seja, os momentos de culminância ressaltam sobretudo produtos que buscam evidenciar o trabalho com as crianças e vão contra a proposta de Rinaldi (2012) e Davoli (2011), que entendem o uso dos registros no decorrer do trabalho realizado, não sendo apenas 
memória, mas instrumentos de reflexão. Os momentos de culminância configuram-se dessa forma como fragmentos informativos que desconsideram os processos das crianças e não se dedicam à esfera subjetiva de interpretação de significados processualmente (COVRI, 2001). Ainda que as documentações pedagógicas pressuponham uma forma documental, esta é constituída dos processos reflexivos (HOYUELOS, 2006), ou seja, a forma documental não é o mesmo que produto. Assim, ao mesmo tempo em que é fundamental que essas práticas venham ao conhecimento do olhar externo à creche por meio da exposição, pasta-memória e relatório de grupo, elas precisam crescentemente distanciar-se da lógica somente informativa para alcançar uma perspectiva de reflexão e percurso processual.

Como grande recurso para o trabalho em documentação pedagógica estão as fotografias e o uso delas na creche pesquisada leva-nos a outra reflexão. As imagens, em especial as fotografias, são bastante utilizadas pelos grupos de crianças mais novas:

A exposição do Azul fecha o nosso calendário de exposições da creche, foi uma exposição que a gente construiu pensando muito em como fazer porque este trabalho pedagógico é subjetivo, fica nas entrelinhas, mas vai se expressando através de uma foto. A gente percebe que os grupos de zero a três têm muita foto mesmo porque temos o processo, temos a experiência, mas o que a gente consegue documentar vem com a foto. Ela traduz muito essa experiência, não sei se vocês sentem dessa forma...

Fala da coordenadora pedagógica na Reunião de Formação - 29 de outubro de 2012

A coordenadora ressalta a qualidade das fotografias tiradas pelas educadoras do Grupo Azul:

Vamos vendo as imagens do grupo azul e é possível enxergar o olhar das educadoras. Isso é muito interessante no trabalho do berçário. Vocês conseguem captar nas fotografias do Azul (não é uma crítica aos outros grupos) muito da alegria, da expressão. É diferente de fotografar todo mundo sentado numa roda. São naturezas diferentes, aí está a delicadeza do processo. Eu vejo que vocês tentam captar essa delicadeza do dia-a-dia que é muito difícil.

Fala da coordenadora pedagógica na Reunião de Formação - 29 de outubro de 2012

Consideradas pela instituição como formas de registro é interessante acompanhar o uso que as educadoras fazem das fotografias:

Utilizamos muito as fotos e elas são bacanas nessa faixa etária porque as crianças ainda não falam, os grafismos são representados de forma mais simples. Às vezes algum percurso que está 
acontecendo, com as fotos você registra tudo dessa exploração das crianças, desde o começo do desenvolvimento e de como ele é transformado, tem que ser um bom observador para conseguir ver. (...) A foto é importante para isso porque ela fala depois.

Entrevista educadora "M"

As fotografias fazem parte de uma dinâmica necessária dos educadores. Em geral, quando planejamos alguma atividade do projeto, a gente pega a câmera e registra.

Entrevista educadora "S"

Entretanto, as próprias educadoras revelam as dificuldades do registro fotográfico, atribuído à falta de domínio da técnica, à falta de costume em fotografar, a dificuldade em sair do momento de interação com as crianças para fotografar a ação, além do espaço físico que abrange o atendimento aos bebês.

...a gente se mata para registrar. Temos que estar no contexto, sair para fotografar, vai e volta e é muito ruim. Eu tento sair para fazer, mas não sou muito boa fotógrafa.

Fala da educadora "M" na Reunião de Formação - 29 de outubro de 2012

É, essa questão do espaço é uma questão para nós, por exemplo, o nosso espaço do berçário é muito recortado, durante uma atividade se tiver uma criança dormindo já tira uma educadora do contexto, se uma vai tirar fotos também sai do contexto. É algo que teremos que parar para pensar... se uma tira as fotos, a outra tem que dar conta do andamento da experiências junto com as crianças. É mais difícil, mas vou percebendo o quanto vocês educadoras fazem de esforço para fotografar e registrar.

Fala da coordenadora pedagógica na Reunião de Formação - 29 de outubro de 2012

As educadoras da manhã levam a câmera quase sempre e fazem muitas imagens da rotina que muitas servem pra gente também. Elas têm um pouco mais de familiaridade com o registro fotográfico. Eu tenho um pouco mais de dificuldade, é um pouco meu isso porque até buscar a máquina eu perco o momento, então eu prefiro estar ali e fica mais difícil porque fica na minha memória, no meu registro escrito, mas eu tenho um pouco desta dificuldade. Eu penso 'puxa, que legal que está aqui', mas vou sair daqui para buscar a máquina? Não vou... essa é uma dinâmica da creche que eu estou me acostumando, penso que poderia ter fotografado isso, mas eu não consegui sair dali... 
Entrevista educadora "S"

$\mathrm{Na}$ fala acima da educadora "S" outro aspecto relevante para análise, também notado pela pesquisadora durante as observações em campo, é evidenciado: o uso do registro fotográfico restrito às situações do projeto de trabalho em desenvolvimento. Tanto a imersão em campo de 2011 quanto a de 2012 apontam que as educadoras costumam fazer uso do registro fotográfico mais usualmente nas situações planejadas de projeto, o que revela novamente a ligação do registro com os momentos de culminância. Tanto a exposição do final do ano quanto a escrita do relatório de grupo fazem uso do recurso imagético, o que não pode ser visto como um aspecto negativo, mas o contrário, o registro fotográfico de outras ações cotidianas que não envolvem situações de projeto poderia ser explorado e também se tornarem recursos de reflexão da prática, e isso muitas vezes não ocorre.

Em parte, essa realidade pode ser explicada pelo fato de a creche ter máquinas fotográficas de uso coletivo, guardadas na sala de orientação, espaço que as educadoras têm livre acesso para buscar sempre que desejado, mas como a educadora "S" aponta em sua fala, nem sempre é viável deixar a sala de aula e as crianças para buscar a máquina fotográfica, visto que pode prejudicar o atendimento ao grupo ou ocasionar a perda do momento a ser registrado. Para solucionar essa questão é comum as educadoras permanecerem com as crianças vivenciando a ação e em outro momento retomar o vivido através de registros escritos.

O uso das fotografias para as crianças faz parte do trabalho no Grupo Azul. Fotografias das famílias e das crianças estão expostas diariamente na sala e outras de situações específicas, em geral relacionadas às situações do projeto, também são impressas e levadas ao grupo.

...temos essa disposição das fotos e é muito legal, as crianças dão um retorno muito positivo quando se veem lá e se reconhecem ali. Temos as fotos das famílias que compõem o espaço deles e que eles vão se aproximando. Primeiro é algo que não reconhecem, depois reconhecem a mãe, depois se reconhecem e depois reconhecem os amigos. Nas atividades que fazemos com fotografias deles percebemos o quanto é importante para eles rever aquele momento apesar de serem bem pequenos.

Entrevista educadora "S" 
A educadora "S" ressalta ainda a presença não só das imagens fotográficas, mas também todo o campo imagético a que os bebês estão cotidianamente expostos. Ela enfatiza o enriquecimento do trabalho proporcionado pelo recurso da imagem e problematiza o tipo de imagem que em geral é destinada ao público infantil

Eles (os bebês) estão expostos a muitas coisas imagéticas na creche. Mesmo as imagens que não são fotográficas têm uma resposta super valiosa, por exemplo, quando eu levei o djembe, o instrumento, e outra vez levei uma imagem super abstrata de um djembe embaixo de uma árvore para ver o retorno deles e a primeira coisa que a Luana fez foi tocar o instrumento da imagem. Então, este reconhecimento que eles têm das imagens é por conta do contato do dia-a-dia que eles têm. Essa é uma perspectiva de entendê-los como pessoas, eles são pessoas, não tem o momento em que passam a ser, então eu sou bem assim mesmo, o que eu vejo e acho legal eu mostro. Não existe essa coisa do infantil, do 'para bebê', sempre alguma coisa irá causar, tem muito menos a ver com faixa etária e sim com possibilidades que podemos oferecer, por isso a imagem está sempre presente, não só a fotográfica, mas as imagens de maneira geral.

Entrevista educadora "S"

Ainda que as fotografias possam ser utilizadas pontualmente como recurso de leitura dos gestos das crianças, as educadoras lançam mão delas de forma mais frequente e sistemática ao final dos trabalhos, com a montagem da exposição e da pasta-memória, o que novamente aponta o trabalho voltado aos momentos de culminância como produtos finais.

...temos um olhar mais atento para essa foto quando vamos finalizar com a exposição. Cada atividade que foi desenvolvida será ressaltada com as fotos, procuramos mostrar a sequência das ações, como ela foi elaborada e modificada. Então temos que dar uma boa olhada porque a gente vai tirando, tirando... A gente dá uma boa enxugada, vê o que é interessante e manda para a impressão. Depois da exposição essas fotos vão para a pasta-memória...

Entrevista educadora "M"

A exposição é importante, eu não vivi ainda, mas acho que é na exposição que nós teremos um pouco mais de tempo para rever de fato as fotos, se quisermos mostrar as fotos tocando os instrumentos, iremos lá procurar as fotos que tem as crianças tocando. A fotografia é isso, especialmente com a câmera digital porque você tira mil fotos e depois para selecionar isso é um outro trabalho que exige um tempo e na correria que a gente vive não dá para sentar lá e ver mesmo, olhar a fundo e ver que tirei uma foto de uma criança, mas na mesma imagem tem outra criança lá atrás fazendo outra coisa, 
então não dá para fazer isso. É na exposição o momento que a gente consegue dar uma olhada mais geral.

Entrevista educadora "S"

Nas duas falas acima é interessante apontar a relação entre a quantidade de fotografias tiradas e a impossibilidade de análise das mesmas, o que resulta em um amplo acervo não utilizado, pois é somente na montagem da exposição que a educadoras se detêm na análise das imagens. O processo de produzir as imagens para posteriormente vê-las com calma, analisá-las para leitura dos gestos das crianças e uso das imagens é vivenciado de forma contrária, ou seja, o recurso fotográfico está para ilustrar momentos dos quais as educadoras queiram representar e não para ser retomado para sua leitura:

A gente tira as fotos, descarrega e conversamos sobre uma foto muito boa, outra que um bebê está fazendo tal coisa, então quando descarregamos damos uma olhada geral e de acordo com o que planejamos e lembramos de algo que aconteceu, procuramos se temos o registro fotográfico deste momento, se encontramos, levamos para eles, na medida que o planejamento pede levamos para eles. Esse trabalho com os instrumentos é isso, levamos os instrumentos, eles estão explorando, estamos levando referências imagéticas diferentes dos instrumentos, mas também queremos mostrar a eles que eles são uma referência imagética pra gente, por isso temos o registro fotográfico deles interagindo com aquele instrumento que mostramos, é uma retomada. Mas acho que essa retomada geral será quando montarmos a exposição por conta do tempo.

Entrevista educadora "S"

Compreender o uso que as educadoras fazem das fotografias e a prática do registro por meio delas apontam dois aspectos possíveis:

- a imagem como ilustração dos momentos vividos dos projetos

- a imagem como recurso de prática reflexiva e escuta da criança

O primeiro tópico é claramente presente visto que converge com os momentos de culminância da creche. O segundo tópico ainda que haja um esforço e uma tentativa de ser realizado não o é satisfatoriamente, em grande parte atribuída pelas educadoras à falta de condições de tempo e espaço. A falta de tempo garantido para lapidação, análise e reflexão das imagens é real e influi diretamente no olhar qualitativo para o acervo de imagens 
fotográficas produzidas, contudo a grande quantidade de fotografias e a forma como é exposta é uma questão relevante na prática cotidiana das instituições de educação infantil. Se por um lado o recurso visual viabiliza a escuta da criança pequena e é ferramenta para a prática da documentação pedagógica, por outro ele ocasiona um excesso desnecessário que desqualifica o trabalho na medida em que produz uma poluição visual.

A exposição do final do ano vivida por todos os agrupamentos é um momento de evidenciar as ações das crianças, mas na percepção da pesquisadora (que pôde acompanhar as exposições de todos os grupos por estar no contexto da instituição ao longo do ano e acompanhar ainda mais de perto a exposição do Grupo Azul) muitas vezes o apelo imagético e fotográfico confundia o olhar do expectador que diante de tanta informação não consegue direcionar sua apreciação.

Nesse ponto valem as contribuições de Hoyuelos (2006), quando diz da contribuição das fotografias para as práticas documentativas que devem ser consideradas linguagem de escuta das crianças nas quais estão evidenciados seus processos de aprendizagem. $\mathrm{O}$ excesso de imagens e o que de fato elas podem comunicar proporciona o debate sobre a fotografia como linguagem em si e não apenas como ilustração do texto escrito. Seu caráter subjetivo também requer cuidado ao uso indiscriminado (MALAVASI e ZOCCATELLI, 2012).

Nos debates com o grupo de educadoras do Grupo Azul o olhar mais qualitativo para as imagens em relação aos demais grupos é evidenciado na fala da coordenadora pedagógica e em torno desse tema as educadoras começam um diálogo sobre as potencialidades da fotografia. Ainda que apostem no registro fotográfico como complementar ao texto escrito, elas passam a considerar seu uso como outra forma de apresentar as ações com as crianças a partir da incorporação de imagens nos relatórios.

CP: ...já tem alguns pedidos se não poderíamos colocar algumas fotos individuais nos relatórios individuais.

EA: Eu concordo porque a gente às vezes escreve muito para dizer e se tivesse uma imagem já estaria ali traduzido. Como não tem imagem a pessoa tem que imaginar como foi aquela cena e como ela vai imaginar? Tem que descrever os elementos, escrever, escrever...

CP: Vocês acham que a gente conseguiria fazer? Para este ano não dá, mas podemos pensar... EA: Não, não quero dar ideia porque senão tem gente que não vai gostar.

EM: Pelo tanto de fotos que temos tiradas certamente tem de todo mundo, acho que dá pra fazer sim... e usar algumas fotos coletivas é interessante até para os pequenos de quando eles começam a brincar juntos, isso é importante para os pais. Acho que temos material para isso. 
Reunião de formação do dia 29 de outubro

No diálogo acima as educadoras preocupam-se com os registros individuais de cada criança e em outro momento, a partir da discussão do texto de Azevedo e Sousa (2010) levado pela pesquisadora, elas novamente problematizam o uso que fazem dos registros coletivos e individuais.

CP: Ao longo do artigo elas trazem algumas sequências de fotos dos percursos de cada criança. No nosso caso, documentamos mais o coletivo, ainda não conseguimos documentar as crianças especificamente por conta da nossa realidade, nosso número de crianças. Alguns casos conseguimos, mas nem sempre..

EM: ...esse formato individual do texto é bem bacana, mas essa professora deve trabalhar com grupinhos bem pequenos. Você consegue notar cada um dentro do coletivo, mesmo que não façamos dessa forma a gente sabe o percurso de cada um. Já falamos várias vezes sobre essa questão de individualizar, mas pra gente, pra nossa realidade, é mais complicado.

Reunião de formação do dia 29 de outubro

As falas transcritas acima vão ao encontro das imagens fotográficas tiradas pelas educadoras e analisadas pela pesquisadora a partir do acesso ao banco de imagens do Grupo Azul. Pode-se perceber a grande maioria de imagens compostas por cenas coletivas, em geral situações de atividades dos projetos. Há uma quantidade menor de imagens mais individualizadas, mas nenhuma delas constitui sequências de ações de uma mesma criança no sentido do registro processual.

Um último aspecto a ser levantado a partir da prática dos registros na creche referese à comunicação que eles proporcionam quando organizados em documentações como a exposição, as pastas-memórias, os vídeos. Ainda que todos estes materiais produzidos tenham o fim maior de comunicar as famílias, a creche discute a possibilidade de uma divulgação mais ampla:

CP: Temos um item no nosso plano de trabalho que é levar nossas exposições para além, mas como fazer isso é outro ponto.

EM: Uma ideia é fazer virtual, fazer um blog. Poderia ter! E muita gente ia querer acessar.

CP: Realmente é uma grande ideia! Uma boa sugestão para levar nossas exposições... sempre 
pensamos em como fazer algo itinerante porque já é um sacrifício fazer aqui.

EM: Já sabemos um pouco de registro, para filmar a gente patina um pouco, mas temos outras coisas, tem outros lugares que fazem isso e é bem bacana.

Reunião de formação do dia 29 de outubro

A comunicação é aspecto bastante relevante na prática com documentação pedagógica e a incorporação dessa prática no trabalho da creche poderia estabelecer um campo fértil de diálogo que reconfigura a posição daquele que recebe a informação para interlocutor das documentações pedagógicas que lhe são apresentadas (BENZONI, 2001; MALAVASI e ZOCATELLI, 2012). A comunicação não é apenas recepção de informação, mas interação que reconstrói significados sobre o que está sendo comunicado, abre-se o caminho para os "possíveis" (PAIGE-SMITH e CRAFT, 2010). O que a creche agora compreende como comunicação para as famílias e comunidade como um todo pode ser ampliado para que se pense também nas comunicações possíveis dentro do contexto educativo, envolvendo a equipe educativa e as próprias crianças que participam muito pouco dos registros produzidos.

A maior participação das crianças é apontada pela coordenadora da creche como um aspecto que vem sendo refletido, ainda que não efetivado na prática. Ela fala de um protagonismo infantil possível por meio da escuta que as professoras do grupo Azul têm das crianças:

Eu até escrevi um material sobre isso, sobre a cultura da criança e a cultura do adulto e o quanto a documentação permite isso. Quando todos estão iguais no processo, não só o poder do adulto nem só o protagonismo da criança. Esse protagonismo todo que evidenciamos, que damos visibilidade também só pode acontecer porque tem a mediação de vocês. Todas essas experiências que vocês contam só podem acontecer porque vocês tem um olhar e uma escuta para isso.

Fala da coordenadora pedagógica na Reunião de Formação - 29 de outubro de 2012

A escuta das crianças é ponto fundamental da prática com documentação pedagógica, a ética de um encontro, conforme denominaram Dahlberg, Moss e Pence (2003), que requer a suspensão dos saberes dos educadores para poder perceber as crianças (AZEVEDO e SOUZA, 2010). No âmbito dessa pesquisa nota-se o esforço pela escuta das crianças, como demonstra a fala da coordenadora pedagógica: 
Acho que hoje tem muita coisa que o Módulo I faz que precisamos dizer ao Módulo II, precisamos mostrar o nível de detalhamento, o refinamento que temos chegado. Todos aqui têm muito claro quais os princípios que regem nosso trabalho, então se ainda não chegamos no registro individual é porque a gente não tem estrutura.

Fala da coordenadora pedagógica na Reunião de Formação - 29 de outubro de 2012

No entanto, os planejamentos anteriormente analisados e mesmo as observações em campo demonstram que nem sempre o exercício da escuta é praticado satisfatoriamente. No desenvolvimento dos projetos o olhar volta-se exclusivamente ao coletivo e a escuta individual das ações dos bebês que acontecem essencialmente por meio de situações interativas (CARVALHO; PEDROSA; ROSSETI-FERREIRA, 2012) não acontecem. A escuta presente na prática das educadoras são ações pontuais de leitura e interpretação no desenvolvimento do projeto onde o protagonismo infantil aparece muito mais com pequenas contribuições ao trabalho das educadoras do que efetivamente escuta das crianças.

O que a documentação pedagógica poderia oferecer à creche seria potencializar as práticas qualitativas que elas têm com os bebês. A pesquisa indica para isso, porém novamente a discussão sobre as condições de trabalho necessárias recai como ponto fundamental. Garantir tempo significa não apenas legitimar o tempo de trabalho dos professores, muitas vezes clandestino, mas também reconhecer a documentação pedagógica como prática de estudo e aprofundamento que envolva toda a equipe educativa, o que é um desafio não apenas para a creche pesquisada, mas para a educação infantil em nosso país. 


\section{CONSIDERAÇÕES FINAIS}

Ao buscar responder algumas perguntas, uma pesquisa suscita outras questões e surgem novas abordagens. Reconhecer essa amplitude de um estudo significa saber restringir os eixos específicos a que ele se dedica e aprofundar a discussão dentro de um campo. $\mathrm{Na}$ ocasião do ingresso no mestrado o intuito era investigar a prática da documentação pedagógica em contextos de educação infantil e mais especificamente com grupos de crianças entre 0 a 2 anos, em que se previa que a documentação pedagógica utilizada a serviço dessa faixa etária poderia ser ferramenta para a escuta e compreensão das múltiplas linguagens das crianças, uma vez que são bem pequenas e dominam pouco a linguagem oral. Além disso, o real desconhecimento da potência que os bebês possuem é algo arraigado na sociedade e nas próprias instituições dedicadas à primeira infância, logo uma pesquisa com bebês poderia contribuir para a mudança desse panorama.

O que se compreendeu ao longo da pesquisa, no entanto, foi que o estudo não era amplo o suficiente para dar conta de duas questões centrais que ele trazia à tona: a prática reflexiva de professoras de berçário por meio de seus registros e documentações da prática, e a escuta dos bebês. Ficou claro que o percurso da pesquisa centrou-se no âmbito das professoras e não tanto dos bebês, ainda que eles estejam presentes de muitas formas ao longo do percurso. Se, por um lado, a presença dos bebês dá vida ao estudo, por outro se reconhecem os limites da pesquisa em não aprofundar a escuta das crianças bem pequenas e suas interações, tema de grande relevância e que oferece muitas possibilidades para estudos futuros.

Tendo como eixo de análise a prática educativa das professoras de berçário a pesquisa buscou responder três perguntas centrais. A primeira delas pretendeu analisar os registros produzidos e o lugar dos bebês nesses registros a partir da seguinte formulação: Como os registros periódicos evidenciam o olhar para os bebês?

O respeito aos tempos dos bebês, a adequação das ações e o profundo respeito que as educadoras têm para com eles revelaram um olhar qualitativo. Essa postura responsiva mostrou um entendimento da faixa etária bastante específico e considerado nas suas potências e necessidades, balizando uma prática educativa que interpõe constantemente as práticas de cuidado e educação. O reconhecimento dessa postura nos registros periódicos guiou-nos até o campo da História para a discussão entre produção de documentos e lugares de memória. Que os bebês aparecem nos registros analisados é fato, porém a forma como aparecem, centralizadas em ocasiões do desenvolvimento do Projeto do Grupo Azul que visam 
os chamados momentos de culminância (exposição do final do ano, relatórios e pastamemória), leva-nos à reflexão de que esses lugares efetivam outro lugar para infância ou são apenas lugares de memória? Pareceu-nos que a segunda proposição está mais de acordo com os dados analisados na medida em que o aparecimento dos bebês nos registros é para relembrar momentos vividos no âmbito do projeto e não tanto para dar-lhes voz, o que nos leva à segunda pergunta da pesquisa: Como os registros podem se transformar em documentações pedagógicas com vistas ao planejamento e à avaliação das práticas?

Ficou claro que os registros, nos moldes dos planejamentos recriados, atribuem um movimento de constante repensar a atuação com as crianças, contudo a elaboração de documentos e produtos estéticos não percorrem a trajetória com as crianças, atribuindo novos significados e constantes interpretações, dando maior importância aos processos e não tanto aos produtos e resultados. Transformar os registros em documentações pedagógicas requer, antes de tudo, um olhar para os processos de aprendizagem das crianças compartilhados pela equipe educativa e com as próprias crianças, evitando assim cair no paradoxo das documentações pedagógicas que ao invés de revelar podem esconder.

No lugar de efetivar um outro lugar para as crianças, quando essas documentações são levadas no sentido restrito da produção de resultados, afirmam um lugar de memória para a infância que de tão desconsiderada precisa dos espaços de memória em formas de exposição, fotografias, pasta-memória para existir. Passar a interpretar os processos e partilhálos continuamente na busca de novos significados é a proposta de um trabalho documentativo que incorpora também a própria natureza humana de estar sempre em processo de desenvolvimento.

Ao interpretar os processos a equipe educativa se coloca continuamente em um ciclo de planejamento e avaliação. Planejar e avaliar o percurso de trabalho com os bebês foi ação percebida pontualmente na prática das educadoras, contudo elas não o fazem regularmente, pois são detidas pelos momentos de culminância que, apesar de ter um foco de sistematização do trabalho e evidência das crianças, apenas são apresentados em lugares de produtos estéticos, pouco partilhados com os bebês e não realizados ao longo do processo do trabalho.

Centrar-se nos processos e (re)significar a prática a partir da interpretação constante é a base do trabalho em documentação pedagógica e nos leva à resposta da terceira pergunta da pesquisa (Como as documentações pedagógicas estão a serviço da prática reflexiva do professor?), que requer uma análise mais ampliada.

Os registros produzidos não se configuram documentações pedagógicas porque não são constituídos processualmente e estão a serviço da confecção de produtos. Reconfigurá-los 
a partir da ótica documentativa requer essencialmente tempos e espaços garantidos às professoras e legitimados na instituição.

A pesquisa evidencia a carência desses espaços e tempos que, quando existem, são privilegiados como lugares de produção de documentos e não de reflexão em parceria. A discussão de tempos e espaços no âmbito da educação infantil para o exercício da reflexão docente é necessária e imprescindível para assegurar práticas de melhor qualidade e professores amparados no exercício de sua profissão docente. A reconfiguração dos registros quando feitos, analisados e interpretados ao longo do processo que, quando transformados em produtos estéticos, se configurariam como documentações pedagógicas, poderiam ser suportes de reflexão em parceria que não é feita devido à carência de tempos e espaços para isso. Mesmo os momentos destinados à produção de registros ou os encontros com a coordenadora para discussão da prática não se efetivam com a periodicidade prevista, reconhecidos pelas educadoras como situações importantes para o trabalho, mas pouco garantidas no cotidiano docente.

O processo investigativo também nos levou à reflexão do uso das imagens na educação infantil. O crescente uso indiscriminado e a extensa produção de imagens afeta as escolas. Discutir a forma que a prática do registro fotográfico vem sendo manipulado com as crianças, em especial as bem pequenas, é necessário para desvendar quanto as imagens interferem nas práticas pedagógicas. Notou-se na pesquisa uma grande produção de fotografias, a maior parte delas centradas nas ações do Projeto do Grupo Azul. Tal evidência enfatiza um movimento vivido não apenas na creche pesquisada, mas nas instituições de educação infantil em geral.

É inevitável concordar que a popularização das câmeras fotográficas contribui positivamente nas práticas pedagógicas na medida em que abre a possibilidade de registrar as mais diversas situações (HOYUELOS, 2006). A atitude fotográfica também é construída conjuntamente com o discurso da educação infantil, que perde cada vez mais o caráter assistencialista e luta pela articulação do cuidar e educar como processos indissociáveis que consideram as necessidades dos cuidados para a criança pequena e também a valorizam como protagonista de sua história, potente desde que nasce e considerada em seus direitos. Ainda que tal discurso encontre dificuldades de se efetivar na prática cotidiana, as conquistas nessa etapa da educação vêm crescendo consideravelmente.

A mudança de concepção do que é a criança e a função da educação infantil influem decisivamente para o uso das fotografias nas instituições e passam a fazer parte do acervo de recursos de todas as escolas infantis. Ainda que a proporção de máquinas 
fotográficas possa ser maior ou menor em diferentes contextos, elas existem nas creches e pré-escolas e se antes tinham uso restrito ao registro de fatos pontuais, especialmente festas e eventos (muitos deles ligados às datas comemorativas), atualmente seu uso se dá também como instrumentos de trabalho do professor. Portanto é fundamental nos debruçarmos sobre o uso da câmera e da imagem no trabalho cotidiano com as crianças.

Em primeiro lugar vale dedicarmos especial atenção à compreensão que se tem das fotografias nas escolas, buscando entender se são consideradas meras ilustrações (a partir da possibilidade de representar determinadas ações) ou como linguagem comunicativa.

Em segundo lugar devemos colocar em constante reflexão a relação entre quantidade de imagens registradas e a qualidade com que são feitas. A excessiva produção de fotografias não corresponde necessariamente a imagens com boa qualidade, é preciso educar o olhar para uma produção consistente e não descontrolada e indiscriminada. Outro ponto relevante é pensar sobre o que se faz com tantas imagens coletadas. Se o computador possibilita a revolução documentária na medida em que proporciona o armazenamento e o agrupamento dos documentos das mais variadas formas, é preciso pensar sobre o destino de tantas imagens produzidas. Serão destinadas a virar arquivos mortos? Fotografamos tanto para criar lugares de memória para a infância que não é considerada em sua potência?

Sobre o excesso de imagens vale também a reflexão sobre a invasão que sofrem as crianças no dia-a-dia pela impossibilidade de expressarem o seu desejo de serem ou não fotografadas. Professores ainda que bem intencionados invadem de alguma forma as ações das crianças na tentativa de captar imagens e muitas delas, na grande maioria das vezes, sequer serão vistas pelas crianças. Ou seja, é um desrespeito uma produção em tamanha quantidade para não ser utilizada e apresentada às crianças, o que também foi notado ao longo da pesquisa quando em apenas um momento específico do trabalho as imagens das próprias crianças são levadas a elas, porém, a maior parte do material ou não foi utilizado ou foi trazido às crianças somente no momento da exposição de final de ano.

Outra problematização importante recai sobre a formação do educador infantil no que diz respeito ao uso da imagem. Que tipo de formação lhe foi oferecida para o trato com as fotografias? Quais suportes lhes são dados para olhar as imagens além e poder refletir sobre elas em parceria? As educadoras da pesquisa reconhecem a potência do registro fotográfico, embora também enfatizem a dificuldade de fazê-lo.

A fotografia cria atitudes pedagógicas e pensar como elas interferem nas práticas, revelam ou modificam concepções é de extrema importância para pensarmos a qualidade do trabalho com as crianças. Encarando a fotografia como um documento histórico (fruto de 
escolhas que revela um espaço e tempo específicos), acredita-se no seu potencial para revelar as concepções pedagógicas na medida em que é a base para elaboração das documentações pedagógicas na educação infantil. Ao pensarmos neste papel da fotografia estamos concordando com Kossoy (2002, 2004, 2005), Sontag (2006), Bourdieu (2004) e Freund (2004), quando falam da não neutralidade e das escolhas feitas. Em uma documentação pedagógica estão organizadas séries de imagens que revelam valores éticos e estéticos, concepções implícitas ou explícitas de criança, infância e educação infantil.

$\mathrm{Na}$ medida em que as fotografias são representações do real intermediadas pelo fotógrafo é certo que desvendar os processos de produção que o professor percorre para a concepção de uma imagem revela aquilo no que ele acredita, mais um motivo para determos maior atenção à qualidade das imagens e não à quantidade, já que as captações exacerbadas podem produzir conteúdos imagéticos com pouca profundidade e consistência. A produção de fotografia na educação infantil deve ser recurso de apoio ao professor reflexivo que saiba dosar o uso da máquina para não substituir a experiência vivida ao lado das crianças em imagens, já que não se pode atuar e registrar ao mesmo tempo.

Por fim vale a discussão em torno da condição documental das documentações pedagógicas. Todo aquele que estabelecer um diálogo com a documentação pedagógica produzida terá a sua frente aquilo que é fixo (a condição histórico-documental), mas também aquilo que é moldável que são as formas particulares com que cada receptor dialoga com o produto exposto. Ainda que o interlocutor possa transitar por ideias e compreensões mais amplas diante de uma documentação pedagógica, ao produzi-la assumimos quem somos e revelamos nossas posições.

Daí o caráter grandioso dessa prática pedagógica na educação infantil: ela é flexível na medida em que possibilita o diálogo, mas sua condição de documento que não é neutra contribui para a divulgação de uma concepção de infância. Essa possibilidade de intercomunicação que a documentação pedagógica estabelece é extremamente enriquecedora para que se reflita mais a respeito das práticas com crianças pequenas e passe a valorizar a educação infantil com maior respeito.

$\mathrm{Na}$ defesa da documentação pedagógica como locus do olhar qualificado para as crianças entende-se também que por meio dela temos um caminho possível para uma nova pedagogia para os bebês, uma pedagogia centrada na busca de significados:

$\mathrm{Na}$ verdade, acredito que a documentação é uma parte substanciosa do objetivo que sempre caracterizou nossa experiência: a busca pelo significado - encontrar o significado da escola, ou melhor, construir significação da escola como lugar que desempenha papel ativo na busca das crianças pelo 
significado e na própria busca por significado (e significados partilhados) (RINALDI, 2012, p. 121).

A documentação pedagógica pode ser um novo caminho para a educação com bebês, uma forma de garantir seu estatuto de protagonista na situação educativa, um instrumento de constante reflexão do trabalho docente que na busca dos significados partilha com as crianças e com a equipe educativa os significados da vida. 


\section{REFERÊNCIAS}

ÁRIES, Phlippe. História social da criança e da família. Rio de Janeiro: LTC, 2006.

AZEVEDO, Ana. Revelando a aprendizagem das crianças: a documentação pedagógica. Dissertação de Mestrado. Universidade do Minho/Pt. Minho, 2009.

AZEVEDO, Ana e SOUSA, Joana. A documentação pedagógica em contexto de creche: a partilha de poder. Cadernos de Educação de Infância (Revista da Associação de Profissionais de Educação de Infância), nº 91, 2010, 34-39.

BASSOTTO, Italo. Generi di documentazione nella letteratura pedagógica. In RED TERRITORIAL DE EDUCACIÓN INFANTIL DE CATALUÑA. Documentar la vida de los niños y las ninãs em la escuela. Barcelona: Ediciones Octaedro-Rosa Sensat, 2011.

BARBOSA, Maria Carmem. Por amor e por força: rotinas na educação infantil. Porto Alegre: Artmed, 2006.

BARBOSA, Maria Carmem. Especificidades da ação pedagógica com bebês. Anais do I seminário nacional: currículo em movimento - perspectivas atuais, Belo Horizonte, novembro de 2010 (disponível em www.portal.mec.gov.br/index.php?option=com_docman\&task / acesso em jan/2013)

BARBOSA, Maria Carmem e RICHTER, Sandra Regina Simonis. Direitos das crianças como estratégia para a educação das crianças pequenas. Trabalho apresentado na $34^{\mathrm{a}}$ Reunião Anual da ANPED. Natal, 2011. (disponível em:

http://34reuniao.anped.org.br/index.php?option=com content $\&$ view $=$ article $\& i d=106:$ trabalho s-gt07-educacao-de-criancas-de-0-a-6-anos\&catid=47:trabalhos\&Itemid=59 $\quad$ (acesso em jan/2013)

BARBOSA, Maria Carmem e FERNANDES, Susana Beatriz. Uma ferramenta para educar-se e educar de outro modo. In Revista Pátio Educação Infantil, número 30, jan-mar 2012.

BENZONI, Isabella. Documentare? Sì, grazie. Bergamo: Edizioni Junior, 2001.

BERGONZINI, Anna. Gli spazi e i tempi per la documentazione al nido e ala scuola dell'infanzia. In BALSAMO, Carmen. Dai fatti alle parole. Bologna: Edizioni Junior, 1998. 
BONDÍA, Jorge Larrosa. Nota sobre a experiência e o saber de experiência. Revista Brasileira de Educação, Jan/Fev/Mar/Abr, 2002, Nº 19.

BONDIOLI, Anna. O projeto pedagógico da creche e a sua avaliação. Campinas: Autores Asssociados, 2004.

BOURDIEU, Pierre. Un arte medio. Editora Gustavo Gilli: Barcelona, 2004.

BRASIL. Lei $n^{o}$ 9394, de 20 de dezembro de 1996. Estabelece as diretrizes e bases da educação nacional. Brasília, DF, 1996.

BRASIL, Ministério da Educação e do Desporto. Referencial Curricular Nacional para a Educação Infantil. Brasília: MEC/SEF, 1998.

BRASIL. Ministério da Educação. Secretaria de Educação Básica. Parâmetros Nacionais de Qualidade na Educação Infantil. Brasília, DF: MEC, SEB, 2006.

BRASIL, Ministério da Educação. Secretaria de Educação Básica. Indicadores da Qualidade na Educação Infantil. Brasília, DF: MEC, SEB, 2009.

BRASIL, Ministério da Educação e do Desporto. Diretrizes Curriculares Nacionais para a Educação Infantil. Brasília: MEC/CEB, 2010.

BRONFENBRENNER, Urie. A Ecologia do Desenvolvimento Humano: experimentos naturais e planejados. Porto Alegre: Artes Médicas, 1996.

BRUNER, Jerome. Realidade mental, mundos possíveis. Porto Alegre: Artes Médicas, 1997.

CAMPOS, Maria Malta, ROSEMBERG, Fúlvia e FERREIRA, Isabel M. Creches e préescolas no Brasil. São Paulo: Cortez; Fundação Carlos Chagas, 2001.

CAMPOS, Maria Malta e ROSEMBERG, Fúlvia. Critérios para um atendimento em creches que respeite os direitos fundamentais das crianças. $2^{\mathrm{a}}$ ed. Brasília, DF: MEC, SEB, 2009. 
CARDOSO, Ciro Flamarion e MAUAD, Ana Maria. História e imagem: os exemplos da fotografia e do cinema. In CARDOSO, Ciro Flamarion e VAINFAS, Ronaldo. Domínios da história: ensaio de teoria e metodologia. Rio de Janeiro: Campus, 1997.

CARDOSO, Sérgio. O olhar dos viajantes. In NOVAES, Adauto. O Olhar. São Paulo: Companhia das Letras, 1988.

CARVALHO, Ana M. A.; PEDROSA, Maria Isabel e ROSSETI-FERREIRA, Maria Clotilde. Aprendendo com a criança de zero a seis anos. São Paulo: Cortez, 2012.

COVRI, Claudia. La documentazione dei processi, In BENZONI, Isabella. Documentare? Si, grazie. Bergamo: Edizioni Junior, 2001.

DAVOLI, Mara. Documentar processos, recoger señales. In RED TERRITORIAL DE EDUCACIÓN INFANTIL DE CATALUÑA. Documentar la vida de los niños y las ninãs em la escuela. Barcelona: Ediciones Octaedro-Rosa Sensat, 2011.

DAHLBERG, Gunilla, MOSS, Peter e PENCE, Alan. Qualidade na educação da primeira infância: perspectivas pós-modernas. Porto Alegre: Artmed, 2003.

DEWEY, John. Democracia e Educação. Companhia Editora Nacional: São Paulo, 1936.

Como Pensamos. São Paulo: Companhia Editora Nacional, 1959.

Experiência e educação. Petrópolis: Vozes, 2011.

DOLCI, Mariano. Afinando la vista para captar los momentos. In RED TERRITORIAL DE EDUCACIÓN INFANTIL DE CATALUÑA. Documentar la vida de los niños y las ninãs em la escuela. Barcelona: Ediciones Octaedro-Rosa Sensat, 2011.

EDWARDS, Carolyn., GANDINI, Lella., FORMAN, George. As cem linguagens da criança. Porto Alegre: Artes Médicas, 1999.

FORTUNATI, Aldo. Experiência e memória: planejar e documentar as experiências: entre a memória do passado e a saudade do futuro. In A educação infantil como projeto da comunidade. Porto Alegre: Artmed, 2009.

FREINET, Célestin. A educação do trabalho. São Paulo: Martins Fontes, 1998. 
FREINET, Célestin. Para uma escola do povo. São Paulo: Martins Fontes, 2001.

FREIRE, Madalena. A paixão de conhecer o mundo. Rio de Janeiro: Paz e Terra, 1983.

FREIRE, Madalena. Observação, registro, reflexão: instrumentos metodológicos I. são Paulo: Espaço Pedagógico, 1996.

FREITAS, Luiz Carlos de (et. al.). Avalianção institucional: induzindo escolas reflexivas. In FREITAS, Luiz Carlos de (et. al.). Avaliação Educacional: caminhando pela contramão. Rio de Janeiro: Vozes, 2009.

FREUND, Gisele. La fotografía como documento social. Barcelona: Editora Gustavo Gilli, 2006.

FULLAN, Michael e HARGREAVES, Andy. Por que é que vale a pena lutar? O trabalho de equipa na escola. Porto: Editora Portor, 2001.

GANDINI, Lella e EDWARDS, Carolyn. Bambini: a Abordagem Italiana à Educação Infantil. Porto Alegre: Artmed, 2002.

GANDINI, Lella e GOLDHABER, Jeanne. Duas reflexões sobre a documentação. In Bambini: a Abordagem Italiana à Educação Infantil. Porto Alegre: Artmed, 2002.

GÓMEZ, Gregorio Rodríguez, FLORES, Javier Gil e JIMÉNEZ, Eduardo Garcia. Metodología de la Investigación Cualitativa. Ediciones Algibre, 1996.

GUIMARÃES, Daniela. Relações entre bebês e adultos na creche: o cuidado como ética. São Paulo: Cortez, 2011.

HADDAD, Lenira. A creche em busca de identidade. São Paulo: Lotola, 1991.

HADDAD, Lenira. Substituir ou compartilhar? O papel das instituições de educação infantil no contexto da sociedade contemporânea. In MACHADO, Maria Lucia de A. Encontros $e$ desencontros em Educação Infantil. São Paulo: Cortez, 2005. 
HELM, Judy. A importância da documentação. In HELM, Judy Harris e BENEKE, Sallee. $O$ poder dos projetos. Porta Alegre: Artmed, 2005.

HELM, Judy Harris e BENEKE, Sallee. O poder dos projetos. Porta Alegre: Artmed, 2005.

HOYUELOS, Alfredo. La ética en el pensamiento y obra pedagógica de Loris Malaguzzi. Barcelona: Octaedro-Rosa Sensat, 2004.

La estética en el pensamiento y obra pedagógica de Loris Malaguzzi. Barcelona: Octaedro-Rosa Sensat, 2006.

Documentación como narración y argumentación. Encontro com Alfredo Hoyuelos. Instituto Sidarta. São Paulo, 2008a.

Los tiempos de la infância. In Temps per Créixer, Universidad Autónoma de Barcelona: Barcelona, 2008b,15-30.

ITÁLIA, Comune di Parma, Assessorato Politiche per l'Infanzia - Settore Educativo e Sport. Insieme al Nido: carta del servizio. Graphital: Parma, 2007.

KISHIMOTO, Tizuko Morchida. A pré-escola em São Paulo. Doutorado em Educação. São Paulo: Faculdade de Educação da Universidade de São Paulo, 1986.

KINNEY, Linda e WHARTON, Pat. Tornando visível a aprendizagem das crianças. Porto Alegre: Artmed, 2009.

KOHAN, Walter O. Infância, estrangeiridade e ignorância. Belo Horizonte: Autêntica, 2007.

KOSSOY, Boris. Realidades e ficções na trama fotográfica. São Paulo: Ateliê Editorial, 2002.

Construção e desmontagem da informação fotográfica: teoria e história. Revista USP, São Paulo, n.62, p. 224-232, junho/agosto 2004.

. O relógio de Hiroshima: reflexões sobre os diálogos e silêncios das imagens. Revista Brasileira de História. São Paulo, Vol. 25. № 49, 2005. 
LANKSHEAR, Colin e KNOBEL, Michele. Pesquisa pedagógica: do projeto à implementação. Porto Alegre: Artmed, 2008.

LARROSA, Jorge. Notas sobre a experiência e o saber de experiência. In GERALDI, Corinta Maria Grisolia, RIOLFI, Claudia rosa e GARCIA, Maria de Fátima (orgs). Escola Viva. Campinas: Mercado de letras, 2004.

LE GOFF, Jacques. História e Memória. Lisboa: Edições 70, 2000.

MALAGUZZI, Loris. La educación infantil em Reggio Emilia. Barcelona: Octaedro-Rosa Sensat, 2001.

MALAVASI, Laura e ZOCCATELLI, Barbara. Documentare le progettualità. Bergamo: Edizioni Junior, 2012.

MARQUES, Amanda C. T. L. A construção de práticas de registro e documentação no cotidiano do trabalho pedagógico da educação infantil. Doutorado em Educação. São Paulo: Faculdade de Educação da Universidade de São Paulo, 2010.

MIGNOLA, Luciana. L'impostazione dela ricerca. In BENZONI, Isabella. Documentare? Sì, grazie. Bergamo: Edizioni Junior, 2001.

MOGARRO, Maria João. Arquivos e educação: a construção da memória educativa. In Sísifo. Revista de Ciências da Educação, 1, pp. 71-84. Consultado em julho/2013 em http://sisifo.fpce.ul.pt, 2006.

MONTI, Ines. La documentazione oltre la scuola. In BENZONI, Isabella. Documentare? Sì, grazie. Bergamo: Edizioni Junior, 2001.

MOSS, Peter. Prefácio. In PAIGE-SMITH, Alice e CRAFT, Anna. O desenvolvimento da prática reflexiva na educação infantil. Porto Alegre: Artmed, 2010.

NOBLIT, George W. Poder e desvelo na sala de aula. In Revista da Faculdade de Educação, São Paulo, v. 21, n. 2, p. 119-137, jul/dez, 1995.

NORA, Pierre. Entre memória e história: a problemática dos lugares. In Revista Projeto História, São Paulo, v. 10, p. 7-28, dez, 1993. 
OLIVEIRA, Zilma de Moraes Ramos de. Creches no sistema de ensino. In MACHADO, Maria Lucia de A (org.). Encontros e desencontros em educação infantil. São Paulo: Cortez, 2002.

OLIVEIRA, Zilma de Moraes Ramos de, et al. Creches: crianças, faz de conta e cia. Petrópolis: Vozes, 2011.

OLIVEIRA-FORMOSINHO, Julia. O desenvolvimento profissional das educadoras de infância: entre os saberes e os afetos, entre a sala e omundo. In OLIVEIRA-FORMOSINHO, Julia e KISHIMOTO, Tizuko Morchida. Formação em contexto: uma estratégia de integração. São Paulo: Pioneira/Thomson, 2002.

OLIVEIRA-FORMOSINHO, Julia. Pedagogia(s) da infância: reconstruindo uma práxis de participação. In OLIVEIRA-FORMOSINHO, Julia, KISHIMOTO, Tizuko Morchida e PINAZZA, Mônica Appezzato. Pedagogias da Infância. Porto Alegre: Artmed, 2007.

OLIVEIRA-FORMOSINHO, Julia. A escola vista pelas crianças. Porto: Porto Editora, 2008.

OLIVEIRA-FORMOSINHO, Julia (org.). O espaço e o tempo na Pedagogia-emParticipação. Porto: Porto Editora, 2011.

OLIVEIRA-FORMOSINHO, Julia e GAMBÔA, Rosário (orgs.). O trabalho de projeto na Pedagogia-em-Participação. Porto: Porto Editora, 2011.

OLIVEIRA-FORMOSINHO, Julia e FORMOSINHO, João. Perspectiva pedagógica da Associação Criança: Pedagogia-em-Participação. In KISHIMOTO, Tizuko Morchida e OLIVEIRA_FORMOSINHO, Júlia. Em busca da pedagogia da infância. Porto Alegre, Penso, 2013.

ORTIZ, Cisele e CARVALHO, Maria Teresa Venceslau de. Interações: ser professor de bebês - cuidar, educar e brincar uma única ação. São Paulo: Blucher, 2012.

PAIGE-SMITH, Alice e CRAFT, Anna. O desenvolvimento da prática reflexiva na educação infantil. Porto Alegre: Artmed, 2010.

PANTALENA, Eliane Sukerth. O ingresso da criança na creche e os vínculos iniciais. Mestrado em Educação. São Paulo: Faculdade de Educação da Universidade de São Paulo, 2010 . 
PARENTE, Maria Cristina Cristo. Formação em Contexto para o Desenvolvimento Profissional das Educadoras de Infância. In A Construção de Práticas Alternativas de Avaliação na Pedagogia da Infância. Braga, Instituto de Estudos da Criança da Universidade do Minho, 2004.

PERRENOUD, Philippe. A prática reflexiva no ofício do professor: profisionalização e razão pedagógica. Porto Alegre: Artmed, 2002.

PINAZZA, Mônica Appezzato. A pré-escola paulista à luz das ideias de Pestalozzi e Froebel: memória reconstituída a partir de periódicos oficiais. Doutorado em Educação. São Paulo: Faculdade de Educação da Universidade de São Paulo, 1997

PINAZZA, Mônica Appezzato. A educação infantil e suas especificidades. In GERALDI, Corinta Maria Grisolia, RIOLFI, Claudia rosa e GARCIA, Maria de Fátima (orgs). Escola Viva. Campinas: Mercado de letras, 2004.

PINAZZA, Mônica Appezzato. John Dewey: inspirações para uma pedagogia da infância. In OLIVEIRA-FORMOSINHO, Julia, KISHIMOTO, Tizuko Morchida e PINAZZA, Mônica Appezzato. Pedagogias da Infância. Porto Alegre: Artmed, 2007.

PINAZZA, Mônica Appezzato e NEIRA, Marcos Garcia. Formação de profissionais da educação infantil: desafio conjunto de investir na produção de saberes. São Paulo: Prefeitura do Município de São Bernardo do Campo / FEUSP, 2012.

PINAZZA, Mônica Appezzato. Desenvolvimento profissional em contexto: estudo de condições de formação e mudança. In KISHIMOTO, Tizuko Morchida e OLIVEIRA_FORMOSINHO, Júlia. Em busca da pedagogia da infância. Porto Alegre, Penso, 2013.

RINALDI, Carla. Diálogos com Reggio Emilia: escutar, investigar, aprender. São Paulo: Paz e Terra, 2012.

SÁ-CHAVES, Idália. Portfólios reflexivos também trazem gente dentro. Porto: Porto editora, 2005.

SCHENKEL, Maria Hermínia Benincá. Professor reflexivo: da teoria à prática. In SÁCHAVES, Idália (org). Os portfólios reflexivos (também) trazem gente dentro. Porto: Porto editora, 2005. 
SCHÖN, Donald A. Formar professores como profissionais reflexivos. In NÓVOA, Antonio. Os professores e sua formação. Lisboa: publicação D. Quixote, 1992.

. Educando o profissional reflexivo. Porto Alegre: Artmed, 2000.

SILVA, Carolina da Costa. O álbum parques infantis como objeto cultural. Dissertação de mestrado. Faculdade de Educação da Universidade de São Paulo, São Paulo, 2008.

SONTAG, Susan. Sobre la fotografía. Cidade do México: Alfaguara, 2006.

STAKE, Robert E. Investigación com estúdio de caso. Madrid: Ediciones Morata, 1999.

STAKE, Robert E. Pesquisa qualitativa: estudando como as coisas funcionam. Porto Alegre: Penso, 2011.

STENHOUSE, Lawrence. La investigación como base de la enseñanza. Cuarta edición. Madrid: Ediciones Morata, 1998.

TIRAMONTI, G. La escuela en la encrucijada del cambio epocal. In Educ. Soc., Campinas, vol. 26, n. 92, p. 889-910, Especial - Out. 2005 Disponível em http://www.cedes.unicamp.br (acesso em junho/2011).

TOMASELLI, Anna e ZOCCHI, Alessandra. Linee guida per i Servizi educativi ala prima infanzia: documentazione. Servizio Asili nido e Servizi complementari ala prima infanzia, Comuni di Firenze. Castello: Edizioni Junior, 2009.

WALSH, Daniel J. e GRAUE, M. Elizabeth. Investigação etnográfica com crianças: teorias, métodos e ética. Lisboa: Fundação Calouste Gulbenkian, 2003.

WARSCHAUER, Cecília. A roda e o registro: uma parceria entre professor, alunos $e$ conhecimento. Rio de Janeiro: Paz e Terra, 1993.

WARSCHAUER, Cecília. Rodas em rede: oportunidades formativas na escola e fora dela. Rio de Janeiro: Paz e Terra, 2001.

YIN, Robert K. Estudo de caso: planejamento e métodos. Porto Alegre: Bookman, 2005)

ZABALZA, Miguel A. Diários de aula: contributo para o estudo dos dilemas práticos dos professores. Porto: Porto editora, 1994. 
ZABALZA, Miguel A. Qualidade em educação infantil. Porto Alegre: Artmed, 1998.

ZABALZA, Miguel A. Diários de aula. Porto Alegre: Artmed, 2004.

ZEICHENER, Kenneth. A Formação reflexiva de professores: ideias e práticas. Lisboa: Educa, 1993. 
APÊNDICE A - Roteiro de entrevistas

1. Idade

2. Formação inicial

3. Tempo na instituição

4. Como chegou à creche

5. Tempo que já trabalhou com bebês

6. Por que escolheu trabalhar com os bebês

7. Como pensa as especificidades dos bebês

8. O que considera importante para o trabalho com bebês

9. Como planeja o trabalho dia a dia

10. Como é o grupo de crianças deste ano

11. Como foi o período de adaptação

12. Quais tipos de registros fazem

13. Qual a importância de fazer registros

14. O que fazem com esses registros

15. O que entende sobre documentação pedagógica

16. Como fazem (se fazem) documentação pedagógica 
APÊNDICE B - Transcrição das entrevistas com as alterações das educadoras

\section{$\underline{\text { Transcrição entrevista educadora " } L "(52 \text { anos })-20 / \text { set/2012 }}$}

\section{Qual sua formação inicial?}

Eu entrei na creche com o magistério, mas me formei já fazem dois anos em pedagogia por conta da nova lei. Na creche disseram que fazer pedagogia era para a carreira, para acrescentar e enriquecer minha formação.

\section{Há quanto tempo está aqui na creche e como chegou à creche?}

Estou na creche há vinte anos, sou a mais antiga do grupo. Cheguei aqui em 92, na época estava precisando de recreacionista e fiquei sabendo por amigos, então entreguei a documentação e em menos de um mês eu já estava empregada. Foi uma época em que a creche estava tendo muita rotatividade de educadores, entraram oito ou nove educadores de uma vez só.

\section{Muitos deles ainda estão aqui?}

Da minha época só tem eu e a Rosana que está no Grupo Verde da manhã.

Antes daqui, você trabalhava em outro lugar?

Antes daqui eu trabalhei em uma escola particular com criança de 5 anos. Fiquei um ano e depois passeio para o berçário.

\section{E aqui na creche sempre trabalhou com o berçário?}

Aqui na creche eu comecei no berçário, fiquei um tempo, em 98 peguei um grupo de crianças com 6 anos, fiquei só um ano, depois fui com criança de 4 anos e voltei ao módulo I, fiquei com crianças de 3 anos, depois de 2 anos e finalmente voltei ao berçário. Em vinte anos, eu fiquei 4 anos com crianças maiores e 16 anos com berçário.

\section{A escolha pelo berçário é sua?}

Algumas vezes eu optei por continuar no berçário, aqui na creche somos consultadas sobre qual grupo queremos ficar. Há muito atrás não era assim, você sabia o grupo que iria ficar no ano em uma reunião aberta. A creche foi discutindo e refletindo sobre isso e atualmente é assim: você é consultada sobre sua opção. Pode ter uma, duas ou até três opções pra escolher seu grupo e às vezes é contemplada.

\section{E por que você escolhe trabalhar com os bebês?}

Escolho os bebês porque me identifico bastante, eu tenho um olhar assim... bem mais cuidadoso, eu coloco uma lupa no dia a dia mesmo, do cuidar e educar que estão bem juntos. 
Ao mesmo tempo em que você tem um trabalho, um projeto, você também tem o outro olhar em situações de brincadeiras, nos tipos de materiais que você está utilizando. Tem que ter um certo cuidado de saber como você vai oferecer este material, em que espaço, como organizar o chão, a mesa ou o gramado.

\section{Como você pensa a especificidade dos bebês?}

Nessa faixa etária tem uma diferença, não é uma cobrança que você tem com a criança porque eles não mostram tudo que você está oferecendo. O retorno não é imediato, tem uma particularidade de como eles irão demonstrar ao longo do ano inteiro ou de um mês ou de um semestre. Quando você propõe algo para eles no dia a dia a reposta não é imediata, você vai vendo ao longo do tempo. Você tem três, quatro ou cinco bebês de seis meses, cada um vai demonstrar de um jeito. Não dá pra separar o cuidar e educar. E não só com os bebês, cada faixa etária tem a sua necessidade.

\section{O que considera importante para o trabalho com os bebês?}

Quando trabalhamos com os bebês nada acontece rápido, aos poucos você vai tendo o retorno e respeitar a criança dentro do coletivo, saber qual seu tempo de aprendizagem, saber e entender que você será seu referencial no tempo que estiver com ela na creche. As crianças bem pequenas têm muito a nos ensinar. Você pode conversar com ela não só com palavras, mas com gestos, carinhos, na música, nas brincadeiras... você tem que estar feliz, inteira, aliás para tudo na vida!

\section{Como vocês planejam o trabalho do dia a dia?}

Temos um planejamento dentro de uma sequencia didática durante a semana na qual colocamos propostas diversas e simultâneas. Tentamos compor o espaço da casinha com várias linguagens: faz de conta que é algo do dia a dia das crianças; cuidamos para que tenha um cantinho bem aconchegante para folhear os livros; tem o painel das famílias. Quando planejamos o dia a dia organizamos a nossa vida aqui dentro e também o dia deles. Temos também um planejamento que é de projeto, atividades propostas com dicas e interesses do grupo de crianças.

\section{Como é o grupo deste ano? Como foi o período de adaptação?}

O grupo desse ano chegou bem pequeno e cada vez parece que eles chegam mais novos! Temos filhos de funcionário, professores e alunos. Os filhos dos alunos entram menores porque os pais voltam às aulas. Este é um grupo bem bacana. O período de adaptação foi tranquilo, mas às vezes algumas adaptações são difíceis porque a criança fica no espaço com uma rotina completamente diferente da casa dela, com adultos que elas nunca 
viram. Primeiro você conquista a confiança dos pais porque é seu bem maior do mundo que está em nossas mãos. Tiveram algumas adaptações difíceis, mas as minhas foram fáceis.

Gostaria de saber um pouco sobre os tipos de registros que vocês fazem aqui na creche

No dia a dia temos tabelas que registramos o horário que a criança dormiu, acordou, como foi a alimentação (se comeu bem, se comeu pouco), os banhos e trocas. No início do ano explicamos às famílias que este banho não substitui o de casa. Esses registros das tabelas são trocados semanalmente e os pais têm acesso. Temos outro tipo de registro de cada criança de como ficou nos primeiros dias, como foi a adaptação. Qualquer educador pode pegar este caderno e anotar aquilo que acha interessante ao longo do semestre da criança. Eles nos ajudam na escrita do relatório individual e no plantão quando atendemos os pais no começo do ano logo após a adaptação e no segundo semestre (fora os plantões, temos conversas no dia a dia com os pais). Temos também os registros do planejamento. Depois de cada atividade que propomos registramos os movimentos e dicas das crianças. Essas dicas nos auxiliam a planejar outras atividades.

Gostaria de saber o que você entende sobre documentação pedagógica.

Acho que documentação pedagógica é tudo o que a gente faz, são os documentos que temos do planejamento, as pastas-memória, as reuniões pedagógicas que temos com a coordenadora pedagógica ou com a psicóloga a cada quinze dias. Temos um caderno de registro para escrevermos o memorial que nos comunicamos com as meninas da manhã, além da conversa ou algo que acontece no período, as formações continuadas também são registradas, as pastas-memória que contam um pouco dos grupos de crianças, além dos relatórios de grupo e individual. Acho que tudo passa a ser um documento e as fotos que já falam por si.

\section{Transcrição entrevista educadora "M" (47 anos)- 27/set/2012}

\section{Qual sua formação?}

Minha formação é pedagogia e fiz duas especializações. Uma na área de artes e outra agora em psicopedagogia.

Há quanto tempo está na creche e como chegou aqui? 
Estou na creche há 12 anos e cheguei aqui porque trabalhei em uma outra creche que é vizinha aqui, do hospital Albert Enisten e as funcionárias de lá falam daqui. Eu na verdade não conhecia aí apareceu o concurso e eu prestei.

\section{Há quanto tempo trabalha com os bebês?}

Estou na educação infantil desde 89 e aqui na creche uma boa parte dos anos trabalhei com o módulo I. No módulo II trabalhei somente um ou dois anos. Com os bebês eu estou desde o ano passado até este ano.

\section{E foi você que escolheu trabalhar com os bebês?}

É uma faixa que me fascina bastante, eu gosto muito. Acho que essa primeira faixa de zero a três super parecida, os bebês tem uma delicadeza maior, mas eles são todos delicados até o amarelinho. Eu gosto de todos e mesmo dos maiores. Não sei se você já fez alguma observação ou já teve algum contato, mas eles são muito pequenos ainda. É claro que tem outros tipos de desafios conforme vão crescendo, mas todos muito pequenos. As creches atendem crianças pequenas. É que os bebês tem uma delicadeza porque estão chegando, se adaptando, mas depois que se adaptam... você já percebeu como eles vão ficando super sossegados... Aqui na creche as escolhas dos grupos vão um pouco pela experiência dos educadores. Os bebês são uma faixa que você tem que ter gosto para atender e uma certa técnica aprimorada porque se é uma pessoa inexperiente ela pena um pouco, então a composição é um pouco desse jeito: tem que ser pessoas que já tenham alguma bagagem. Nós temos muitas educadoras aqui e algumas têm mais experiência com os maiores, então aproveitam coisas de um ano pro outro... se você manifesta sua vontade elas até mudam você de grupo, mas não vai só do seu desejo, vai da possibilidade. Se você manifesta o desejo pode acontecer. Nós tivemos educadores que vieram para os menores este ano. Eu nunca fiz um pedido formal porque gosto de todos os grupos no geral.

Como pensa a especificidade do trabalho com os bebês? $O$ que considera importante?

Tem época que eu fico bem animada quando vejo países que entendem a especificidade com os bebês, valorizam o trabalho e o educador que atende, mas essa não é a nossa realidade. Você tem que fazer de conta que está tudo bem para você ser feliz porque você vai ouvindo ao seu redor a dificuldade que as pessoas têm de entender o que é o desenvolvimento de um bebê, o quão precária é a ideia que elas têm... isso é muito ruim! Inclusive dos governantes. O Kassab acabou de tirar a necessidade de ter formação para atender zero a três anos. É muito fadado ao nada e dá uma pena porque quem observa minimamente percebe que é mágico, que é uma fase de um ‘bum' que é maravilhoso! Mas a 
gente não pode desanimar, às vezes eu fico chateada e penso 'Nossa, que horror', mas é o que temos. Para se trabalhar com os bebês é preciso um entendimento dessa faixa etária e a possibilidade de desenvolvimento de um trabalho porque se a pessoa chega achando que não vai acontecer nada, que é só um trabalho mecânico porque são muito pequenos será um trabalho inútil. Você tem que gostar e isso faz diferença. Tem gente que diz que é só ter a técnica, mas eu acho que não. Tem que gostar da faixa etária porque tem essa coisa do afeto. É diferente de outra fase da vida como na universidade, por exemplo, que a pessoa consegue mesmo não tendo um grande afeto. Com bebês tem que ter afeto, senão não dá. Você tem que acreditar no trabalho e que é importante.

\section{Como vocês planejam o trabalho no dia a dia?}

Nossos planejamentos formalmente têm algumas formas: o planejamento que a gente faz uma vez por semana, temos também uma planilha como se fosso uma sequencia didática semanal para não deixar que nada passe, então em cada dia nos dedicamos mais a algum aspecto e vamos observando o que é mais interessante para as crianças. E tudo vai muito da observação dos bebês porque eles vão demonstrando os interesses e nós vamos trazendo coisas que tem a ver com nosso planejamento. Temos este aspecto da observação, mas tentamos teorizar um pouquinho. Por exemplo, a Silvana veio com essa temática da África então fomos por aí. As crianças gostam muito de tudo que você traz então fomos lendo algumas dicas, trabalhando com esses elementos e trabalhando por aí.

\section{Como é o grupo de crianças deste ano? Como foi a adaptação?}

Todo ano é um ano, é sempre uma mesma faixa, mas modifica um pouco porque tem aquele que chegam menores. Tem alguns anos que esses pequenininhos vem com mais dificuldade de se adaptar. Mas este ano não, eles são muitos interessantes esses 4 pequenos. Eles caem, alguém encosta, mas eles se refazem e vão. Já os maiores, temos um grupo de criança bem centrada e pouca dificuldade com crianças que batem. Tem uma só com maior dificuldade, mas no geral dá para levar bem o grupo. Tem anos que a adaptação é mais rápida, tem anos que dá mais trabalho. Eu sempre pego umas mais difíceis, mas sempre dá certo, chega uma hora que fica tudo bacana.

\section{Quais os tipos de registros que vocês fazem?}

Temos um combinado de registrar uma vez por semana. Para este desenvolvimento individual temos um caderno com os nomes das crianças e um tempo para fazer isso. A gente sobe e cada uma vai colocando como a criança está se desenvolvendo, do que está gostando e isso vira um relatório individual depois que vai para os pais. A gente também aproveita esse caderno para os atendimentos individuais que é feito duas vezes por semestre. A gente 
também faz o planejamento que é nosso das atividades, é mais pra gente mesmo. Vamos jogando tudo ali porque quanto mais elementos tivermos será melhor depois para o trabalho em si e para desenvolver o relatório de grupo. Tem também registros do grupo mesmo como a tabela de controle de alimentação e cuidados porque para esta faixa é importante.

\section{Qual importância você atribui aos registros?}

Acredito que fazer registros é importante porque a gente se olha. A creche tem um percurso e cada educador tem seu percurso individual, mas este tipo de planejamento que fazemos iniciou com a outra coordenadora. Antes de eu entrar aqui eu fazia registros, mas não dessa forma que essa coordenadora colocou. Todo mundo aprendeu um pouco desse jeito com ela e ele permeou todos os espaço e grupos da creche. Todas as educadoras à sua maneira fazem esse planejamento recriado: umas fazem digital, outras no caderno, mas todas tem esse percurso que é de observar, anotar e poder rever a prática. Depois que você vê pronto que compreende o percurso. O planejamento virtual é bom quando é individual, mas como nós fazemos assim juntas acho mais fácil nas folhas, para conversarmos as três.

\section{E qual uso fazem desses registros?}

$\mathrm{Na}$ reunião com os pais do final de ano entregamos para os pais um registro do ano todo que é o relatório de grupo. Contamos desde a primeira situação a partir dos registros, vamos contando tudo que aconteceu e compomos com esses registros para fazer este relatório final. Esses registros ajudam para o relatório e também para fazer a exposição porque é como uma linha do tempo...

\section{E qual uso fazem das fotografias?}

Utilizamos muito as fotos e elas são bacanas nesta faixa etária porque as crianças ainda não falam, os grafismo são representados de forma mais simples. Às vezes algum percurso que está acontecendo, com as fotos você registra tudo dessa exploração das crianças, desde o começo do desenvolvimento e de como ele é transformado, tem que ser um bom observador para conseguir ver. Se você consegue ficar minimamente de fora consegue ver desde o começo quando começou e foi transformado. A foto é importante para isso porque ela fala depois.

\section{E quando vocês utilizam essas imagens? Vocês voltam a elas para olhar? Em que} momento?

Para as crianças se é alguma coisa muito significativa a gente imprimi e leva para eles para refazer o planejamento recriado - vamos até fazer essa semana isso e eles acham o máximo. Mas temos um olhar mais atento para essa foto quando vamos finalizar com a exposição. Cada atividade que foi desenvolvida será ressaltada com as fotos, procuramos 
mostrar a sequencia das ações, como ela foi elaborada e modificada. Então temos que dar uma boa olhada porque a gente vai tirando, tirando... A gente dá uma boa enxugada, vê o que interessante e manda para a impressão. Depois da exposição essas fotos vão para a pastamemória, mas essa é uma coisa que a gente ainda está no processo. Temos várias prontas, algumas para acabar, mas também para guardar todas não tem tanto espaço e essa é uma discussão na creche. Tem gente que não acha tão bacana.

\section{E quando elaboram essas pastas?}

No geral, produzimos essas pastas depois da exposição porque você já tem todo o material, então junta tudo e produz a pasta. Mas tem que pensar mesmo porque fica muita coisa e depois ninguém volta lá para acessar, por isso a gente tenta dar uma enxugada, guarda o que for importante e o resto...

\section{O que você entende sobre documentação pedagógica?}

Temos falado sobre documentação pedagógica. Não é um tema super desenvolvido, mas já temos falado sobre ele nos últimos dois anos. A coordenadora e a diretora vem com essa ideia e a gente vai entendendo o quão importante é para a instituição porque vai dando vida às coisas e é importante para quem chega depois para entender o processo. O que você registra você sabe que aconteceu, então sabemos que é importante, mas também sabemos que existem outras formas de fazer e a gente tem que ampliar. Acho que quanto mais formos deixando essas marcas será interessante para a valorização dessa faixa etária, para ela aparecer mais, para o entendimento das pessoas que não conseguem saber o que o trabalho com criança tão pequena. Aqui no dia a dia vemos as mães que não tem ideia sobre o que é o bebê delas e quando elas veem ficam tão encantadas com aquilo que não acreditam. Acho que também pode ser muito importante para os educadores que estão iniciando, que estão lá estudando, mas não tem ideia do que seja o trabalho com criança tão pequena. Quanto mais elementos tivermos para ajudar, todo mundo irá gostar.

\section{$\underline{\text { Transcricão entrevista educadora "S" (31 anos)- 27/set/2012 }}$}

\section{Gostaria de saber sua formação e o tempo em que está aqui na creche}

Tenho duas graduações, fiz letras e pedagogia e faz dez meses que trabalho aqui na creche.

Como você conheceu e chegou aqui na creche? 
Conheci a creche porque fiz pedagogia aqui na universidade e a gente tem um contato direto com as creches para estágio. Eu não fiz o estágio lá, mas conheci. Então prestei o concurso e fui chamada três meses depois da prova.

\section{E há quanto tempo trabalha na educação infantil e em especial com a faixa etária} dos bebês?

Trabalho com a educação infantil há algum tempo porque quando eu fazia letras trabalhava no Labrimp que é ludoeducação e não escola. A faixa etária variava, era de zero a quinze anos em um espaço diferente, um contexto diferente. Agora, minha experiência em instituições de ensino com crianças menores são quando trabalhei na creche dos funcionários do Albert Einstein onde trabalhei com os bem pequenos, berçário igual aqui, e também trabalhei em uma escola particular na Vila Madalena também em berçário durante um ano. Foram dois anos no Albert Einstein, um ano nessa escolinha e ao mesmo tempo trabalhava no Labrimp onde tinha acesso a outras faixas etárias.

\section{E quando você veio para cá, foi você que escolheu trabalhar com os bebês?}

Quando cheguei aqui na creche já era novembro então a creche estava resolvida, já estavam finalizando os trabalhos e o espaço que precisava de mais apoio era o grupo azul. Eu fazia um horário intermediário que agora é um horário da estagiária. Eu fiz o teste desse horário e foi legal porque a gente ajuda nos horários de pico da manhã e da tarde. Fiquei por um mês e meio no grupo Azul e estava bem feliz lá. Para este ano não pedi nenhum grupo porque aqui na escola tem esse movimento de pedir a alocação. Às vezes você consegue, às vezes não, mas eu não cheguei a pedir, me colocaram e eu fiquei satisfeita.

\section{E como você pensa a especificidade do trabalho com os bebês?}

Gosto muito de trabalhar com os pequenos porque é um desafio mesmo dentro da pedagogia. Quando se fala de 0 a 3, não pensa no zero, fala-se do quase 3 sempre, mesmo na Faculdade com os textos que são lidos, os relatos de experiência ou os livros, é sempre muito difícil ter pesquisas com os bem pequenos mesmo. Quando se fala do 0 a 3 pegam essa faixa toda, mas sempre se referem ao quase 3, aos 2 anos e meio, mas nunca do zero. Então por isso é bem desafiador porque você não tem onde buscar e na creche é interessante porque a fonte são as experiências das pessoas que estão aqui há mais tempo e que já passaram por este grupo mais de uma vez, ou seja, tem essa coisa empírica. A faixa etária dos bebês é o primeiro passo tão importante. Eu já consegui enxergar tantas coisas que mostramos para eles que é um pouco do que eles vão carregar, por isso traz responsabilidades e por isso temos que mostrar outros caminhos, mas ainda é um campo a ser explorado, não tem muita gente que pensa sobre isso. 


\section{O que considera importante para se trabalhar com os bebês?}

Para se trabalhar com os bebês é preciso uma sensibilidade diferente com relação à escuta. Vivemos numa sociedade muito pautada no discurso e na linguagem oralizada, de palavras. O peso dessas palavras os bebês irão aprender comigo, mas por enquanto é outro tipo de escuta: você ouve um choro, um olhar, um sorriso. Isso é encantador para mim saber que essa relação humana pode existir ainda porque as crianças um pouquinho maiores já estão muito pautadas nessa coisa de linguagem e discurso por palavras. Com bebês é outro tipo de relação, outro tipo de conversa porque a gente conversa de um jeito diferente. É uma conversa mais sincera porque o discurso vai se transformando: pensamos uma coisa, dizemos outra e fazemos outra ainda. Lá no Azul não é tanto assim porque tem essa conversa diferente, o olhar não consegue mentir. É importante ser sensível para esta conversa que é diferente, passamos a falar de forma diferente e também ser ouvida de uma maneira diferente. De fato, eles não entendem tudo que estamos dizendo, mas há outras coisas envolvidas nessa conversa que é diferente.

\section{Como vocês planejam o trabalho do dia a dia?}

É algo que estou aprendendo, tive a sorte de trabalhar com a "L" e a "M" que já estão aqui há mais tempo e são pessoas maravilhosas. Por ser meu primeiro ano eu não poderia estar com pessoas melhores. Eu demorei um pouco para entrar nessa dinâmica porque temos o período de adaptação, as famílias e esse formato que a creche tem de adaptar. O fio do projeto começa na adaptação, neste primeiro contato com as crianças vão surgindo coisas e pensamos “Puxa, que legal!" e assim puxamos o fio daqueles interesses e experiências que temos e também daqueles interesses que vamos vendo nas crianças. Depois que estrutura um pouco a ideia do que estamos trabalhando vão surgindo muitas ideias e nós esperamos as dicas porque podem ser ideias que estão em mim e não neles, então quando vemos uma dica pensamos que agora já dá para fazer aquela atividade que estávamos pensando porque realmente agora eles estão pedindo isso. Às vezes dá até um desespero porque na correria da rotina, do ano passando e do tempo acabando pensamos que não dará para fazer algo que consideramos interessante e legal, é tudo super apertado dentro de uma rotina que é muito dinâmica deles, mas respeitamos muito o humor deles e eu acho isso muito bonito. Tem dia que é mais difícil... mas tudo bem, depois fazemos de outro jeito e tudo bem porque respeitamos esse ritmo. No grupo Azul são difíceis as coisas que eles conseguem fazer junto com a gente, tem muita coisa que temos que produzir, então primeiro temos que conseguir produzir, montar o material para que eles possam interagir com aquilo. Às vezes conseguimos preparar todo o 
material, mas a atividade não flui, então fica para outra semana. O planejamento vai muito neste sentido. A gente planeja e executa de acordo com as possibilidades e os ritmos deles.

Como é o grupo de crianças deste ano? Como foi o período de adaptação?

O grupo deste ano é bem tranquilo, agora estamos entrando em uma outra fase porque eles estão começando a andar e estão surgindo alguns conflitos, mordidas, é esse contato com o corpo do outro que ás vezes não tem muita regra, pode machucar e a gente tenta não construir só o discurso do 'não, não pode!', mas é um grupo bem tranquilo, sossegado que interage muito bem. Durante a adaptação tirando um ou outro, de maneira geral foi bem tranquila a chegada deles, não tivemos muito conflito, uma ou outra família foi um pouco mais difícil, mas sempre tem porque as expectativas são diferentes, mas não acho que tenha sido nada do tipo "nossa, que grupo complicado!". Teve uma adaptação que foi um pouco mais difícil pra gente, mas uma vez que o grupo estava estabelecido foi muito gostoso de trabalhar.

\section{Gostaria de saber um pouco sobre os registros que vocês fazem.}

Temos o registro do planejamento com as atividades que a gente planeja, como foi, o que não deu para fazer, o que a gente tem que refazer. Às vezes é um pouco caótico este planejamento, vamos escrevendo, puxando flechas, então precisamos de um tempo para sentar e organizar a ação. Tem esse registro do planejamento do projeto que a gente desenvolve. Temos os registros das reuniões que a gente tem quinzenalmente com a coordenadora pedagógica e com a psicólogoa. Temos um caderno de registro para isso. Temos também um caderno de registro, cada criança tem algumas páginas onde a gente vai registrando, os dois períodos tem acesso a esse caderno e assim conseguimos visualizar um pouco o que eles fazem de manhã que é diferente da tarde e também podemos visitar o que fizemos à tarde. Para este registro temos um horário para fazer que é mais complicado de cumprirmos, seriam

quinze minutos por semana com dois educadores. É um horário que a gente tem um pouco mais de dificuldade, mas às vezes estamos lá, cuidando da sala do sono e aproveitamos para fazer o registro. Eu acho que a gente escreveria bem mais se isso estivesse mais dentro da rotina, esse registro é um pouco mais complicado, mas utilizamos para fazer o relatório individual.

\section{Como vocês fazem o relatório individual?}

Para fazer esses relatórios dividimos as crianças pelas educadoras por conta do tempo mesmo. Seria bem interessante sentarmos todas juntas para falar de cada criança, mas dentro da dinâmica de trabalho que temos não dá. Nós temos seis horas de trabalho na creche, mas seis horas com as crianças. 


\section{Realmente, essa falta de tempo para organizar o trabalho é algo geral na educação} infantil, não é?

Temos uma hora por semana, mas é pouco, então por conta disso a gente divide as crianças. Tem um número de horas que vale a produção do relatório... Outro registro que temos é o da rotina que ficam lá onde tem informações sobre a alimentação do bebê, horário de sono... também são registros, servem mais para as famílias, mas servem para pautar a nossa organização de trabalho lá.

\section{Você poderia falar um pouco do uso das imagens, das fotografias?}

As fotografias fazem parte de uma dinâmica necessária dos educadores. Em geral, quando planejamos alguma atividade do projeto a gente pega a câmera e registra. As educadoras da manhã levam a câmera quase sempre e fazem muitas imagens da rotina que muitas servem pra gente também. Elas têm um pouco mais familiaridade com o registro fotográfico. Eu tenho um pouco mais de dificuldade, é um pouco meu isso porque até buscar a máquina eu perco o momento, então eu prefiro estar ali e fica mais difícil porque fica na minha memória, no meu registro escrito, mas eu tenho um pouco desta dificuldade. Eu penso 'puxa, que legal que está aqui', mas vou sair daqui para buscar a máquina? Não vou... essa é uma dinâmica da creche que eu estou me acostumando, penso que poderia ter fotografado isso, mas eu não consegui sair dali... temos essa disposição das fotos e é muito legal, as crianças dão um retorno muito positivo quando se veem lá e se reconhecem ali. Temos as fotos das famílias que compõe o espaço deles e que eles vão se aproximando. Primeiro é algo que não reconhecem, depois reconhecem a mãe, depois se reconhecem e depois reconhecem os amigos. Ao longo do ano vemos o quanto isso é importante para eles. Nas atividades que fazemos com fotografias deles percebemos o quanto é importante para eles rever aquele momento apesar de serem bem pequenos. Eles estão expostos a muitas coisas imagéticas na creche. Mesmo as imagens que não são fotográficas tem uma resposta super valiosa, por exemplo, quando eu levei o djembê, o instrumento, e outra vez levei uma imagem super abstrata de um djembê embaixo de uma árvore para ver o retorno deles e a primeira coisa que a Luana fez foi tocar o instrumento da imagem. Então, este reconhecimento que eles têm das imagens é por conta do contato do dia a dia que eles têm.

\section{Pude perceber que vocês fazem um trabalho grande com imagens...}

Essa é uma perspectiva de entendê-los como pessoas, eles são pessoas, não tem o momento em que passam a ser, então eu sou bem assim mesmo, o que eu vejo e acho legal eu mostro. Não existe essa coisa do infantil, do 'para bebê', sempre alguma coisa irá causar, tem 
muito menos a ver com faixa etária e sim com possibilidades que podemos oferecer, por isso a imagem está sempre presente, não só a fotográfica, mas as imagens de maneira geral.

E as fotografias que tiram, você retomam? Voltam a olhar para elas depois? Sei que vocês usam muitas delas para a exposição...

A exposição é importante, eu não vivi ainda, mas acho que é na exposição que nós teremos um pouco mais de tempo para rever de fato as fotos, se quisermos mostrar as fotos tocando os instrumentos, iremos lá procurar as fotos que tem as crianças tocando. A fotografia é isso, especialmente com a câmera digital porque você tira mil fotos e depois para selecionar isso é um outro trabalho que exige um tempo e na correria que a gente vive não dá para sentar lá e ver mesmo, olhar a fundo e ver que tirei uma foto de uma criança, mas na mesma imagem tem outra criança lá atrás fazendo outra coisa, então não dá para fazer isso. É na exposição o momento que a gente consegue dar uma olhada mais geral.

\section{Mas ao longo dos planejamentos vocês olham essas fotos?}

A gente tira as fotos, descarrega e conversamos sobre uma foto muito boa, outra que um bebê está fazendo tal coisa, então quando descarregamos damos uma olhada geral e de acordo com o que planejamos e lembramos de algo que aconteceu, procuramos se temos o registro fotográfico deste momento, se encontramos, levamos para eles, na medida que o planejamento pede levamos para eles. Esse trabalho com os instrumento é isso, levamos os instrumentos, eles estão explorando, estamos levando referências imagéticas diferentes dos instrumentos, mas também queremos mostrar a eles que eles são uma referência imagética pra gente, por isso temos o registro fotográfico deles interagindo com aquele instrumento que mostramos, é uma retomada. Mas acho que essa retomada geral será quando montarmos a exposição por conta do tempo.

Gostaria que você falasse um pouco sobre o que entende sobre documentação pedagógica

Ainda não passei por este momento na creche, mas sei que existe o registro dos projetos. Cada grupo monta depois o que chamamos de 'pasta memória' que é o registro do projeto desenvolvido naquele grupo, daquele ano. Estamos tentando organizar o acervo gigante que a creche já tem... eu não vivi esse processo de fazer e montar a pasta, saber como a gente organiza esses registros, mas com certeza é um tipo de documentação valiosa porque registra a passagem de cada criança em cada agrupamento desde a entrada dela na creche até a saída. Eu acho que isso é documentação. Agora, essa coisa do que documentar e como documentar eu não sei teoricamente, conheci um pouco nas disciplinas da faculdade, mas aqui na creche, neste uma no que estou não tivemos nenhuma formação sobre isso, mas lembro que 
no começo do ano, durante a formação foi um palestrante falar justamente disso, da importância desse registro. Acho que só pelo fato de já produzirmos as pastas memória já vamos ao encontro do reconhecimento da importância dessa documentação. 
APÊNDICE C - Transcrição da reunião de orientação do dia 29 de outubro

\section{Transcriç̃o reunião de formação ${ }^{15}$ - 29/10/2012}

Inicia-se a reunião com uma discussão para organização das ações para a exposição do Grupo Azul que envolve o revezamento das educadoras para que saiam da sala para a montagem e a sistematização para a impressão das imagens.

$\mathrm{CP}$ : com relação à revelação de fotos estamos com uma grande questão na creche... usamos muita tinta nesta reta final. Muita tinta significa todo o nosso estoque, pedimos emprestado para a outra creche e acabou. Já foi um novo pedido para a tesouraria, mas até liberar o dinheiro para a compra é um processo demorado. Hoje de manhã conversamos e o que sugeriu-se foi imprimir lá embaixo. Lá tem uma impressora colorida, mas precisamos nos organizar. E qual é a orientação? O Grupo Verde que é o primeiro colocará tudo em um pen drive e especificar o que querem grande e o que querem pequeno aí a Sandra vai descer e imprimir essas fotos. Dessa forma não precisaremos usar o dinheiro da caixinha. Fizemos o cálculo e gastaríamos mais ou menos trezentos reais com a compra dos toners. É um dinheiro grande! Pensamos em revelar que também daria, se for muito complicado imprimir partimos para a revelação das fotos

EL: Mas para revelar também não é muita burocracia?

CP: Não, para revelar também usaríamos o dinheiro da caixinha.

EM: Tudo bem que essa tinta vem pra gente e a universidade banca, mas as revelações sustentam melhor, a qualidade é melhor, a não ser que a gente começasse a comprar o papel próprio para imprimir fotos porque dá pena. É algo que gasta tinta, a tinta é cara... tem que fazer essa conta.

EA: E a gente acaba passando contact pra durar mais...

CP: Uma coisa que ficamos pensando é que agora estamos na transição entre revelar e imprimir na creche. Até o ano passado a gente revelou uma parte e imprimiu outra parte. Este ano não, não revelamos nada de foto, em contra partida imprimimos muitas fotos, fomos brincando com os tamanhos das imagens e isso também foi importante, teve uma seleção pra

\footnotetext{
${ }^{15}$ As seguinte legendas são designadas para nomear as autoras das falas:

$\mathrm{CP}$ : coordenadora pedagógica

$\mathrm{J}$ : Juliana, a pesquisadora

EM: educadora "M" do período da tarde

EL: educadora "L" do período da tarde

EA: educadora "A" do período da manhã

Nota-se que nesta reunião não estavam presentes as demais educadora do Grupo Azul, pois não havia como garantir o atendimento das crianças se elas deixassem a sala de aula.
} 
isso. Eu acredito que aí que temos que chegar, temos que fazer os cálculos. Quando imprimimos muita coisa é muito papel e qual finalidade que ele tem? Será que depois ele é conservado inteiramente para compor uma pasta-memória? ou será que teremos que imprimir de novo para a pasta? É algo que teremos que discutir mais pra frente, mas agora temos uma questão pontual que é a exposição do verde e do azul. O que eu queria pedir é para vocês se organizarem, sei que já estão bem organizadas, eu pego o pen drive de vocês e lá está tudo arrumadinho, mas precisamos organizar ao máximo, separar uma pasta de fotos para a exposição, dizer os tamanhos das fotos que vocês querem porque não dê para uma de vocês imprimirem, então podemos enviar uma pessoa daqui se já estiver tudo separado. Isso deve ser feito com uma certa urgência. Com relação aos relatório eu já mandei alguns e-mails, algumas devolutivas. (...) Agora entramos numa meta, o relatório, o corpo do relatório já está todo estruturado, mas agora vem o recheio que são todas as atividades, os projetos e como vocês selecionaram isso. Culmina tudo, né: o relatório, todo o processo que vocês viveram, a exposição que é a síntese de tudo que vocês viveram mais a reunião de pais, então você terão 3 momentos, podemos dizer 3 atividades de culminância dentro do Grupo Azul. São três momentos que envolvem uma documentação, envolve os registros que vocês fizeram sejam eles do dia a dia, do planejamento, mais do grupo ou mais individual, mas entramos em um ponto importante que é a documentação. Sobre documentação temos pouquíssimos materiais de zero a três, pouquíssimos mesmo na literatura, seja no Brasil ou fora. Então, vamos tentando construir a partir do que a gente faz, por exemplo a educadora "A" que desceu para falar na disciplina de educação infantil do curso de pedagogia. Ao mesmo tempo que tem pouco material tem muita gente querendo ouvir sobre, querendo entender como a gente faz no dia a dia. Fomos tentando pensar em algum material, algum texto que pudesse falar mais especificamente dessa documentação que é feito de zero a três, então a Juliana indicou um texto que eu já conhecia, provavelmente vocês já ouviram falar... é um texto para apoiar aquilo que vamos falando na reunião, você quer falar um pouco dele Juliana:

$\mathrm{J}$ : Acho que é isso é isso que você falou um pouco, que ele traz a prática dos pequenos que é difícil de encontrarmos, traz também imagens que muitas vezes sentimos falta quando lemos algum material. E pelo que pude ver da experiência do período da tarde acho que tem coisas que vocês já fazem como a escuta sensível, escutar a crianças e registrar... tem muito a ver com o trabalho que vocês fazem, então é um texto que vem ao encontro.

CP: Aqui tem alguns exemplos de como eles fazem, mas por que estamos falando disso? Por que utilizamos uma reunião de grupo para falar sobre isso? Justamente para pensarmos os nossos próprios processos, dentro do nosso grupo o que a gente faz, e para que a gente faz. 
Algumas coisas fomos pensando dentro do caminho do grupo azul, seja os murais para compartilhar mais com as famílias... tudo isso envolve a participação das famílias dentro de um contexto que fica mais o educador e a criança. Tudo aquilo que a gente faz dá visibilidade aos bebês, mas ao mesmo tempo precisamos perguntar que visibilidade é essa? A exposição do Azul fecha o nosso calendário de exposições da creche, foi uma exposição que a gente construiu pensando muito em como fazer porque este trabalho pedagógico é subjetivo, fica nas entrelinhas, mas vai se expressando através de uma foto. A gente percebe que os grupos de zero a três tem muita foto mesmo porque temos o processo, temos a experiência, mas o que a gente consegue documentar vem com a foto. Ela traduz muito essa experiência, não sei se vocês sentem dessa forma... pensamos se vocês tem alguma sequencia de imagens que irão trazer ou que vocês tem e não irão trazer para a exposição, mas irá para o relatório... uma sequencia em que vocês conseguiram acompanhar o passo a passo de uma criança ou de um pequenos grupo de criança, uma experiência que vocês tenham documentado e que isso valeu para vocês escreverem o relatório, tem alguma sequencia marcante desse ano, do projeto que está de alguma forma registrada? Via foto ou via registro do planejamento, você conseguem lembrar do processo de vocês?

EM: o processo do projeto da tarde do jeito que ele está vai ser escrito, ele está pontuado. Cada atividade foi fechada, registrada. O dia em que você (referindo-se à Juliana) registrou ficaram ótimas as imagens porque a gente se mata para registrar. Temos que estar no contexto, sair para fotografar, vai e volta e é muito ruim. Eu tento sair para fazer, mas não sou muito boa fotógrafa. No dia em que a Juliana fez ela ficou sentada, isolada da proposta... mas todo o processo vocês verão na exposição, tudo está documentado. Cada situação revela bem a dica das crianças, a atividade que vem depois.

EA: Lembrei de uma situação que eles faziam bastante com o pé e a questão do espaço. Outro dia arrumei a sala de sono pra assistirmos um filme da atividade do projeto, logo que o Benício entrou começou a cantar a música que tínhamos apresentado e a dançar sozinho, então pensamos sobre o espaço, como o espaço organizado daquela forma remeteu ele àquela experiência. Tem outras coisas também... ele fizeram uma brincadeira a tarde com as mãos, estavam as mãozinhas desenhadas na parede, aí eles foram para o pátio da casinha, puseram as mãos na parede e começaram a cantar. Era alguma coisa que eles tinham vivido a tarde. Não entendemos bem o que era, mas só essa não documentamos, mas todas as outras nós registramos. Temos também bem pequenos vídeos...

CP: Quando vamos organizar um material para apresentar fora temos que fazer uma seleção, então a gente pega todo o material que é fotografado, todo o material de vídeo mais o material 
registrado para você escrever uma síntese o trabalho é grande. É grande porque você tem muito material à mão para escolher e fazer este processo, não é fácil. Então a exposição e o momento do relatório são momentos para isso, vocês só me entregaram a parte da rotina do relatório, aliás até uma coisa que fiquei pensando quando li o relatório de vocês: tem muita coisa que a gente escreve que eu não sei se temos que escrever no final do ano, se não teríamos que escrever no início do ano. Fiquei pensando, acho que a documentação permite isso, o olhar depois... eu já li muitos relatórios, mas pela primeira vez fui lendo este ano e pensando se não enviamos isso para os pais antes. Por mais que a gente diga na reunião de pais, no relatório vocês dizem tão claramente como se organizam os momentos, então pensei se não poderíamos elaborar um material que a gente pudesse entregar aos pais quando as crianças entram no berçário, no dia da reunião do berçário.

EA: É porque todo ano acaba escrevendo as mesmas coisas, não as mesmas coisas, mas coisas referentes aos mesmo assuntos e depois fica tão longe.

CP: É isso, fica tão longe, peguei o trecho de adaptação, fui lendo, fui lendo, e agora? Porque isso já é verbo do passado, já passou, eles já viveram... acho que é um texto que a gente pensando, vamos elaborando juntos, mas podemos entregar no início e no fim, já que temos só um relatório de grupo anual, poderíamos entregar as experiências com os projetos, assim como é com os outros grupos. Os outros grupos não tem esse detalhamento todo que a gente em no Azul, eles contam uma introdução do movimento geral do grupo e depois vem os projetos e outras experiências fora deles. Acho que poderíamos pensar nisso. Tem muito material bacana, coisas que vocês escrevem e escrevem com propriedade que se enviado no início do ano já dê conta.

EL: Se isso for no começo do ano irá fazer os pais entenderem a importância da adaptação que não precisa ser a longo, longo prazo.

EM: (...) Imagina um pai que vem completamente leigo, ele não sabe muito o que vai encontrar ali, por isso que eu comentei uma vez a surpresa de uma mãe quando ela veio e participou do momento de grupo. Ela ficou encantada. Ela não conseguia compreender o quanto o bebê pequeno é capaz, então eu acho que é melhor porque assim eles podem compreender como será o movimento do ano.

EL: É eu acho que no começo eles podem ler e ir acompanhando o que está acontecendo na prática.

CP: Vocês dizem tudo isso na reunião de pais, a estrutura da reunião de pais é toda essa, mas ao receberem um material concreto assim como recebem no final do ano, muito do que está ali eles poderiam acompanhar. Vocês falam da adaptação, falam do objeto de apego na 
reunião, mas lá é muita informação para um dia só. Acho que valeria a pena a gente pensar em um material, poderíamos pensar em uma diagramação que não fosse muito pesada, que fosse mais informativa, que pudesse vir com algumas fotos... eu fiquei pensando nisso. Aí no final do ano a gente conta as trajetórias dos projetos, as narrativas das crianças. Deixamos os pais a espera dessa experiência do que as crianças fizeram.

EL: Porque na reunião de pais deste ano a gente usou um pouco as imagens do ano passado, mas ficou só naquele momento da reunião. Se juntarmos as imagens com este texto pode ser importante para eles.

CP: A estrutura do relatório está pronta, então agora vocês irão rechear com os projetos. Eu já li lá, coloquei uma data... sei que está em cima, mas vocês já tem tudo bastante organizado. No ano passado eu já recebi o texto com algumas imagens que ilustravam bem o texto, mas este ano se vocês não conseguirem colocar as fotos não tem problema, mandem pra mim o texto.

EM: Vamos tentar, temos vontade de entregar inteiro, vamos ver.

(...)

(discute-se um pouco a capa do relatório, a possibilidade de uma foto coletiva do grupo, estrutura do cabeçalho do relatório)

CP: Agora para a gente poder entrar um pouquinho na discussão do texto porque afinal não temos muito tempo, eu selecionei um trecho, a Juliana também selecionou outro. É um texto que fala da documentação pedagógica em contexto de creche: a partilha do poder escrito pela Ana Azevedo e Joana Souza. Eu tenho lido muito material de documentação da Ana Azevedo. Elas são de Portugal, da Associação Criança, junto com aquele pessoal da Júlia Formosinho. É um material bastante interessante, principalmente na defesa que eles fazem o tempo inteiro da pedagogia em participação. É claro que isso é um artigo com 17 páginas, mas pegando um pouco do que a gente vive na creche, eu tentei selecionar um trechinho aqui na página 3 . Tem uma sequencia de fotos para pensarmos como fotografamos nossas sequências. Eu até escrevi um material sobre isso, sobre a cultura da criança e a cultura do adulto e o quanto a documentação permite isso. Quando todos estão iguais no processo, não só o poder do adulto nem só o protagonismo da criança. Esse protagonismo todo que evidenciamos, que damos visibilidade também só pode acontecer porque tem a mediação de vocês. Todas essas experiências que vocês contam só podem acontecer porque vocês tem um olhar e uma escuta para isso.

(CP lê o trecho selecionado) 
“A documentação em creche tem uma importância vital na criação do diálogo entre duas culturas - a cultura da criança e a cultura do adulto - e requer uma atitude ética e responsiva porque as crianças desta faixa etária não verbalizam, através da linguagem convencional (a fala), os seus pensamentos, percepções, gostos, sentimentos, preferências, tal como não verbalizam os sentidos e significados que atribuem às experiências."

CP: É claro que a criança fala de muitas formas, elas não verbalizam, mas se expressam de outras formas.

"Precisam, portanto, de um adulto que as escute, que seja capaz de "ler" os seus sinais, de compreender as outras linguagens que a criança usa para participar, comunicar e narrar. Este é um esforço complexo porque sabemos que a formação das educadoras não as preparou para fazer esta escuta dos sinais das crianças"

CP: Quando a gente fala tanto das dicas, lugar onde temos que aprender, ouvir... vocês já ouviram em algum curso de formação inicial sobre isso? Muitas coisas que a gente vive hoje aqui dentro da creche é fruto dessa formação em contexto. Não falo apenas dos momentos formais de formação continuada, mas do dia a dia. Quando um educador novo chega, por exemplo, a "S", se hoje sentarmos com ela, ela saberá explicar o que é uma dica, mas por que ela sabe? Por que ela teve parcerias experientes que forma dizendo a ela o que era isso. $\mathrm{O}$ curso, a graduação inicial não nos forma para isso.

“A documentação pedagógica é um instrumento estruturante e estruturador da prática porque permite estabelecer pontos de contacto entre estas culturas, analisar e reflectir, em companhia, os processos e as realizações das crianças e dos adultos, arquitectar experiências contínuas e interactivas (Dewey, 1971).”

CP: Isso já estava lá em Dewey, então é uma coisa de longa data. Aqui no artigo vocês verão depois que é um texto para vocês lerem quando quiserem, quando quiserem escrever algo sobre. Tem as sequencias de imagens, você sugere alguma Juliana?

J: Gosto bastante da sequencia de espuma, como a professora sai da situação para se colocar no fazer de escuta, ou seja, registra, fotografa para depois montar este material, então nessa medida é um texto de documentação porque a professora vai contando os processos das crianças. Conta da criança que não gosta, que fica mais afastada e de como a professora vai integrando-a e interpretando-a a partir da pedagogia em participação. A documentação tem muito isso, se voltar para uma teoria e interpretar a partir dele. Essa professora volta para os princípios da pedagogia em participação para analisar, ela divide em eixos. É algo bem específico do fazer dele. Na página 10 é interessante o fecho que ela faz, traz a perspectiva da 
sequência de imagens e sua descrição e interpretação das cenas. Acho que o mais importante desse exemplo é o que ela traz do adulto e da criança. Ela traz as ações das crianças, mas também a mediação e interpretação do adulto, neste sentido, essa prática se aproxima com o que vocês fazem aqui, eu achei muito próximo dessa sensibilidade que vocês têm com as crianças.

CP: Ao longo do artigo elas trazem algumas sequências de fotos dos percursos de cada criança. No nosso caso, documentamos mais o coletivo, ainda não conseguimos documentar as crianças especificamente por conta da nossa realidade, nosso número de crianças. Alguns casos conseguimos, mas nem sempre, vocês mesmo já colocaram de como facilita quando tem alguém que ajuda a tirar as fotos

EM: De fato, este afastamento, este adulto que sai da cena para fotografar faz toda a diferença. Porque esse adulto interage pouco com as crianças e o adulto que está com as crianças tem que estar inteiro. Agora, esse formato individual do texto é bem bacana, mas essa professora deve trabalhar com grupinhos bem pequenos. Você consegue notar cada um dentro do coletivo mesmo que não façamos dessa forma a gente sabe o percurso de cada um. Já falamos várias vezes sobre essa questão de individualizar, mas pra gente, pra nossa realidade é mais complicado.

$\mathrm{J}$ : Acho que neste texto foi uma opção do registro individual de cada criança, poderia ter sido feito do grupo, mas de fato nossa realidade no Brasil é bem diferente. Não temos tão poucas crianças.

EM: O espaço também é diferente...

CP: É, essa questão do espaço é uma questão para nós, por exemplo, o nosso espaço do berçário é muito recortado, durante uma atividade se tiver uma criança dormindo já tira uma educadora do contexto, se uma vai tirar fotos também sai do contexto. É algo que teremos que parar para pensar... se uma tira as fotos, a outra tem que dar conta do andamento da experiências junto com as crianças. É mais difícil, mas vou percebendo o quanto vocês educadoras fazem de esforço para fotografar e registrar. Vamos vendo as imagens do grupo azul e é possível enxergar o olhar das educadoras. Isso é muito interessante no trabalho do berçário. Vocês conseguem captar nas fotografias do azul, não é uma crítica aos outros grupos, muito da alegria, da expressão. É diferente de fotografar todo mundo sentado numa roda. São naturezas diferentes, aí está a delicadeza do processo. Eu vejo que vocês tentam captar essa delicadeza do dia a dia que é muito difícil.

EM: É que é isso que a gente acredita. 
CP: Quando você vê as fotos do berçário você percebe. Eu precisava outro dia de uma sequência de imagens e o primeiro grupo que eu fui foi no berçário porque a essência do que eu precisava contar sabia que encontraria lá. Talvez seja um ponto para trabalharmos nos outros grupos. Acho que hoje tem muita coisa que o módulo I faz que precisamos dizer ao módulo II, precisamos mostrar o nível de detalhamento, o refinamento que temos chegado. Todos aqui têm muito claro quais os princípios que regem nosso trabalho, então se ainda não chegamos no registro individual é porque a gente não tem estrutura.

EA: Mas no relatório individual tentamos contemplar o que é de cada um, vamos contando as experiências de cada um a parir de coisas que só a gente viu. Muitas vezes não conseguimos fotografar porque não cabe na estrutura que temos de organização, mas aparece de algum jeito no relatório individual, apesar de ficar muito intimista e ir só pra família.

CP:É, realmente, nos relatórios individuais aparecem e já tem alguns pedido se não poderíamos colocar algumas fotos individuais nos relatórios individuais.

EA: Eu concordo porque a gente às vezes escreve muito para dizer e se tivesse uma imagem já estaria ali traduzido. Como não tem imagem a pessoa tem que imaginar como foi aquela cena e como ela vai imaginar? Tem que descrever os elementos, escrever, escrever...

CP: Vocês acham que a gente conseguiria fazer? Para este ano não dá, mas podemos pensar... EA: Não, não quero dar ideia porque senão tem gente que não vai gostar.

EM: Pelo tanto de fotos que temos tiradas certamente tem de todo mundo, acho que dá pra fazer sim... e usar algumas foto coletivas é interessante até para os pequenos de quando eles começam a brincar juntos, isso é importante para os pais. Acho que temos material para isso.

EA: Podemos fazer um projeto piloto, quem sabe ano que vem... tentar em um grupo, começar no Azul.

CP: Acho então que podemos pensar em duas coisas como possibilidades: a primeira é a estrutura do relatório onde quebraríamos um pouco e organizaríamos um material para ser entregue no início do ano e deixaríamos as narrativas deles para o final porque assim vocês conseguirão se envolver de outro jeito.

EM: Poderíamos organizar dicas preciosas para os pais de adaptação, cada criança é uma criança, cada vivência é uma vivência, mas tem coisas que a gente já sabe sobre e os pais não. CP: Sim, e a outra coisa que nós podemos pensar é um relatório individual contando um pouco com imagens, com fotos. Podemos disparar essa discussão no grande grupo, no coletivo, mas se ficar muito difícil podemos fazer um projeto a partir do Azul e por que o Azul? Porque é o primeiro ano deles na creche e também porque vocês dividem os relatórios. No Módulo II é mais difícil porque uma educadora faz dez relatórios, mas se tivermos esse 
tipo de material só no Módulo I não tem problema, na passagem para o Módulo II fíca só a escrita. Acho que temos que ir encontrando caminhos. Sobre este texto podemos voltar nele já que fala da documentação como possibilidade de dar visibilidades às culturas das crianças e dos adultos, então podemos voltar nele quando avaliarmos o trabalho desse ano e projetar 2013. Podemos olhar tudo o que a gente fez, tudo o que a gente registrou pensar 2013. Então as educadoras do Grupo Azul do ano que vem já poderão pensar sobre isso.

J: Outro ponto interessante é pensar como o trabalho de vocês pode extrapolar os muros da creche, como mostrar o trabalho de vocês além da escola, como trazer essa criança para ser vista além da escola. Este olhar peculiar que vocês têm para os bebês é muito interessante.

CP: Temos um item no nosso plano de trabalho que é levar nossas exposições para além, mas como fazer isso é outro ponto.

EM: Uma ideia é fazer virtual, fazer um blog. Poderia ter! E muita gente ia querer acessar.

CP: Realmente é uma grande ideia! Uma boa sugestão para levar nossas exposições... sempre pensamos em como fazer algo itinerante porque já é um sacrifício fazer aqui.

EM: Já sabemos um pouco de registro, para filmar a gente patina um pouco, mas temos outras coisas, tem outros lugares que fazem isso e é bem bacana.

CP: É uma boa sugestão. Agora temos que terminar... 
APÊNDICE D - Modelo de termo de consentimento livre e esclarecido enviado à coordenadora e à diretora da creche

\section{- FEOSP}

Săo Paulo. 28 de maio de 2012

A Coordenacao Pedagógica

Prezada Senhora.

Eu, Juliana Guerreiro Lichy, portadota da codula de identidade no 33.350.306-5 na condiça de aluna regularmente matriculada no Prograna de Pos-Graduaçăo da Faculdade de Educaçào da USP, na Linta de Pesquisa Didática, Teorias de Ensino e Práticas Escolares, realizo sob a orientaciso da Profa Dra Mònica Appezzato Pinazza, uma pesqursa de Mestrado sob o titulo provisorio -A voz de quem nà fala, a escuta do nào dizer: documentaça como reveladora das vozes dos bebes".

Com o intuito de desenvolver uma investigaça de campo sobre essa teinatica solicito autorizaça de V Sa para realzar observaçöes, analisar registros produzidos pelas educadoras do agrupamento de criancas estudado e produzir registros escritos e audiovisuais, durante o ano letivo de 2012 Pretende-se compreender como se concretiza, na pratica educativa, os processos relacionas adulto-crianças, crianças-crianças e como isso se revela no plano da documentaça, auxilando no planejamento e no monitoramento das realizaçbes das professoras e das crianças

Esclareço que seräo preservadas as identidades das pesscas envolvidas no estudo $e$. tambem, da instituçao educacional como um todo. Ademas, os dados colhidos, seráo trahidos ao conhecimento pleno da insthucăo e das pessoas envolvidas no estudo e serăo empregados com finalidade exclusivamente acadèmica

Certa de poder contar com a valiosa colaboraçao de VSa, agradeçc antecipadamente

Cordialmente.

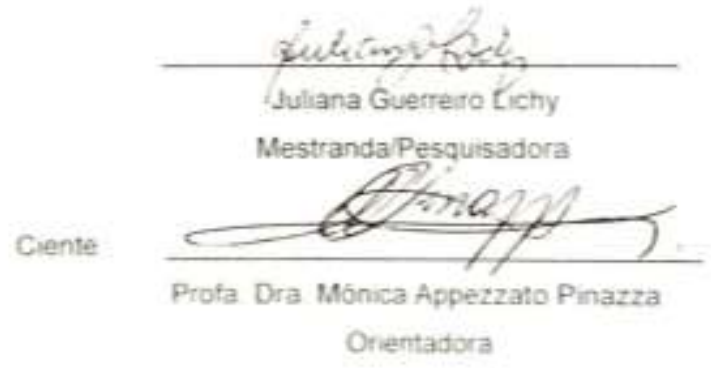

Assinatura de Aceite da Coordenadora Pedagógica.

Local e Data 
APÊNDICE E - Modelo de termo de consentimento livre e esclarecido enviado às educadoras

\section{TERMO DE CONSENTIMENTO LIVRE E ESCLARECIDO}

Concordo em participar, como voluntária, da pesquisa intitulada "A escuta do não falar: documentação pedagógica como reveladora dos bebês", que tem como pesquisador/a responsável Juliana Guerreiro Lichy, aluna da Faculdade de Educação da Universidade de São Paulo, orientada por Mônica Appezzato Pinazza, as quais podem ser contatados/as pelos emails juliana.lichy@yahoo.com.br / mapin@usp.br ou telefone XXXX-XXXX. O presente trabalho tem por objetivos: acompanhar a prática pedagógica das educadoras do grupo do berçário da instituição envolvida e as práticas de registro e documentação pedagógica que realizam. Minha participação consistirá em ser uma dessas educadoras disponibilizando à pesquisadora o acesso aos registros produzidos sobre o grupo de crianças envolvido e me dispondo a refletir em parceria sobre registros e documentação pedagógica. Compreendo que esse estudo possui finalidade de pesquisa, e que os dados obtidos serão divulgados seguindo as diretrizes éticas da pesquisa, assegurando, assim, minha privacidade. Sei que posso retirar meu consentimento quando eu quiser, e que não receberei nenhum pagamento por essa participação.

Nome:

Assinatura

Local e data 
APÊNDICE F - Modelo de autorização de uso de imagem das crianças

\section{TERMO DE CONSENTIMENTO LIVRE E ESCLARECIDO AOS PAIS E RESPONSÁVEIS PARA USO DE IMAGEM}

$\mathrm{Eu}$,

declaro saber da participação de meu/minha filho/a na pesquisa de mestrado "A escuta

do não falar: documentação pedagógica como reveladora dos bebês", desenvolvida junto à Faculdade de Educação da Universidade de São Paulo pela pesquisadora Juliana Guerreiro Lichy, orientada pela Prof ${ }^{\mathrm{a}}$. Dr ${ }^{\mathrm{a}}$. Mônica Appezzato Pinazza, as quais podem ser contatadas pelo e-mail juliana.lichy@yahoo.com.br ou telefone (11) XXXX-XXXX. O presente trabalho tem por objetivos: acompanhar a prática pedagógica das educadoras do grupo do berçário da instituição envolvida e as práticas de registro e documentação pedagógica que realizam. Os instrumentos utilizados são os registros das crianças que cursaram o Grupo Azul no ano de 2012 e podem envolver imagens. Permito e autorizo a utilização de imagem do/a meu/minha filho/a unicamente para esta pesquisa e compreendo que tenho liberdade de retirar o meu consentimento em qualquer fase da pesquisa, sem penalização alguma. A qualquer momento, posso buscar maiores esclarecimentos, inclusive relativos à metodologia do trabalho. A responsável pela pesquisa garante o sigilo, assegurando a privacidade dos sujeitos quanto aos dados envolvidos na pesquisa. Declaro compreender que as informações obtidas só podem ser usadas para fins científicos, de acordo com a ética na pesquisa, e que essa participação não inclui nenhum tipo de pagamento.

Data:

Assinatura:

Nome (em letra de forma):

Contato (email e/ou telefone): 
APÊNDICE G - Exemplos de diário de campo

\begin{tabular}{|c|c|}
\hline \multicolumn{2}{|r|}{ Nota de campo do dia 09 de junho de 2011 - acompanhamento da rotina } \\
\hline $13 \mathrm{~h} 45$ & $\begin{array}{l}\text { Chego na creche e vejo a exposição sobre o período de adaptação pronta. Haverá } \\
\text { reunião de pais - por isso a exposição. O título é “Brincadeiras de integração”. Há } \\
\text { relatos na exposição do berçário dos pais de alunos novos que contam da confiança } \\
\text { que tem na creche após acompanharem seus filhos na adaptação. }\end{array}$ \\
\hline $14 \mathrm{~h}$ & $\begin{array}{l}\text { Chego no momento dos ateliês. Hoje tem massinha, aquarela, brincadeira de casinha } \\
\text { e jogos de construção. Cumprimento as professoras. Encontro a coordenadora no } \\
\text { corredor ela me diz que hoje será um dia de planejamento reformulado por conta da } \\
\text { chuva. } \\
\text { Uma criança do Grupo Amarelo está chorando deitada no chão. A psicóloga da } \\
\text { creche tenta acalmá-la. }\end{array}$ \\
\hline $14 \mathrm{~h} 15$ & $\begin{array}{l}\text { Iara (uma criança) me vê e logo pede para ver os desenhos no meu caderno (na } \\
\text { semana anterior eu havia desenhado a seu pedido um pato, um peixe e uma ovelha } \\
\text { no final do meu caderno de campo). Ela se aproxima e diz: "Cadê o peixe?”. Eu } \\
\text { mostro, ela sorri, pede para eu desenhar mais bichos e eu atendo. Outras crianças se } \\
\text { interessam e se aproximam. Após um tempo, as professoras chamam para lavar as } \\
\text { mãos. }\end{array}$ \\
\hline $14 \mathrm{~h} 30$ & $\begin{array}{l}\text { Crianças tomam lanche como de costume: uns tomam mamadeira, outros tomam na } \\
\text { caneca. Um menino está no processo de transição entre a mamadeira e a caneca e } \\
\text { não consegue se decidir como tomará o leite. Pediu a mamadeira e a professora deu, } \\
\text { depois pediu a caneca e a professora também atendeu. Na caneca ele não tomou. A } \\
\text { professora oferece o canudo, ele aceita, mas não bebe. Então ela coloca um } \\
\text { pouquinho do leite na tampa da mamadeira. Ele gosta e bebe tudo! A professora } \\
\text { conta para que outro dia ela fez isso e ele gostou, então resolveu fazer de novo. Ela } \\
\text { esteve muito calma e paciente durante todo esse processo. } \\
\text { Isabela - uma criança que costuma gostar de estar ao meu lado - puxa a cadeira e } \\
\text { leva até mim. Senta-se e come seu biscoito ao meu lado. } \\
\text { *a psicóloga volta com a criança que estava chorando - ela parece bem mais calma } \\
\text { e traz um livro para mostrar à professora. }\end{array}$ \\
\hline $14 \mathrm{~h} 40$ & $\begin{array}{l}\text { Crianças vão para a escovação - como sempre ainda há alguns tomando lanche e } \\
\text { outros dormindo. }\end{array}$ \\
\hline
\end{tabular}




\begin{tabular}{|c|c|}
\hline & $\begin{array}{l}\text { Chove muito e por isso vamos para o pátio coberto. Lá, há algumas brincadeiras } \\
\text { propostas: carrinhos com bonecas, supermercado, blocos. } \\
\text { Converso com as educadoras que me contam sobre a festa junina da creche. Parece- } \\
\text { me ser muito valorizada por todos e uma festa bem agradável. }\end{array}$ \\
\hline $15 \mathrm{~h} 20$ & $\begin{array}{l}\text { Um menino brinca de jogar a bola por cima de um tapume de madeira que divide o } \\
\text { espaço do pátio em dois ambientes. Uma das professoras diz que não pode, mas } \\
\text { depois compreende a brincadeira e deixa que o menino continue. }\end{array}$ \\
\hline $15 \mathrm{~h} 40$ & $\begin{array}{l}\text { Estamos por uma hora no pátio e o grupo parece cansado de estar lá. Uma } \\
\text { professora saiu faz tempo- acho que foi organizar a próxima atividade. A professora } \\
\text { que está com o grupo começa a guardar os brinquedos. }\end{array}$ \\
\hline $15 \mathrm{~h} 55$ & $\begin{array}{l}\text { A prof. faz uma roda com as crianças para anunciar a próxima atividade. Diz que } \\
\text { terá uma ‘surpresa na salinha'. "Quem gosta de surpresa?” - ela pergunta. } \\
\text { O tempo de espera está um pouco maior que ela previa, então brinca de se esconder } \\
\text { em suas próprias mãos para as crianças acharem. Depois oferece água para todos } \\
\text { enquanto a outra professora não chama para a atividade. }\end{array}$ \\
\hline $16 \mathrm{~h}$ & $\begin{array}{l}\text { fim, a professora chega, mas diz que eles terão que ir para a sala de 'camaleão'- } \\
\text { na brincadeira que fazem para transitar de um espaço para outro. }\end{array}$ \\
\hline 16h05 & $\begin{array}{l}\text { Na sala há uma proposta de atividade que faz parte do projeto sobre Sensações. Há } \\
\text { dois varais e diversas garrafas pet pequenas penduradas. Nas garrafas há tinta, água } \\
\text { com gliter, água quente, água gelada. As crianças exploram cada uma e reverberam } \\
\text { as sensações sentidas: "tá gelado", “essa tá boa" - referindo-se à garrafa com água } \\
\text { quente. As crianças transitam, manuseiam as garrafas e levam-nas à boca. Tem } \\
\text { outro canto na sala com brinquedos para aqueles que se cansam das garrafas. As } \\
\text { crianças vão transitando por estes espaços e as professoras respeitam as escolhas de } \\
\text { cada um. } \\
\text { A mãe de uma criança chega para buscá-la - entra, cumprimenta todos, pega os } \\
\text { pertences da filha e vai. } \\
\text { As professoras interagem com as crianças durante suas explorações e uma delas } \\
\text { fotografa. }\end{array}$ \\
\hline $16 \mathrm{~h} 15$ & $\begin{array}{l}\text { Uma professora observa uma criança balançando uma garrafa e sugere a brincadeira } \\
\text { do "Balança caixão"- a criança gosta e outras a imitam. }\end{array}$ \\
\hline 16h20 & $\begin{array}{l}\text { Chega a mãe de outra criança que comenta a atividade. } \\
\text { Isabela pega uma garrafa e fica observando o gliter de dentro. Ela mostra para a }\end{array}$ \\
\hline
\end{tabular}




\begin{tabular}{|l|l|}
\hline & $\begin{array}{l}\text { professora e põe em sua bochecha para mostrar que está quente. Conforme a } \\
\text { professora senta-se no chão as crianças se aproximam. }\end{array}$ \\
\hline $16 \mathrm{~h} 30$ & $\begin{array}{l}\text { A atividade começa a se esgotar. As professoras vão calmamente organizando tudo. } \\
\text { Isabela insiste em ficar com uma garrafa e a professora deixa. }\end{array}$ \\
\hline $16 \mathrm{~h} 50$ & $\begin{array}{l}\text { As professoras começam a preparar as crianças para o jantar colocando os } \\
\text { babadores. } \\
\text { Vou com eles até a sala onde será servido o jantar, me despeço e vou embora. As } \\
\text { crianças acenam, dizem 'tchau' para mim, como de costume. }\end{array}$ \\
\hline
\end{tabular}

\section{Nota de campo do dia 08 de junho de 2012 - observações do material da creche (registros)}

Hoje, após conversa com a coordenadroa comecei a ler o Relatório de Grupo Azul do ano de 2011. É um material extenso com 36 páginas, elaborado pelas 6 educadoras do grupo e que envolve todas as atividades desenvolvidas ao longo do ano. Esse relatório é enviado às famílias, composto por texto e algumas imagens. O início relata a sistematização da rotina e o período de adaptação. A seguir, tem um subtítulo "Trabalho Pedagógico no Grupo Azul", seguido de um texto que pareceu interessante:

"Elaborar o trabalho pedagógico para as crianças bem pequenas envolve escuta e olhar sensível dos educadores da creche que fazem parte do grupo azul. É preciso observar atentamente o que as crianças dizem através de seus olhares, sons, gestos e brincadeiras com o desafio de participar dessa comunicação que ocorre numa dimensão não verbal das relações.

O corpo da criança fala, ela consegue demonstrar seus interesses em todos os momentos da rotina e, para que esse momento seja percebido, precisamos estar atentas a todo o momento, para acolher o que chama a atenção dos bebês e transformar em um conjunto de experiências significativas da Creche.

A Creche desenvolve algumas modalidades organizativas no que diz respeito ao trabalho pedagógico. Uma delas, denominamos "Sequencia de Atividades", que consiste em traduzir as dicas das crianças sistematizandoas em uma sequencia de atividades que propõem experiências com objetivos pré-definidos. Durante o ano, podemos ter diversas sequencias de atividades com temáticas diferentes, e a duração dessas sequências depende 
do envolvimento do grupo.

Também trabalhamos com "Projeto de Trabalho", que consiste em um estudo aprofundado que se desenvolve coletivamente sobre um determinado tema. É uma organização de propostas mais estruturadas, baseadas em eixos ou temáticas de interesse das crianças. Dessa forma, nos projetos de trabalho, não há a preocupação com um produto final, mas sim com as conexões e vivências que serão construídas pelas crianças ao longo do percurso." (O trabalho pedagógico do Azul)

Conversamos bastante hoje sobre os planejamentos das educadoras. A coordenadora me contou que atualmente o Grupo Azul está com 4 crianças e até meados de abril ainda receberá crianças ingressantes. Durante esse período as educadoras trabalham com uma "ficha de observação", registrando o processo de adaptação de cada criança. Segundo ela, é fundamental este olhar no começo do ano, pois são eles que sugerem o desenvolvimento do trabalho ao longo do ano. Na creche é recorrente o uso da palavra 'dica'. Frequentemente elas citam as dicas das crianças. Segundo a coordenadora, as dicas são aquilo que o educador lê nos gestos dos bebês, valendo-se dessa escuta para planejar suas ações.

Após essa colheita de dados nas fichas de observação, as educadoras buscam um foco de atuação, chamado de "Organização inicial do projeto" - um tema gerador onde se desencadearão propostas diversas nas diferentes áreas. Uma vez definido esse tema, as educadoras passam a trabalhar com as "Fichas de Planejamento". Tais fichas compreendem etapas a serem desenvolvidas com as crianças envolvendo o planejamento inicial (aquilo que a educadora prevê) e o planejamento recriado (planejamento revisto a partir dos registros, avaliações, dicas das crianças). Conforme a coordenadora descreveu, o preenchimento dessas fichas parece traduzir uma prática de movimento no planejamento das educadoras. A própria coordenadora sugeriu que eu entrevistasse as educadoras para ouvir delas como é essa vivência do planejamento.

Irei à creche na próxima $5 \mathrm{f}$ para continuar analisando os materiais produzidos pelas educadoras. Está previsto para dia 19/03 uma reunião com as 6 educadoras do Grupo Azul para eu me apresentar e apresentar a pesquisa. A partir daí, minha ação será como uma outra voz de articulação sobre a prática com as crianças e a produção das documentações. 
ANEXO A - Exemplo da ficha de planejamento da creche
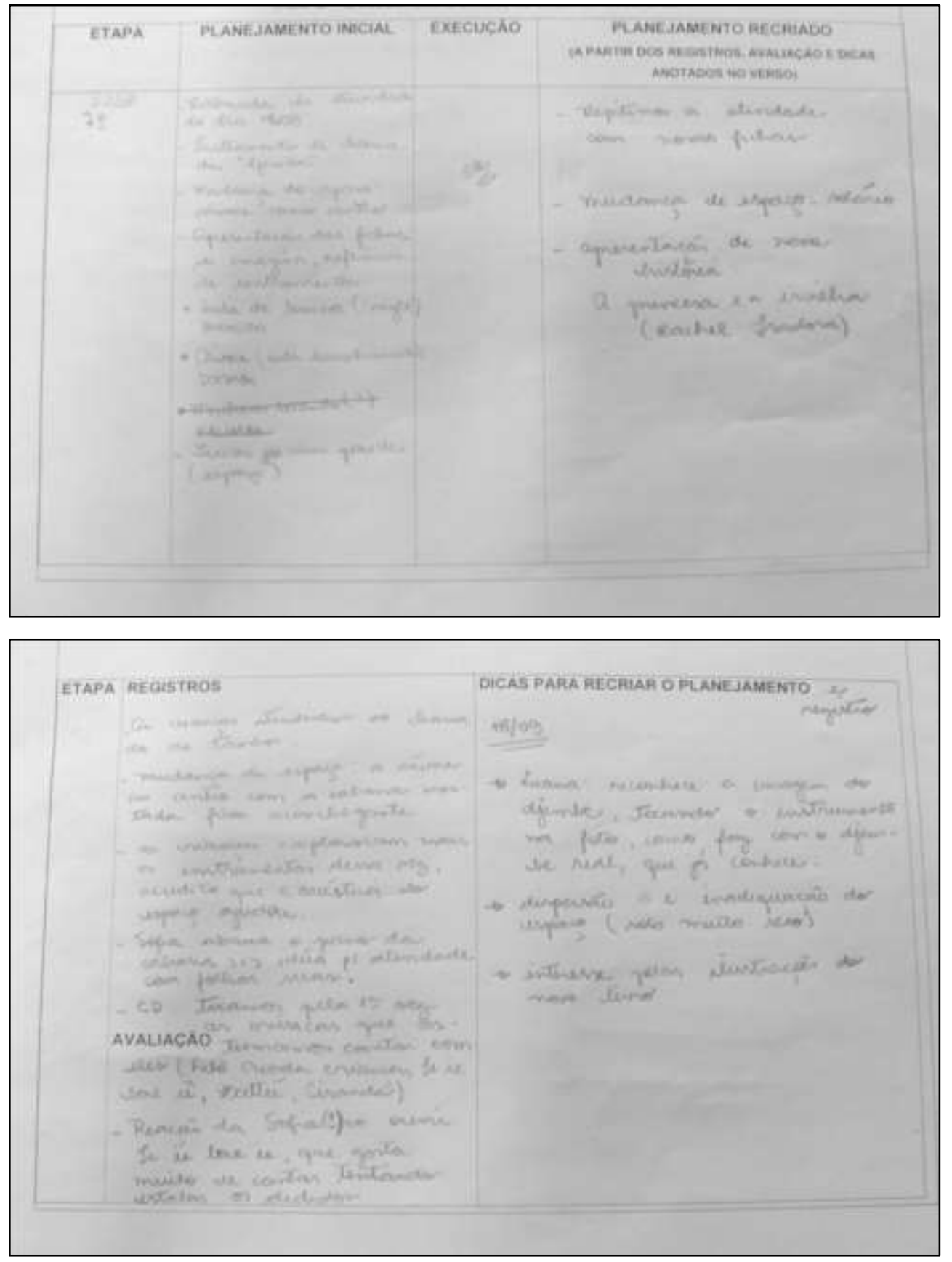
ANEXO B - Transcrição dos planejamentos do Grupo Azul do ano de 2012

Capa

\begin{tabular}{|c|c|}
\hline \multicolumn{2}{|r|}{ Capa } \\
\hline Capa: & Pasta de papel com plásticos. Capa decorada com tecidos de chita \\
\hline \multicolumn{2}{|r|}{ Folha 1} \\
\hline Título do projeto: & A definir \\
\hline Educadores: & $\mathrm{L}, \mathrm{M}$ e $\mathrm{S}$ \\
\hline Grupo: & Azul-tarde \\
\hline \multicolumn{2}{|r|}{ Folha 2} \\
\hline Justificativa: & Em branco \\
\hline Objetivos: & Em branco \\
\hline \multicolumn{2}{|r|}{ Folha 3} \\
\hline $\begin{array}{l}\text { Levantamento dos } \\
\text { conhecimentos } \\
\text { prévios }\end{array}$ & $\begin{array}{l}\text { Observação dos interesses dos pequenos: } \\
\text { *Movimento: há uma exploração muito intensa ao redor do móvel, } \\
\text { passando por dentro, brincando de esconder, experimentando } \\
\text { possibilidades mais ousadas (de alturas 'perigosas' para eles, mas ao } \\
\text { nosso alerta voltam e experimentam de novo, tentam se equilibrar). A } \\
\text { dança acontece ao ritmo das músicas, acompanham se remexendo, } \\
\text { demonstrando compreensão das letras, ex: pintinho amarelinho } \\
\text { (mostram apontando o indicador na palma da mão). } \\
\text { *Ritmos: marcando através da percussão, corpo e objetos, palmas, } \\
\text { pedacinhos de madeira, objetos, brinquedos, brinquedos sonoros. } \\
\text { *Histórias: lemos com aparatos sonoros; os de textura experimentam } \\
\text { com os dedos, observando, ouvindo as narrações. } \\
\text { *Curiosidades: menores brincam com as mãos, exploram os } \\
\text { brinquedos pequenos; maiores observam o corpo do outro levantando } \\
\text { as camisetas, querem tocar na pele, cutucar o umbigo } \\
\text { ‘experimentando' o outro (amigos e educadoras), observar o rosto, } \\
\text { olhar nos olhos, beijar, abraçar. } \\
\text { *Meio Ambiente: os pequenos sabem quem são os peixes. Ao } \\
\text { perguntarmos se movimentam em direção ao aquário e apontam os } \\
\text { peixinhos. }\end{array}$ \\
\hline \multicolumn{2}{|r|}{ Folha 4} \\
\hline Mapa da & Organização do Projeto \\
\hline
\end{tabular}




\begin{tabular}{|c|c|}
\hline $\begin{array}{l}\text { Organização do } \\
\text { Projeto }\end{array}$ & $\begin{array}{l}\text { CORPO: exploração dos sentidos: ouvir, falar, tocar, sentir. } \\
\text { ARTES: ilustração de livros, tecidos, cores. } \\
\text { LINGUAGEM ORAL E ESCRITA: histórias contextualizadas nos } \\
\text { sentidos } \\
\text { MOVIMENTO: brincadeiras dançantes, ritmo, equilíbrio, dança. } \\
\text { MÚSICA: movimento e ritmo (descobertas gerais e percussão } \\
\text { corporal, sonoridade com diferentes materiais). } \\
\text { BRINCADEIRAS: experimentação de si e do outro }\end{array}$ \\
\hline \multicolumn{2}{|r|}{ Folha 5} \\
\hline $\begin{array}{l}\text { Pauta de } \\
\text { observação para } \\
\text { início dos projetos }\end{array}$ & Em branco \\
\hline \multicolumn{2}{|r|}{ Folha 6} \\
\hline \multirow{7}{*}{ Planejamento 1} & Etapa: $1^{a}$ \\
\hline & $\begin{array}{l}\text { Planejamento inicial: apresentação do livro "Obax" - texto e } \\
\text { ilustrações de André Neves } \\
\text { Roda de história - narrar e apresentar o livro, deixar que explorem } \\
\text { Papel cartão - negro, laranja, vermelho. Compor com “flores" de } \\
\text { chita (observadas no lixo) com giz pastel }\end{array}$ \\
\hline & Execução: ok \\
\hline & $\begin{array}{l}\text { Registros: as crianças aproveitaram bastante a história, no chamado, } \\
\text { na história, os maiores vêm engatinhando e vão se acomodando e } \\
\text { prestando bastante atenção aos detalhes, sons e músicas. }\end{array}$ \\
\hline & Avaliação: em branco \\
\hline & $\begin{array}{l}\text { Dicas para recriar o planejamento: contar a história novamente, } \\
\text { compor com mais elementos musicais e gráficos. }\end{array}$ \\
\hline & $\begin{array}{l}\text { Planejamento recriado: papel cartão - giz de lousa molhado } \\
\text { Papel picado (crepom) } \\
\text { Chuva sobre as crianças } \\
\text { Instrumentos musicais }\end{array}$ \\
\hline \multicolumn{2}{|r|}{ Folha 7} \\
\hline \multirow[b]{2}{*}{ Planejamento 2} & Etapa: $2^{a}$ \\
\hline & Planejamento inicial: organização do espaço com tecidos, tapete e \\
\hline
\end{tabular}




\begin{tabular}{|c|c|}
\hline & $\begin{array}{l}\text { almofadas. } \\
\text { Roda de história sobre a árvore } \\
\text { Reapresentar o livro "Obax" e compor com instrumentos para os } \\
\text { efeitos sonoros } \\
\text { Chuva de papel crepom picado (flores caindo do céu) } \\
\text { Oferecer papel carão e giz de lousa molhado }\end{array}$ \\
\hline & Execução: ok \\
\hline & $\begin{array}{l}\text { Registros: as crianças se apropriaram ainda mais dos elementos } \\
\text { apresentados, enquanto ouviam a história brincavam explorando os } \\
\text { instrumentos e se animaram com a chuva de papel picado. }\end{array}$ \\
\hline & Avaliação: em branco \\
\hline & $\begin{array}{l}\text { Dicas para recriar o planejamento: exploram bastante os papéis } \\
\text { (pegam, olham, levam à boca). } \\
\text { Materiais gráficos também muito levados à boca, melhor investir em } \\
\text { elementos naturais (leite - muito explorado). } \\
\text { Folhas que estão espalhadas pela grama e nosso pequeno pátio } \\
\text { Instrumentos muito explorados (investir em composição dos mesmos) } \\
\text { *Família (apego) }\end{array}$ \\
\hline & Planejamento recriado: em branco \\
\hline & Folha 8 \\
\hline & Etapa: $3^{a}$ \\
\hline Planejamento 3 & $\begin{array}{l}\text { Planejamento inicial: organização do espaço com tecidos, tapete, } \\
\text { etc... } \\
\text { Roda de história: na casinha, reapresentar os instrumentos, recontar a } \\
\text { história "Obax" } \\
\text { Reapresentar o papel cartão anteriormente explorado por eles com } \\
\text { mais um elemento plástico (giz pastel) }\end{array}$ \\
\hline & Execução: ok \\
\hline & $\begin{array}{l}\text { Registros: as crianças se aproximam com rapidez do material } \\
\text { oferecido. Os instrumentos são bastante apropriados, o livro é } \\
\text { procurado por todos, que ficam em roda por quanto tempo ele estiver } \\
\text { sendo contado e recontado. Os materiais plásticos (montados na } \\
\text { lateral da roda) vão sendo encontrados após a roda, um a um, vão }\end{array}$ \\
\hline
\end{tabular}




\begin{tabular}{|c|c|}
\hline & $\begin{array}{l}\text { chegando, experimentando e deixando suas marcas. Há momentos de } \\
\text { exploração onde os pequenos tocam uns aos outros e acabam } \\
\text { exagerando, puxando os cabelos... }\end{array}$ \\
\hline & Avaliação: em branco \\
\hline & $\begin{array}{l}\text { Dicas para recriar o planejamento: apresentar fichas com obras de } \\
\text { artistas que apresentam pessoas e instrumentos, famílias e atrás das } \\
\text { imagens, as músicas do interesse deles digitadas. } \\
\text { Obras: "Tocador de pífaro" de Èdouard Manet e "Mãe camponesa" } \\
\text { de David Alfaro Siqueiros } \\
\text { Músicas "Tá caindo fulô" } \\
\text { Produzir um quadro tátil } \\
\text { Apresentar novos livros, três de Eliardo França e Mary França: } \\
\text { "O aniversário" } \\
\text { "Atchim!" } \\
\text { "Buá, buá... o que será". } \\
\text { Oferecer sempre os instrumentos e ? }\end{array}$ \\
\hline & Planejamento recriado: em branco \\
\hline & Folha 9 \\
\hline & Etapa: $4^{\text {a }}$ \\
\hline Planejamento 4 & $\begin{array}{l}\text { Planejamento inicial: } 1^{a} \text { atividade de agosto } \\
\text { Clarice Lispector } \\
\text { "Lembrar com saudade é viver novamente" } \\
\text { - organização do espaço com tecidos, uma caixa com os variados } \\
\text { elementos que compuseram o } 1^{\circ} \text { semestre, tecidos, toquinhos, } \\
\text { instrumentos: chocalho de cabaça, de cetro de cabra, caxixi, livros, } \\
\text { papel crepom e celofane. Tambor: djembe, kalimba. } \\
\text { Deixar que explorem e recordem }\end{array}$ \\
\hline & Execução: ok 01/08/2012 \\
\hline & Registros: em branco \\
\hline & Avaliação: em branco \\
\hline & Dicas para recriar o planejamento: em branco \\
\hline & $\begin{array}{l}\text { Planejamento recriado: REGISTRO } \\
\text { - as crianças se apropriaram dos materiais e demonstraram que já }\end{array}$ \\
\hline
\end{tabular}




\begin{tabular}{|c|c|}
\hline & $\begin{array}{l}\text { conheciam alguns dos materiais e as maneiras como podiam utilizá- } \\
\text { los } \\
\text { - papel celofane: além, do elemento sonoro, possibilitou brincadeiras } \\
\text { de esconder e ideias sobre a visualidade e as cores. } \\
\text { - o djembe: por ser o maior dos instrumentos apresentados, foi } \\
\text { bastante requisitado, as crianças já demostram reconhecer em qual } \\
\text { parte o som é extraído (no caso o couro). } \\
\text { - as crianças reconhecem as músicas, participando da cantoria com } \\
\text { gesto ou manipulando os objetos sonoros. } \\
\text { - a atividade foi mais livre, as crianças puderam explorar os materiais } \\
\text { com liberdade. }\end{array}$ \\
\hline \multicolumn{2}{|r|}{ Folha 10} \\
\hline \multirow{7}{*}{ Planejamento 5} & Etapa: $5^{\text {a }}$ \\
\hline & $\begin{array}{l}\text { Planejamento inicial: apresentar às crianças as fichas de imagens e } \\
\text { de música: "mãe camponesa" de David Alfaro Siqueiros e "Tocador } \\
\text { de pífaro" } \\
\text { Músicas "Caindo fulô", "Battú"; Guantanamera; } \\
\text { *No espaço externo organizar material: papel cartão e areia - deixar } \\
\text { que explorem. }\end{array}$ \\
\hline & Execução: ok \\
\hline & $\begin{array}{l}\text { Registros: areia úmida dificultou os desenhos das crianças; crianças } \\
\text { assumiram o processo, gostaram mais de transportar e explorar a } \\
\text { areia do que aproveitar a possibilidade do desenho; pequenos: } \\
\text { exploração dos instrumentos musicais, conhecer a areia; Sofia: } \\
\text { marcas dos pés na areia - pés coloridos. }\end{array}$ \\
\hline & Avaliação: em branco \\
\hline & $\begin{array}{l}\text { Dicas para recriar o planejamento: propor a mesma atividade, mas } \\
\text { sem montar o espaço, montar o espaço com as crianças. }\end{array}$ \\
\hline & Planejamento recriado: em branco \\
\hline \multicolumn{2}{|r|}{ Folha 11} \\
\hline \multirow[b]{2}{*}{ Planejamento 6} & Etapa: $6^{a}$ \\
\hline & $\begin{array}{l}\text { Planejamento inicial: reapresentar os elementos da atividade } \\
\text { anterior }\end{array}$ \\
\hline
\end{tabular}




\begin{tabular}{|c|c|}
\hline & $\begin{array}{l}\text { Ênfase nas músicas "Battú" e "Guantanamera"; aproximações entre } \\
\text { África e América - musicalidades. } \\
\text { Atividade com areia - desenho corporal na areia, montagem do } \\
\text { espaço junto com as crianças. } \\
\text { Roda de histórias + instrumentos musicais (Novo instrumento: } \\
\text { Kalimba) }\end{array}$ \\
\hline & Execução: ok 15/08/2012 \\
\hline & $\begin{array}{l}\text { Registros: as crianças foram convidadas com música - Silvana } \\
\text { tocando Kalimba. Na casinha os maiores foram entrando indo ao } \\
\text { encontro da Silvana, alguns mexendo nos instrumentos. Os menores } \\
\text { engatinhando. } \\
\text { Luana: quando percebeu o novo instrumento observou e depois } \\
\text { correu para pegar um instrumento que já conhecia (caxixi) para tocar } \\
\text { junto. } \\
\text { Parede de tecido serviu para brincadeira com o corpo (esconder e } \\
\text { tocar o outro através do tecido) e brincadeiras sonoras (produção de } \\
\text { sons escondidos) }\end{array}$ \\
\hline & $\begin{array}{l}\text { Avaliação: foi lindo, as crianças participaram conosco até o jantar e } \\
\text { os instrumentos permaneceram mais tempo disponíveis }\end{array}$ \\
\hline & Dicas para recriar o planejamento: em branco \\
\hline & $\begin{array}{l}\text { Planejamento recriado: repetir atividade no espaço da casinha } \\
(22 / 08) \\
\text { Brincadeira de esconde-esconde no tecido (Luana) }\end{array}$ \\
\hline & Folha 12 \\
\hline & Etapa: $7^{\mathrm{a}}$ \\
\hline Planejamento 7 & $\begin{array}{l}\text { Planejamento inicial: retomada da atividade do dia 15/08 } \\
\text { Instrumento de chamada "djembe" } \\
\text { Mudança do espaço: árvore como centro } \\
\text { Apresentação das fichas de imagens, referência de instrumentos } \\
\text { - Roda de samba (carybé) pandeiro } \\
\text { - Árvore (autor desconhecido)djembe } \\
\text { - Tecido como parede (espaço) }\end{array}$ \\
\hline & Execução: ok \\
\hline
\end{tabular}




\begin{tabular}{|c|c|}
\hline & $\begin{array}{l}\text { Registros: as crianças atenderam ao chamado do tambor } \\
\text { Mudança de espaço: a árvore ao centro com a cabana montada ficou } \\
\text { muito aconchegante } \\
\text { As crianças exploraram mais os instrumentos, dessa vez acredito que } \\
\text { a acústica do espaço ajudou. } \\
\text { Sofia abana o pano da cabana - ideia para atividade com folhas secas } \\
\text { CD: tocamos pela primeira vez as músicas que costumamos cantar } \\
\text { com eles (Fulô, Acorda crianças, ie, ie, eae, ie, Battú, Ciranda) } \\
\text { Reação da Sofia ao ouvir Ie, ie... que gosta muito de cantar tentando } \\
\text { estalar os dedinhos... }\end{array}$ \\
\hline & Avaliação: \\
\hline & $\begin{array}{l}\text { Dicas para recriar o planejamento: } \\
\text { Luana: reconhece a imagem do Djembe tocando o instrumento na } \\
\text { foto como faz com o djembe real que já conhece. } \\
\text { Dispersão e inadequação do espaço (solo muito seco) } \\
\text { Interesse pelas ilustrações do novo livro }\end{array}$ \\
\hline & $\begin{array}{l}\text { Planejamento recriado: repetirmos a atividade com novas fichas } \\
\text { Mudança de espaço: solário } \\
\text { Apresentação de nova história: “A princesa e a ervilha” - Rachel } \\
\text { Isadora }\end{array}$ \\
\hline \multicolumn{2}{|r|}{ Folha 13} \\
\hline \multirow{5}{*}{ Planejamento 8} & Etapa: $8^{a}$ \\
\hline & 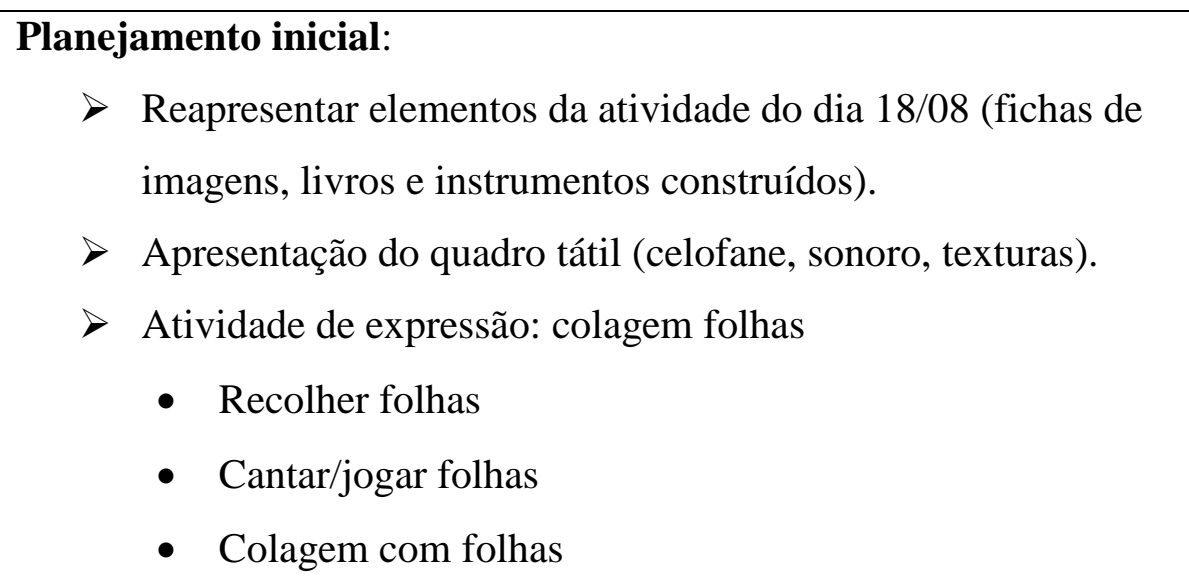 \\
\hline & Execução: 19/08 ok \\
\hline & Registros: em branco \\
\hline & Avaliação: em branco \\
\hline
\end{tabular}




\begin{tabular}{|c|c|}
\hline & Dicas para recriar o planejamento: em branco \\
\hline & $\begin{array}{l}\text { Planejamento recriado: as crianças exploraram o quadro sentindo as } \\
\text { texturas (lixa), brincaram com o celofane produzindo sons. } \\
\text { A colagem com folhas: colocamos o papel colado no chão. Algumas } \\
\text { crianças passaram as mãos melecando-as na cola. Luana demonstrou } \\
\text { gostar dessa atividade, ficou tirando a cola seca da mão bem } \\
\text { concentrada. } \\
\text { Cola no chão e no papel - as crianças escorregaram }\end{array}$ \\
\hline & Folha 14 \\
\hline & Etapa: $9^{a}$ \\
\hline Planejamento 9 & $\begin{array}{l}\text { Planejamento inicial: montar apresentação das fichas: } \\
\text { - Imagem djembe/ foto djembe / crianças tocando djembe } \\
\text { - Imagem pandeiro / xequerê e fotos das crianças com o } \\
\text { pandeiro/xequerê } \\
\text { - Imagem da kalimba / foto kalimba / crianças tocando kalimba } \\
\text { - Imagem do ganzá / foto crianças tocando } \\
\text { Músicas para reapresentação de cada instrumento }\end{array}$ \\
\hline & Execução: ok \\
\hline & $\begin{array}{l}\text { Registros: reapresentar as fotos, agora penduradas no bambolê com } \\
\text { vários instrumentos que produzem sons: caixas de leite, caixa de } \\
\text { creme dental, potes, chocalhos de chaves e tampinhas. }\end{array}$ \\
\hline & Avaliação: em branco \\
\hline & $\begin{array}{l}\text { Dicas para recriar o planejamento: crianças se interessaram pelos } \\
\text { tecidos amarrando-os na cabeça - ideia de oferecer chapéus no estilo } \\
\text { de turcos ou turbantes. }\end{array}$ \\
\hline & $\begin{array}{l}\text { Planejamento recriado: as crianças gostaram muito do clima da } \\
\text { atividade, pegaram as fotos, ficaram se olhando e olhando os colegas, } \\
\text { também participaram da roda de música tocando os vários } \\
\text { instrumentos oferecidos. Essa atividade foi realizada no pátio da } \\
\text { árvore, repetiremos outras vezes. }\end{array}$ \\
\hline & Folha 15 \\
\hline & Etapa: $10^{\mathrm{a}}$ \\
\hline Planejamento 10 & Planejamento inicial: reapresentar as fotos na casinha penduradas no \\
\hline
\end{tabular}




\begin{tabular}{|c|c|}
\hline & $\begin{array}{l}\text { bambolê com alguns instrumentos construídos com caixas, potes, } \\
\text { chaves, tampinhas e móbiles de chaves. } \\
\text { Fichas de músicas e instrumentos da caixa } \\
\text { Djembe } \\
\text { Novidade: saquinhos com elementos olfativos (canela, cravo, } \\
\text { orégano, louro, sachê de morango). }\end{array}$ \\
\hline & Execução: ok \\
\hline & Registros: em branco \\
\hline & Avaliação: em branco \\
\hline & $\begin{array}{l}\text { Dicas para recriar o planejamento: mudar de lugar o móbile } \\
\text { gigante; criar no mesmo molde outros móbiles (só materiais sonoros, } \\
\text { só materiais olfativos, só fotos, só materiais naturais - folhas e } \\
\text { flores). }\end{array}$ \\
\hline & $\begin{array}{l}\text { Planejamento recriado: como o material ficou na sala as crianças } \\
\text { tem explorado de formas variadas, inclusive brincando de empurrar o } \\
\text { bambolê, de se esconder atrás das fotos, de passar por baixo. }\end{array}$ \\
\hline & Folha 16 \\
\hline & Etapa: $11^{\mathrm{a}}$ \\
\hline Planejamento 11 & $\begin{array}{l}\text { Planejamento inicial: dica: ao longo das atividades oferecemos } \\
\text { como parte do material tecidos diversos - alguns com estampas, } \\
\text { chitas e vual. } \\
\text { Imprimimos as imagens dos livros, as crianças apontaram para (?), } \\
\text { colocaram as imagens na cabeça, além de brincarem de esconder. } \\
\text { Oferecemos então chapéus que lembrem turcos/turbantes, mas } \\
\text { brincaram de colocar e tirar, além de brincar com outros chapéus, } \\
\text { instrumentos e músicas do projeto. }\end{array}$ \\
\hline & Execução: ok \\
\hline & $\begin{array}{l}\text { Registros: as crianças se interessaram pelos chapéus, olhavam-se no } \\
\text { espelho e demonstravam a necessidade de se relacionar com o corpo } \\
\text { do outro - colocam e tiram o chapéu uns nos outros. Colocam } \\
\text { também os chapéus nas educadoras. }\end{array}$ \\
\hline & Avaliação: em branco \\
\hline & Dicas para recriar o planejamento: trazer imagens de pessoas \\
\hline
\end{tabular}




\begin{tabular}{|c|c|}
\hline & ornamentadas com toucas/turbantes \\
\hline & Planejamento recriado: em branco \\
\hline & Folha 17 \\
\hline & Etapa: $12^{\mathrm{a}}$ \\
\hline Planejamento 12 & $\begin{array}{l}\text { Planejamento inicial: cabelos de Obax: } \\
\text { - cabelos de lã } \\
\text { - quadro tátil em tecidos - pintura }\end{array}$ \\
\hline & Execução: em branco \\
\hline & Registros: em branco \\
\hline & Avaliação: em branco \\
\hline & Dicas para recriar o planejamento: em branco \\
\hline & Planejamento recriado: em branco \\
\hline
\end{tabular}


ANEXO C - Transcrição do Projeto "Ritmos Coloridos" - Grupo Azul 2012

\author{
RITMOS COLORIDOS: \\ O Grupo Azul em Sons e Cores \\ S.J \\ Ai, presta atenção, menina \\ Por onde vai passar \\ Aqui vou desenhar a linha por onde eu passei \\ E não vou esperar o dia amanhecer \\ O dia amanheceu, aí eu me levantei \\ E não me lembrava onde ficava \\ A linha que desenhei
}

E foi assim como uma linha desenhada a cada dia que se desenrolou o projeto das tardes do Grupo Azul em 2012.

Tudo começou nas brincadeiras que apareceram ainda no período de adaptação das crianças... Surgiram as brincadeiras cantadas e dentre elas uma canção:

2. J

Tá caindo fulô, tá caindo fulô

Lá do céu, cá na terra

Olelê tá caindo fulô

ร.J

E a canção puxou a linha da história de um livro chamado "Obax" que conta de uma menina que viu, certa vez, uma chuva de flores. A apresentação do livro para as crianças trouxe novos elementos para serem explorados: a história se passa na África e as imagens trazem cores e estampas que chamam bastante a atenção dos pequenos. Unindo tais elementos ao interesse que as crianças já demonstravam pelas músicas e as brincadeiras rítmicas, organizamos novas e variadas formas de contar essa história ao longo do semestre.

Da primeira vez, o espaço foi organizado embaixo da árvore, no lado de fora da Casinha, com almofadas; tecido com estampas africanas; uma chuva de flores (feitas de papel crepom picado) e um instrumento africano, um tambor, chamado djembe para acompanhar a cantoria. Também colocamos outros brinquedos e objetos 
sonoros (chocalho de cabaça, chocalho de unhas de cabra, caxixi, ovo percussivo, entre outros). Depois dessa contação, oferecemos ainda giz pastel colorido para a exploração das cores sobre papel preto.

As crianças foram tomadas por uma espécie de encantamento pelo djembe. Exploraram o instrumento para conhecê-lo e tentamos mostrar às crianças as possibilidades sonoras, cantando algumas músicas conhecidas. E foi esse interesse tão bonito das crianças pelo tambor que nos fez pensar que a linha que estávamos desenhando junto com eles podia levar para o caminho dos ritmos, dos sons, das cores.

E assim, pensamos que a cada novo interesse dos pequenos, podíamos trazer uma música relacionada, um novo instrumento e outras possibilidades de exploração para o momento em que nos reuníssemos para partilhar nossos ritmos.

Começamos a observar, então, o aumento do interesse das crianças pelas fotos do quadro das famílias. Uma exploração que era aparentemente indefinida passa a ser direcionada para encontrar a imagem da própria família e o reconhecimento dos pais. Algumas crianças, que começavam a se arriscar na produção de suas primeiras palavras, apontavam a "mamã”, o "papá”... Será que teríamos uma música que pudesse nos embalar nesse momento de saudade?

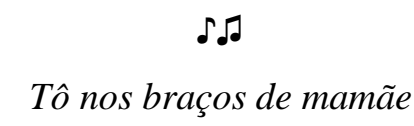

Pra ela me acarinhar

Apareça valentão

Para me tirar de lá

- Nos braços dela eu vou morar

\section{ร.J}

Partindo de uma imagem do livro "Obax", em que a personagem abraça sua mãe, apresentamos essa música para as crianças. De início, algumas crianças choraram ao ouvi-la, porque pareciam ainda não lidar muito bem com a despedida da família e a palavra "mamãe" ainda despertava um sentimento de saudade quando pronunciada. Mas logo a música passou a representar um conforto, virou uma brincadeira que envolveu instrumentos e passos de dança. A saudade ficou colorida e mais bonita.

Foi nesse movimento que as crianças do Grupo Azul começaram a demonstrar a construção de uma compreensão do que significa esse momento de 
grupo, em que fazíamos coisas juntos, onde histórias, músicas, instrumentos e materiais variados eram apresentados e explorados e o movimento das crianças começou a se organizar no sentido de uma participação curiosa.

$\mathrm{Na}$ volta das férias, no começo do mês de agosto, organizamos uma atividade livre, para que os pequenos pudessem rever os materiais que já conheciam, ouvir as nossas músicas e refazer nossas 'coreografias' com palmas e dança, além de tocar os nossos instrumentos... Novos elementos apareceram com destaque. Nessa atividade, a atenção se volta para o papel celofane, que além das possibilidades sonoras, possibilitou as brincadeiras de esconder, tantas vezes repetidas com alegria pelas crianças. O papel celofane tornou mais colorido o ambiente e as brincadeiras.

No retorno das férias ficou mais evidente também o interesse das crianças pelos materiais facilmente encontrados no espaço da Creche: a areia, as folhas e flores dispensadas pelas árvores no outono.

Assim nossas atividades do projeto acompanham esse interesse das crianças... Cantando sempre:

$$
\begin{gathered}
\text { S.J } \\
\text { No mar tem areia - Areia } \\
\text { Areia no mar-Areia } \\
\text { Que areia boa - Areia } \\
\text { Pra gente peneirar - Areia } \\
\text { Quando eu pensava que era um - Era um babado só } \\
\text { Quando eu pensava que eram dois - Era um babado só } \\
\text { Quando eu pensava que eram três - Era um babado só... } \\
\text { S.ঠ }
\end{gathered}
$$

Apresentamos, então, as novas músicas para os pequenos utilizando os instrumentos que eles já estavam acostumados a tocar e explorar, junto com a brincadeira na areia com baldes e peneiras. Foi interessante como rapidamente as crianças transformaram os baldes em tambores (virando-os com o fundo para cima) para acompanhar o ritmo das músicas.

A atividade que propusemos em seguida, na verdade, refletia uma brincadeira que as próprias crianças criaram e que consistia em carregar a areia de várias formas (com as mãos, em baldes, em pequenas panelas de brinquedo, em potes variados) e espalhar em outro lugar.

Certa vez, espalharam a areia sobre uma placa de EVA colorida e descobrir 
a cor por baixo da areia foi encantador para as crianças. Assim, organizamos a atividade colocando papéis coloridos no chão e cobrindo-os de areia para que as crianças pudessem descobrir cores variadas e explorar ainda mais a areia. Para esse desenho corporal sobre a areia as crianças usaram as mãos e os pés, gerando pegadas, testaram as possibilidades de desenhar com alguns brinquedos e recolheram gravetos do próprio espaço que funcionaram quase como lápis! E o Grupo Azul foi ficando cada vez mais colorido...

$\mathrm{O}$ crescente interesse das crianças pelas sonoridades e pelos instrumentos/brinquedos musicais que fomos construindo para e com elas ao longo do ano inspirou-nos a apresentar aos pequenos um novo instrumento: a kalimba. Trata-se de um outro instrumento africano (assim como o djembe), que dialoga, portanto, com a paisagem africana da história da "Obax" e com as estampas trazidas para a ambientação do espaço durante nossas atividades. E já que, de repente, se formou um contexto de África no Grupo Azul, aproveitamos para apresentar nova canção, dessa vez africana, do Benin, reproduzida em $\mathrm{CD}^{16}$ :

\section{ร.J}

Yia yia yie ea aaahh

Yia yia yie ea aaahh

Battú, battú, battú

\section{ร.J}

Essa se tornou uma das músicas prediletas das crianças do Grupo Azul à tarde! Algumas vezes dançávamos essa canção usando tornozeleiras com guizos ou sementes o que tornava a dança bastante divertida.

A atividade com a kalimba nos apresentou uma nova possibilidade: instigar a percepção auditiva das crianças. Criamos uma parede com tecido dentro da Casinha e a kalimba foi tocada atrás dessa parede. Aos poucos, as crianças que estavam do lado de fora da Casinha percebem o novo som e foram entrando curiosas para descobrir a origem desse som. Ao entrar e perceber que a kalimba estava sendo tocada, ao invés de buscar o próprio instrumento, as crianças começaram a pegar os outros instrumentos que deixamos disponíveis e começaram a tocar junto. Nessa atividade, foi possível perceber, então, que as crianças começavam a se apropriar da ideia de "composição rítmica", fruto talvez das nossas experiências em que

\footnotetext{
${ }^{16}$ Faixa 01. Battú, de Angelique Kidjo (Benin) - CD ‘African Playground’ - Putumayo Kids.
} 
distribuíamos instrumentos variados para as crianças enquanto cantávamos, transformando esses momentos em momentos compartilhados de construção musical, ou seja, cantávamos sempre 'com' as crianças.

Tentando ainda aproveitar a sensibilidade musical e o interesse das crianças pelos sons e ritmos, trouxemos um CD com algumas das músicas que até então as crianças conheciam apenas a partir das nossas cantorias na Creche. Montamos também um acervo de CD's que continha o CD completo de onde havíamos retirado as músicas que apresentadas às crianças, ampliando assim a variedade de ritmos, sonoridades e o repertório de músicas que faziam parte do cotidiano das tardes do Grupo Azul.

Foi possível observarmos a surpresa das crianças ao reconhecer as músicas que frequentemente cantávamos, mas com outra voz e com outros arranjos e sons. $\mathrm{O}$ movimento geral foi o de parar para ouvir e, em seguida, apropriar-se de algum instrumento ou objeto capaz de produzir algum som para acompanhar a música.

O nosso projeto, cada vez mais colorido com essa curiosidade das crianças, caminhou, então para ampliarmos as possibilidades de leitura de imagens dos pequenos. Durante as leituras de variados livros, sobretudo daqueles que faziam parte do acervo permanente do Grupo Azul, percebemos o interesse das crianças pelo colorido das imagens, como eram capazes de reconhecer personagens, lembravam os gestos que usávamos para contar as histórias e demonstravam, inclusive, suas preferências por determinadas histórias.

Organizamos, para contemplar esse interesse das crianças pelas imagens, uma seleção de imagens que trouxessem instrumentos musicais: "Djembe da Enorme Árvore (Artista Desconhecido); "Roda de Samba" (Carybé), "Music in Red" (Mark Buku). Diante da imagem abstrata que retratava um djembe, instrumento conhecido das crianças, o tambor do desenho é tocado com leves batidas com os dedinhos...

E, partindo da ideia do elemento que compõe os instrumentos (o djembe é um tronco de árvore cavado que ganha o couro de um dos lados...), voltamos às árvores e às folhas que as crianças nunca se cansavam de recolher para brincar. Depois de apresentarmos as fichas com as imagens, prendemos papel colorido no chão, usamos um pouco de cola e deixamos com que as crianças construíssem uma colagem com as folhas e flores que recolheram. Foi uma atividade divertida, pois os pequenos tiveram contato com a cola, material diferente e pegajoso. Algumas 
crianças gostaram de ficar tirando a cola que, quando secou nas mãos, virou uma espécie de película.

Essa atividade ainda contou com um quadro tátil, que unia a possibilidade de apreciação visual, com cores e estampas de tecidos e papéis variados, a possibilidade sonora oferecida pelo papel celofane e as diferentes texturas.

Depois de termos construídos tantas coisas com as crianças, resolvemos apresentá-las algumas das nossas atividades, partindo, sobretudo, das experiências delas com os instrumentos musicais e objetos sonoros que aprendemos a tocar e brincar juntos.

Preparamos então, uma seleção de fotos das crianças manipulando, tocando e brincando com os diferentes instrumentos e organizamos uma pequena exposição. Como as crianças se interessaram bastante pelas imagens, delas próprias e dos amigos, iniciando uma atividade de reconhecimento de si, do outro e de objetos variados que apareciam nas fotos.

Pensamos em montar uma espécie de brinquedo com as fotos, de forma que as crianças pudessem interagir com o tal brinquedo. Organizamos tudo em um bambolê formando um grande móbile, e, para incrementar o brinquedo, incluímos alguns brinquedos sonoros, chocalhos e saquinhos de tecidos com elementos olfativos (orégano, canela, cravo, folha de louro, hortelã, essência artificial de morango). As crianças, chamadas pelo toque do djembe, encontraram o móbile de bambolê e logo começaram a explorar as fotos, descobriram as fontes sonoras e, por último, interessaram-se pelos 'cheiros'.

Ao longo das atividades, outros muitos elementos eram utilizados na composição do espaço e alguns deles passaram a fazer parte do acervo cotidiano do Grupo Azul. O interesse das crianças pelos tecidos era bastante grande. As crianças usavam os tecidos para as brincadeiras de esconder e, em alguns momentos, inspirados em imagens de alguns livros oferecidos, usavam os panos como enfeites na cabeça. $\mathrm{O}$ crescente interesse por colocar tecidos na cabeça, por chapéus e pelos próprios cabelos levaram-nos a trazer chapéus de cores e modelos variados. A resposta das crianças foi tão positiva que os chapéus integraram as atividades de várias tardes no Grupo Azul...

Os pequenos do Grupo Azul acabaram apontando para as atividades do ligadas à natureza, como por exemplo, o interesse pelas folhas e flores dos pátios da 
Casinha. As crianças sinalizaram também para a presença dos pássaros. Ouvimos juntos, ao longo do ano, o canto de vários pássaros, mais frequentemente, o canto dos sabiás. E para acompanhar o canto dos pássaros tínhamos também uma música:

\section{S.J}

Uê uê, uê uá

Pinica a lima pra laranja madurá

Fui panhá laranja, laranja caiu

Eu olhei para cima, morena

\section{Sabiá fugiu}

S.J

Em geral, quando os pássaros começavam a cantar, as crianças apontavam para o ouvido. O gesto parecia querer dizer: "prestem atenção, o pássaro está cantando". Porém muitos começaram a falar ao longo do segundo semestre e juntaram ao gesto de apontar o ouvido, a palavra "escuta" ou "piu piu" (referindo-se ao pássaro). As crianças gostavam muito de ouvir os pássaros e para garantir suas visitas, uma das atividades permanentes do Grupo Azul foi a alimentação dos pássaros, feita junto com as crianças sempre que possível.

As crianças cresceram, aprenderam a engatinhar, andar, falar, e participavam das atividades do dia a dia. O final do ano se aproximou e trouxe com ele, dias de muito calor. Pensamos, então, de propor uma atividade com água para as crianças... E nos lembramos de um instrumento musical: o tambor d'água. É um tambor feito de cabaça sobre a água em que a cabaça é percutida com baquetas. As crianças até ouviram o som do tambor d'água, mas o maior atrativo foi a água mesmo e as brincadeiras que possibilitava. As cabaças do tambor logo viraram cuias para encher de água e jogar em si mesmo ou carregar água para outro lugar. Foi uma tarde divertida, em que o calor foi vencido com muita brincadeira.

O movimento das crianças em relação às suas descobertas musicais fez com que as atividades voltadas à musicalização fossem constantes na rotina vespertina do Grupo Azul. Assim, tínhamos músicas para os momentos de refeição:

\section{ร.J}

A minha boca tá com fome - ô baiana, ô ia ia

Minha barriga quer comer - ô baiana, ô ia ia

Cala boca, minha barriga - ô baiana, ô ia ia

Deixa a panela ferver - ô baiana, ô ia ia 


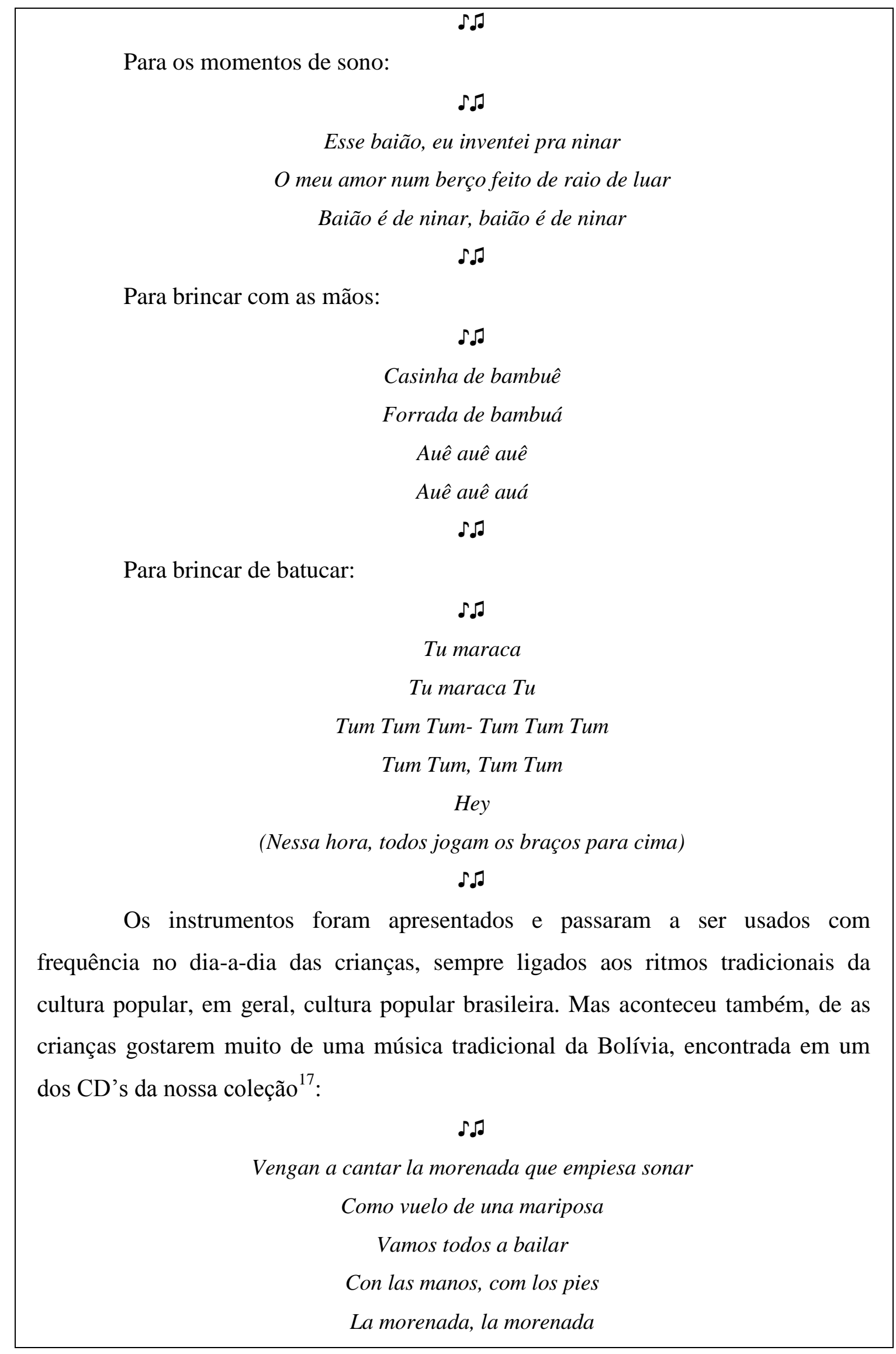

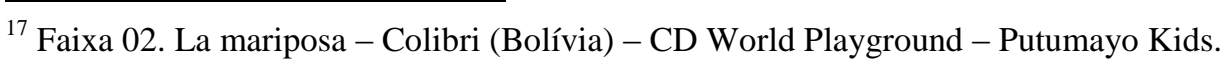




\section{ร.J}

E foi assim que desenhamos com muitas cores e muitas músicas o Projeto "Ritmos Coloridos: Grupo Azul em Sons e Cores", nas tardes de 2012. Cantamos juntos muitas canções, tocamos juntos variados instrumentos e brincamos juntos com diferentes materiais... Construímos juntos uma história para Grupo Azul em 2012.

Relatório de Grupo Azul - 2012 